
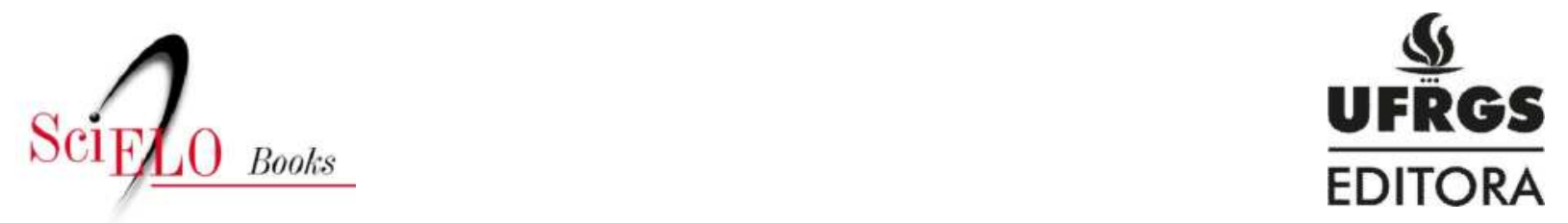

\title{
Desvendando a história da África
}

\author{
José Rivair Macedo (org.)
}

\section{SciELO Books / SciELO Livros / SciELO Libros}

MACEDO, JR., org. Desvendando a história da África [online]. Porto Alegre: Editora da UFRGS, 2008. Diversidades series, 240 p. ISBN 978-85-386-0383-2. Available from: doi:

10.7476/9788538603832. Also available in ePUB from:

http://books.scielo.org/id/yf4cf/epub/macedo-9788538603832.epub.

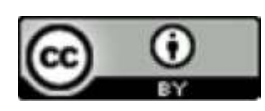

All the contents of this work, except where otherwise noted, is licensed under a Creative Commons Attribution 4.0 International license.

Todo o conteúdo deste trabalho, exceto quando houver ressalva, é publicado sob a licença Creative Commons Atribição $\underline{4.0}$.

Todo el contenido de esta obra, excepto donde se indique lo contrario, está bajo licencia de la licencia $\underline{\text { Creative Commons }}$ Reconocimento 4.0. 
Desvendando a
história da África 


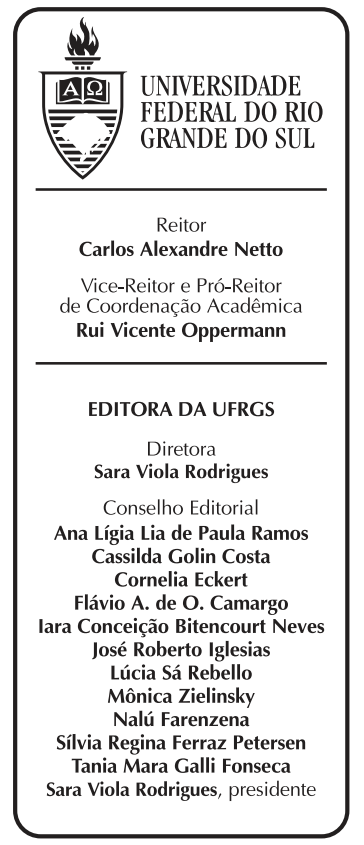




\section{Desvendando a história da África}

José Rivair Macedo

Organizador

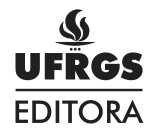


(C) dos autores

$1^{a}$ edição: 2008

Direitos reservados desta edição:

Universidade Federal do Rio Grande do Sul

Capa e editoração eletrônica: Ivan Vieira

Revisão: Luís Augusto Junges Lopes - Press Revisão

D478 Desvendando a história da África / organizado por José Rivair Macedo. - Porto Alegre:

Editora da UFRGS, 2008.

240 p. : il. ; $14 \times 21 \mathrm{~cm}$

(Série Diversidades. Linha Editorial Etnicidade, Identidade e Territorialidade).

Programa de Extensão Educação Anti-Racista no Cotidiano Escolar e Acadêmico/UFRGS.

Inclui referências.

1. Educação. 2. Educação das relações étnico-raciais. 3. Continente africano - Geografia. 4. Civilizações africanas - Historiografia. 5. África - História. 6. Sudão Ocidental - Comércio. 7. Sudão Ocidental - Religião. 8. Sudão Ocidental - Escravidão. 9. Sociedades africanas - Colonianismo. 10. África - Independência 11. Apartheid. 12. Angola - Independência 13. Diáspora africana. 14. História da África Ensino. I. Macedo, José Rivair. II. Título. III. Série.

CDU 96

$37: 323.118$

CIP-Brasil. Dados Internacionais de Catalogação na Publicação.

(Jaqueline Trombin- Bibliotecária responsável CRB10/979)

ISBN 978-85-386-0019-0 


\section{PREFÁCIO}

Existem tarefas que são prazerosas e difíceis. Esta é uma dessas, prazerosa pela honra e difícil pela responsabilidade em prefaciar os resultados do trabalho dedicado de toda equipe do Departamento de Educação e Desenvolvimento Social da Pró-Reitoria de Extensão da UFRGS e de seus associados de outras instituições.

Esta publicação é fruto da confluência de vários fatores que passaram a contar com o porto seguro oferecido pela Lei $n^{\circ} 10.639$, de 2003, que institucionalizou o estudo integral da História do Brasil e o reconhecimento do papel primordial dos africanos e de seus descendentes na construção da civilização brasileira. Sua origem é tão ampla e diversificada como os trabalhos aqui apresentados. Todos eles norteados pela vontade de trabalhar a História da África como objeto direto de conhecimento e pela luta pela verdade histórica e contra os preconceitos eurocêntricos.

Estão de parabéns os ex-alunos da UFRGS que pioneiramente, aqui no Estado, orientaram-se para a temática; os pesquisadores, professores e organizadores que aceitaram o risco de abrir um novo campo de trabalho a institucionalizá-lo; os historiadores e professores que, de forma pioneira e isolada, 'remaram contra a maré'; os professores de ascendência africana no ensino fundamental e médio com sua luta diuturna contra todas as adversidades; a Faculdade PortoAlegrense e a Universidade La Salle pelo pioneirismo em cursos de especialização sobre a temática; e, principalmente, o Departamento de Educação e Desenvolvimento Social da Pró-Reitoria de Extensão da UFRGS pela realização do curso de extensão "Desvendando a História da África", e por esta publicação.

O trabalho orientou-se para proporcionar uma visão ampla e íntegra da África e de sua diversidade, ressaltando a contribuição inalienável das suas populações para a história da humanidade, do Brasil e para nossa formação como seres humanos. 
Como congregação de esforços é o primeiro balbuciar, o engatinhar de uma experiência (o curso "Desvendando a História da África") que, tenho a convicção, resultará em forte tendência de produção interdisciplinar para o conhecimento em todas as suas dimensões.

Temos aqui o início de uma longa jornada que exige a ruptura de paradigmas consagrados, firmeza na determinação com o compromisso do conhecimento e da verdade, cuja aquisição é dinâmica, contraditória e progressiva.

Fruto de vontades e de experiências marcadas pela necessidade, este livro é esboço de um mapa para orientação e não um dogma. Ele disponibiliza a contribuição dos rio-grandenses nativos e adotivos para a construção de um Brasil mais verdadeiro, justo e equânime. Como resultado da conjugação coletiva de esforços, abre decisivamente um campo novo ... brasileiro.

Aos leitores, bom proveito e que sua utilização sirva para aprofundar a reconstruir nossa história.

Aos amigos (colegas e alunos), que me proporcionaram a vivência e me honraram com o prefácio, meus agradecimentos na expectativa de não decepcioná-los.

Luiz Dario Teixeira Ribeiro Depto. de História - UFRGS 


\section{Sumário}

1 - Introdução: o meio geográfico e sua influência no continente africano /9

Felippe Jorge Kopanakis Pacheco

2 - Antigas civilizações africanas:

historiografia e evidências documentais / 13

José Rivair Macedo

3 - África: uma história a ser reescrita / 29

Jorge Eurébio Assumpsão

4 - O comércio transaariano e

os Estados do Sudão Ocidental: séculos VIII-XVI / 45

Diego Souza Marques

5 - Religião, poder e sincretismo:

o Islã no Império Songai (séculos XV-XVI) / 57

Bárbara Macagnan Lopes e Leonardo Veiga Guarnieri

6 - A escravidão entre os povos do

Sudão Ocidental: séculos VII-XVI / 69

Diego Schwalb Zanoto

7 - Viajantes brancos na África negra do século XV / 85

Eder da Silveira e Silvio Marcus de Souza Correa

8 - Os Estados africanos nos séculos XVI-XVIII:

desenvolvimento desigual na África Ocidental / 97

André Luiz Reis da Silva

9 - As sociedades africanas e o colonialismo / 111

Tania Maria Seggiaro Chagastelles

10 - Independência, marginalização

e reafirmação da África (1957-2007) / 123

Paulo Gilberto Fagundes Visentini 
11 - Apartheid: apogeu e crise do regime racista na África do Sul (1948-1994) / 139

Analúcia Danilevicz, Pereira

12 - Angola: independência, conflito e normalização / 159

Joveta Jose

13 - Diáspora africana: paraíso perdido ou terra prometida / 181 José Antônio dos Santos

14 - A história africana nas salas de aula: diálogos

e silêncios entre a Lei $n^{\circ} \mathbf{1 0 . 6 3 9 / 0 3}$ e os especialistas / 195

Anderson Ribeiro Oliva

15 - O ensino de História da África:

experiências a partir da sala de aula /211

Marisa Antunes Laureano

Outras referências sobre história africana / 223

Autores / 233 


\section{1 \\ INTRODUÇÃO: \\ O MEIO GEOGRÁFICO E SUA INFLUÊNCIA \\ NO CONTINENTE AFRICANO}

\section{Felippe Jorge Kopanakis Pacheco}

O continente africano é o espaço geográfico onde a diversidade, em todos os sentidos, mais se faz presente, seja nos aspectos físico-morfológicos, seja na cultura, nas etnias que habitam seu espaço, na vegetação. É necessário que olhemos o continente africano com outros olhos, não com a visão com a qual nos acostumamos. A visão que temos é de que no continente africano só há fome e miséria, bichos ferozes e Tarzan e Chita.

Para começar, é preciso que deixemos de utilizar a palavra "África" quando queremos dizer algo em relação ao continente. Se existem várias "Áfricas”, unidas e distantes em função da complexa diversidade existente, faz-se necessário também nos utilizarmos de uma nova nomenclatura. Em minhas pesquisas e trabalhos cartográficos, adotei o termo "Continente Africano".

O Continente Africano é o berço da humanidade. De lá partiram os primeiros homo sapiens para se espalhar pelo mundo. É necessário lembrar que, na Era Quaternária, cerca de 10 milhões de anos atrás, a configuração do planeta era de períodos gelados e glaciação, que causou enormes transformações no clima, na estrutura morfológica e, logicamente, na vida animal e vegetal, período este que coincide com o surgimento do homem primitivo.

Observando-se o mapa de vegetação, podemos notar a diversidade a partir da linha do Equador. O clima acompanha a sucessão das faixas da cobertura vegetal do continente africano. Encontramos desde florestas tropicais, florestas deciduais de savana de árvores, de 
gramíneas, estepe, semideserto, gramíneas de montanhas, vegetação do tipo mediterrânea e florestas de montanhas, dominadas pela tundra. Ao norte e para o sul do Equador, a influência das chuvas e a diminuição da pluviosidade, conforme as latitudes vão aumentado, se constituem em fator decisivo para o clima do continente.

Uma das grandes e mais marcantes características geográficas do Continente Africano são as bordas altas e as terras rebaixadas ao centro. Esse fator é responsável por cerca de 53\% dos rios do continente desaguarem em terras interiores.

Ao norte do continente, a paisagem é dominada pelo deserto do Saara, de leste a oeste. Na região subsaariana, o semideserto, vindo logo após a floresta decidual de gramíneas a estepe, formam-se longas faixas dominando o cenário desde a costa do Atlântico até o Mar Vermelho. Nas bacias do Níger, Senegal, baixo Nilo e do Congo, abre-se a grande floresta decidual de savana de árvores, e a imensa Floresta Tropical, regiões dos povos mais conhecidos do continente e que tiveram influência direta na formação do povo brasileiro.

A savana toma conta de grande parte da paisagem do continente também ao sul do Equador, e em manchas nas terras de maior altitude, encontra-se a Tundra. No extremo sul do continente, vegetação do tipo mediterrânea ocupa espaço na paisagem com semidesertos e o deserto da Namíbia, a oeste, e com a savana e a estepe, a leste.

Mas qual é o papel que o meio geográfico desempenhou na história do Continente Africano? O primeiro deles foi o isolamento geográfico de seu interior. Protegido por dois oceanos a leste e oeste, um imenso e fastigante deserto ao norte e um litoral totalmente inóspito e de difícil acesso dificultaram, durante séculos, a penetração de outros povos para o seu interior, mantendo o continente praticamente isolado.

A leste, o Oceano Índico representou o elo comercial das populações com a Península Arábica e o Oriente. A oeste, o Oceano Atlântico, principalmente a partir do século XV, abriu as portas do continente para a chegada e penetração do homem europeu. Mesmo 
assim, o europeu levou praticamente quase duzentos anos para efetivamente colocar os pés no interior do continente.

Seu interior possuía imensos espaços disponíveis. A sua baixa densidade populacional resultou na pouca valorização do solo, gerando, assim, uma conseqüência econômica, social e política. O trabalho humano era muito mais valorizado do que a terra.

Especialmente em relação ao grande deserto do Saara, algumas características particulares tiveram influência decisiva na história do Continente Africano. As alterações climáticas decorrentes dos períodos de glaciação e aquecimento provocaram a dispersão das populações pelo continente. A mudança do regime hídrico levou enormes contingentes populacionais a se deslocarem pelos espaços internos. Isso gerou a miscigenação de povos Etipóides e Afro-Mediterrâneos com populações de negros do tipo Sudanês.

O deserto do Saara desempenha uma importante via de comunicação e comércio entre o Continente Africano e o Mediterrâneo, a Península Arábica e o Oriente próximo, e constitui-se na porta de entrada do mundo islâmico nas regiões litorâneas e interiores do continente. Limitou a penetração e entrada de influências européias na arquitetura, na agricultura, no artesanato e na cultura. O Saara teve o papel fundamental de manter o interior do continente isolado durante vários séculos.

Em outras partes do continente africano, o solo, a chuva, o calor, a falta de água, as imensas florestas e a fauna exercem papel vital na história dos povos africanos, que, ao mesmo tempo que propiciaram aos povos se desenvolverem, constituíram obstáculos naturais à entrada do europeu e à fixação humana. A secura e a violência das chuvas tropicais mantiveram a pobreza do solo e dificultaram a elaboração do húmus.

A escassez de água gera decisiva influência na vida migratória dos povos do Continente Africano. No centro do continente, uma imensa e gigantesca floresta densa, úmida e alta dificulta a penetração e a fixação do homem. 
Por outro lado, a exuberante riqueza nos três reinos naturais foi, e ainda o é, motivo de cobiça ao continente. No subsolo, encontramse as maiores riquezas minerais do globo terrestre, como os diamantes, o ouro, ferro e variados tipos de rochas e argila. O reino vegetal sempre foi responsável por garantir aos povos os recursos alimentares necessários para a sobrevivência humana, suas moradias e vestimentas, o mesmo ocorrendo com o reino animal, com abundantes reservas de caça e peixes e outros animais à disposição. 


\section{ANTIGAS CIVILIZAÇÕES AFRICANAS: HISTORIOGRAFIA E EVIDÊENCIAS DOCUMENTAIS}

\section{José Rivair Macedo}

Os estudos africanos nasceram no princípio do século XX e se afirmaram no decurso dos anos 1960, junto com a formação dos Estados africanos contemporâneos. Tal qual o Brasil, aqueles países também são jovens nações pós-coloniais e enfrentam limitações similares às que enfrentamos para a construção dos campos do conhecimento científico.

De outro lado, a África é um continente imenso, que há milênios abriga diferentes povos e culturas. Parece-nos sumamente injusto periodizar a sua história dividindo-a, como se costuma fazer, em três períodos: pré-colonial (até o século XIX), colonial (até meados do século XX) e independente (até o presente). Adotar essa periodização significa continuar a olhar para o passado africano com os olhos dos colonizadores, significa considerar a colonização e o imperialismo europeu o elemento central dos processos históricos que ali se desenvolveram. É preciso, na medida do possível, olhar para a África com o olhar dos africanos, construir o conhecimento histórico e narrar a História a partir de uma perspectiva propriamente africana.

Mas a tarefa não é simples. Ao questionar a periodização tripartite, corremos o risco de cair numa outra cilada. Como nos lembra o historiador congolês Elikia M'Bokolo, a substituição da expressão África Pré-colonial por Africa tradicional pode também acarretar prejuízos na medida em que, no Ocidente, a idéia de tradição costuma ser identificada com imobilismo, conservadorismo, estagnação, opondose ao dinamismo, ao avanço e à transformação inerentes à idéia da 
modernidade (M’Bokolo, 2003). Por isso, em vez desses rótulos, o melhor mesmo é falar simplesmente de História africana, sem complementos ou adjetivos.

\section{Colonialismo e Eurocentrismo}

Quanto aos enfoques predominantes e às condições pelas quais o conhecimento histórico do continente africano tem sido elaborado, convém levar em conta a existência de pelo menos três tendências principais de abordagem, tais quais foram apresentadas pelo historiador guineense Carlos Lopes, em seu importante estudo $A$ pirâmide invertida - bistoriografia africana feita por africanos (1994).

A primeira delas coincidiu com o período da dominação colonial européia e recebe o nome de "corrente da inferioridade africana". Os traços gerais que a caracterizam aparecem em obras escritas em sua maior parte na primeira metade do século XX. Nelas, prevalece a idéia de que os povos africanos, por não conhecerem a escrita (o que é, naturalmente, uma falácia), não teriam história própria.

Da Société des Africanistes, fundada em Paris em 1930, participavam antropólogos (Paul Rivet, Lévy-Bruhl, Marcel Mauss, Marcel Griaule) e lingüistas (Marcel Cohen, Antoine Meillet), mas também pessoas conhecidas afetuosamente pelos demais membros como "velhos africanos", quer dizer, administradores, funcionários do governo ou militares que, durante muito tempo, tinham servido nas colônias, ali adquirindo experiência e conhecimento. O primeiro presidente da entidade, o General Henri Gouraud, era capitão no Sudão francês em 1898, quando se destacou na repressão da revolta ocorrida na Guiné e na prisão do líder Samory Touré. O único africano autêntico na associação era Léon Mba, que trinta anos mais tarde viria a ser o primeiro presidente da República do Gabão.

Os primeiros africanistas saíram dos postos do governo colonial. Não admira que em suas obras tenham se esforçado por desco- 
brir, na origem dos povos e Estados que estudavam, a contribuição de civilizações mais “avançadas”, não-africanas. A essas explicações, que localizam fora do continente as origens de suas instituições, costumes e tecnologias, dá-se o nome de "difusionismo".

Foi o que aconteceu com o importante etnólogo Maurice Delafosse (1870-1926), lembrado como o "pai" dos africanistas franceses, que respondia pelos assuntos culturais africanos na administração do Sudão. Ele estudou em profundidade a formação cultural e histórica dos povos sudaneses, e embora simpático a esses povos, não deixou de cair em armadilhas. Autor da monumental HautSénégal-Niger, de 1912, na qual aparecem pela primeira vez articuladas as histórias dos grandes estados das savanas da África Ocidental, Delafosse não podia admitir que, no século IV da era cristã, tivesse existido uma civilização negra do porte do Reino de Gana. Em sua opinião, a primeira dinastia de governantes de Gana teria sido constituída por brancos - judeus-sírios que para lá emigraram, provenientes de Cartago. Quanto ao "pai" da história sul-africana, G. Mc Call Theal, sua monumental History of South Africa, publicada entre 1888-1919 em 5 volumes, celebra o triunfo do colonialismo branco e britânico, e é a primeira a propor a idéia, amplamente utilizada durante o regime do Apartheid, da chegada simultânea de brancos e negros na África austral.

Não é incomum encontrarmos nos autores europeus ou norteamericanos desse período expressões como "povos sem História", "povos selvagens" ou "povos infantis". Subjacente a esses lugarescomuns perpassa a habitual oposição entre o "selvagem" e o "colonizador", entre a "civilização" e a "barbárie", o continente africano sendo encarado como um "fardo do homem branco". Para compreendermos as condições que explicam tal tendência, deveremos lembrar que ela encontrou suporte em um discurso elaborado a partir das teorias do "racismo científico", então amplamente aceitas nos meios acadêmicos. Tal ponto de vista aparece de modo muito explícito nas palavras de Philip Mitchell, que nos anos 1950 ocupou o cargo de 
governador inglês do Quênia. Para ele, a colonização era acompanhada de uma missão civilizadora:

O Ocidente passou a ter sob seu controle milhões de pessoas que nunca haviam inventado ou adotado qualquer espécie de alfabeto ou, até mesmo, de escrita hieroglífica. Os africanos não possuíam números, calendários nem medidas de comprimento, volume e peso. Entre eles não havia moeda corrente, e o comércio exterior limitava-se ao marfim e ao tráfico de escravos. Além disso, desconheciam o arado e a roda, utilizando como meio de transporte apenas rústicas canoas. Essa gente não havia construído coisa alguma em que tivessem empregado materiais mais duráveis do que o barro, a madeira e o sapé... O processo que hoje chamam de 'colonialismo' tem sido, acima de qualquer dúvida, uma das forças mais efetivas, benéficas e desinteressadas já trazidas para a África e utilizadas em seu favor ao longo de toda a sua história. (Citado em África Tropical. São Paulo: Ed. Abril, 1973, p. 709).

\section{Afrocentrismo e Tendências Recentes}

A segunda tendência de abordagem, predominante principalmente entre os anos 1960-1980, nasceu no bojo do processo de descolonização e construção dos Estados contemporâneos africanos. Por oposição à tendência anterior, é por vezes chamada de "corrente da superioridade africana", e na África Ocidental teve como principais defensores Cheikh Anta Diop, Théophile Obenga, Aboubacry Moussa Lam e Kapet De Bana. Nesse caso, tratava-se de recuperar a História dos povos africanos e refletir sobre a identidade do continente, identificar os motores próprios de sua história e, em certos casos, inverter a posição de subordinação até então preponderante, localizando na África a matriz civilizacional de outros povos.

Cheikh Anta Diop (1923-1986) é considerado o "pai" do panafricanismo e o mais influente intelectual africano do século XX. Teve em sua formação mestres do porte do filósofo Gaston Bachelard, do arqueólogo André Leroi-Gourhan e do historiador André Aymard, além de especialização em física nuclear no College de France. Todavia, distanciava-se dos franceses ao propor com ênfase a idéia da anterioridade das civilizações negras e a necessidade 
de uma identidade racial e cultural dos povos negros, propostas defendidas, sobretudo, nos livros Nations nègres et culture (1954) e L'unité culturelle de l'Afrique noire (1960).

Noutra obra fundamental, L'Afrique noire pré-coloniale, apresenta um estudo histórico-sociológico da formação dos sistemas políticos e sociais da África Ocidental e da Europa, da Antigüidade aos tempos modernos, estabelecendo paralelos e comparações em que a África se destaca por sua originalidade e autonomia. Eis uma passagem:

Os africanos jamais viveram a experiência de uma república laica, embora seus regimes políticos tenham sido quase sempre democráticos, com poderes equilibrados. Por isto é que todo africano é sem saber um aristocrático, como todo burguês francês o era antes da Revolução. Os reflexos profundos do africano atual ligam-se em primeiro lugar a um regime monárquico e não a um regime republicano. Tanto o rico quanto o pobre, o camponês e o citadino, sonham ser um pequeno ou grande senhor e não um pequeno ou grande burguês. A qualidade dos gestos e atitudes, a maneira de abordar as coisas, seja qual for a casta, é senhorial, aristocrática, por oposição à 'mesquinharia' burguesa. No que tange ao comportamento, toda uma revolução separa a consciência africana da ocidental. Estas seqüelas de aristocratismo não teriam desaparecido nem mesmo se o africano, no decurso de sua história, tivesse assumido ele próprio seu destino nos quadros de um regime republicano. E a colonização ocidental republicana não pôde modificar este traço (Diop, 1987, p. 74).

Para Diop, o Egito antigo era povoado por negros, e a matriz egípcia acabou sendo emprestada aos povos do Egeu e do Mediterrâneo, mas também ao Sudão nilótico da civilização de Meroé e da Etiópia, e mesmo aos estados da África Ocidental, como o reino de Gana, onde se podiam encontrar vestígios de técnicas metalúrgicas, de instituições de governo e similaridades lingüísticas. Recolocado em seu devido lugar desde os primórdios da História da humanidade, o continente africano tornava-se assim um centro de irradiação civilizacional. Seus discípulos tiveram ativa participação na redação da História Geral da África e na decifração da escrita meroítica em 1974, atuando junto ao Institut Fondamental de l'Afrique Noire (IFAN) da Universidade de Dakar, que, na atualidade, recebe o nome de Universidade Cheikh Anta Diop de Dakar, em sua homenagem. 
$\mathrm{Na}$ África do Sul, a reavaliação historiográfica girou em torno da luta anti-apartheid, quando eruditos como Hosea Jaffé (sob o pseudônimo de Mnguni) e a missionária Dora Taylor (sob o pseudônimo de Nosipho Majeke) colocaram em questão a legitimidade da colonização inglesa. Quanto à África Oriental, o nascimento dos estudos especializados em História da África deve muito a John Fage e Kenneth Ingham, que no final da década de 1950 lecionaram nos colégios de Legon, Ibadan e Makerere. A disciplina tornou-se também obrigatória no Colégio Universitário de Nairobi em 1964, sendo ministrada por B. A. Ogot, e no Colégio de Dar es Salaam, por Terence Ranger.

Em um congresso internacional para a escritura da História da África, patrocinado pelo governo da Tanzânia em 1965, o ponto central do programa era a busca da especificidade e autonomia da experiência histórica africana. Isso fica bem explicitado desde a introdução do evento, quando o historiador Engelbert Mveng, da Universidade Federal de Yaoundé, Camarões, afirmava:

A África tem o dever de afirmar a autenticidade de seu passado, não em virtude da imagem criada pelos observadores estrangeiros, mas em virtude da verdade daquilo que foi vivido, experimentado e expresso por ela mesma (Mveng, 1971, p. 17).

Paralelamente, com o apoio de instituições internacionais, os estudos africanos ganharam importantes suportes de investigação. Em 1960, aparecia o mais respeitado periódico científico reservado aos estudos de africanismo até a atualidade, o Journal of African History. Em 1972, Joseph Ki-Zerbo escreveu uma consagrada síntese histórica sobre o continente, a Histoire de l'Afrique Noire (História da África negra), traduzida para diversas línguas e tida como um clássico da historiografia africana. Data dos anos 1970-1980 a elaboração de duas significativas obras de referência, a coleção inglesa The Cambridge History of Africa, em 8 volumes, dirigida por Roland Oliver e John Fage, e, sobretudo, a excepcional Histoire Générale de l'Afrique, em 8 volumes, produzida por um comitê de investigadores africanos e não-africa- 
nos com o patrocínio da UNESCO - obra rigorosa e objetiva, lastreada em pressupostos teórico-metodológicos sofisticados, submetida ao exame crítico dos mais destacados africanistas.

A terceira tendência de abordagem ganhou corpo durante os anos 1990 e resulta da produção de conhecimento de intelectuais formados no próprio continente africano. Suas interpretações pretendem superar as mazelas do "eurocentrismo" e do "afrocentrismo". Preocupa-se com o pluralismo, com a busca da especificidade, da originalidade e diversidade das realidades históricas africanas, e com a atualização das técnicas e dos métodos de pesquisa (Kipre, s.d.). De modo um tanto esquemático, pode-se dizer que a melhor expressão dessa perspectiva de análise encontra-se na síntese histórica proposta em 2003-2004 por Elikia M'Bokolo, do Centro de Estudos Africanos da École des Hautes Études en Sciences Sociales, Paris, intitulada Afrique noire. Histoire et civilisations (África Negra. História e civilizações), na qual as datas e os eventos cedem lugar aos conceitos e na qual são estabelecidas tipologias das formações estatais e sociais levando em conta a variedade de povos e culturas, identificando as interferências externas (muçulmanas, cristãs) e sua africanização.

Nessa perspectiva de estudo, a ênfase não está mais numa suposta "identidade africana", como se a África comportasse uma realidade homogênea. O que se procura é identificar as várias Áfricas, considerando a diversidade ambiental (a África mediterrânica, saariana, subsaariana, das savanas, da floresta) e a diversidade étnico-cultural (a África muçulmana do Egito e Magreb, a África muçulmana sudanesa, a África Oriental da cultura swahili, a África malgaxe de Madagascar, a África banto). Nessas operações, interessam tanto os grandes quanto os pequenos Estados, as formações sociais predominantes e as que são minoritárias e mesmo específicas de um povo.

O objetivo é o estabelecimento de um conhecimento que respeite as particularidades, um conhecimento menos preocupado em detectar traços gerais que, no final das contas, é onde se alojam os prejulgamentos e os preconceitos. Diversidade de abordagens e di- 
versidade de escalas de análise, eis as orientações principais da nova geração de africanistas. Nas palavras de um deles:

A África é parte integrante do mundo atlântico, do mundo mediterrâneo, dos espaços árabe, indiano e indonésio. Não é uma 'área cultural', mas um espaço continental construído historicamente, quer dizer, econômica, social, política e culturalmente (Chrétien, 2003, p. 17).

\section{Testemunhos Documentais}

$\mathrm{Na}$ medida em que as pesquisas dos africanistas avançaram, muitos mitos e falácias caíram por terra. O primeiro lugar-comum abandonado foi o da impossibilidade de se conhecer o passado africano pela falta de evidências históricas, de testemunhos documentais. Está mais do que provada a existência de documentação escrita e vestígios arqueológicos os mais variados, e está mais do que comprovada a importância da tradição oral na recuperação da memória dos reinos, das linhagens, dos fundadores das nações africanas.

É claro que a quantidade da documentação escrita aumentou após o século XVI, com os registros de comerciantes, exploradores e viajantes cristãos europeus (Ekanza, s.d.). Nessa categoria, as informações fornecidas por Duarte Lopes, e copiadas por Filippo Pigafeta em 1591, em A Relação do Reino do Congo, mostram-se imprescindíveis para o conhecimento da constituição política do Reino do Congo e do Reino de Angola, suas províncias e suas atividades econômicas, sua organização militar, técnicas de guerra, e a gradual interferência dos portugueses no decurso do século XVI.

Outra fonte primária de excepcional valor é o relato de viagem do médico inglês Mungo Park, que entre 1795 e 1797 percorreu a África Ocidental, da desembocadura do Rio Gâmbia até a Curva do Rio Niger. Em Travels in the interior districts of Africa performed under the direction and patronage of the African Association, ele nos deixou um relato muito vivo e original da vida cotidiana dos povos islamizados do litoral, do deserto do Sael e da savana, onde prevalecem a objetivida- 
de e, em certas passagens, a admiração por grandes reinos e cidades como Bambara, Silla e Tombuctu.

Convém não desprezar o significado do aporte dos escritores muçulmanos (africanos ou não), que nos deixaram crônicas, roteiros de viagens, obras geográficas, informações comerciais sobre os povos africanos com quem estabeleceram contato muito antes dos cristãos. Em meados dos anos 1970, o francês Joseph Cuocq reuniu uma quantidade considerável de textos sobre a África Ocidental (Gana, Mali, Kanem-Bornu, Songai) redigidos por escritores muçulmanos anteriores ao século XVI. Os comentários de grandes eruditos como Al Bakri e Al Idrisi do século XII, Ibn Battuta, Al Umari e Ibn Khaldun do século XIV contêm informações preciosas sobre as instituições sociais e os costumes dos africanos que viveram acima e abaixo do Saara (Cuocq, 1975). Mais recentemente, o africanista brasileiro Paulo Fernando de Moraes Farias, do Centre of West African Studies da Universidade de Birmingham, lançou nova luz nos estudos dos povos saelianos ao publicar mais de 250 inscrições em árabe ou em tifinagh, a escrita tuaregue, feitas em túmulos, epitáfios, grafites rupestres, produzidas nas proximidades da Curva do Níger, no Mali (Triaud, 2006).

Além disso, há que se levar em conta a existência de documentação narrativa escrita nas cidades mais importantes dos antigos Estados do Mali e do Songai, sobretudo nas cidades de Djenne e Tombuctu, que viram nascer desde pelo menos o século XIV núcleos de conhecimento erudito em torno das madrasas ${ }^{1}$ de suas mesquitas. Desde 2003, com o apoio de organismos internacionais, mais de 15 mil manuscritos escritos em árabe ou em dialeto fula foram catalogados e começaram a ser preservados na Biblioteca do Instituto Ahmed Baba, em Tombuctu. Naquele mesmo ano, grupos de técnicos malianos passaram a realizar estágio no Arquivo Nacional e na Biblioteca Nacional da África do Sul com a intenção de estudar os procedimentos metodológicos adequados para a conservação de manuscri-

\footnotetext{
${ }^{1}$ Escola de conhecimento, relacionada ao ensinamento do Alcorão e da tradição muçulmana.
} 
tos e, em 2004, peritos sul-africanos foram enviados a Tombuctu para reproduzir e fotografar os manuscritos (Farias, 2007).

Da escola de conhecimento criada em torno da Mesquita de Sankoré, em Tombuctu, nos restaram duas fontes documentais de extraordinária importância: a crônica de autoria do sábio Mahmud Kati, composta no fim do século XVI, intitulada Tarikh al-Fattash, e a crônica concluída em meados do século XVII pelo sábio Al Sadi, intitulada Tarikh al-Sudan. Trata-se de testemunhos privilegiados para se conhecer a história dos impérios sudaneses, dos povos englobados por aqueles impérios, e sua participação no comércio transaariano. A primeira tradução do árabe para o francês da obra de Al Sadi foi publicada entre os anos 1898-1900 pelo arabista Octave Houdas, com o título Tarik es-Soudan. Atualmente, essa tradução encontra-se disponível, integralmente digitalizada, no sítio da Biblioteca Nacional de Paris (www.gallica.fr).

Quanto aos vestígios materiais, houve nas últimas décadas uma decisiva mudança de orientação. As prospecções deixaram de ser feitas em busca de tesouros ou objetos exóticos, e passaram a ter objetivos científicos melhor estabelecidos. $\mathrm{Na}$ história das pesquisas realizadas na África, o episódio mais dramático parece ter sido o da exploração arqueológica das ruínas do Grande Zimbábue, situadas nas proximidades dos rios Zambeze e Limpopo, na atual República do Zimbábue.

Ocupada primeiramente por portugueses, e depois pelos ingleses, a região recebeu durante o período colonial o nome de Rodésia em homenagem a Cecil Rhodes, poderoso empresário e administrador que promoveu sua incorporação e exploração. Em 1895, a Rhodesian Ancient Ruins Company recebeu do governo inglês a concessão de exclusividade na exploração mineral e também das ruínas, chamadas zimbabwes - termo que na língua local, o xona, significa "muralhas de pedra". Preocupados mais com o valor comercial dos artefatos de ouro do que com a preservação das descobertas, os engenheiros e operários da companhia provocaram tal depredação que as formas originais do sítio arqueológico perderam-se para sempre. 
Não obstante, as impressionantes construções de pedra despertaram curiosidade nos eruditos europeus, desafiando seu conhecimento e estimulando sua imaginação. Quando, em 1874, as colossais muralhas de pedra foram localizadas pelo naturalista alemão Karl Mauch, ele pensou ter encontrado a prova material da existência histórica do antigo reino da Rainha de Sabá, citada no Antigo Testamento. Algum tempo depois, em 1892, no livro Ruined cities of Mashonaland, o pesquisador Theodore Bent apresentava outra explicação, defendendo a hipótese de que se tratava de uma construção feita pelos povos fenícios. Foi preciso esperar até 1931 para que, no livro The zimbabwe culture, Gertrude Caton-Thompson provasse, de modo irrefutável, que aquela era uma obra produzida pelos bantos, embora seu relatório tenha sido muito criticado pela comunidade científica inglesa (Gonçalves, 2004).

Desde os anos 1970 é possível observar uma significativa mudança de orientação das pesquisas arqueológicas realizadas em solo africano. Até ali prevaleciam projetos de grande envergadura desenvolvidos por pesquisadores estrangeiros, em busca dos vestígios materiais de monumentos produzidos pelas antigas civilizações africanas. Desde a exploração predatória que descaracterizou o sítio arqueológico original do Grande Zimbábue até as pesquisas realizadas nos anos 1960 pelo primeiro professor de arqueologia da Universidade de Dakar, o francês Raymond Mauny, para encontrar as fundações em pedra de mesquitas e palácios dos tempos do reino de Gana, buscava-se localizar as fundações de fortalezas, habitações, templos religiosos (Mauny, 1970).

Nas últimas décadas, o interesse dos pesquisadores mudou de rumo, e o foco passou a ser os dados da cultura material, da produção cultural e econômica. Persistem trabalhos de investigação direcionados a monumentos, como as escavações realizadas entre 1999 e 2003 por arqueólogos franceses, sob a coordenação de Stéphanes Pradines, com a finalidade de localizar e estudar as fortificações, os palácios e as mesquitas dos séculos XIV e XV da cidade afro-mu- 
çulmana de Gedi, situada na atual República do Quênia (Pradines, 2003). Mas outros projetos pretendem detectar, por exemplo, as condições pelas quais se desenvolveram as técnicas da metalurgia e da cerâmica na região de Burkina Fasso, Congo e em Angola, ou as formas pelas quais se realizaram transações comerciais e a circulação de moedas (manilhas e cruzetas) no território banto (Rodrigues, 2002).

Por fim, resta considerar o valor e a contribuição decisiva do uso da tradição oral. Isso se pode verificar desde a publicação da coleção Histoire générale de l'Afrique, na qual os elementos da tradição oral serviram não apenas para corroborar dados considerados obscuros nas referências escritas, mas, em certos casos, constituíram o pilar de sustentação das origens de reinos e dinastias, como no caso dos mossis ou dos povos da região dos Grandes Lagos. Depois das reflexões de Jan Vansina, parece indiscutível o fato de que, sem a incorporação dos dados da tradição oral de inúmeros povos africanos, a imagem que teremos de seu passado estará despida de seu traço mais singular.

Com efeito, aquelas foram sociedades eminentemente orais, nas quais os dados da tradição e da memória ocupam uma posição muito mais importante do que consideramos em nossa própria cultura e sociedade. A palavra encerra o mistério, a sacralidade, o valor moral e a norma social. A memória dos antepassados continua a ser preservada nas palavras e nos conselhos dos domas, velhos iniciados, portadores de conhecimentos guardados e transmitidos através de linhagens, de geração a geração. Esta memória é difundida pela palavra dos griôs, os contadores de histórias. Como nos ensina Amadou Hampaté Bâ, ele próprio um erudito à moda ocidental e um doma à moda sudanesa:

Dentro da tradição oral, o espiritual e o material não estão dissociados. Ao passar do esotérico para o exotérico, a tradição oral consegue colocar-se ao alcance dos homens, falar-lhes de acordo com o entendimento humano, revelar-se de acordo com as aptidões humanas. Ela é ao mesmo tempo religião, conhecimento, ciência natural, iniciação à arte, história, divertimento e 
recreação, uma vez que todo pormenor sempre nos permite remontar à Unidade primordial (Hampaté Bâ, 1984, p. 183.).

Eis um breve panorama das interpretações que se fizeram a respeito do passado africano, dos problemas e impasses na constituição do campo de conhecimento erudito denominado africanismo. Eis também algumas sugestões gerais a respeito das evidências documentais e dos testemunhos disponíveis, ou possíveis, para a recuperação do passado dos povos que habitaram aquele continente.

Temos ciência que, para nós, brasileiros, o que dificulta o acesso ao conhecimento da história dos povos africanos é o desconhecimento das línguas faladas e escritas naquele continente. Teríamos muito a aprender se dominássemos o árabe, porque diante de nós se abririam os riquíssimos acervos das universidades marroquinas, tunisianas, egípcias, do Senegal, da Nigéria e da República do Mali. Ganharíamos ainda mais se aprendêssemos a língua fula, a língua quimbundo ou a língua swahili, pois teríamos condições de ler a História a partir do ponto de vista dos sujeitos diretamente envolvidos.

Mas enquanto isso não acontece, é imperativo conhecer as principais linhas de rumo do passado africano, sob pena de continuarmos a não querer ver o que nos salta aos olhos, isto é, que os pilares de sustentação de nossa sociedade assentam fundamentalmente na experiência africana, e que conhecer o passado da África é condição imprescindível para descobrir quem somos como povo e como nação. Dessa importância da consciência histórica e do lugar dos sujeitos na enunciação dos discursos históricos, os jovens historiadores africanos estão perfeitamente cientes. Sua posição está bem formulada na máxima segundo a qual "enquanto os leões não tiverem seu historiador, as narrativas da caçada glorificarão apenas o caçador". 


\section{Referências}

CHRÉTIEN, Jean-Pierre. Pourquoi l'Afrique, pourquoi l'histoire?. Afrique \& Histoire (Paris), n 1, 2003, p. 7-19.

CUOCQ, Joseph M. Recueil des sources arabes concernant l'Afrique occidentale du VIII au XVI siècle. Paris: Éditions du CNRS, 1975.

DIOP, Cheikh Anta. L'Afrique Noire Pré-Coloniale. $2^{\mathrm{a}}$ édition. Paris: Présence Africaine, 1987.

EKANZA, Simon-Pierre. Les sources européennes de l'histoire de l'Afrique noire du XV au XIX siècle. Quelle methodologie?. In: Penser et écrire l'bistoire. Disponível on-line no sítio Histoire de l'Afrique de l'Ouest (www.histoire-afrique.org).

FARIAS, Paulo Fernando de Moraes. Afrocentrismo: entre uma contranarrativa histórica universalista e o relativismo cultural. Afro-Ásia, vols. 29/30, 2003, p. 317-343.

. Tombuctu, a África do Sul, e o idioma político da renascença africana. In: Seminário FUNAG-IPRI sobre a África, Palácio do Itamaraty, Rio de Janeiro, 02/03/2007 (www.casadasafricas.org.br).

GONÇALVES, José Henrique Rollo. Quem construiu o Grande Zimbábue: em torno do mito da incapacidade civilizadora dos povos africanos. Diálogos (Universidade Estadual de Maringá), vol. 8 nº 1, 2004, p. 79-106.

HAMPATÉ BÂ, Amadou. A tradição viva. In: Joseph KI-ZERBO (Org). História Geral da África. São Paulo: Editora Ática, 1984. Vol. 1: Metodologia e Pré-História da África.

HÉRAUD, Natalie. L'Afrique du Sud à la recherche de son passé, une enquête historiographique. Clio en Afrique: Bulletin d'Anthropologie et d'Histoire africaine en langue française (Univ. Provence), $\mathrm{n}^{\circ}$ 1, 1997.

HUNWICK, John O. Studies in Ta'rikh al-Fattash, III - Kati origins. Sudanic Studies (Bergen, Noruega), no 11, 2001, p. 111-114.

IDRISSA, Kimba. Historiographie nigérienne, bilan critique et perspectives. In: Penser et écrire l'bistoire. Disponível on-line no sítio da Histoire de l'Afrique de l'Ouest (www.histoire-afrique.org).

KI-ZERBO, Joseph (Org). História Geral da África. São Paulo: Editora Ática, 1984. Vol. 1: Metodologia e Pré-História da África.

KIPRE, Pierre. Sur les enjeux contemporains de l'Histoire de l'Afrique. In: Penser et écrire l'histoire. Disponível on-line no sítio Histoire de l'Afrique de l'Ouest (www.histoire-afrique.org). 
LABURTHE-TOLRA, Philippe. La société des africanistes: des chercheurs et des hommes de terrain (2003). Documento eletrônico disponível no seguinte endereço: www.clio.fr/bibliotheque (acessado em 08/04/2008).

LOPES, Carlos. A pirâmide invertida - historiografia africana feita por africanos. In: Actas do Colóquio Construção e ensino da História de África. Lisboa: Fundação Calouste Gulbenkian, 1994.

M'BOKOLO, Elikia. África negra. História e civilizações. Trad. Alfredo Margarido. Lisboa: Editora Vulgata, 2003, 2 vols.

MAUNY, Raymond. Les siècles obscurs de l'Afrique noire: histoire et archeologie. Paris: Fayard, 1970.

MVENG, Engelbert. Introduction générale. In: VVAA. Perspectives nouvelles sur l'histoire africaine (Congrès international d'Historiens de l'Afrique, University College, Dar es Salam). Paris: Présence Africaine, 1971, p. 15-20.

OGOT, B. A. Trois décennies d'études historiques en Afrique de l'Est: 1949-1977. In: VVAA. Le processus d'éducation et l'historiographie en Afrique (Colloque organisé par UNESCO à Dakar, 1982). Paris: UNESCO, 1986, p. 65-81.

OLIVA, Anderson Ribeiro. A história da África em perspectiva. Revista Múltipla (UPIS, Brasília), Ano IX no 16, 2004, p. 9-40.

PRADINES, Sthépane. Au coeur de l'islam medieval. Gedi, une cite swahili. Archéologia (Dijon), no 396, 2003, p. 29-39.

RODRIGUES, Maria da Conceição. O antigo dinheiro em Africa: contribuição para o estudo da cultura material da Idade do Ferro africana: manilhas e cruzetas. Lisboa: FCG, 2002.

TRIAUD, Jean-Louis. Uma nova Idade Média saeliana a partir das inscrições árabes da República do Mali. Afro-Ásia (UFBA), nº 34, 2006, p. 317-323. 
3

\section{ÁFRICA: UMA HISTÓRIA \\ A SER REESCRITA}

\section{Jorge Euzébio Assumpção}

A História da África é tão antiga quanto à da humanidade, mas somente nos últimos tempos começou a ser difundida no mundo acadêmico brasileiro. A academia, em sua grande maioria comprometida com o eurocentrismo histórico, pouca atenção prestava sobre o continente negro, a não ser a partir do momento em que esse entrou no contexto europeu, com exceção, salvo engano, do Egito, que, de maneira geral, não é tratado como um Estado da África, mas como pertencente à "História do Mediterrâneo", na qual se confundiria com outros povos antigos como os gregos ou os romanos, no que fica desfocado do continente no qual está localizado.

Por muito tempo, alegou-se a falta de estudos sobre a África, devido à ausência de uma literatura escrita em português, o que em parte é verdade, pois a maioria dos escritos africanos provém do árabe e francês. Mas também é verdadeiro que a falta de tradução desses escritos é ocasionada devido ao pouco interesse do tema por parte da intelectualidade brasileira. Essa preferia ficar bebendo das fontes racistas européias produzidas, principalmente, a partir do século XIX, quando a classe intelectual como Gobineau escreveu o Ensaio sobre a desigualdade das raças humanas (1855) - trabalho sobre eugenia e racismo que embasou todo um pensamento de origem racista, o qual se difundiu e ainda perpetua, em parte, até os dias de hoje.

As doutrinas de superioridade entre os povos elaboradas no "Velho Mundo" encontraram um campo fértil junto à intelectualidade brasileira, que conviveu com o trabalho escravo até quase o final do século XIX. O reflexo desse pensamento pode ser espelhado nas 
obras de autores como Nina Rodrigues e Oliveira Viana, entre outros pensadores que influenciaram o pensamento intelectual através de suas obras discriminatórias e preconceituosas, as quais vão se refletir na visão estereotipada sobre o negro brasileiro, assim como sobre o continente africano.

O racismo "científico", elaborado na Europa, tornou-se uma ideologia que foi usada de maneira estratégica para a dominação do continente africano. Dessa forma, a pigmentação da pele passou a ser utilizada como sendo algo determinante nas relações de dominação, nas quais caberia aos arianos, que seriam os verdadeiros brancos, o papel de senhores dos demais continentes.

Nesse contexto de segregação e estereótipos, o continente negro foi saqueado tanto de suas riquezas naturais como também de seres humanos, reduzidos à escravidão. A dominação do solo africano foi respaldada por uma teoria racista que possui atrás de si interesses políticos e ideológicos europeus, os quais conseguiram assim justificar seus atos de violência contra os povos negros. Como afirma Hegel, citado por Leila Hernandes:

O negro representa o homem natural em toda a sua barbárie e violência; para compreendê-lo, devemos esquecer todas as representações européias. Devemos esquecer Deus e a lei moral. Para compreendê-lo exatamente, devemos abstrair de todo o respeito e moralidade, de todo o sentimento. Tudo isso está no homem em seu estado bruto, em cujo caráter nada se encontra que pareça humano [...] (Hernandes, 2005, p. 21).

O que equivale dizer que caberia aos europeus civilizar aqueles que estão em estado de inferioridade. Justificando-se assim todas suas ações, os genocídios e as hecatombes praticados pelos conquistadores não foram considerados como tal, mas, sim, como atos necessários diante de uma missão maior, a de difundir os valores ocidentais aos “bárbaros”. Sobre o assunto, escreveu Antônio Olimpio Sant'Ana:

Em 1835, Arthur de Gobineau produziu um conhecido tratado denominado Ensaios sobre a Desigualdade das Raças Humanas: Raças Branca, Amarela e Negra. O que caracterizava o seu ensaio era a divisão que fazia da raça branca. Esta, segundo Gobineau, tinha três subgrupos: os arianos, que são os verdadeiros brancos criadores da civilização, os albinos, de origem mon- 
gólica, e os mediterrâneos, de origem africana. Sustentava que se o poder permanecesse nas mãos dos albinos e mediterrâneos, a humanidade voltaria à barbárie. Gobineau desejava provar com o seu ensaio que a nobreza européia era ariana, descendente dos nórdicos. Ele via diferenças sobre os demais brancos, que ele julgava pertencerem a setores inferiores. Portanto, racismo de classe, que justifica a posição de privilégio de uns sobre os outros. (Citado em Munanga, 2000, p. 47).

Entretanto, se abandonarmos essa visão preconceituosa e nos debruçarmos sobre a história dos povos africanos, veremos uma outra realidade bem diferente das teorias formuladas por grande parte dos pensadores europeus.

\section{África}

O continente africano freqüentemente é dividido em duas partes: a "África branca" e a "África negra". Alguns autores, para separar o continente, tomam por base o deserto do Saara, segundo maior deserto do mundo (sendo ultrapassado somente pela Antártida), localizado ao norte do continente. Salvo melhor juízo, apresenta uma área total de $9.065 .000 \mathrm{~km}^{2}$, possui um território um pouco menor que a Europa, aproximadamente $10.400 .000 \mathrm{~km}^{2}$. No norte da África, também conhecido como "África branca", estão situados o Egito, a Líbia, o Marrocos, a Argélia, a Tunísia e o Saara Ocidental, sendo esse último ocupado pelo Marrocos.

Essa região, devido às características mencionadas anteriormente, é freqüentemente incluída nas definições do Oriente Médio ou do Mediterrâneo, como salienta Hegel: "A África Setentrional apresenta-se ligada ao mediterrâneo e pode dizer-se que esta parte não pertence propriamente à África senão à Espanha, com a qual forma uma concha”.

Nas palavras de Hegel, pode-se muito bem perceber a tendência de dividir a África em dois grupos: um civilizado, que propriamente não pertenceria ao continente, e o outro "bárbaro", ligado ao continente selvagem. Sobre o assunto, Leila Hernandez, baseada na visão do pensador que escreveu sobre a historicidade africana, diz: "Para 
Hegel, a História seria própria do Velho Mundo, excluindo assim o africano subsaariano, assim como por não admitir aos negros uma autonomia para constituir sua própria história".

Percebe-se assim que a divisão geopolítica entre "África branca" e "África negra" nada mais é do que uma classificação racista e ideológica sobre o continente, em que se tenta classificar o território entre a parte que deu certo e que possui uma História (essa estaria ligada ao Mediterrâneo), e a subsaariana, sendo possuidora das características "bárbaras", sem condições de produzir sua própria história, e que seria a verdadeira "África negra".

As afirmações de Hegel e de outros longe estão da verdade histórica. Mesmo antes do contato direto com os europeus, povos africanos subsaarianos já apresentavam uma organização social, com certo grau de desenvolvimento tecnológico, superando algumas vezes certas regiões européias.

Nos estudos africanos, vemos com freqüência a divisão dos povos negróides (aqueles que não pertencem à “África branca”) em dois grandes grupos: os sudaneses e os bantos.

SUDANESES: povos que habitam a região intertropical africana, entre os desertos do Saara e o Atlântico (Golfo da Guiné), compreendendo o Tchad, o Níger, o Sudão, etc., e as regiões na Costa do Golfo: Nigéria, Daomei ${ }^{1}$ (atual República Popular do Benin), Togo, Gana (antiga Costa do Ouro), Costa do Marfim, estendendo-se até a Libéria, Serra Leoa, Guiné, Senegal. Grupos de escravos vindos dessas regiões, sendo em maior quantidade os Iorubás (Nagô), os Hauçás (Maometanos), da Nigéria, os denominados Jeje, do Daomei, os Fanti-axanti (Minas), da Costa do Ouro. Indivíduos vindos destas regiões.

BANTOS: Grupo lingüístico compreendendo milhões de africanos, com inúmeras línguas e quase trezentos dialetos, que se estende por aproximadamente dois terços da África Negra, desde o Camerum até o sul. Inclui Angola e Congo, de onde nos veio a maioria dos escravos desse grupo e cujas línguas, quimbundo e quicongo, entre outras, são as que mais termos deixaram em nossa linguagem atual (Cacciatore, 1988).

\footnotetext{
${ }^{1} \mathrm{Na}$ Língua Portuguesa, esse termo costuma ser grafado como 'Daomé'.
} 
Embora essa denominação venha sendo questionada por alguns, ainda é a mais usual quando se trata de "ordenar" os africanos. Utilizando-se dessa sistemática classificação, abordaremos as principais formações sociais africanas no sentido oposto ao de Hegel, tentando demonstrar a historicidade existente na África subsaariana, ou, como queiram ainda, África negra.

Salvo engano, são os sudaneses que apresentam os Estados mais bem estruturados, através de Gana, Mali e Songai. Embora esses sejam os mais conhecidos, não podemos incorrer no uso de apenas destacar os três, pois junto com os mesmos tivemos vários outros, talvez não tão bem estudados, mas também influentes no mundo africano.

\section{Gana, o País do Ouro}

Gana, assim como os impérios que o sucederam, localizava-se no Sudão Ocidental. Esse foi o primeiro grande Estado africano ao norte do Equador. Localizava-se aproximadamente entre os atuais estados de Mali e Mauritânia, possui o ouro como sua principal fonte de riqueza. Logo virou objeto da cobiça por parte dos árabes que o trocavam por tecidos, cobre e sal, entre outros. Além das trocas comerciais, Gana era um campo fértil para a expansão do islamismo, religião adotada por vários dirigentes, convertidos pela fé, ou por interesses comerciais.

Esse país africano veio a se tornar fundamental para as pretensões comerciais expansionistas de outros povos, tornando-se o principal fornecedor de ouro do mundo mediterrâneo. Sobre o assunto, diz o cronista muçulmano al-Yakubi: "O rei de Gana é um grande rei. No seu território encontram-se minas de ouro e detém sob sua dominação um grande número de reinos" (Citado em Ki-Zerbo, s.d).

Gana era um título utilizado pelo chefe do reino e significava "senhor da guerra". Como tal, o governante recebia tributação pela extração e pelo comércio do minério. Gana era um Estado tributá- 
rio, ou seja, cobrava tributos sobre as mercadorias que passavam por seu território. Sua capital chamava-se Kumbi Saleh. Para proteger seus domínios, havia um poderoso exército que impunha um controle das rotas comerciais, o que lhes permitia vultosos ganhos.

Segundo Mário Maestri, o modo de produção utilizado por essas comunidades do Sudão Ocidental era o de linhagem ou doméstico, organizado em torno de comunidades familiares ou aldeias. A posse da terra era coletiva, podia ser explorada coletiva ou individualmente. Além da mineração, exercitavam a caça, a pesca e a coleta. Possuíam uma incipiente divisão do trabalho: pastores, ferreiros, mercadores e outras profissões semi-especializadas.

Gana sofreu uma considerável influência islâmica, principalmente por parte de seu grupo governante urbano, pois, ao que parece, existia certa desigualdade social entre os habitantes da Capital e os moradores rurais. Enquanto a capital do reino era descrita como uma grande cidade, com casas reais construídas de pedras, cercadas por muralhas, as moradias destinadas aos componentes não-governantes ou comerciantes eram cabanas de barro com tetos redondos. Destaque também é dado aos negociantes arabizados que viviam à parte, em outra cidade um pouco afastada, com "bazares, plantações irrigadas e nada menos de que 12 mesquitas em plena atividade cultural e religiosa”. O primeiro grande Estado tributário sudanês irá sucumbir no século XIII, diante de uma força maior - o reino de Mali. Ainda sobre Gana, nos diz Mário Maestri:

Hipóteses estapafúrdias foram levantadas pelos primeiros historiadores ocidentais que se interessaram pelo Estado negro. Ventilou-se a possibilidade de que sua fundação fosse obra de judeus sírios fugidos de perseguições romanas na Cirenaica (região da atual Líbia), no séc II dC. As origens do reino são mais simples e menos fantasiosas. (Maestri, 1988, p. 15).

Essa não foi a única vez que historiadores ocidentais tentam desqualificar a história africana, atribuindo seus feitos a europeus ou a nãonegros, em uma nítida demonstração de racismo historiográfico. Outras versões nesse mesmo sentido foram levantadas por pesquisadores 
ocidentais. Basil Davidson estima que Gana teria possuído uma população de aproximadamente um milhão de habitantes, o que, sem sombra de dúvidas, demonstra sua pujança e esplendor (Davison, 1996)

Entretanto, após sucessivos ataques por parte dos almorávidas ${ }^{2}$ do Magreb, os quais eram muçulmanos e procuravam expandir o Islã abaixo do Saara, Gana acabou sucumbindo e sua capital foi tomada e saqueada por volta de 1076. Dez anos depois, o reino conseguiu recuperar sua independência, porém não logrou reabilitar seu prestígio. As caravanas passaram a se desviar das rotas ganenses e optaram por Tombuctu, Gao e Djenne. Era a decadência do primeiro grande império negro sudanês.

A queda do Império de Gana causou um vazio de poder que deveria ser ocupado. Os almorávidas fracassaram nessa missão, pois não falharam na tentativa de controlar as rotas comerciais. Nesse período de transição, ganhou destaque no Sudão a figura de Diarda Kanté, guerreiro de um clã animista e adversário do Islã. Ele tomou as cidades de Kumbi Saleh, Dyara, o Bakumu e o Bumbu. Entretanto, não conseguiu ocupar as jazidas de ouro.

\section{O Império do Mali}

Não se sabe as origens do Mali, sucessor de Gana, um dos mais conhecidos e admirados dentre os Estados antigos africanos. Esse superou em muito a magnificência e o poder de seu antecessor - Gana.

O Império do Mali começou a se estruturar sob a liderança de Sundjata Keita (1230-1255). Senhor absoluto da situação após ter vencido seus inimigos, dividiu em províncias seu império, nomeou governantes e submeteu a uma espécie de servidão os povos que o

\footnotetext{
${ }^{2}$ Nome dado aos integrantes de um movimento político-religioso muçulmano, cujos primeiros adeptos viviam no Saara Meridional, liderado por Iusef Ibn Tashufin, que tomou o poder no Magreb, constituindo um vasto império territorial. Em 1086, cruzando o Estreito de Gibraltar, os almorávidas adentraram nos territórios al-Andaluz, ao sul da atual Europa.
} 
haviam combatido. Com ele, os Keita fundaram o Império do Mali. O governo de Sundjata foi de tal forma marcante que até os dias de hoje ele é reverenciado através de oferendas, como rezam antigos costumes da tradição africana.

O sucessor de Sundjata foi seu filho, Mansa Uli. Conforme nos explica o africanista brasileiro Alberto da Costa e Silva, mansa era um título usado pelos governantes locais: "Cada um desses chefes continuou a exercer o governo local, mas todos cederam o título de mansa - ou Mandimansa - a quem na guerra os comandara" (Costa e Silva, 1992, p. 291). Depois de Mansa Uli, essa designação passou a ser usada por todos os demais, que chefiaram o Império.

Salvo melhor juízo, Uli, assim como seu pai, fora convertido ao islamismo, não se sabe se por fé ou por senso de oportunidade. Isso vale também para outros governantes do império. Todavia, o mesmo não se deu com as populações dos territórios sob sua jurisdição, as quais continuaram a praticar suas crenças animistas. A conversão ao islamismo por parte do governante não significa deixar as crenças nativas de lado. Em muitos casos, parece ter sido a conversão ao Islã uma estratégia política utilizada pelo governante para, talvez, poder usufruir de certas vantagens. Em muitos casos, esses abraçavam a fé em Alá, mas continuavam a praticar suas crenças locais, sem o mínimo embaraço. Sobre isso, a opinião de Alberto da Costa e Silva é a seguinte:

A viagem à Meca de Mansa Uli pode ter-lhe sido ditada por exigência de uma profunda fé. Ou ter sido mero expediente político, para estabelecer melhor diálogo com os Estados muçulmanos do outro lado do Saara e para ampliar seu prestígio entre os islamitas do Mali. E não só entre estes, pois tanto os maometanos quanto os pagãos acreditavam que a estada em Meca fortalecia o baraca, o poder propiciatório do rei, sua capacidade de influir favoravelmente sobre a terra e sobre o clima, sobre as colheitas e sobre o gado, sobre a fertilidade das mulheres e o bem-estar do povo. (Costa e Silva, 1992, p. 293).

Foi durante o Império do Mali que Djenne e Tombuctu começaram a emergir como prósperas cidades comerciais. Sobre Tombuctu, diz Maestri: 
Centro cultural Tombuctu, que procurou a proteção dos senhores de Mali, transformou-se em um dos principais centros comerciais do Sudão Ocidental. Nos fins do séc. XVI, possuía em torno de 25 mil habitantes, 26 alfaiatarias, com até 200 aprendizes cada uma, e nada menos do que 150 escolas alcoranistas. Basil Davidson, em Revelando a Velha Africa, registrou a referência de Leon, o Africano, a Tombuctu: 'Em Tombuctu, há muitos juízes, médicos e letrados, e todos recebem bons estipêndios do rei, que tem grande respeito pelos homens de saber. Livros manuscritos têm ali grande procura e são importados da Barbaria. O comércio livreiro é aí mais lucrativo que qualquer outra espécie de negócio’. (Maestri, 1988, p. 29).

Tombuctu foi centro de um comércio internacional, onde tudo era negociado - sal, escravos, marfim, etc. Havia também um grande comércio de livros de História, Medicina, Astronomia e Matemática, bem como uma grande concentração de estudantes. A importância cultural de Tombuctu pode ser percebida através de um velho provérbio africano: "O sal vem do norte, o ouro vem do sul, mas as palavras de Deus e os tesouros da sabedoria vêm de Tombuctu”. A prosperidade, a pujança e a riqueza do Mali ficam ainda mais evidenciadas durante o reinado de Mansa Kanku Mussa (1307-1332). O erudito egípcio al-Umari registra que, quando de sua ida à Meca, local de peregrinação muçulmana, teria levado consigo cerca de 8 mil cortesãos, guerreiros e servos, como também de 10 a 12 toneladas de ouro. Já em Meca, comprou casas e terrenos, distribuiu esmolas e presentes. De volta ao Mali, trouxe consigo letrados comerciantes e religiosos. Kanku Mussa falava e escrevia em árabe.

A viagem do Mansa Musa foi cantada em prosa e versos por décadas seguintes, tal foi a sua suntuosidade. Porém, essa demonstração de poder e riqueza não deixara de trazer consigo conseqüências negativas, pois, a partir da mesma, os povos africanos começaram com maior intensidade a ser alvos da cobiça européia. Por volta do século XV, principiara a decadência do Mali, quando, dentre outros motivos, foi atacada pelos tuaregues (povo nômade do deserto do Saara). O Estado do Mali passou a ser dividido, desde então, em vários pequenos reinos. 


\section{O Império Songai}

Foi o último, mas o mais poderoso dos Estados tributários sudaneses, alcançando grande opulência e poder. O seu território expandiu-se desde Mali até a atual Nigéria. Teve grande importância também como propagadora da cultura islâmica.

As populações songais são divididas em dois grandes grupos: os sorkos, que praticavam a pesca, e os gows, caçadores. A principal cidade de Songai era Gao, local de encontro das principais rotas saarianas. A cidade era habitada por negociantes. O Rio Níger, principal via fluvial da região, servia como meio de transporte e comércio, principalmente de sal.

A origem do Império Songai está envolta em lenda. A História registra que Gao foi conquistada pelo Império do Mali, libertandose em 1337 por dois príncipes songais. Gao havia se tornado capital por Dia Kossoy, décimo-quinto rei de sua dinastia, o mesmo foi o primeiro rei ao converter-se ao islamismo em 1009. No século XIV, Gao se igualava em importância com a capital do Mali.

Os governantes songais recebiam a denominação de soni. Em 1464, tendo sua influência cada vez maior na região, um deles, conhecido como Sonni Ali, o Grande (1464-1493), impôs a derrota ao Império do Mali. Ali, não se mostrou somente um grande general, mas também um notável administrador. Após ter assegurado sua vitória militar, dedicou-se também à administração de seus novos domínios. Para tanto, mandou construir canais de irrigação e embarcações para controlar e aprimorar o comércio. Vale registrar que Ali era adversário dos muçulmanos.

Após a morte de Sonni Ali, seu herdeiro perdeu o poder para Mohammed, de origem soninquê, que se aliou ao partido muçulmano. Durante o reinado de Mohammed, Songai conheceu todo o seu poder. O império foi dividido em quatro vice-reinados. Mohammed tomou medidas unificadoras quanto aos pesos e medidas, regulamentou a arrecadação de impostos e formou um exército regular composto por "escravos e prisioneiros". 
O poder de Songai se deu através da força, submetendo o antigo reino do Mali, alguns Estados hauçás, entre outros. Mediante a animosidade e a nova conjuntura, o Império Songai começa a se desintegrar nas mãos do sucessor de Mohammed.

Vale a pena destacar a educação em Songai, pois já no século XII existiam cerca de 25.000 estudantes em Tombuctu para uma população de aproximadamente 100.000 pessoas. O progresso e a prosperidade desta região deram-se até o século XVI, quando, por vários motivos, começou a entrar em decadência.

A população e a magnificência de Gao demonstraram que os Estados africanos não precisaram dos reinos europeus para alcançar uma formação social organizada, em alguns aspectos em posição superior a alguns povos europeus.

Entretanto, não podemos ficar na ilusão de que no continente negro existiram somente os três grandes Estados apresentados. Além desses, podemos destacar as cidades-Estados Hauçás, os reinos do Golfo da Guiné - Benin, Oió, Abomei -, a Confederação Achânti, as comunidades iorubás, entre outros.

\section{Os Povos Bantos}

Por fim, resta ainda abordarmos algo a respeito dos povos comumente chamados de bantos, dentre os quais podemos destacar os reinos do Congo, Mdongo, assim como o Monomotapa, dentre outros. Essas nações conheciam uma agricultura com base na metalurgia do ferro. Sobre a ciência e a arte de construir estruturas metálicas, diz Maestri:

A metalurgia do ferro permitiu que os povos bantus assentassem suas civilizações sobre uma economia fundamentalmente agrícola, onde os instrumentos simples de ferro e a produção de cereais desempenhavam um papel essencial. Esta metalurgia ligeira, que supria as necessidades fundamentais da população, manteve-se sem maiores modificações até os tempos coloniais. As técnicas metalúrgicas africanas, importadas junto com os passageiros dos tumbeiros transatlânticos, foram, por muitos anos, a base da metalurgia do Brasil escravista (Maestri, 1988, p. 100). 
Também foi entre os bantos que na era escravista teremos uma das figuras africanas de maior destaque - a rainha Nzinga Mbundi, do reino do Ndongo.

Um dos mais destacados e importantes "impérios" bantos talvez tenha sido o Congo. Foi fundado provavelmente por Ntinu-Wene, chefe Kicongo. Sua capital localizava-se em Mbanza Congo, atual São Salvador, em Angola. O governante do Congo possuía o título de manicongo, que significa "Senhor do Congo". A ele cabia nomear os governadores das províncias, e esses juntavam aos seus nomes o título de manicongo.

Os reinos do Congo e de Ndongo apresentavam uma economia de subsistência, baseada na agricultura, com o desenvolvimento de práticas agrícolas complexas. Essas atividades estavam alicerçadas na mão-de-obra feminina. Produziam objetos de ferro e cobre de alta qualidade, como também de marfim. Criavam galinhas, cachorros e cabritos. A moeda de circulação no território era o nzimbo, uma espécie de caramujo. O comércio do sal era monopólio do manicongo. Em 1482, Diego Cão aportou no Rio Zaire, dando início à conquista da região.

No começo do século XVI, havia duas facções no império: uma favorável aos portugueses, liderada por Afonso I (1509-1540), que adotou o cristianismo, e outra contrária, encabeçada por seu irmão, Mpanzu a Katima, que era abertamente antilusitano e pagão. O primeiro se saiu vitorioso da disputa e iniciou a evangelização da terra, em aliança com os lusos.

Essa união levou o reino a participar do comércio negreiro. E, aos poucos, o manicongo começou a perder o poder para os traficantes a serviço dos reis portugueses. Todavia, a submissão não pode ser atribuída a todos os manicongos, pois alguns resistiram a este domínio, como foi o caso de Antônio I, que enfrentou, em 1665, tropas européias. Entretanto, o mesmo foi derrotado, aprisionado e decapitado. Essa derrota levou a uma divisão do Congo em três reinos, e o mergulhou na desordem. 
O reino Ndongo, salvo engano, foi fundado no início do século XVI, por um chefe quimbundo. A autoridade máxima do reino denominava-se de ngola. Esses permaneceram sob o domínio dos manicongos até 1556 , quando, com o apoio de alguns portugueses, derrotaram-nos. De sua capital, Cabassa, o ngola vencedor, Inene, mandou uma embaixada a Portugal a fim de estabelecer uma política de aliança diretamente com a Coroa, sem intermediários.

Mas a relação entre os lusos e os ndongos não foi pacífica. Ela também enfrentou a resistência de alguns ngolas, os quais se sentiam ameaçados diante da presença e dos interesses dos lusos em sua região. Com o apoio do manicongo, os europeus entraram em conflito armado com o senhor do Ndongo em uma sangrenta guerra.

As tratativas de paz com os portugueses foram realizadas já no século XVII, sob a liderança de Nzinga Mbundi, a rainha Ginga. Como esta detinha grande prestígio entre os seus, tornou-se soberana após romper as regras de sucessão ao trono Ndongo. Usando de diplomacia e artimanhas, não hesitou ao converter-se ao catolicismo para alcançar seus objetivos, obtendo grandes vantagens na mesa de negociação com os portugueses. Nzinga foi uma figura marcante no Ndongo, e hoje serve de referência a vários grupos de ativistas negros no Brasil.

No entanto, assim como aconteceu com os povos sudaneses de Gana, Mali e Songai, também entre os bantos houve outros povos além do Congo e Ndongo que exerceram singular importância no mundo africano, dentre os quais os xonas, os zulus e o Império do Monomotapa. Também esses tiveram suas estruturas abaladas com a chegada dos europeus e, conseqüentemente, sofreram os malefícios ocasionados pelo tráfico transatlântico, o qual modificou as estruturas e o desenvolvimento dos povos africanos.

Salvo melhor juízo, os povos bantos foram aqueles que mais tiveram contato com o tráfico negreiro. Entretanto, tanto bantos quanto sudaneses foram vítimas do maior holocausto da história mundial. Segundo Walter Rodney (1975), a cifra de pessoas vítimas do tráfico di- 
reto ou indireto beira os 100 milhões de indivíduos. Isso acarretou uma estagnação populacional no continente em relação ao crescimento populacional da Europa e da Ásia, conforme se pode ver no quadro abaixo:

\section{Evolução da População Continental, em Milhões de Habitantes}

\begin{tabular}{|c|c|c|c|c|}
\hline CONTINENTE & 1650 & 1750 & 1850 & 1900 \\
\hline África & 100 & 100 & 100 & 120 \\
\hline Europa & 103 & 144 & 274 & 423 \\
\hline Ásia & 257 & 437 & 656 & 857 \\
\hline
\end{tabular}

O tráfico internacional de escravos mudou, sem dúvida alguma, a história do continente negro, o que torna impossível analisar a atual situação dos africanos e seus descendentes sem levar em conta a diáspora dos povos negros.

\section{Referências}

CACCIATORE, Olga Gudolle. Dicionário de cultos afro-brasileiros. $3^{\mathrm{a}}$ ed. Rio de Janeiro: Editora Forense Universitária, 1988.

COSTA E SILVA, Alberto da. A enxada e a lança: a África antes dos portugueses. Rio de Janeiro: Nova Fronteira; São Paulo: Edusp, 1992.

DAVISON, Basil. À descoberta do passado de África. Lisboa: Sá da Costa Editora, 1996.

HERNANDEZ, Leila Leite. A África na sala de aula. São Paulo: Selo Negro Edições, 2005. 
KI-ZERBO, Joseph. História da Africa Negra. Mem Martins: Publicações Europa-América, s.d.

MAESTRI, Mário. História da Africa negra pré-colonial. Porto Alegre: Mercado Aberto, 1988.

MUNANGA, Kabengele (Org). Superando o racismo na escola. Brasília: MEC/ Secretaria de Educação Fundamental, 2000.

RODNEY, Walter. Como a Europa subdesenvolven a África. Lisboa: Seara Nova, 1975. 


\section{4 \\ O COMÉRCIO TRANSAARIANO \\ E OS ESTADOS DO SUDÃO OCIDENTAL: \\ SÉCULOS VIII-XVI}

\section{Diego Souza Marques}

Durante o período que correspondeu à Idade Média européia pelo calendário cristão, os povos africanos não estavam vivendo em período pré-histórico, como muitos acreditam. Havia uma multiplicidade de formações estatais e sociais no continente, e alguns Estados africanos mantinham relações freqüentes com as sociedades que consideramos "avançadas" para o período, como as sociedades islâmicas do Oriente Médio, a Índia e a própria China da dinastia Ming. Para o pesquisador Basil Davidson, havia nesse período centros de comércio e de trocas maiores que os da Europa.

No presente texto, apresentaremos as relações das rotas e dos centros comerciais com as formações estatais do Sudão africano, através da formação, da sustentação e do declínio do Reino de Gana e dos Impérios do Mali e do Songai. Observaremos como se deu a relação das práticas comerciais com as estruturas de poder estatal, embora não se possa considerar que o comércio tenha sido um fator que determinou tanto a formação quanto o declínio daquelas formações estatais.

\section{Caravanas e Centros Comerciais em Gana}

Na região onde o deserto do Saara começa a se encontrar com o ambiente de savanas, o Sahel, existia uma relação entre os pastores nômades e os agricultores sedentários. A convivência entre esses grupos gerava, de uma forma mais generalizada, um intercâm- 
bio complementar que pode ser entendido como uma espécie de comércio. Esterco para a fertilização e pasto para os animais são um exemplo.

Dentro dessa relação, também existe o fato da região do Sahel ser um caminho de direção dupla para as trocas entre o que vem do deserto e das savanas. Por ali passavam as caravanas das já tradicionais rotas do deserto, as quais também tinham suas próprias aldeias como intermediárias de trocas, criando assim uma rede que se configurava das mais variadas formas. Compra, venda, tributos de passagem, hospedagem, serviços de guia ou de proteção eram atividades freqüentes, que ligavam diferentes pontos do centro-norte do continente africano e que tinham o Sahel como ponto central desse movimento.

Iam para o Sudão africano, por exemplo, o sal, o cobre, bijuterias de vidro, pedras raras, perfumes, panos de algodão, tâmaras e espadas. Voltavam produtos como a goma, o âmbar cinzento, a pimenta malagueta, o marfim, peles, homens escravizados. Viagens essas que chegavam ao Sahel de camelo e, após, eram transferidas para lombos de jumentos, sendo às vezes transportadas pelos próprios homens. Entre tantas mercadorias, existiam as mais importantes e cobiçadas, talvez até pela sua própria importância tanto dentro da África como no exterior. Seriam elas o sal, o ouro e os homens escravizados.

Esses produtos que se deslocam nessa rede de forma mais importante que outros se relacionam diretamente com a formação de centros de poder e formas estatais. $\mathrm{O}$ acesso às salinas, assim como às minas de ouro, e o controle dos cruzamentos e eixos de difusão das rotas foram importantes para as relações de dependência e ligações que deram corpo aos reinos e impérios sudaneses. Um exemplo disso é o próprio tráfico de cativos na região subsaariana: uma aristocracia guerreira poderia se formar através da dominação e escravização de grupos e sua posterior troca com mercadores por artigos que fortaleciam práticas guerreiras (como os cavalos, por exemplo).

Dentro dessas características é que pode ter se dado o desenvolvimento do reino de Gana a partir do século VIII da era cristã. 
Sua posição geográfica se localizava exatamente nessa área entre o Saara e as cabeceiras dos rios Níger e Senegal. Era uma posição fundamental para o controle das principais rotas de comércio entre o deserto e a savana. A "terra do ouro", controlando o fluxo de ouro que vinha mais do sul e as fontes de sal, criou condições para a emergência de um poder militar e para sustentar um tipo de governo e províncias através da possibilidade de manutenção de instrumentos que serviam à prática guerreira e um corpo de funcionários administrativos.

Há possibilidades que a primeira dinastia do reino de Gana provenha de cameleiros do deserto que se instalaram nos portos do Sahel para adquirir, principalmente, o ouro. Dessa maneira, se criou também uma forma de penetração do Islã, e o reino começa a figurar entre os textos dos viajantes árabes.

Fica complicado relacionar as formas de poder de Gana com as questões comerciais pelo fato de o reino não ser uma unidade política no sentido tradicional do termo. Não era um império unificado e que buscava expansão territorial, mas se estendia através da influência sobre diversos súditos, juntamente com suas próprias características de organização, sendo assim uma soberania exercida sobre homens e não sobre a terra. No aspecto do comércio, era interessante para o reino manter e ampliar o controle sobre os sujeitos que atuavam nessas redes de circulação.

Esse caso se mostra, principalmente, na tensão com os berberes do deserto, os quais controlavam as rotas dos califas, o oásis, os poços do deserto e as minas. A cidade de Audagost, que se localizava nessa área de tensão, oscilava entre o conflito e a cooperação com Gana; seus comerciantes controlavam o comércio do sal e a saída das rotas para o deserto, enquanto Gana controlava o ouro e as trilhas para a savana e o cerrado. Com relações complementares, a cidade e o reino (que depois a incorporou, o que correspondeu ao apogeu do mesmo) não se desligaram totalmente, apesar do conflito. Cidades muito importantes, que geralmente 
eram as que estavam no cruzamento de rotas ou eram as fontes de alguma riqueza, tinham certa autonomia e privilégios no reino. Outro exemplo pode ser a própria capital, Kumbi Saleh, que era dividida em duas, uma para a administração do reino e outra ligada aos comerciantes, principalmente muçulmanos.

Assim, o governante dependia do comércio para sustentar as estruturas do poder, e o declínio do reino de Gana coincidiu com a perda dessas rotas, principalmente pelo movimento de islamização "radical" dos almorávidas e posteriormente dos almoâdas ${ }^{1}$ que, pouco a pouco, enfraqueceram o reino no século XII, monopolizando o comércio de ouro e a cunhagem de moedas. Não foi uma conquista do reino, mas o enfraqueceu a tal ponto que os mossis o tomaram militarmente, o que fez com que muitos mercadores soninquês (etnia dominante em Gana) emigrassem para outras áreas.

\section{Rotas e Produtos do Império do Mali}

Juntamente com a expansão islâmica África subsaariana adentro e o declínio do reino de Gana, podemos relacionar a ascensão do Império do Mali no século XIII. Em primeiro lugar, as conquistas dos povos sossos deslocam mais para o sul - do Sahel para a savana - o centro do comércio transaariano. As mudanças nas fontes de ouro durante o século XIII, indo mais para o sul, devido também às conquistas almorávidas e almoâdas, fizeram com que houvesse disputas para controlar essas rotas. Os mansas (futuro título dos imperadores do Mali) tiveram sua origem em grupos de

\footnotetext{
${ }^{1}$ Adeptos de movimento religioso muçulmano de caráter fundamentalista, fundado em torno de 1120 nas montanhas do Atlas por Ibn Tumart e chefiado militarmente por Abd al-Mumin como reação contra o estéril legalismo dos almorávidas, cujo puritanismo original teria sido corrompido. Os almoâdas pregavam um regresso à estrita moralidade e ao texto do Alcorão. Tomaram o poder no Magreb em 1148, estendendo suas conquistas militares aos domínios almorávidas em al-Andaluz.
} 
caçadores ligados às minas de Buré, os quais impunham tributos aos que procuravam explorá-las. Assim, a proteção dessas rotas fez com que surgissem formas políticas organizadas de diferentes grupos nas savanas.

A partir dessas associações é que podemos entender o surgimento do Império do Mali. Sua extensão dominava as fontes do ouro, os portos caravaneiros e os caminhos que ligavam uns aos outros. Tomaram as cidades de Gao, Walata, Tombuctu e Djenne, as jazidas de sal de Tagaza e as minas de cobre de Tadmekka, tendo sempre o Rio Níger como seu eixo central, principalmente na circulação das riquezas.

Os caminhos que tinham essas localidades como principais eixos eram fortemente ligados. Ibn Battuta, viajante marroquino que visitou o Sudão em meados do século XIV, período de apogeu do Império do Mali, definiu essas rotas como caminhos seguros e que o comerciante não precisava levar grandes quantidades de provisões nas viagens, pois as aldeias tinham a estrutura necessária para alojamento e alimentação. A cidade de Djenne, por exemplo, era um importante centro produtor agropecuário e ligava a região de savana com a floresta, principalmente por causa do comércio de noz-de-cola. Essa floresta ganhou uma grande importância durante o Império do Mali, pois comerciantes entravam nela para trocar sal por ouro, criando novas relações com as regiões mais ao sul, juntamente com a expansão do próprio Islã.

O Islã já estava presente entre os governantes africanos desde o século XI, antes mesmo da expansão que enfraqueceu o reino de Gana. Mercadores islâmicos já podiam se fazer presentes na corte do imperador Sundjata Keita (1235-1255), e muitos comerciantes acabaram aceitando o Islã (além dos próprios muçulmanos que já praticavam o comércio na região), o que melhorou as relações políticas com berberes do norte e as próprias relações comerciais, ao mesmo tempo em que criavam algum critério de unidade em um império muito heterogêneo. 
A influência do Islã alcançou o ponto máximo depois da peregrinação do Mansa Mussa à Meca, em 1325. Ele levou tanto ouro em sua passagem pelo Egito que chegou a desvalorizar o metal na região. Do mesmo modo, trouxe na viagem de volta credores e muitos artistas, o que propiciou posteriormente o surgimento de uma elite de letrados, principalmente em Tombuctu e Djenne, o que fez com que a Europa passasse a se interessar por aquele império, levando a que, algum tempo depois, o eixo comercial se deslocasse do deserto do Saara para a costa atlântica durante a segunda metade do século XV.

Esse comércio era então essencial, pois era dele que provinham as tributações que sustentavam o poder. O ouro do mansa provavelmente vinha de armazéns onde se acumulava o metal nas regiões auríferas, ligados aos impostos do comércio de longo curso. Assim se podia presentear a aristocracia e os chefes aliados, trazer as novidades que estavam restritas a uma elite dos grandes centros urbanos, como artigos de luxo, letrados e doutores da fé. Os cavalos, tão importantes para a aristocracia guerreira, tinham seu comércio monopolizado pelo mansa e eram trocados por escravos.

De modo semelhante ao que ocorria em Gana, a organização política do Império do Mali se baseava na imposição de autoridade sobre um aglomerado de reinos ou chefaturas. Desse modo, o império era heterogêneo e comportava poderes locais que mantinham linhagens próprias no controle das áreas, ao mesmo tempo em que estavam subordinadas ao poder central do mansa. Somente nas localidades de grande importância estratégica ou comercial é que o governo mantinha um controle direto, através de algum membro da família real ou de algum escravo da corte. Assim, esse império se mantinha de forma flexível e com fácil incorporação de novos chefes locais, que poderiam manter seu poder ao mesmo tempo em que estavam ligados a uma poderosa organização militar e política.

Essa estrutura poderia também ser proveitosa para os próprios comerciantes, pois facilitava - apesar da tributação e de alguns mo- 
nopólios do mansa - seu deslocamento através de um território seguro e as possibilidades de negócios com uma rede bem extensa. No período de apogeu do Mali, certos grupos de comerciantes chegaram a estabelecer uma rede comercial especializada, tendo relações com povos das florestas e do litoral. Eram verdadeiras companhias que chegavam a ter escolta própria e um serviço de correios.

A heterogeneidade desse império foi o que preparou seu declínio a partir do século XV. Conflitos internos dentro dessas redes foram enfraquecendo o controle sobre os poderes locais, ao mesmo tempo em que novos inimigos do império estavam se formando na região do Sudão. Aliado a esses fatores, existe outro, não menos importante: o gradual deslocamento do centro de riquezas do Mali para a costa atlântica.

No âmbito externo, o Mali começou a sofrer ataques dos berberes, de tuaregue e do Império Songai. Cidades como Tombuctu, Walata, Nema, Djenne e Gao foram tomadas, enfraquecendo a influência do império no Sudão e no Sahel. Ao mesmo tempo, no norte do Sudão, desenvolvia-se outra potência na região dos povos fulas, o que fez com que os caminhos que ligavam o Ocidente com o Oriente africano deixassem de ser controlados pelo Mali. Dessa maneira, as caravanas tinham que desviar em suas rotas tradicionais, deslocando o comércio de ouro para a região do Gâmbia, perto do litoral atlântico.

As províncias da região do Rio Gâmbia não tinham muita importância para o império até a metade do século XV. Começou, então, a se desenvolver ali uma relação comercial com os portugueses, transformando essa região em um importante centro de trocas para os europeus, em contraste com as relações com os muçulmanos na região transaariana.

Os portugueses procuraram, então, ganhar a confiança de chefes locais, enviando, inclusive, missões diplomáticas para tratar de negócios com os soberanos. Importantes cidades se formaram ao longo do Rio Gâmbia, e os poderes locais começaram a se emancipar do domínio do mansa. Já no século XVI, com o declínio do comércio do ouro no Sudão, os manden passaram a se deslocar para o sul, região de florestas, para as rotas das nozes-de-cola. 


\section{O Comércio no Império Songai}

De forma relativamente paralela ao desenvolvimento do Império do Mali, pode-se contar a emergência dos songais, que conseguiram sua independência frente aos manden já no século XIII. No século XIV, assumiram o controle sobre a região de Gao, importante cidade que se tornou a capital do futuro império. Organizaram-se na região da Curva do Níger, constituindo sua força militar nas canoas que subiam e desciam o Níger, ao mesmo tempo em que suas incursões militares tinham por característica inicial a pilhagem. No século $\mathrm{XV}$, tomaram a iniciativa contra o Mali os tuaregues, os mossis e os fulas, principalmente na disputa pela tomada de Tombuctu, na época em que o poder do Mansa estava mais deslocado para o litoral.

A expansão militar songai aconteceu durante o reinado de Sonni Ali (1464-1493), que abandonou as práticas de pilhagem e deu início a uma conquista territorial. O império passou a dominar, então, importantes centros de comércio ao mesmo tempo em que sua estrutura política começou a ser centralizada, baseando-se em princípios islâmicos e consuetudinários. Tinha um forte corpo de funcionários reais, como os comissários que eram enviados periodicamente às províncias, para, entre outras funções, arrecadar impostos extraordinários dos comerciantes das grandes cidades.

As cidades mantinham uma certa autonomia frente à intervenção direta dos $a s k i y a s^{2}$ Muitos funcionários administrativos realizavam as mais diversas funções nesses grandes centros de comércio, o que fazia também com que as questões de "regularização" das práticas de negócios fossem mais bem claras. Policiamento dos mercados, inspeção de pesos e medidas, coleta de impostos e inspeção das alfândegas eram atividades desempenhadas em nome dos governantes songais. Além dos impostos colhidos através de uma "burocracia", outras fontes de renda para a manutenção do poder vinham dos

\footnotetext{
2 Título dos governantes songais.
} 
rendimentos das propriedades do soberano, dos impostos sobre colheitas, das taxas e dos direitos alfandegários sobre o comércio.

Quatro grandes e antigas cidades passaram a fazer parte do Songai: Tombuctu, Walata, Djenne e Gao. Esses centros tinham grandes contatos com os mercados do Saara e com a Europa mediterrânea. Os comerciantes eram bem organizados ao longo das rotas, tinham sucursais em algumas aldeias, frotas comerciais no Rio Níger, camelos, bois e jumentos para o transporte de mercadorias e as habituais referências de valor que funcionavam como moeda (principalmente o ouro, o sal e o cobre). Os laços de parentesco exerciam grande importância nas práticas comerciais, e até mesmo alguns camponeses, artesãos e religiosos participavam dos intercâmbios.

Com um comércio bem organizado e um sistema de governo mais coeso do que os Estados que o antecederam, o Império Songai alcançou uma extensão territorial que integrava o litoral atlântico, o sul do Saara, o Sahel, as savanas, e se estendia na direção leste. As redes comerciais se desdobravam tanto dentro do Sudão seguindo, principalmente, o Rio Níger, quanto para fora do continente.

Tamanha extensão de influência levou a um conflito com o Marrocos, com quem o Songai disputava o controle das fontes de sal do Saara central. No século XVI, os sultões marroquinos reivindicaram o direito de propriedade sobre elas, aproximadamente no mesmo período em que o Marrocos assumiu o controle das fontes de ouro. Na guerra que se sucedeu, os exércitos marroquinos, munidos de armas de fogo, levaram a melhor, invadindo e destruindo o Estado Songai em 1591.

\section{Considerações Finais}

Vimos no presente artigo que as rotas de comércio, suas fontes de riqueza e a circulação de mercadorias através delas se relacionaram estreitamente com as formas de poder no Sudão africano. Nos mapas, os limites desses Estados se sobrepõem às rotas e às cidades comerciais, e 
tanto sua ascensão quanto seu declínio estão relacionados a elas. Podemos notar também que o próprio comércio às vezes não seguia uma lógica territorial de reinos - o caso das relações entre a cidade de Audagost com o reino de Gana é um bom exemplo disso. Isso ocorria porque naquele momento não havia limites territoriais bem definidos, mas prevalecia uma forma própria de organização daqueles Estados. Tratava-se de aglomerados de reinos e poderes locais que formavam redes.

Outro ponto importante é que, em muitos casos, o comércio era voltado mais para um sistema de trocas do que para algum tipo de excedente que desenvolvesse uma estrutura "econômica". Os produtos trocados eram tributados, produzindo em grande parte a riqueza que constituía a base de sustentação do poder dos soberanos.

Além dessas formas internas que faziam com que o Reino de Gana e os Impérios do Mali e Songai ganhassem corpo e continuassem a se manter, a relação com o exterior também foi muito importante. As atividades comerciais ligavam-nos ao Mar Vermelho e ao norte da África; ao Mediterrâneo já no século XV e ao Atlântico no século XV. O Sudão africano ligava-se desse modo a uma economia "mundial" que estava em desenvolvimento no início da era moderna européia.

\section{Referências}

IBN BATTUTA. A través del Islam. Madrid: Editora Aliança, 1987.

CISSOKO, Sékéné Mody. Os songhai do século XII ao XVI. In: Djibril Tamsir NIANE (Coord.). História geral da Africa. São Paulo: Editora Ática/ UNESCO, 1978. Volume IV, A África do século XII ao século XVI.

COSTA E SILVA, Alberto da. A enxada e a lança. $3^{\text {a }}$ edição. Rio de Janeiro: Editora Nova Fronteira, 1996.

DAVIDSON, Basil. À descoberta do passado de África. Lisboa: Livraria Sá de Costa, s.d.

HUSSAIN, Monés. Las rutas de comercio en el sahara africano segun los escritores árabes. In: Actas IV congresso de estudos árabes e islâmicos. CoimbraLisboa, 1968. 
LY-TALL, Madina. O declínio do Império do Mali. In: Djibril Tamsir NIANE (Coord.). História geral da África. São Paulo: Editora Ática/UNESCO, 1978. Volume IV, A África do século XII ao século XVI.

M’BOKOLO, Elikia. Africa negra - bistória e civilizações. Lisboa, Editora Vulgata, 2003.

NIANE, Djibril Tamsir. O Mali e a segunda expansão manden. In:

(Coord.). História geral da África. São Paulo: Editora Ática/UNESCO, 1978. Volume IV, A África do século XII ao século XVI. 
5

RELIGIÃO, PODER E SINCRETISMO:

O ISLÃ NO IMPÉRIO SONGAI

(SÉCULOS XV-XVI)

\section{Bárbara Macagnan Lopes \\ Leonardo Veiga Guarnieri}

As origens do processo de islamização do Sudão Ocidental, ocorrido ao longo do período anterior à expansão européia, em termos gerais, deveram-se inicialmente mais a fatores de ordem pragmática, principalmente econômica, do que de ordem espiritual ou teológica.

É fato que, apesar das difíceis condições climáticas, as quais impossibilitavam um intenso povoamento da região, o deserto do Saara era, na época anterior aos descobrimentos, zona de intenso tráfego de caravanas mercantes, que o cruzavam repetidamente, transportando o ouro sudanês até as grandes praças comerciais marroquinas e retornando com produtos provenientes das regiões do Magreb, da Europa e do Levante, ${ }^{1}$ como tecidos finos, perfumes, cavalos (muito apreciados no Sudão devido à sua importante função militar), o cobre e o vidro.

O comércio transaariano foi o principal elemento da economia dos impérios e reinos sudaneses e o maior responsável pela riqueza dos seus governantes. Tal atividade passava obrigatoriamente pelo norte da África devido à localização das grandes praças comerciais. Essa região, habitada pelas populações berberes, havia sido islamizada e arabizada de maneira muito mais efetiva no século XIII, e estabelecido laços muito mais estreitos com o

\footnotetext{
${ }^{1}$ Região do Oriente Médio, ao sul dos Taurus, limitada a oeste pelo Mediterrâneo e a leste pelo Deserto da Arábia e pelo atual Iraque.
} 
mundo árabe do que aqueles que possuíam com as regiões ao sul do deserto.

Considerando ambos os fatos, a dinâmica das rotas comerciais transaarianas e a islamização mais efetiva do norte da África, podemos ver como o comércio exerceu um papel duplo na expansão do islamismo para a África subsaariana Ocidental: primeiramente, os mercadores berberes, ou os sudaneses que entraram em contato com a civilização berbere, trouxeram do norte os ensinamentos da religião muçulmana e mesmo os costumes de uma "cultura islâmica" já estabelecida, e, por outro lado, as relações comerciais entre as duas regiões tornaram a conversão ao islamismo uma estratégia diplomática eficiente, visto que a mesma incluiria o Sudão no mundo muçulmano e, assim, facilitaria as relações comerciais entre sudaneses e berberes, devido à unificação das identidades religiosas e culturais de ambos os povos que essa islamização proporcionaria.

Ainda que não afirmemos que foram apenas esses interesses comerciais os promotores da conversão ao islamismo pelas classes dirigentes dos reinos sudaneses, parece certo que, nos casos em que o apreço pela religião muçulmana era legítimo, as relações de comércio facilitaram o intercâmbio cultural e o contato com as crenças islâmicas por parte dos sudaneses. De qualquer forma, a proeminência desses interesses econômicos pode ser constatada na superficialidade que caracterizaria a islamização do Sudão até pelo menos o século XVI.

Essa superficialidade devia-se ao fato de que a penetração do Islã no campo foi pouco expressiva, e que a religião muçulmana não substituiu, no máximo coexistiu com as crenças animistas tradicionais das religiões africanas locais. $\mathrm{Na}$ verdade, a maior parte da população pouca consciência teve da "reforma religiosa" que se deu no reino de Gao. Além disso, mesmo as elites que adotaram abertamente e, inclusive, oficializaram o islamismo como religião de Estado manteriam as práticas tradicionais, visto que uma ruptura com elas poderia resultar na perda de prestígio junto ao povo. 


\section{O Surgimento do Islã em Gao}

Podemos ver como os interesses econômicos tiveram um papel importante na islamização desde o século XI. Quando seu décimoquinto governante, chamado Dia Kossoy, se converteu ao islamismo em 1009, a cidade de Gao estava se firmando como um importante entreposto comercial sudanês e ganhando cada vez mais importância em um cenário comercial mais amplo. O fato é que a conversão das classes dirigentes dos songais deu-se durante esse século, sendo esses governantes de Gao os primeiros soberanos negros a adotarem a crença islâmica.

Essa conversão, ainda que superficial, ligou o povo songai ao mundo muçulmano. Não só ao Magreb, mas também al Andaluz, como se pode constatar pela presença de estelas funerárias encontradas em Gao feitas no século XII na cidade de Almeria, situada na atual Espanha, à época sob domínio dos almorávidas. Entretanto, os songais seriam uma exceção na época, e o processo de islamização do Sudão estava apenas em seu começo, ainda muito pouco desenvolvido, sem qualquer intento da adoção de uma cultura muçulmana, nem de uma maior divulgação da religião.

No final do século XIII, os songais caíram sob o domínio do Império do Mali, passando a lhe pagar tributo. Sob a direção dos farin, ${ }^{2}$ os manden organizaram a região da Curva do Níger e encorajaram seu desenvolvimento econômico. Ainda que um período de dependência política, a época da dominação Mali representou um florescimento das cidades de Gao, importante centro econômico e administrativo, e de Tombuctu, centro espiritual e intelectual, que se tornou nesse período morada de diversos eruditos muçulmanos.

A conversão ao islamismo como uma estratégia diplomática para a inclusão do Sudão no mundo muçulmano foi uma prática comum no Império do Mali. Estabeleceu-se uma tradição segundo a qual os

\footnotetext{
${ }^{2}$ Funcionários do Império do Mali que atuavam como governadores das províncias.
} 
governantes deveriam fazer uma peregrinação à Meca, passando também pelo Egito, que teria função não só de oficializar e fortalecer a religião islâmica, que já fora constituída como religião de Estado, como também ampliar os contatos políticos com os governos muçulmanos, principalmente o egípcio, junto a quem os governantes sudaneses buscavam legitimação.

Essa política de diálogo com os países islâmicos atingiu seu auge durante o governo de mansa Mussa I. Ele fez de sua peregrinação à Meca um evento que serviu para a exibição e a ostentação de toda riqueza do Mali, levando consigo um número de servos e de riquezas, principalmente em ouro, que impressionou os egípcios, como pode ser notado através das crônicas que mencionam a passagem do imperador pelo Cairo, como os escritos de al-Umari.

A aproximação com as culturas islâmicas não se deu somente através dessa peregrinação, mas o mansa buscou ainda atrair, mediante a promessa de riquezas, poetas, artistas, juristas e sábios muçulmanos de todos os campos, como o poeta-arquiteto Abu Ishaq Ibrahim al Sahili, a quem alguns autores atribuem a construção das mesquitas de Tombuctu e de Gao. Além de mesquitas, também foram construídos diversos prédios públicos, na medida em que havia uma clara preocupação não só em tornar os pequenos vilarejos em grandes cidades, mas também tornar esses centros urbanos muito mais cosmopolitas, e devem muito a esse impulso cidades como Tombuctu e Djenne, as quais anos mais tarde se tornariam grandes centros urbanos (Silva, 1992).

\section{O Islã e o Sincretismo}

No final do século XIV, aproveitando a crise do império dos manden e seu próprio fortalecimento, o reino de Gao, sob a dinastia dos sonni, tornou-se independente e conseguiu expulsar os manden de seu território. Além disso, durante o governo de Sonni Madawu, os songais atacaram a própria cidade de Niane, capital do Império do Mali, pilhando-a e tomando 24 tribos de escravos pertencentes ao 
mansa. O próximo governante da linhagem, Sonni Solimão Daama, coordenou a invasão e o saque da cidade de Nema, povoada pelos soninquês. Porém, o apogeu da dinastia e a consolidação de um Império Songai deram-se, principalmente, pelas mãos de Sonni Ali Ber.

Sonni Ali (1464-1493) foi o governante que mudou o destino do reino de Gao, abandonando a política de pilhagem dos seus predecessores e adotando uma política de conquista e anexação territorial. Expandindo seu império para o Ocidente, conquistou Djenne e Tombuctu em 1468. A seguir, atacou também os mossis, os tuaregues e os dogons, tornando-se o soberano da Curva do Níger, agora unificada sob seu domínio, e eliminando a maioria das ameaças exteriores.

Sonni Ali encontrou forte oposição na aristocracia muçulmana, principalmente em Tombuctu. Era constantemente criticado pelos ulemás $^{3}$ de Sankore, que o descreveriam, dois séculos mais tarde, como um soberano cruel e tirânico. Os motivos desse enfrentamento do soberano com os sábios muçulmanos eram tanto de ordem ideológica quanto política. Ideológica porque havia sido educado no Faru (Sokoto) e teria sido apegado aos ritos tradicionais songais, nunca os abandonando, ainda que não necessariamente recusasse a religião islâmica. Politicamente, o conflito devia-se à aliança dos ulemás de Tombuctu com os tuaregues, inimigos políticos de Sonni Ali. Além disso, esses muçulmanos pregavam também um Estado conduzido estritamente pelas leis do Islã, condenando a preferência que Sonni Ali dava, aos seus olhos, aos cultos ancestrais e às estruturas de poderes tradicionais.

Decorrente desses conflitos entre as elites muçulmanas e o soberano, ganhou corpo um "partido muçulmano" que se aproveitaria da morte de Sonni Ali para se insurgir contra o poder. Sonni Baare, o descendente legítimo, recusou-se a se converter ao Islã, o que provocou uma guerra civil no império, da qual saíram vitoriosos os muçulmanos. Assim, Muhammad Sylla, com o título de askiya, tomou o poder e fundou uma dinastia muçulmana.

\footnotetext{
${ }^{3}$ Doutor da lei, conhecedor do Alcorão e da Suna muçulmana.
} 
Foi durante o governo do Askiya Muhammad (1493-1538) que o Islã tornou-se, de fato, o culto imperial. O imperador logo fez a peregrinação à Meca, legitimando seu poder na fé muçulmana. Os ulemás foram exaltados e postos a seu serviço, cadis $^{4}$ foram nomeados para as principais cidades, e as leis muçulmanas começaram a ser aplicadas. Tombuctu voltou à prosperidade e retomou seu prestígio de grande centro do saber.

Ao final do século XVI, as madrasas, escolas corânicas que se encontravam na "universidade de Sankore", o bairro ao redor da mesquita, somavam uma centena e meia. Alunos de toda faixa sudanesa iam para lá aprender o Alcorão, as leis islâmicas e a jurisprudência maliquita, e também história, geografia, gramática, lógica, retóri$\mathrm{ca}$, astronomia e astrologia. Na época do governo de Askiya Muhammad, o islamismo ganhou as cidades, irradiando de Tombuctu.

Durante o reinado do Askiya Dawud (1549-1583), o Império Songai conheceu seu apogeu, prosperando do ponto de vista econômico e ganhando notoriedade do ponto de vista intelectual, menos de duas décadas antes de seu declínio. Este governante também foi um grande mecenas, honrou os homens de letras e sábios, dando-lhes riqueza e prestígio, além de restaurar mesquitas.

Ao final do século XVI, já estava estabelecida nos grandes centros urbanos uma elite letrada muçulmana que reinterpretaria e adaptaria o Islã à realidade sudanesa. A universidade de Tombuctu, com suas diversas madrasas, desempenhou papel primordial na difusão da cultura islâmica no Sudão Ocidental. O direito maliquita foi implantado e prescrita a djibad (a guerra santa) contra os povos vizinhos conhecidos como mossi, considerados "infiéis".

Entretanto, deve-se considerar que essa cultura muçulmana e até a própria religião islâmica não chegaram ao campo, mesmo a essa época de uma islamização mais intensa. A própria religião dominante à época não foi o Islã, e sim as crenças tradicionais, os cultos an-

${ }^{4}$ Juízes. 
cestrais, as crenças animistas e nos curandeiros, os sonyanke, os quais tinham a função de proteger a sociedade contra os espíritos maléficos e os feiticeiros tirkei. Essas crenças pouco espaço acabaram cedendo ao Islã, mesmo em pleno século XVI (Cissoko, 1978), religião que ficou restrita aos grandes centros urbanos, onde habitavam os letrados e os sábios.

Para o Xeque Usuman Don Fodio (1754-1817), até a chegada dos europeus "o pensamento africano cultivava o amor de um Islã aberto para o universal que se distinguia muito nitidamente daquele observado no mundo árabe-muçulmano" (Cissoko, 1978). Suas palavras expressam muito bem a situação em que o Islã se encontrava no Sudão Ocidental até a época em que se deu a chegada dos europeus. O Islã era, sem dúvida, uma religião presente e influente, uma vez que passou a ser no governo de Askiya Muhammad a "religião de Estado" e a regular o funcionamento de seu governo. Mas era uma religião restrita principalmente aos reis e às elites urbanas, enquanto as populações rurais, provenientes de diversos grupos distintos, preferiam manter seus ritos tradicionais.

É importante perceber também que essa divisão entre uma elite urbana muçulmana e as populações agrícolas rurais e tradicionais não era, de forma alguma, dada arbitrariamente. Devido ao próprio caráter da religião muçulmana, que prega a tolerância religiosa e a aceitação, pelos povos tradicionais sudaneses, da existência de um ser superior (com a ressalva de apresentar diversos seres espirituais ligados às atividades cotidianas e ao espírito dos antepassados), é possível considerar certa forma de sincretismo, um islamismo permeado de crenças tradicionais, fenômeno religioso conhecido pelo nome de "Islã negro" (Monteil, 1964).

De acordo com Ricardo da Costa, os impérios formados ao sul do Saara teriam sido resultado "de um desenvolvimento autóctone bastante recuado (e de natureza pagão-animista), iniciado provavelmente na Era Cristã, aliado ao avanço berbere-islâmico em direção ao sul do Saara no século IX". Isso muito nos diz a respeito da formação religiosa, que, além 
de abarcar a fé islâmica e crenças tradicionais, produziu uma relação entre elas, conferindo caráter específico à religião praticada na região do Sudão Ocidental. A própria arquitetura congrega elementos sincréticos, originais. As mesquitas, construídas com argila, seguem o padrão das construções sudanesas, mas apresentam elementos influenciados pela decoração islâmica.

\section{As Crenças Songais}

Mesmo antes de se tornar um império, o Songai não era constituído de um povo único, pois em seu território havia dezenas de outros povos, destacando-se os manden, os soninquês, fulas, tuaregues, bareba, mossis, dogons, entre outros, além dos próprios songais. Esses povos eram distintos quanto às formas religiosas e culturais, mas apresentavam algumas semelhanças, como os modos de subsistência, sendo principalmente pescadores-cultivadores, embora alguns também eram caçadores (Mauny, 1970).

A aceitação do Islã dentro do Império Songai não foi unânime. Alguns reis convertiam-se ao Islã, enquanto outros não o faziam. Podese pensar que a escolha do governante pela religião de Maomé não exercesse tanta influência na adesão da população à fé islâmica. Até mesmo quando o islamismo foi considerado "religião de Estado", ficando a administração nas mãos de governadores de províncias, e a justiça nas mãos do cadi, decisões eram freqüentemente tomadas segundo os preceitos próprios dos grupos, e a justiça era feita dentro da própria comunidade, sem consulta ao cadi-apesar de nessa região ele ser até hoje alguém muito respeitado e influente.

Os povos incorporados ao Império Songai tinham suas próprias crenças, rituais e práticas religiosas. Convém, entretanto, lembrar as reflexões de H. Deschamps (1962), para quem era possível encontrar em todos aqueles povos a existência de um Deus supremo, geralmente tido como o criador, como o Amma, dos dogons. 
O trabalho de Deschamps data do século XX, e pode-se pensar em ao menos duas possibilidades para a existência da divindade suprema: a primeira se refere à incorporação do Deus único dos muçulmanos na prática religiosa desses grupos; a segunda, à existência da crença em um Deus único antes mesmo da chegada dos muçulmanos, mas com presença de deuses secundários como mensageiros do deus principal. A segunda possibilidade parece obter maior respaldo, visto que o povo dogon, como muitos outros, não aderiu ao islamismo, em favor de suas tradições. Assim, é possível que a adoção do Islã tenha ocorrido parcialmente porque, com o preceito de Deus único, não causasse, de fato, tanto estranhamento entre os sudaneses.

A propósito, a religião dos muçulmanos aceita a existência de "demônios", os djins (Burlot, s/d) e, de maneira semelhante, entre os dogons e os manden existem gênios que podem causar enfermidades, que são os provocadores da morte, que são ladrões (Deschamps, 1962). Desse modo, a aceitação do Islã não alterava essencialmente os traços religiosos até então existentes. Por aqui se pode vislumbrar outro aspecto da relação entre islamismo e religiões tradicionais: enquanto que os dogons, apesar de possuírem certa semelhança nesse ponto com o Islã, preferiram conservar suas crenças tradicionais, talvez pela sua forte organização social e religiosa, os manden se islamizaram. Daí se pode inferir que condições de coesão social, religião e outros fatores preexistentes contribuíram para a efetiva islamização ou a permanência das crenças tradicionais.

A conquista de fiéis ao Islã se deu por vezes de forma violenta, com a anexação militar de territórios, mas geralmente era conseqüência da circulação de idéias promovida por mercadores muçulmanos e viajantes, de maneira pacífica e lenta. Os primeiros indícios arqueológicos de efetiva islamização na região que posteriormente constituiria o Songai são as inscrições tumulares em pedra, conhecidas como Epitáfios de Gao, feitas entre 1100-1265 no cemitério real (Mauny, 1970).

O aparente sucesso do Islã deve algo à simplicidade da doutrina islâmica, bastando a profissão de fé, a Sha'ada, para a conversão. 
A idéia da unicidade de Deus, como vimos, não era plenamente estranha aos sudaneses. A escrita dos muçulmanos causava boa impressão entre os sudaneses, por ter de certo modo um caráter mágico e de extremo poder. As letras do Alcorão, ou passagens do Alcorão, vieram a ser utilizadas como uma espécie de talismã em rituais ou como remédio para diversas doenças, dentre outras funções.

Há que se observar, entretanto, que as populações rurais não aceitaram com facilidade a "nova" religião (Cissoko, 1978). Diversos fatores explicam tal resistência, entre eles, a maior coesão interna dessas populações, as quais preferiram seguir seus costumes baseados em direitos, posse de terra, ritos e justiça consuetudinários, ao invés de abraçar uma fé que provavelmente mudaria algumas práticas (Deschamps, 1962). O fato é que as populações rurais eram mais apegadas aos rituais de fertilidade do solo, que pudessem prover a terra de chuvas, o afastamento de pestes e a conservação da prática agrícola, o que se liga, dessa forma, às atividades que exerciam. Essa, portanto, pode ter sido uma das razões da menor adesão do Islã entre os habitantes das aldeias.

Por outro lado, é importante observar as práticas sincréticas que emergiram da interpenetração das religiões sudanesas tradicionais e o islamismo. Caracterizadas pela forte sacralização de elementos da natureza e pela realização de ritos mágicos, as crenças sudanesas possuíam ampla ressonância coletiva.

Precisamente no caso do Songai, há exemplos de sincretismo, de aceitação e imposição do Islã e das crenças tradicionais. A própria lenda de origem do império conta que o feiticeiro Faran Makan Bote, filho de pai soko e mãe-fada ligada ao espírito das águas, subiu o rio e ali se aliou aos caçadores gows e pescadores sorkos, tornando-se o grande sacerdote (Kanta). Assim teriam nascido as energias mágicas do Songai. Por volta do ano 500, berberes teriam chegado à Curva do Níger e libertado pescadores sorkos e camponeses gabibis do peixe-feiticeiro descendente de Makan Boté. O chefe dos berberes seria Za-Aliamen, cuja dinastia dominou até 1335 em Kukya. Ele teria sido antepassado 
direto de Dia Kossoy, o primeiro rei songai convertido ao islamismo. Não deixa de ser interessante a situação: um rei muçulmano justificando sua origem dinástica numa lenda extraída das crenças tradicionais.

$\mathrm{O}$ sincretismo manifestou-se até mesmo nas cerimônias reais. Após o período de governo de Askiya Muhammad, no dia da entronização de cada novo imperador, este recebia um selo, uma espada e um Alcorão, conservando dois atributos mágicos antigos: o tambor e o fogo sagrado (dinturi). Havia também as funcionárias feiticeiras, que poderiam, inclusive, se dirigir ao imperador pelo nome, e o sacerdote do culto aos antepassados (Costa, s/d).

Também em Tombuctu parece ter prevalecido esse clima de efervescência religiosa. No século XVI, Ahmed Baba (1556-1620), um dos chamados Eruditos de Tombuctu, ensinava os principais ramos do saber com base nos estudos islâmicos: a língua árabe, retórica, exegese corânica e jurisprudência. Foi se constituindo na cidade um corpus filosófico, jurídico e religioso, através da transcrição por copistas das conferências dos ulemás. O cronista Mahmud Kati, no Tarikh al-Fattash, fez o elogio maior da grande cidade:

Tombuctu era diferente de todas as demais cidades dos negros, por causa da solidez de suas instituições, a liberdade política, a pureza dos costumes, a segurança das pessoas e dos bens, a clemência e a compaixão para com os pobres e estrangeiros e o tratamento dispensado a estudantes e cientistas (Djian, 2004).

Atualmente, os povos songais vivem nos atuais países do Mali, Senegal, Níger, Burkina Fasso, Benin e Nigéria. A maioria da população é considerada islâmica, e, além disso, o vestuário, o calendário e as leis civis são islâmicos. Entretanto, nos locais mais longínquos, as religiões tradicionais suplantam o islamismo. O sincretismo e a convivência das religiões ainda estão presentes, pois, mesmo existindo os festivais nos quais os songais fazem oferendas aos espíritos para controlar as pestes (o chamado hori) e a conhecida dança da chuva (yenaandi), é possível encontrar os "clérigos" islâmicos, os marabutos. 


\section{Referências}

BURLOT, J. A Civilização Islâmica. Mem Martins, Europa-América, s/d. CISSOKO, Sékéné Mody. O Songhai do século XII ao XVI. In: Djibril Tamsir NIANI (Org.). História Geral da África. São Paulo: Editora Ática, 1978. Vol. 4: A África dos séculos XII ao XVI.

COSTA E SILVA, Alberto da. A enxada e a lança: a África antes dos portugueses. São Paulo: Editora Nova Fronteira/ EDUSP, 1992.

COSTA, Ricardo da. A expansão árabe na África e os impérios negros de Gana, Mali e Songai (séculos VII-XVI) (Disponível on-line em: www.ricardocosta.com) (Acessado em 27/06/2007).

DAVIDSON, Basil. À descoberta do passado de África. Lisboa: Sá da Costa Editora, s/d.

DESCHAMPS, Hubert. Las religiones del Africa negra. Buenos Aires: Editorial Universitária de Buenos Aires, 1962.

DJIAN, Jean-Michel. A Africa redescoberta. In: Le Monde diplomatique (Brasil), agosto de 2004 (Disponível on-line em: http://diplo.uol.com.br/imprima970 (Acessado em 26/06/2007).

JOMIER, Jacques. Islamismo: história e doutrina. Petrópolis: Vozes, 1992.

MAUNY, Raymond. Les siécles obscurs de l'Afrique noire. Paris: Fayard, 1970.

MONTEIL, Vincent. L'Islam noir. Paris: Éditions du Seuil, 1964. 
6

\section{A ESCRAVIDÃO ENTRE \\ OS POVOS DO SUDÃO OCIDENTAL: \\ SÉCULOS VII-XVI}

\section{Diego Schwalb Zanoto}

O objetivo deste texto será discutir, brevemente, o papel econômico e social da instituição da escravidão nos reinos ou impérios africanos de Gana, Mali e Songai.

Poderíamos situar cronologicamente esses Estados como pertencentes ao período "medieval", mas entendemos que o conceito de "Idade Média" foi proposto com base em um olhar eurocêntrico da História, o que nos leva a procurar evitar utilizá-lo fora de um contexto europeu.

Em todo caso, é entre os séculos VII e XVI da era cristã que a instituição da escravidão se desenvolve consideravelmente na África Ocidental. No decorrer do texto, procuraremos analisar a importância e o espaço do cativo dentro das diversas instituições que compõem os Estados sudaneses citados anteriormente, bem como o grau de dependência das estruturas sociais, econômicas e políticas, com relação à figura do trabalhador escravizado.

\section{Escravidão e Sociedade no Sudão Ocidental}

As relações de escravidão no Sudão Ocidental (parte mais a oeste do que em árabe foi chamado de Bilad al-Sudan, a "terra dos negros") parecem começar a se desenvolver, principalmente, a partir dos primeiros contatos entre as populações nômades do deserto com os povos se- 
dentários da região do Sahel (estepes e savanas ao sul do Saara e ao norte das florestas tropicais), embora, como veremos adiante, possivelmente um tipo de escravidão de linhagem já fosse praticado entre estes povos.

Entre o século I e o século III da era cristã, o camelo é introduzido no deserto do Saara, e as tribos berberes iniciam um processo de expansão por este deserto, tomando conta dos oásis e estabelecendo rotas comerciais. Esses nômades pilhavam os povoados dos arredores do deserto e mesmo os que habitavam os oásis, muitas vezes transformando em cativas as populações saqueadas. Tanto na região do Magreb quanto na do Sahel, isso ocorreu constantemente (Costa e Silva, 1996, p. 267).

Logo aumentaram os contatos entre as populações sedentárias das savanas ao sul do Saara (ligadas ao cultivo da terra, à criação de animais, à coleta e à pesca) e as tribos nômades do deserto (pastoras e caçadoras). Desses contatos poderiam nascer relações de amizade ou conflito, de comércio pacífico ou de saques. E a escravidão começava a fazer parte dessas estruturas, porém, inicialmente, de forma marginal. A redução de um indivíduo à situação de escravidão era algo incidental, não estava na base da produção econômica.

Em grande parte da África Ocidental, a estrutura social era baseada nas relações étnicas e de parentesco, tanto nos clãs dos povos nômades quanto nas famílias dos sedentários, fossem criadores de gado, agricultores ou pescadores. Constituíam, assim, formações sociais comunitárias, base de um modo de produção de linhagem (Lovejoy, 2002, p. 43), no qual não existiam antagonismos de classe, sendo que as divisões sociais fundamentais eram aquelas relacionadas, por exemplo, ao gênero ou à idade. Quer dizer, se existiam escravos, eles não formavam uma classe social distinta, pois, além de estarem em pequeno número, trabalhavam nas mesmas tarefas exercidas pelos membros da família ou linhagem. Ou seja, não havia um modo de produção escravista, uma vez que a escravidão não constituía a base da produção.

Os escravos poderiam tornar-se, aos poucos, membros do grupo familiar, visto que quanto maior o grupo social, maior seria a influ- 
ência política e o poder desse grupo (Lovejoy, 2002, p. 44). Entretanto, o escravo, visto como uma mercadoria, poderia exercer somente aquelas funções para as quais era designado. Assim, as tribos nômades do Saara poderiam levar cativos para trabalhar nos oásis, no cultivo de cereais e tâmaras (Costa e Silva, 1996, p. 270), ou poderiam utilizá-los junto às populações sedentárias subjugadas. $\mathrm{O}$ escravo, aos poucos, também foi se fazendo presente nos trabalhos mais pesados, como, por exemplo, na extração mineral. Grande parte dos povos do Sudão Ocidental conhecia, há muito tempo, o ferro, o qual era utilizado amplamente na fabricação de armas e de utensílios ligados ao cultivo agrícola; o sal era extraído de minas no Saara; o ouro era trazido das regiões mais meridionais, principalmente através do comércio com as populações que lá habitavam e que lá mesmo extraíam o precioso metal: em todos esses casos, o trabalho escravo era utilizado.

Os nômades do Saara, muitas vezes, acabaram se impondo sobre as populações do Sahel como uma nobreza de senhores guerreiros, legitimados pela força e/ou pelo costume, embora as características normativas desse poder permanecessem de acordo com os costumes das comunidades agrícolas sedentárias (Costa e Silva, 1996, p. 271), cujas estruturas eram mais sólidas do que a dos nômades, e estes acabaram tendo que se adequar a elas. Ao mesmo tempo, muitas aldeias próximas ao Saara estavam se transformando em grandes centros comerciais, devido ao estabelecimento definitivo das rotas comerciais transaarianas e das relações da África negra com outras partes do mundo. Cidades como Audagost e, futuramente, Ualata acabaram se tornando verdadeiros portos caravaneiros, e novas relações de poder e riqueza começaram a se estabelecer.

\section{Islamização e Tráfico de Escravos}

Na medida em que as rotas e os centros comerciais se desenvolviam, escravos passavam a ser cada vez mais exportados para o norte da 
África e para o Oriente Médio. De fato, as mercadorias mais importantes (e mais antigas) do comércio transaariano eram o escravo, o ouro e o sal (Costa e Silva, 1996, p. 273). Inicialmente, escravos eram requisitados para trabalhar nos oásis e nos canaviais da África mediterrânica. Com o nascimento e a expansão do Islã, a partir da Arábia, no século VII, a escravaria foi se tornando cada vez mais essencial para os nascentes reinos muçulmanos. Os cativos, então, eram requisitados para as mais diversas tarefas, desde fazer parte dos haréns até servir no exército.

A escravidão na África se intensifica consideravelmente na medida em que o Islã vai se expandindo. As cortes faustosas dos reinos muçulmanos precisavam, sobretudo, de escravas, seja para compor o harém, seja para fazer os serviços domésticos palacianos ou mesmo para trabalhar na agricultura. Meninos ou pré-adolescentes também são muito requisitados, com vistas a serem educados militarmente a fim de integrar o exército (Costa e Silva, 2002, p. 54). Esse tipo de força armada, classificada por Van Den Berghe (1966, p. 112) ${ }^{1}$ como "Força Palaciana", na qual os soldados são geralmente mercenários e escravos, enquanto os oficiais são membros da nobreza, também existirá nos impérios sudaneses de Gana, Mali e Songai. Além disso, há uma grande procura por eunucos, seja para que cuidem de funções administrativas, seja para montar guarda nos haréns. Os homens adultos eram os escravos mais baratos do mundo muçulmano, sendo destinados às tarefas mais trabalhosas.

Nas sociedades islâmicas, a escravidão não era uma instituição que se autoperpetuava. Os filhos de escravos eram geralmente assimilados pela sociedade, sendo substituídos por novas importações (Lovejoy, 2002, p. 48). Não existia uma classe distinta de escravos, com consciência própria, pois eles exerciam as mais diversas atividades, provinham das mais diversas etnias e regiões (poderiam provir, além da África subsaariana, da Europa Ocidental, do sul da atual Rússia, do

\footnotetext{
${ }^{1} \mathrm{O}$ autor identifica seis tipos de forças armadas presentes através de toda a história do continente africano: Milícias Civis de Incursão, Forças Palacianas, Forças Armadas de Golpe, Forças Civis Revolucionárias, Forças de "Herrenvolk" e Forças Coloniais.
} 
Oriente, do Norte da África...) e muitas vezes acabavam incorporados à sociedade muçulmana.

De comum entre eles havia o fato de que todos eram (ou deveriam ser) "pagãos", pois um muçulmano não poderia escravizar outro da mesma crença. Por isso, os cativos vinham das regiões de fronteira do Islã, e cada vez em maior quantidade. Todavia, a exportação de escravos da África subsaariana para o mundo muçulmano ou para qualquer outro local, embora fosse muito importante economicamente para o futuro surgimento dos reinos sudaneses, foi relativamente modesta até o século XV e praticamente não se expandiu até o século XIX (Lovejoy, 2002, p. 49). As exportações eram de poucos milhares de escravos por ano, os quais vinham de regiões muito extensas, fazendo com que não houvesse, inicialmente, um impacto local importante.

É preciso ressaltar que, posteriormente, à medida que os Estados de Gana, Mali e Songai foram se estruturando e se constituindo, e que o Islã foi penetrando cada vez mais nas sociedades sudanesas (a ponto de se tornar, em certa época, a religião oficial e a base da lei), mais se estreitaram os laços entre a religião islâmica e a escravidão. Esse aspecto será abordado com mais detalhe no decorrer do texto.

\section{A Escravidão em Gana}

O tráfico de escravos através do Saara tornou-se, certamente, um dos fatores preponderantes na consolidação dos primeiros reinos do Sudão Ocidental, seja através do controle das rotas comerciais, seja através da organização de ataques que visavam à obtenção de escravos para a venda. Porém, mais do que escravos, pelas rotas transaarianas é que chegava ao mundo boa parte do ouro que se conhecia. Certamente, controlar os portos caravaneiros por onde escoava este ouro significava ter o controle, por meio de tributos, de todo comércio da região, o que gerava poder e rendas conside- 
ráveis. Foi o que aconteceu a partir dos séculos IV ou $\mathrm{V}$ com as populações de etnia soninquê, cujos povoados localizados na orla setentrional do Sahel se unificaram em torno de uma dinastia soberana, fundando o reino de Gana.

É importante salientarmos o que se quer dizer quando se aplicam conceitos como "reino" ou "império" dentro do contexto da África antes da expansão européia. A formação estatal que parece ser a mais comum no Sudão Ocidental (e provavelmente em boa parte do continente africano) é o que se pode chamar de chefatura, na qual existe um rei que controla diretamente, sem uma corte ou qualquer tipo de corpo de funcionários, uma determinada área ou determinadas aldeias e tribos. Quando se fala em controlar, significa que os povos subjugados reconhecem a autoridade do rei ou chefe, pagando algum tipo de tributo ou enviando homens para ajudar na guerra. Ou seja, não existem demarcações territoriais claras. Já um reino, nesse contexto africano, é uma organização estatal que conta com um corpo de funcionários que administram um território mais vasto, sob o comando de um soberano (geralmente o título do soberano era o nome pelo qual se identificava o território, como, por exemplo, o próprio caso de Gana), embora também não existam fronteiras exatamente determinadas. Enfim, se falarmos em império, poderíamos ter, nesse caso, um reino que se impõe a outros reinos, mas não por meio de leis unificadas ou de fronteiras territoriais exatas (como, por exemplo, o Império Romano), e, sim, através do pagamento de tributos e do reconhecimento da autoridade por parte dos subjugados.

Portanto, não existiu uma estrutura política sólida dentro do território do reino de Gana - chamaremos aqui Gana de reino, pois, segundo Costa e Silva, esse território era praticamente um "estado nacional" dos soninquês, uma esfera de influência através da qual o gana exercia sua soberania por meio de relações entre os diversos grupos ou linhagens, as quais forneciam ao soberano tributos, soldados, funcionários para a corte e lavradores (Costa e Silva, 1996, p. 277), escravizados ou não - , sendo que cada aldeia, tribo ou cidade se relacio- 
nava com o soberano e entre si de acordo com seus próprios costumes. Gana se organizava principalmente a partir da cidade de Kumbi Saleh, e o seu auge se deu nos séculos IX e X, com a conquista da importante cidade comercial de Audagost. Entretanto, desde o século VIII os muçulmanos já relatavam a existência de Gana como "o país do ouro".

O reino de Gana tinha como principais adversários os reinos ou as chefaturas vizinhas, os quais lutavam pela hegemonia da região (como Takrur, a oeste, ou Gao, a leste), e as tribos berberes (principalmente os grupos azenegues), que atacavam constantemente os portos caravaneiros. O principal trunfo comercial de Gana era manter o controle da exportação do ouro (proveniente, fundamentalmente, das minas de Bambuk, na região de Wangara) e da importação do sal (originário, principalmente, das salinas de Tagaza, no Saara). Gana era um reino não-muçulmano, embora existissem, nas principais cidades, bairros específicos para mercadores muçulmanos, muitos dos quais acabavam se tornando também funcionários do Estado.

Com relação à escravidão no reino de Gana, poderíamos, a princípio, afirmar que os escravos eram, na verdade, um produto de luxo destinado principalmente à exportação. Mas também há indícios de que eles eram, junto com os camelos, os principais carregadores de mercadorias através das rotas transaarianas. Eles eram comprados na mesma região meridional de onde saía o ouro, assim como a goma e o marfim (Ki-Zerbo, 1972, p. 141), e eram levados aos mercados do norte. Há evidências de que já existiam expedições para a captura de escravos, levadas a cabo por chefes vassalos do gana (Costa e Silva, 1996, p. 281). O grande geógrafo muçulmano al-Idrisi comenta, no século XII, que habitantes dos reinos de Gana e Takrur organizavam ataques-surpresa a povos "pagãos" com o único intuito de fazer prisioneiros para vendê-los como escravos (Niane, 1978, p. 145).

O reino de Gana contava com um numeroso exército. Os escritores muçulmanos fornecem a cifra, provavelmente exagerada, de que 
era integrado por cerca de 200 mil homens (Ki-Zerbo, 1972, p. 147). A informação apenas serve como parâmetro para a grandiosidade e o poder deste reino, que contava com arqueiros e cavaleiros sem sela, além da infantaria. Possivelmente escravos também fizessem parte desse exército, ou pelo menos da guarda real. O escritor al-Bakri, ao narrar as pomposas audiências entre o soberano e os súditos, afirma que atrás do gana havia uma fileira de dez escravos, com espadas e escudos ornamentados de ouro (Costa e Silva, 1996, p. 281).

No século XI, a expansão dos almorávidas atinge Gana, e cidades importantes como Audagost e Kumbi Saleh são impiedosamente saqueadas. Gana perde sua hegemonia e seu prestígio, apesar de ainda ser considerado um reino, porém agora de menor porte. No século XIII, é a vez dos sossos, vindos do sudeste, invadirem Gana. Entretanto, Kumbi Saleh continua sendo uma cidade importante por mais um ou dois séculos, enquanto muitos mercadores soninquês emigram para Ualata, a qual, após o declínio de Audagost, se tornará o mais importante porto caravaneiro da região (Costa e Silva, 1996, p. 291).

\section{Os Cativos no Império do Mali}

O Império do Mali pode ser caracterizado como uma confederação dos povos e reinos de origem manden ou mandinga, constituído a partir do ano de 1235, sob o comando de Sundjata Keita, considerado o herói fundador desse poderoso Estado. Na luta contra a hegemonia do reino Sosso, governado por Sumaoro Kante, Sundjata acaba fundando o que se tornará o primeiro grande império muçulmano da África Ocidental, cujo apogeu se dará entre meados do século XIII e o fim do século XIV.

As relações entre a expansão do Islã e a escravidão já se faziam presentes no Sudão Ocidental, e eram muito importantes nesse contexto de surgimento do Império do Mali. O rei dos sossos, Sumaoro Kante, é descrito pelos griôs como um rei cruel e impiedoso, além de 
ser dotado de poderes mágicos (Niane, 1978, p. 144); isso, porém, pode se dever ao fato de que ele era, além do mais, um feroz adversário do Islã. Nessa condição, consta que Sumaoro Kante lutava para suprimir o tráfico de escravos exercido por alguns grupos soninquês (Niane, 1978, p. 144), possivelmente islamizados ou em vias de islamização. E isso foi visto pelos habitantes do Manden como mais um dos excessos deste soberano, o qual deveria ser combatido e vencido. Sundjata Keita vence os sossos, e, depois dele, todos os mansa - título dos soberanos do Mali, que significa algo como "imperador" ou "rei dos reis" (Niane, 1978, p. 152) - da dinastia Keita serão muçulmanos. Esses fatos podem servir como exemplo de que no antigo mundo muçulmano, e aí se incluem também os impérios do Mali e de Songai, a escravidão era vista como algo natural, senão essencial.

Aliás, exemplos nesse sentido não faltam. No século XV, já no contexto do Império Songai, o jurista Al-Maghili é bastante claro em sua recomendação ao askiya Muhammad: é dever do muçulmano fervoroso "fazer a guerra santa contra os infiéis, matar-lhes os homens, escravizarlhes as mulheres e as crianças e tirar-lhes todas as riquezas" (Costa e Silva, 2002, p. 32). Sobre essa certa necessidade de mulheres e crianças ou pré-adolescentes, já falamos anteriormente. Mas é interessante notarmos que, além de abastecer o comércio transaariano, os escravos agora também surgem como produtos da "guerra santa".

O auge do Império do Mali se dá no governo de Mansa Mussa I (de 1307 a 1332). Nessa época, o Mali se torna conhecido como o maior exportador de ouro do mundo, e a fama de Mussa e seu império se espalha por todo o mundo muçulmano, inclusive até pela Europa. Ele aparece, em 1339, num mapa-múndi catalão como o Rex Melli, e também está desenhado segurando uma pepita de ouro, no chamado Atlas Catalão de Carlos V, de 1375, feito pelo judeu Abraão Cresques (Costa, 1996, p. 329). Toda essa fama se deve, sem dúvida, a muito comentada visita que fez ao Cairo em 1324, no caminho da peregrinação à Meca. Acompanhado por um séquito composto por milhares de pessoas, consta que ele distribuiu e gastou tanto ouro nesta 
cidade, que o precioso metal ficou desvalorizado (Niane, 1978, p. 167). Entre as pessoas que o acompanhavam, estavam quinhentos escravos, todos carregando ouro em suas mãos (Heers, 1983, p. 79). O escravo mais uma vez aparece, então, como um objeto de ostentação, demonstrando o luxo da corte e o poder do soberano.

E o trabalho escravo, inserido nesse movimento de consolidação do Império do Mali, parece ter se tornado cada vez mais indispensável, ao menos em algumas áreas. Por exemplo, na mineração: no auge da expansão territorial, o Mali - que poderia ser considerado um dos maiores Estados mundiais de seu tempo (Davidson, 1977, p. 102) - englobava desde as minas de sal de Tagaza, no Saara (limite norte do império), até as minas de cobre de Takkeda (que também era um porto caravaneiro importante nos limites a leste), incluindo as minas de ouro de Bambuk (ao sul, numa região mais próxima à capital, Niane); em todos esses lugares, o trabalho escravo se fazia absolutamente presente.

Com relação a Takkeda, o famoso viajante Ibn Battuta comenta na metade do século XIV que, nas minas de cobre, trabalhavam tanto homens como mulheres (Ibn Battura, 1987, p. 790). Também eram escravos grande parte dos carregadores que cruzavam as rotas comerciais: os comerciantes Wangara, próximos do Atlântico, chegaram a possuir, no século XV, mais de 200 escravos, os quais transportavam sal (que seria trocado com os povos da floresta por ouro) das minas do norte até o sul. Também existiam cativos cuidando da administração estatal, muitas vezes ligados diretamente ao soberano, como era o caso, por exemplo, do santigui, "senhor do tesouro", uma espécie de ministro das finanças (Niane, 1978, p. 183). O geógrafo al-Umari descreveu que na corte do mansa eram utilizados, inclusive, escravos turcos, ou seja, não-negros.

Mas não nos enganemos. Tudo indica que, no Mali, a importação de escravos era algo pequeno, quase uma exceção; fazia parte do costume muçulmano constituir uma guarda real de escravos eunucos ou mercenários estrangeiros, para assim evitar o surgimento de uma 
nova casta nobre, proveniente do próprio país, a qual porventura viesse a competir pelo poder. No que diz respeito ao exército, é interessante notar que tropas escravas só começaram a aparecer no final do império, visto que, durante o seu apogeu, contingentes de homens livres, vindos de todas as províncias, eram regularmente integrados às forças armadas (Niane, 1978, p. 183).

Ibn Battuta, que como boa parte das pessoas de sua época via a escravidão como algo natural, nos mostra que os escravos estavam integrados na sociedade do Mali, seja servindo na corte do mansa, seja como propriedade de pessoas mais ricas. Nesse último caso, Battuta relata que, entre outros feitos, era comum mandar os escravos, nas madrugadas de sexta-feira, guardar o lugar dos amos nas mesquitas, visto que elas ficavam lotadas de fiéis, e muita gente não conseguia entrar para fazer as orações (Ibn Battuta, 1987, p. 783-784).

O Mali começou a decair, como Império, a partir de duas frentes. No interior, muitas províncias e tribos passaram a se rebelar e o poderio do Estado se enfraqueceu, perdendo, inclusive, o controle sobre as rotas caravaneiras. No litoral, durante o século XV, os portugueses começavam a entrar em contato com as províncias mais a oeste, iniciando uma demanda e o conseqüente fomento de um tráfico mais intenso de escravos. Na verdade, os portugueses se deram conta das diversas possibilidades de comércio na região. Por exemplo, eles compravam cavalos do povo futa para revendê-los no Gâmbia (Mali ocidental), e a moeda eram os escravos (Ly-Tall, 1978, p. 196). Inclusive genoveses, no decorrer do século XV, começaram a entrar no tráfico de cativos africanos (visto que já existia, no mundo europeu mediterrânico, um tráfico relativamente bem desenvolvido de escravos - sem comparação, claro, com a intensidade da escravidão que existirá na América -, provenientes dos povos eslavos ou do mundo muçulmano). O cronista português Diego Gómez lamentou-se, em seus escritos, de que os genoveses faziam uma concorrência desleal, pois aceitavam trocar um cavalo por somente seis negros, enquanto o preço mais comum era o de quatorze negros (Heers, 1983, p. 80). 


\section{Escravos no Império Songai}

Um dos agentes da desestruturação do Mali foi o reino Songai, que tinha em Gao a sua principal cidade. Por volta dos séculos XI ou XII, os soberanos e nobres do Songai já estariam, ao menos superficialmente, convertidos ao Islã (Ki-Zerbo, 1972, p. 182). A luta desse reino contra a dominação malinense terá como resultado, justamente, a dominação do próprio Songai sobre todas as províncias do Mali, e ainda mais além. Sob o reinado do conquistador Sonni Ali (14641493), o Songai impõe-se como um império a toda região do Sudão Ocidental. Em 1496, Askija Muhammad fez uma faustosa peregrinação à Meca (lembrando a que fez Mansa Mussa) e conseguiu o reconhecimento de Songai como um Império dentro do mundo muçulmano. Assim como Mansa Mussa, ele também atraiu sábios ao seu país e incentivou a produção intelectual, sobretudo através dos estudiosos de Tombuctu.

Entre os maiores inimigos do Império Songai, estava o povo mossi, do sul. Seu rei era inimigo do Islã e não aceitava a conversão e a submissão aos songais. Quando intimado por Askiya Muhammad a se converter, o soberano Mossi respondeu, de uma forma que pode ser interpretada como irônica e provocativa, que precisava primeiramente fazer sacrifícios aos seus antepassados para lhes solicitar um parecer (Ki-Zerbo, 1972, p. 185). Mossi e Songai possuíam um exército estruturado, e as agressões só cessaram quando, no final do século XVI, o expansionismo de Marrocos subjugou o Império Songai e boa parte do Sudão Ocidental.

Assim como no Mali, os escravos exerciam um papel importante na sociedade e na economia de Songai. Quando a cidade de Niane, antiga capital mandinga, foi tomada e saqueada pelo pai de Sonni Ali, consta que fazia parte do butim vinte e quatro tribos de escravos que residiam na cidade e eram propriedades do mansa (Cissoko, 1978, p. 209). Aliás, a maior diferença entre o Mali e o Songai consistia no fato de que o segundo era um império com coloração moderna, uma vez 
que sua estrutura era rigidamente organizada e sua monarquia possuía um caráter centralizador e absolutista (Cissoko, 1978, p. 215). Havia na corte de Gao setecentos eunucos à disposição do monarca, enquanto inúmeros escravos realizavam as mais diversas tarefas domésticas no palácio, dirigidos por um funcionário real que atuava como uma espécie de mordomo-mor, chamado bu horokoy koy (Cissoko, 1978, p. 215).

Os escravos também engrossavam as fileiras do exército. Além de serem moeda de troca para a compra de cavalos (a cavalaria, entretanto, era constituída majoritariamente por uma elite de nobres), os escravos eram a massa da infantaria do exército songai. A grande maioria desses escravos era propriedade pessoal do askiya, e o soberano lhes herdava todos os bens e tinha o direito de desposar suas filhas (Cissoko, 1978, p. 219). Os cativos que compunham o exército provinham, principalmente, dos exércitos dos reinos vencidos durante a expansão songai. Dentro das forças armadas, o escravo podia até ascender socialmente, por bravura e competência. Muito famosos em Songai eram os regimentos de eunucos a cavalo (Costa e Silva, 1996, p. 553) .

No mundo rural, já começavam a aparecer escravos na produção. As terras do soberano, no vale do Níger, eram cultivadas por verdadeiras comunidades de escravos, sob a direção de capatazes os fanfa (Cissoko, 1978, p. 220). Também eram cobrados impostos sobre os escravos de particulares. O escravo também consistia num dos principais produtos de exportação, assim como o ouro, a nozde-cola, especiarias, o marfim e o algodão. Entretanto, a principal moeda de troca parecia ser mesmo o sal (Cissoko, 1978, p. 222).

Embora tenham surgido cidades bastante desenvolvidas, a massa da população de Songai vivia no campo. A sociedade deste Estado era caracterizada por uma rígida hierarquização: nobreza (dedicada à administração e ao comando militar), homens livres, membros das castas (que designavam ofícios específicos, como ferreiros, pescadores, etc.) e, por último, escravos, os quais eram bastante numerosos, seja no cam- 
po ou na cidade (Cissoko, 1978, p. 223). A origem dos escravos eram os povos vencidos, geralmente aprisionados de forma truculenta (Costa e Silva, 1996, p. 557). A cidade de Gao tinha um importante mercado de escravos, os quais eram destinados principalmente a trabalhar no mundo mediterrânico. Depois de atravessar o Saara, eram vendidos a bom preço tanto para cristãos quanto para muçulmanos.

O Império Songai representava o auge de um processo de expansão e complexificação estatal, de penetração da fé muçulmana e de interação comercial mais intensa entre a África subsaariana Ocidental e o mundo mediterrânico. Quanto mais se desenrolava esse processo, mais aumentava a demanda externa e interna por escravos. Paradoxalmente, ao mesmo tempo em que se constituíram impérios unificados, essa demanda por cativos fazia recrudescer as guerras entre os povos, reinos e tribos africanas (Heers, 1977, p. 43). A expansão de Marrocos sobre os territórios subsaarianos, por um lado, e a expansão européia (principalmente portuguesa) pressionando a partir do Atlântico, por outro, fizeram a decadência do Império Songai, o último grande Estado do Sudão Ocidental.

\section{Considerações Finais}

Na região do Sudão Ocidental, entre os séculos VII e XVI, a escravidão passou a cada vez mais fazer parte, de maneira notável, das instituições sociais e econômicas dos povos, reinos e impérios que se constituíam no período. Ao mesmo tempo em que, em grande parte das regiões, permaneceu um modo de produção baseado no parentesco ou na linhagem, no qual o trabalho se dava no âmbito familiar e a escravidão quase não tinha importância estrutural, foram se desenvolvendo outras formações sociais que acabaram, dependendo da região, se sobrepondo às demais.

No caso dos reinos ou impérios de Gana, Mali e Songai, notamos o desenvolvimento de um modelo de sustentação econômica baseado, sobretudo, na tributação do comércio de longa distância e no 
controle das principais rotas nas quais esse comércio se desenvolvia. Ao mesmo tempo, desenvolveu-se a produção (ou extração) de mercadorias em grande escala, visando principalmente, quando não exclusivamente, à exportação. Era o caso do ouro, do sal, do cobre, da noz-de-cola e de outros produtos muito apreciados e de alto valor no mercado externo. Junto a isso, os escravos passaram, muitas vezes, a fazer parte da produção (o caso das minas é notável nesse sentido), além de acabarem se tornando essenciais também nas funções domésticas, administrativas e militares.

Ou seja, parece ser possível notar o desenvolvimento, aos poucos, no Sudão Ocidental, de um verdadeiro modo de produção escravista, o qual, entretanto, coexiste com outros modos de produção, nunca exercendo um papel preponderante na sociedade (algo que ocorrerá, sobretudo, nas Américas durante, no mínimo, quase quatro séculos, e na África invadida pelo imperialismo europeu, nos séculos XIX e XX). Quer dizer, os escravos estavam lá, exerciam funções importantes na sociedade e na economia, mas coexistiam, como participantes da produção, com outros tipos de pessoas que trabalhavam sem ser cativas: sejam as linhagens das pequenas aldeias, sejam as castas de ofício das grandes cidades. Entretanto, a partir da queda do Songai, os escravos acabaram se tornando o principal produto de exportação da África subsaariana (algo que, aliás, já estava aos poucos ocorrendo, na medida em que os impérios sudaneses se desenvolviam), fato que teria implicações bastante sérias e desastrosas para as populações africanas negras, sobretudo nos séculos posteriores.

\section{Referências}

CISSOKO, Sékéné Mody. Os songhai do século XII ao XVI. In: Djibril Tamsir NIANI (Dir.). História geral da África. São Paulo: Ed. Ática, 1978. Vol. IV: A África do século XII ao século XVI.

COSTA E SILVA, Alberto da. A enxada e a lança: a África antes dos portugueses. Rio de Janeiro: Ed. Nova Fronteira, 1996. 
COSTA E SILVA, Alberto da. A manilha e o libambo: a África e a escravidão, de 1500 a 1700. Rio de Janeiro: Ed. Nova Fronteira, 2002.

DAVIDSON, Basil. Revelando a Velha Africa. Lisboa: Ed. Prelo, 1977.

HEERS, Jacques. Escravos e domésticos na Idade Média no mundo mediterrâneo. São Paulo: DIFEL, 1983. . História Medieval. São Paulo: Ed. Difel. 1977.

IBN BATTUTA. A través del Islam. Madrid: Alianza, 1987.

KI-ZERBO, Joseph. História da África Negra. Lisboa: Ed. Biblioteca Universitária, 1972. Volume 1.

LOVEJOY, Paul E. A escravidão na África: uma história de suas transformações. Rio de Janeiro: Ed. Civilização Brasileira, 2002.

LY-TALL, Madina. O declínio do Império do Mali. In: Djibril Tamsir NIANI (Dir.). História geral da África. São Paulo: Ed. Ática, 1978. Vol. IV: A África do século XII ao século XVI.

NIANE, Djibril Tamsir. O Mali e a segunda expansão manden. In: (Dir.). História Geral da África. São Paulo: Ed. Ática, 1978. Vol. IV: A África do século XII ao século XVI.

VAN DEN BERGHE, Pierre. O papel das forças armadas na África contemporânea. Afro-Ásia (UFBA), no 2-3, 1966, pp. 111-119 (Disponível online: http://www.afroasia.ufba.br). 


\title{
7 \\ VIAJANTES BRANCOS \\ NA ÁFRICA NEGRA DO SÉCULO XV
}

\author{
Eder da Silveira \\ Silvio Marcus de Souza Correa
}

A tomada de Ceuta em 1415 e o início das viagens atlânticas sob o patrocínio da Coroa portuguesa não são frutos de mero acaso e nem mesmo explicáveis por questões prosaicas, como a proximidade do norte africano e suas ilhas atlânticas com relação a Portugal. Cabe lembrar que, na antigüidade, a Lusitânia e o norte africano estiveram sob domínio do Império Romano. Durante a Idade Média européia, a relação entre ibéricos e magrebinos assumiu novos contornos com a presença moura na Península Ibérica. O prolongado convívio dos peninsulares cristãos com os mouros favoreceu, além das trocas mercantis, um conhecimento indireto sobre o interior da África, sobre suas gentes e, principalmente, sobre uma terra aurífera para além do deserto. Com base no estudo de Jean Devisse (1972), pode-se supor que o comércio entre a África Ocidental e o Mediterrâneo durante a Baixa Idade Média favoreceu a acumulação de um conhecimento empírico por parte dos europeus sobre a hinterlândia africana e, principalmente, sobre o ouro sudanês.

Às vésperas da expansão portuguesa pela costa ocidental da África, a Coroa lusa estava, pois, ciente da importância da posição estratégica de Ceuta, onde um entreposto seria promissor. Como sublinhou Charles Boxer (2002, p. 35), aquele era "um dos portos terminais do comércio transaariano do ouro". A sua conquista significava a abertura do caminho ao tão desejado ouro sudanês. Porém, a presença portuguesa no norte marroquino bastou para Ceuta deixar de ser um ponto de destino das cáfilas (Costa e Silva, 2002, p. 151). 
Com os pés na África, os portugueses começaram a molhá-los no Atlântico e a secá-los nas ilhas Canárias e dos Açores. Logo, já estavam em terra firme, passando o Cabo Bojador e alcançaram a Guiné antes de chegar à metade do século XV. Desde então, o ouro africano passou a chegar a Lisboa devido ao trato direto na costa da Guiné (Braudel, 1990, p. 144). Apesar da presença portuguesa cada vez mais regular na costa africana durante a segunda metade do século XV, o metal amarelo continuou chegando ao Mediterrâneo através das rotas do Saara. Alberto da Costa e Silva (2002, p. 215) concorda que o comércio atlântico provocou mudanças na economia africana e também nas relações política e militar entre grupos praieiros e aqueles do interior da Guiné, porém as caravanas não perderam a sua importância mercantil para os africanos com a chegada das caravelas. Mas as relações luso-africanas não se reduzem ao comércio. Além do interesse pelo ouro e por outras riquezas, demais interesses foram apontados pelos cronistas dos séculos XV e XVI, como Rui de Pina, Gomes Eanes de Zurara, Duarte Pacheco Pereira e João de Barros. Estes mencionam os diversos motivos dos portugueses em seu périplo africano. Assim, a formação de um império, as alianças com grupos africanos e a tentativa de cristianização de populações costeiras foram práticas dos portugueses e de outros europeus a serviço ou com a licença do Infante D. Henrique, durante as primeiras expedições lusas à África.

Em sua Crônica do Descobrimento e da Conquista da Guiné, o cronista Gomes Eanes de Zurara afirmou que as primeiras viagens portuguesas de reconhecimento da costa ocidental africana tiveram como objetivos a) explorar as terras ao sul das Ilhas Canárias; b) estabelecer laços de comércio com seus habitantes; c) informar-se sobre a expansão e a influência muçulmana no interior do continente; d) procurar populações cristãs prontas para auxiliar na luta contra os infiéis; e) expandir o cristianismo. O historiador Charles Boxer (2002, p. 34) chamou a atenção para a constelação de fatores da expansão, composta (a) pelo espírito de cruzada; (b) pela sanha do 
ouro; (c) pela busca de um reino mítico do Preste João; e (d) pela procura de especiarias.

Há, no entanto, uma corrente historiográfica que privilegia os fatores econômicos da expansão marítima. A abordagem macrohistórica do tema prima, em geral, pela formação econômica do mercantilismo na Europa, para a qual a expansão ultramarina e o tráfico negreiro seriam desdobramentos necessários ao desenvolvimento do capitalismo comercial. Essa abordagem macrohistórica perde de vista as motivações e as impressões mais "miúdas".

Para o estudo da História, os modelos teóricos, seus conceitos e seu esquema interpretativo são, muitas vezes, de difícil compreensão para o público leigo ou mesmo para os estudantes de História. Não raro, as interpretações macrohistóricas incorrem em esquemas artificiais que acabam por tolher qualquer compreensão de realidades pretéritas.

Sem abandonar um referencial teórico e um rigor metodológico que prescindem à interpretação e à própria escrita da História, acreditamos que a análise dos relatos de viagem pode auxiliar a conectar interesses e motivações individuais e aquilo que era parte de um projeto maior de grupos mercantis e das realezas européias. A literatura de viagem oferece à pesquisa histórica uma valiosa fonte documental. Destaca-se nessa literatura a descrição das viagens à África negra (1455-1456), do veneziano Alvise Cadamosto, e da viagem à costa da Guiné e à Península Ibérica (1479-1481), do flamengo Eustache Delafosse. Ambos os relatos se inscrevem numa narrativa moderna sobre a costa ocidental africana e suas gentes.

Se, de modo geral, as crônicas reais de Gomes Eanes Zurara, Rui de Pina, João de Barros e outros dão maior atenção aos feitos da lusitanidade, os relatos de Cadamosto e Delafosse nos oferecem elementos mais "miúdos" das navegações. Esses relatos não revestem as ações dos europeus na África de uma missão evangélica ou salvacionista. Nos relatos do veneziano e do flamengo, os portugueses não aparecem como um povo predestinado, como os cro- 
nistas portugueses e mesmo alguns poetas e historiadores modernos declararam ou insinuaram. Como exemplo, poderíamos lembrar alguns versos de Fernando Pessoa (1996, p. 55), para quem as ações individuais representavam uma vontade coletiva, ao mesmo tempo popular e monárquica:

Aqui ao leme sou mais do que eu: Sou um povo que quere o mar que é teu; $\mathrm{E}$ mais que o mostrengo, que me a alma teme E roda nas trevas do fim mundo, Manda a vontade, que me ata ao leme, De El-Rei D. João Segundo!

O poeta ainda considerou válido todo o esforço humano para um povo predestinado; afinal, para cruzar o mar, "quantas mães choraram, quantos filhos em vão rezaram! Quantas noivas ficaram por casar para que fosses nosso, ó mar!’”. O ufanismo na literatura e em toda uma historiografia portuguesa tradicional minimiza ou mesmo anula as motivações individuais, as ações e as interações humanas cujos efeitos inusitados demonstram o quanto qualquer processo histórico deve à contingência.

Os relatos de Cadamosto e Delafosse se afastam de qualquer mística ou predestinação e realçam de forma particular as dimensões mais ordinárias e mais subjetivas da aventura de lançar-se ao mar. Além disso, os relatos de viagens nos oferecem certas conexões entre outras histórias que escapam aos esquemas macroestruturais de quase toda "história geral" ou teleológica. Escusado lembrar que muitos relatos de viajantes serviram como fonte para cronistas e historiadores. Além disso, alguns deles foram como etnógrafos avant la lettre na interpretação e na representação da alteridade e da diversidade cultural na África negra.

\section{O Conhecimento sobre a África Negra na Europa Ocidental}

Durante a Idade Média, as referências literárias ao negro baseavam-se quase exclusivamente na tradição bíblica e em alguns 
textos da Antigüidade greco-romana. José Rivair Macedo (2001) apresentou uma síntese do saber enciclopédico medieval na Península Ibérica sobre os africanos como "filhos de Cam". Porém, a iconografia ibérica e flamenga dos séculos XV e XVI aponta para um conhecimento mais "realista" que advém do comércio atlântico. No acervo do Museu do Prado, em Madri, vários quadros representam figuras negras. Entre elas, destacam-se as pinturas Adoração dos reis magos, de Hans Memling (c.1453-1494) e de Jerônimo Bosch (c.1450-1516). Deste último, ainda há o famoso tríptico O jardim das delícias, em cujo painel central há várias figuras negras. No painel da esquerda, animais africanos, como elefante, girafa e porco-espinho, estão representados.

Sobre os africanos que serviram de modelo aos pintores, gravuristas e desenhistas europeus da Renascença, pouco se sabe. De Albert Dürer há um desenho que retrata um negro (1508) e outro uma negra "moura” de nome Catarina (1521). Esta última era doméstica do português João Brandão (Eichler, 1999, p. 114).

Além das informações que eram obtidas dos africanos levados para a Europa, o comércio mediterrânico com o norte da África permitiu que os europeus obtivessem informações indiretas sobre as populações do interior da África.

Desde a tomada de Ceuta em 1415 até o final do périplo africano em 1498, os portugueses acumularam várias experiências (mercantil, militar, diplomática, cultural) na África. Após a passagem do Cabo Bojador em 1434, os portugueses alcançaram a Guiné e o Cabo Verde uma década depois. Chegaram à Costa da Malagueta em 1470. Dali, eles fincaram pé em área vizinha, onde construíram a fortaleza d'El Mina em 1482. Na mesma década, Diogo Cão explorou a embocadura do Rio Zaire, e Bartolomeu Dias alcançou a estremadura austral da África. Em 1497, Vasco da Gama ainda fincou padrões na costa africana antes de chegar à Índia e tratou com africanos da costa índica, embora nem sempre de maneira amistosa. 


\section{A Presença Portuguesa na Costa Africana no Século XV}

Dessa experiência luso-africana do século XV, há uma copiosa documentação. Dela se destaca a Monumenta Henricina, coleção organizada por Dias Dinis (1960) e obra imprescindível para os estudos dos primórdios das relações luso-africanas. Coleção mais recente é Portugalie Monumenta Africana, a qual reúne, em dois volumes, 480 documentos relativos às atividades portuguesas na África desde 1443 até 1499. A natureza desse material é variada: bulas papais, tratados, cartas de mercês, cartas de doação ou de privilégios, cartas de procuração, registros notariais e alvarás.

Escrita em 1448, a Crônica do Descobrimento e da Conquista da Guiné, de Gomes Eanes de Zurara, contém importantes informações sobre os primeiros contatos dos europeus com os habitantes das Canárias, com os mouros do Saara e com os negros da chamada Guiné. Deprima inventione Guinee, do português Diogo Gomes, também faz parte deste inventário documental, com informações valiosas sobre os reinos mandingas. Outro documento importante para o século XV é o já mencionado relato das viagens (1455-56) do veneziano Alvise Cadamosto, publicado pela primeira vez em 1507. Outras fontes alusivas à Guiné são os livros Esmeraldo de Situ Orbis, de Duarte Pacheco Pereira; Descrição da costa ocidental da Africa, de Valentim Fernandes, e Décadas, de João de Barros. Outras referências dignas de nota sobre a Guiné são: os relatos das navegações do português Pedro de Sintra (1460) e do comerciante flamengo Eustache Delafosse (1479-1481). Já a Relação do Reino do Congo, de Rui de Pina, se constitui fonte importante para os estudos das relações luso-africanas no Congo no último quartel do século XV.

\section{Viajantes Brancos na África Negra}

Apesar da copiosa documentação portuguesa sobre a África atlântica, o relato de Cadamosto tem uma particularidade inigualável. 
No que concerne à alteridade africana, esta foi percebida de forma original pelo veneziano. Sua visão é fundamentalmente moderna. Ela difere da imagem medieval e tampouco se orienta pela tradição bíblica ou pelos clássicos antigos como Heródoto, Ptolomeu e Plínio. As fantasias e as imagens mitológicas, presentes nas cartografias e nas descrições clássicas e medievais, já não aparecem no seu relato de viagem (Correa, 2002, p. 111).

Posto a serviço do Infante Dom Henrique, Cadamosto foi um dos vários italianos a se aventurar pelo Atlântico. As suas duas viagens (1455-1456) à África negra se integram à fase pioneira dos "descobrimentos portugueses". A partir de sua experiência africana, Cadamosto deu informações importantes sobre o potencial econômico da chamada Guiné, sobre a influência muçulmana na África negra e sobre as possibilidades de uma expansão do cristianismo naquela região. O relato de suas viagens revela também certos interesses pessoais do veneziano, bem como da Coroa portuguesa. Além disso, informa sobre certos grupos africanos, alguns interessados, outros não, em manter contato com os europeus.

No relato do veneziano sobre a Guiné, escravos já são mencionados. O próprio Cadamosto, inicialmente mais interessado em negociar seus cavalos por ouro, ao invés do metal amarelo, obteve como pagamento pelos animais africanos escravizados. Diogo Gomes, Valentim Fernandes e Duarte Pacheco Pereira também mencionam a escravidão africana e a certa facilidade dos portugueses em obter escravos. Mas na segunda metade do século XV, a demanda européia por escravos africanos é ainda pequena quando comparada à dimensão que ela adquire a partir da colonização do Novo Mundo.

Desde o início do contato com as gentes da Guiné, os europeus já enfrentavam hostilidades e certas dificuldades em mercadejar em algumas partes da costa. Em 1446, o português Nuno Tristão e sua tripulação foram atacados num dos rios da Senegâmbia, onde as flechas ervadas dos africanos causaram várias baixas entre os portugueses. Quase dez anos depois, o genovês Usodinare e o veneziano Ca- 
damosto tiveram dificuldades em mercadejar por aquela costa. Já o português Diogo Gomes conseguiu adentrar aquela região e tratar com os mandingas. Depois dele, os portugueses passaram a freqüentar anualmente o Rio Gâmbia, o Casamansa, o São Domingos (ou Cacheu) e o Rio Grande (Niane, 1989, p. 31).

Vários historiadores (Niane, 1989, p. 28; Braudel, 1990, p. 137; Costa e Silva, 2002, p. 204) atentaram para a concomitância da presença cada vez mais regular dos portugueses na costa da Guiné com o declínio do Império do Mali e a ascensão do Império Songai. Mas isso não significa uma correlação direta entre o dinamismo econômico nas províncias ocidentais dos mandingas a partir da segunda metade do século XV e a presença européia na costa atlântica.

Quando morre o Infante Dom Henrique (1460), os portugueses já mantêm uma presença constante na Guiné. Para manter o comércio ultramarino e as expedições marítimas em curso, a Coroa portuguesa buscou um consórcio com a empresa privada. Através de um contrato com o burguês lisboeta Fernão Gomes (1468-1474), o rei D. Afonso V lhe concedeu o monopólio comercial da Guiné.

Tal monopólio não foi respeitado pelos castelhanos que visavam fazer trato e resgate na Guiné. Duarte Pacheco Pereira nos informa sobre o naufrágio na Costa da Malagueta de um navio flamengo sob comando castelhano e sobre o infortúnio de seus tripulantes. O consórcio espanhol e flamengo não parou por aí, pois outro navio foi capturado pelos portugueses e sua tripulação levada para Lisboa para ser enforcada por crime de contrabando. Entre os prisioneiros, estava o comerciante flamengo Eustache Delafosse, cujo relato é rico em informações sobre o comércio na costa africana, inclusive de escravos. Cabe lembrar que, assim como Cadamosto, Delafosse comprou e vendeu escravos africanos.

Enquanto os portugueses, espanhóis e flamengos concorriam na costa da Guiné, relações conflituosas entre as coroas ibéricas ga- 
nhavam novos contornos no campo diplomático, no qual um tratado luso-castelhano foi firmado em setembro de 1479, sendo ratificado pelos reis católicos em março de 1480.

Após o êxito comercial de Fernão Gomes, do tratado luso-castelhano de Alcaçovas (1479) e da bula papal aterni regis (1481), em que o Papa Xisto IV ratificou as cláusulas da partilha das zonas de influência das coroas ibéricas, a Coroa portuguesa resolveu instalar um forte na costa africana. Diogo Azambuja escolheu o local em 1482 e negociou com líderes locais a aquiescência para tal fundação. O famoso forte São Jorge de Mina foi construído em poucas semanas e, a partir de então, os portugueses tentaram obter maiores vantagens comerciais, além de consolidar suas alianças com grupos africanos e, na medida do possível, convertê-los ao cristianismo. Porém, a situação não era das mais favoráveis para a instalação permanente de portugueses naquelas bandas. Além de alguns mal-entendidos, os portugueses desconheciam muitas regras sociais, culturais e religiosas das comunidades locais. A presença permanente de portugueses logo teria um custo elevado, e poderíamos dizer que os portugueses não premeditaram alguns embaraços naquela costa, onde os reinos faziam muitas exigências para tolerar estrangeiros na periferia de suas áreas de influência.

A minuciosa pesquisa do historiador africano Ballong (1993) demonstra como os portugueses "se africanizaram" na Costa da Mina, onde as trocas comerciais, nas quais os portugueses eram às vezes meros intermediários, as alianças e o modus vivendi acusam a predominância cultural africana. No entanto, os portugueses também foram hábeis em suas alianças comerciais e político-militares com os reinos vizinhos, especialmente de Eguafo e Fetu.

Além da aliança com certos grupos da Costa da Mina, os portugueses ainda selaram alianças importantes com os ntotila do Congo a partir de 1482. A cristianização do manicongo teve desdobramentos importantes para as relações luso-congolesas e, assim como na Costa da Mina, os portugueses lograram fazer parte da complexa rede comercial da costa africana. Muitas mercadorias européias eram introduzidas 
no comércio africano por mãos portuguesas, mas muitas mercadorias africanas eram trocadas nos mercados africanos por essas mesmas mãos.

Em outras palavras, os portugueses serviram também de intermediários do comércio africano e acabaram por ampliá-lo em termos inter-regionais pela via marítima. No último quartel do século $\mathrm{XV}$, os portugueses navegavam por toda a costa atlântica da África. Em muitas regiões costeiras, o comércio com os portugueses alterou a organização social e econômica e também as relações políticas, militares e comerciais entre reinos praieiros e destes com aqueles do interior.

Valetim Fernandes (1951, p. 61-64), por exemplo, foi um dos que mencionou a influência portuguesa na rede comercial dos mandingas. Os portugueses chegaram a fundar uma vila no interior da Gâmbia, onde eles prometeram ajudar militarmente seus aliados mandingas. A propósito, João de Barros nos informa que o caramansa chegou a pedir ajuda militar a D. João II diante da ofensiva fula em 1490. O rei português enviou uma embaixada ao seu aliado, mas nada de auxílio militar. Em 1535, houve mais um apelo mandinga aos portugueses e, novamente, a ajuda militar não veio. Outros aliados africanos também ficaram sem receber o apoio prometido ou suas demandas não foram atendidas pelos portugueses. As cartas do manicongo D. Afonso, expedidas entre 1512 e 1540, acusam o impasse, a omissão, o paradoxo e a dubiedade da Coroa portuguesa com seus aliados congos.

\section{Considerações Finais}

O poeta e historiador Alberto da Costa e Silva escreveu com toda propriedade e no melhor estilo sobre as possíveis impressões de estranhamento que os africanos da costa tiveram ao ver chegar os forasteiros, de pequena estatura, com seus cabelos lisos e longos, suas faces rosadas e barbudas, o nariz comprido, os lábios estreitos e uma pele muito desbotada. Aquela gente branca parecia não ter artelhos e cheirava muito mal. Alguns deles, vítimas do escorbuto, tinham uma 
boca desdentada e sangrenta. Não raro, eram os que tinham uma pele sarnenta, que desciam à praia num péssimo aspecto, adoentados, com febres ou infestados de pulgas e piolhos.

Essa gente era, contudo, obstinada e muito curiosa. Fazia muitas perguntas sobre a região, suas riquezas, seus régulos, suas gentes, sua religião. Apesar de mostrarem grande fragilidade física às doenças tropicais, aqueles homens tinham armas mortíferas que cuspiam fogo e faziam grande estrondo como trovão. Traziam muitas mercadorias que interessavam os africanos, outras nem tanto. Tinham enormes embarcações e singravam os mares com rapidez, alcançando terras e ilhas inatingíveis à navegação de cabotagem dos africanos.

Durante todo o século XV, esses forasteiros foram se fazendo cada vez mais presentes na costa africana do Atlântico, selaram alianças com alguns africanos e entraram em contendas com outros. Tiveram filhos mestiços, enriqueceram alguns comerciantes, régulos e reis e empobreceram outros, incrementaram o comércio local com novas mercadorias, mas tiraram da terra muitos de seus filhos através da compra e venda de escravos. Profanaram locais sagrados, queimaram ídolos e trouxeram uma nova religião. Interferiram também na paisagem litorânea da África, onde introduziram animais e vegetais vindos da Europa ou da Ásia, estabeleceram padrões, ergueram cruzes, construíram capelas, feitorias e fortalezas.

Ao final do século XV, as relações luso-africanas haviam se intensificado na costa atlântica. Essa experiência africana marcaria indelevelmente as relações luso-indianas e luso-brasileiras das primeiras décadas dos Quinhentos. Aliás, não é de se estranhar que, na segunda viagem para a Índia, o capitão-mor Pedro Álvares Cabral mandou descer um batel à praia de uma terra recém-avistada, onde o primeiro contato se deu como na África. Afinal, um negro grumete se dirigiu em língua da Guiné àquela gente "de cor baça e de cabelo comprido e corredio, e a figura do rosto coisa mui nova" (Barros, 1982, p. 107-108). Se levarmos em conta o triste fim do turgimão negro da tripulação do genovês Antoniotto Usodinare ao descer num rio da 
Senegâmbia em 1455, podemos supor que o grumete sabia o risco que corria ao abrir a boca em outras praias. Diante da incompreensão daquela língua africana, tentaram alguns marinheiros ainda se comunicar em árabe. Sem saber nenhuma língua africana e tampouco o árabe, aquela gente praieira pareceu, aos portugueses, mais próxima àquela encontrada pelos castelhanos em suas viagens ao Poente. Deduziram que haviam chegado a outra margem do Atlântico, após quase um século de experiência na costa africana.

\section{Referências}

BALLONG, J. Bato’ora. São Jorge da Mina. 1482-1637. Lisboa: Fundação Calouste Gulbenkian, 1993.

BARROS, João de. Décadas (Selecção, Prefácio e Notas de António Baião). Lisboa: Livraria e Editora Sá da Costa, 1982.

BRAUDEL, Fernand. La Méditerranée et le monde méditerranéen à l'époque de Philippe II., 9 $9^{\text {ème }}$ edition. Paris, 1990.

CADAMOSTO, Alvise. Voyages en Afrique Noire (tradução e notas de Frédérique Verrier). Paris: Editions Chandeigne/Unesco, 1994. 


\section{OS ESTADOS AFRICANOS \\ NOS SÉCULOS XVI-XVIII: DESENVOLVIMENTO DESIGUAL NA ÁFRICA OCIDENTAL}

\section{André Luiz Reis da Silva}

Quando os portugueses conquistaram Ceuta (1415) e deram início ao périplo africano, no contexto do mercantilismo, da formação dos Estados nacionais europeus e da constituição de um sistema mundial capitalista, os Estados africanos viviam seu próprio desenvolvimento. Ao observar-se o mosaico de organizações políticas que amalgamavam uma plêiade de formações econômicas e sociais, verifica-se que o continente detinha uma grande complexidade de relações e estava em pleno desenvolvimento.

O continente vivia uma história, estava em movimento e não congelado no tempo. Também não era um paraíso perdido na História, posteriormente subjugado pelas maquinações européias, em uma visão que desumanizaria o africano, pois não lhe atribui as contradições existentes em qualquer sociedade. O continente passava por suas próprias transformações, baseadas também na arrecadação de tributos, no trabalho compulsório, bem como nas lutas pelo poder e pelo controle das riquezas ou das rotas de comércio, tal e qual os europeus na formação de seus Estados nacionais.

E é precisamente essa dinâmica própria que se rearticulará no contato com os europeus, promovendo desestruturações/reestruturações. Nesse sentido, este texto tem como objetivo analisar as conseqüências para o continente africano, em especial a África Ocidental, do contato com os europeus ao longo dos séculos XVI-XVIII. Parto da problemática do desenvolvimento desigual e combinado, para 
poder perceber como a combinação e a articulação das formações européias e africanas provocaram as transformações no continente, sobretudo o bloqueamento das formações tributárias e sua dependência ao capitalismo nascente.

\section{O Desenvolvimento Desigual}

\section{e Combinado nas Formações Pré-capitalistas Africanas}

De acordo com Samir Amin (1976), Modo de Produção é um conceito abstrato, não implicando em uma lógica rígida de sucessão entre eles e nem existindo de forma "pura" em alguma sociedade, conforme trabalhado pela historiografia tradicional. De acordo com Amin, podese distinguir cinco modos de produção: 1) modo de produção "comunitário primitivo" anterior a todos os outros; 2) modo de produção tributário; 3) modo de produção escravista; 4) modo de produção "mercantil simples", e 5) modo de produção capitalista. Mas nenhum desses modos de produção existiu na forma ideal, pois as sociedades históricas são formações que combinam modos de produção variados. Segundo Amin, "as formações sociais são, portanto, estruturas concretas, organizadas, caracterizadas por um modo de produção dominante e pela articulação à volta deste de um conjunto complexo de modos de produção que a ele estão submetidos" (Amin, 1976, p. 12). Assim, é possível ver a articulação de diferentes formas de produção em uma sociedade concreta, e convém identificar, então, qual é o modo dominante e qual é o ascendente.

Conforme Samir Amin, todas as sociedades pré-capitalistas são formações sociais combinando os mesmos elementos: 1) dominância do modo de produção comunitário ou tributário; 2) existência de relações mercantis simples com um âmbito limitado, 3) existência de relações de comércio de longa distância, que articula diversas formações autônomas e permite a transferência do excedente de uma sociedade para outra. Uma formação social que depende basicamente do comér- 
cio de longa distância marca que ela tem baixa produção de excedente interno, e essa formação pode entrar em ascensão ou decadência de acordo com as trocas comerciais, não importando diretamente se teve uma modificação notável na produção de seu excedente.

Quando da chegada dos europeus à África, o continente encontrava diversas formações sociais, tendo o predomínio das variações de modo de produção comunitário e tributário. Sobre os modos de produção comunitário, de acordo com Samir Amin,

a África negra apresenta uma gama variada destes modos de produção, uns relativamente pouco hierarquizados - nomeadamente no território banto -, outros fortemente desiguais como entre os tucolores no Vale do Senegal, os achânti do Gana, os hauçás do norte da Nigéria, etc. Mas sempre o camponês tem acesso à terra; por pertencer a um clã, tem direito a uma parcela do território deste. Daí, que seja impossível o processo de proletarização, isto é, de separação do produtor de seus meios de produção. (Amin, 1976, p. 10)

Nas civilizações pré-capitalistas, as formações sociais mais comuns são aquelas que apresentam como modo de produção dominante o tributário. As formações tributárias se dividem em três grandes categorias: 1) formações tributárias ricas, fundadas num excedente interno volumoso, como Egito e China; 2) formações tributárias pobres, caracterizadas pelo pequeno volume de excedente, como sociedades medievais e o feudalismo, e 3) formações tributárias comerciantes, dependentes das rotas de comércio, como a Grécia Antiga, o mundo árabe no seu apogeu e diversos Estados da savana africana (Amin, 1976, p. 15). O escravismo aparecia marginalmente (África) ou com centralidade (Grécia Antiga) nessas formações tributárias comerciantes.

Tanto as formações africanas com centralidade comunitária como as formações com centralidade tributário-mercantil foram fortemente impactadas com o contato e o comércio com os europeus. Entretanto, se o impacto gerou o capitalismo na Europa (que veio justamente da sua pobreza relativa), na África ocorreu o bloqueamento, precisamente porque faltou um dos elementos essenciais para a emergência do capitalismo: a desestruturação das relações feudais. $\mathrm{O}$ outro elemento (acumulação de capital) pode ser encontrado em al- 
gumas sociedades do norte da África, que marcou o apogeu de grandes impérios africanos, mas tinham pouco excedente, e esse lucro vinha mais do comércio de longa distância do que a articulação com a produção local. Ou seja, essas formações eram fundadas não sobre o excedente tributado aos camponeses na região, mas sobre os lucros do grande comércio. De acordo com Samir Amin,

é assim que todos os grandes Estados magrebinos foram estabelecidos sobre o comércio do ouro proveniente da África do Oeste. Durante séculos, até a descoberta da América, a África do Oeste será o principal fornecedor do metal amarelo para toda a parte ocidental do mundo antigo (Amin, 1976, p. 35).

Os períodos brilhantes da civilização árabe no norte da África não são caracterizados por grandes realizações agrícolas, mas pela prosperidade do comércio e das cidades. A decadência virá com o desvio das rotas comerciais.

É exatamente nesse ponto que preconceitos ideológicos desfavoráveis à África costumam aflorar. As formações africanas pré-mercantilistas são autônomas, e seu desenvolvimento ocorre de forma paralela e articulada com as formações da Ásia, do Mediterrâneo (sul da Europa) e do Oriente Médio. A África fazia a articulação entre essas três regiões e estava integrada na História mundial quando chegaram os portugueses, no século XV. As estruturas africanas se equiparavam em desenvolvimento às suas análogas em diversas outras regiões, e os relatos dos viajantes admirados com as "maravilhas" dos Estados africanos corroboram essa tese.

Mas o comércio mercantilista, nos séculos XVI-XVIII, foi mais além do que o "comércio igualitário" da fase anterior, pois engendrou o sistema capitalista e desagregou as relações feudais (na Europa) e tributárias e comunitárias (essencialmente na África). A força resultante foi a formação do sistema capitalista a partir do mercantilismo, com uma especialização e divisão internacional do trabalho, no qual os reinos africanos ficariam incumbidos basicamente de fornecer mãode-obra escrava, além de poucos produtos extrativistas. Assim, esses Estados africanos no início do século XVI são embriões de nação des- 
truídos pelo fim do comércio saariano e pela rearticulação atlântica. O Império Songai constituiu um exemplo claro dessa situação. O último grande Estado mercantil-tributário do Sudão Ocidental vivia um momento de transformação interna rumo, talvez, a uma especialização e organização com corte classista. Mas a invasão da região pelos mercenários do sultão de Marrocos e a derrota do Estado Songai em 1591 puseram fim ao império e interromperam esse processo. Com a chegada dos europeus e o estabelecimento de comércio no litoral, as linhas comerciais que passavam pelos domínios de Songai foram se enfraquecendo, e o império ruiu.

O deslocamento do centro de gravidade do comércio africano (da savana para a costa) reflete, em certa medida, o deslocamento do centro de gravidade do desenvolvimento europeu (do Mediterrâneo para o Atlântico), no qual as relações África-Europa estariam submetidas agora ao quadro mais amplo de formação do capitalismo mercantilista, que desenvolveu desigualmente as formações sociais que engendrava. Conforme Samir Amin,

é evidentemente impossível saber o que se tornariam as formações africanas se tivessem continuado a evoluir por si mesmo depois do século XVII. Integradas num estádio precoce no sistema capitalista nascente, o estádio mercantilista, foram, na realidade, destruídas nesta época e não tardarão a regredir. Pode-se calcular-se, contudo, que o grande comércio africano prémercantilista, brilhante em certas regiões, mas articulando-se em formações comunitárias ou tributárias relativamente pobres, não teria podido gerar por si só o modo de produção capitalista (Amin, 1976, p. 41).

\section{A Chegada dos Europeus}

\section{e a Rearticulação Econômica no Norte da África}

De fato, a chegada dos europeus ao continente africano no século XV, a partir do périplo português, foi um dos acontecimentos de maior impacto no continente, cujas conseqüências se fazem sentir até nossos dias. Em síntese, significou o bloqueamento do desenvolvimento próprio do continente africano e sua rearticula- 
ção em direção ao desenvolvimento do capitalismo, cujo epicentro seria agora o Atlântico.

Inicialmente, a África não interessava diretamente aos portugueses, os quais percebiam o continente como um ponto de escala na rota para a Ásia. Os portugueses não tinham como objetivo direto colonizar a África, mas assegurar-se de bases comerciais e pontos de apoio, por isso o interesse em se apoderar das ilhas e dos locais litorâneos. Mesmo com o comércio de escravos e a implantação de feitorias, os portugueses não se aventurarão muito além da costa africana (Berteaux, 1974, p. 116-117). Os franceses foram uma exceção e penetraram o Rio Senegal em meados do século XVII (Berteaux, 1974, p. 140).

Mas os lançados, ou tangomaus, tiveram uma importância estratégica no estabelecimento das redes comerciais entre os europeus e africanos. Esses homens, na maioria degredados ("lançados" às praias) ou aventureiros, eram deixados nas costas da África, Ásia e América. Os poucos que sobreviviam às doenças e aos ataques conseguiam adquirir alguma imunização e conhecimento do terreno por onde andavam. Esses homens aprendiam as línguas dos africanos, seus métodos de comércio e se tornaram responsáveis pela atividade comercial. Nesse aspecto, convém recordar que Cabo Verde, a qual começou a ser povoada em 1462, com portugueses e escravos africanos, também foi em grande parte responsável pelo comércio com o continente. A atuação dos mulatos miscigenados chegou, inclusive, a gerar preocupação por parte da Coroa portuguesa, a qual procurou intensificar o envio de mulheres brancas degredadas para Cabo Verde. Duvidava-se da lealdade dos mulatos, com ligações africanas, para com a Coroa portuguesa em relação ao comércio (Silva, 2002, p. 232-234).

No início do século XVII, outras nacionalidades européias alcançarão a África, sobretudo holandeses e ingleses. Os holandeses procuraram fragilizar as conquistas portuguesas no continente, como El Mina, na Costa do Ouro, em 1637, e Luanda (que ocuparam de 1641-1648). Em 1652, os holandeses fundaram a Cidade do Cabo. A partir de 1533, os ingleses fizeram expedições regulares ao continen- 
te e entraram em diversos conflitos com os portugueses. Em 1626, foi criada a Companhia francesa da África Ocidental, e os franceses se estabeleceram no Senegal. Nesse período, o principal interesse dos europeus na África será o escravo.

Assim, nos séculos XVI e XVII, houve a formação de novas organizações políticas africanas, as quais, em conjunto com outras mais antigas, prosperam em função do comércio de escravo (como os achântis e iorubás, do Daomé) e das armas de fogo obtidas. A fragilidade desses Estados apareceu com o fim do tráfico de escravos, em meados do século XIX, porque temporariamente nenhum outro produto parecia substituir o comércio de escravos (Berteaux, 1974, p. 140).

Com o tráfico de escravos no litoral, o comércio transaariano entrou em processo de estagnação, em contrapartida com a ampliação das correntes comerciais em direção ao litoral atlântico. Conforme Alberto da Costa e Silva, ocorreram mudanças políticas com a instalação de três dezenas de fortes europeus na Costa do Ouro, e os comandantes e feitores europeus tinham de pagar tributos aos régulos das terras onde estavam presentes, mas em outros locais passaram à posição de predomínio e se invertia a prática, começando a cobrar impostos dos chefes africanos da vizinhança. De acordo com Costa e Silva, as fortalezas européias também provocavam outros efeitos:

Muitos africanos, por exemplo, passaram nelas a trabalhar como assalariados e nelas não só adquiriam novos ofícios ou adaptaram os que já tinham ao gosto do branco, como também aprenderam as manhas deste. Outros aprenderam em casa, pois nasceram de uniões entre europeus e mulheres da terra. E alguns aproveitavam esse conhecimento para se tornarem intermediários ágeis e sagazes entre os brancos, de um lado, e os reis, chefes e batanis aças. Não faltou quem fosse além e construísse sua própria estrutura de poder (Silva, 2002, p. 814).

Se, inicialmente, os mais diversos produtos serviam como base de troca pelos escravos (na maior parte consideradas "presentes"), com o passar do tempo e a sistematização do tráfico, os comercian- 
tes africanos passaram a exigir um leque mais restrito de mercadorias. Além das contas (como cauris) utilizadas como moeda, os produtos incluíam tecidos, armas de fogo, facas, pólvora, bebidas alcoólicas, fumo, açúcar, bacias de cobre, basicamente produtos de consumo que em pouco contribuíam para o desenvolvimento econômico africano, cuja drenagem de mão-de-obra já fazia sentir seus efeitos, ainda que compensada pela drenagem menor de mulheres.

\section{Os Novos Estados do Litoral: Fortalecimento e Dependência Durante o Mercantilismo}

O contato com os europeus interferiu e rearticulou diretamente diversas organizações políticas africanas em processo de formação/ aglutinação. A centralização de impérios, as novas organizações econômicas passaram a ter de contar com a variável das relações com os europeus, os quais poderiam se tornar aliados ou inimigos, em um complexo jogo que reunia alianças, federações e sucessão de domínios e hegemonias. O que ressalta nesse processo é a incapacidade européia de domínio imediato do continente africano, bem como a impossibilidade de derrotar/submeter diversos impérios poderosos, que contavam com armamento suficiente, em muitos casos, para repelir as investidas européias ou promover alianças com esses. Assim, diversas organizações políticas africanas foram rearticuladas a partir do contato com os europeus e verificaram um incremento de seu poderio a partir do controle do comércio no litoral, sobretudo de escravos.

Um dos grandes beneficiários do tráfico atlântico de escravos foram os achântis. Desde o século XI e XII, organizaram-se pequenos principados formados por povos akans e que foram enquadrando as tribos autóctones, as quais nesses territórios tinham como base o comércio de noz-de-cola e de ouro. Os fantis vieram mais ao Sul e se estabeleceram próximo ao litoral. As cidades-Estados formadas na 
costa africana procuraram resistir às tentativas de conquista dos impérios do interior e poderiam ser apoiadas pelos fortes europeus.

A rivalidade fanti-achânti foi aproveitada pelos europeus nesse período, no qual os fantis acabavam submetidos (Ki-Zerbo, 1999, p. 345-346). Os achântis vendiam escravos em troca, sobretudo, de armas de fogo, o que servia para ampliar seu território, alcançando extensão máxima na metade do século XVIII. No início do século XIX, o império achânti era poderoso e centralizado, organizado em uma burocracia eficiente. Entretanto, o fim do tráfico atlântico de escravos selaria o destino deste império, que entrou em diversos conflitos com os britânicos, até serem definitivamente incorporados como colônia da Costa do Ouro, em 1901.

Os Estados Mossi (como Tencodogo, Uagadugu, Iatenga, entre outros) foram criados entre os séculos XIV e XV e chegaram a ser vassalos do Império Songai no século XV, mas recuperaram sua autonomia no século XVI. Pelos Estados Mossi não passavam inicialmente as rotas de comércio de ouro e de noz-de-cola, mas circulavam outros produtos. Mas os mossis procuraram estabelecer ligações com as rotas mercantis que passavam perto de seu território, para em seguida controlá-las. Os mossi também preavam e vendiam escravos (Silva, 2002, p. 803). Em 1896, os mossi se tornaram um protetorado francês (atual região de Burkina Fasso).

Quando os portugueses entraram em contato com o antigo Reino do Benim (atual cidade da Nigéria, não confundir com a República de Benin, antes chamado Daomé), por volta de 1480, o reino se encontrava em plena expansão, através de guerras. Segundo descrições dos portugueses, teria umas oitenta léguas de comprimento por quarenta de largura. Nos últimos anos do século XV, uma expedição portuguesa foi à capital do reino para estabelecer os primeiros contatos com Evaré, o Grande, o obá ${ }^{1}$ em exercício (era o décimo-quinto da dinastia). O obá recebeu bem os portugueses. O comércio en-

\footnotetext{
${ }^{1}$ Título atribuído aos governantes do Benim.
} 
tre os portugueses e Benim, além de escravos, envolvia armas, pimenta, vestimentas e marfim.

O obá Esigi (ou Eisigie) que sucedeu Evaré foi ainda mais favorável aos portugueses. Interessado pelas armas de fogo que eles portavam, enviou em 1514 uma embaixada para Portugal. Instruído pelos portugueses que comerciavam em Benin, o obá pediu missionários, pois um decreto papal impedia a venda de armas para pagãos e infiéis (Silva, 2002, p. 314). De acordo com Costa e Silva, os dois representantes do Benin levavam consigo 12 cativos, para irem vendendo conforme as necessidades, além de terem pago com quatro cativos para serem levados a Portugal em um barco. Entretanto, continua o autor:

Os dois dignitários foram esbulhados pelo capitão do barco, que lhes tomou seis cativos, e chegaram a Lisboa com pouco para se sustentarem. Providenciou, porém, a Coroa Portuguesa para que nada lhes faltasse. De modo que regressaram ao Benin de boa saúde e com muitos presentes, acompanhados por missionários, mas sem os arcabuzes e canhões. (Silva, 2002, p. 314)

O obá não se converteu ao catolicismo, mas permitiu a construção de igrejas e que os missionários pregassem no seu reino. Mas sem a conversão do reino (como fez seu contemporâneo manicongo Afonso, rei do Congo), o Rei de Portugal, D. João III, não autorizava a venda de armas, o que provocou a diminuição do interesse do Benim pelo comércio com Portugal. O obá respondeu ao embargo de armas abrindo e fechando mercados no comércio com os portugueses e controlando a venda de escravos, chegando até a interditar por um tempo a venda de escravos homens para os portugueses. Mas o obá acabou conseguindo as armas, através do comércio com outras nações européias (Silva, 2002, p. 317).

A noroeste do Benim encontrava-se o reino fon de Daomé (na atualidade, corresponde ao Benim), que incluía os reinos Alada, Ajudá e Popó. Esses reinos se ligaram a atividades de comércio de escravos e estavam submetidos à influência do reino de Oió. A capital do Daomé (grande Alada) possuía cerca de $25 \mathrm{~km}$ de circunferência e cerca de 30 
mil habitantes. A fuga ao assédio europeu provocou a instalação do reino de Daomé em Abomé, que no século XVIII vem a ser a maior potência da região (Del Priore; Venâncio, 2004, p. 121).

No século XVIII, o reino de Daomé se expandiu e seu chefe, Agaja, comerciava com portugueses e brasileiros, que lhe pagavam em ouro pelos escravos. Embora também cultivasse plantações de mandioca, milho, tomate e tabaco, entre outras, a principal atividade econômica do reino era a exportação de escravos e óleo de palma (Del Priore; Venâncio, 2004, p. 122). O reino de Daomé durou até o século XIX, quando foi dominado por tropas senegalesas da França e incorporado às colônias francesas da África Ocidental.

Os iorubas estabeleceram, no século XVII, o reino de Oió, um Estado forte entre o Daomé e o Rio Níger. Esse reino organizava uma espécie de federação de cidades (Ijebu, Egba, Ilesha), mas uma das cidades mais importantes era Ifé, reconhecida pelos iorubas como uma fonte mística de poder e legitimidade. O reino de Oió manifestava grande dinamismo conquistador ao longo de sua história (KiZerbo, 1999, p. 204).

Embora tenha permanecido fora da influência direta européia, como Estado escravista, o reino de Oió sentiu a decadência do comércio atlântico de escravos e se desintegrou em pequenas unidades políticas na primeira metade do século XIX, até cair sobre o controle britânico (os iorubas, atualmente, constituem cerca de $20 \%$ da população da Nigéria).

Mais distantes do litoral, as cidades de Tombuctu e Djenne não deixaram de ser, com a conquista marroquina de Songai, grandes cidades comerciais. O centro de expansão econômica acabou se desenvolvendo mais para o Leste, para as cidades hauçás (como Kano, Katsina e Zária) e para Bornu. A cidade de Kano era considerada um importante centro comercial e manufatureiro (sobretudo, produtos de couro).

Durante os séculos XVI e XVII, ocorreu um grande desenvolvimento das cidades hauçás. Já os sultões de Bornu acompanhavam com preocupação o desenvolvimento dos hauçás, a quem considera- 
vam vassalos. A organização social das cidades hauçás era urbanizada, nela moravam a nobreza, os letrados islamizados, os artesãos, tendo alcançado grande importância. A cidade de Kano já praticava o escambo da cola guineense com o sal dos mercadores do deserto. Os mercadores e missionários mandingas introduziram aí o islamismo, embora ele ficasse restrito à aristocracia.

No século XVIII, a África do Norte verificará um renascimento do islamismo, com a utilização da djihad (guerra santa). No início do século XIX, Usuman Dan Fodio (1754-1817), um xeque, poeta e pensador fula (fulani) que havia nascido no reino de Gobbir, iniciou sua luta contra a escravização dos muçulmanos e contra o sincretismo religioso da Hauçalândia. Em 1812, o Dan Fodio tornou-se califa do Império de Socotô. Diversas revoltas escravas no Brasil (como a dos Malês em 1835) tiveram influência da djihad de Usuman Dan Fodio. A construção de Estados nacionais africanos mostrava sua potencialidade, mas estaria submetido então à penetração européia no continente ao longo do século XIX.

\section{Considerações Finais}

Quando da chegada dos europeus à África, o continente encontrava diversas formações sociais, tendo o predomínio das variações de modo de produção comunitário e tributário. O resultado do comércio com os europeus foi a formação do sistema capitalista a partir do mercantilismo, com uma especialização e divisão internacional do trabalho, no qual os reinos africanos do litoral ficariam incumbidos basicamente de fornecer mão-de-obra escrava, além de poucos produtos extrativistas.

O deslocamento do centro de gravidade do comércio africano (da savana para a costa) refletiu, em certa medida, o deslocamento do centro de gravidade do desenvolvimento europeu (do Mediterrâneo para o Atlântico), no qual as relações África-Europa estariam submetidas agora ao quadro mais amplo de formação do capitalismo mercantilista, que desenvolveu desigualmente as formações so- 
ciais que engendrava. Assim, esses Estados africanos no início do século XVI foram embriões de nação destruídos pelo fim do comércio saariano e pela rearticulação atlântica.

O contato com os europeus interferiu e rearticulou diretamente diversas organizações políticas africanas em processo de formação/ aglutinação. Com a centralização de impérios, as novas organizações econômicas passaram a ter de contar com a variável das relações com os europeus, os quais poderiam se tornar aliados ou inimigos, em um complexo jogo que reunia alianças, federações e sucessão de domínios e hegemonias. Os caçadores de escravos iam buscar suas presas em diversos outros grupos e territórios. As conseqüências foram o desmantelamento de estruturas econômicas, políticas e sociais preexistentes, e os reinos que mais prosperaram foram, em geral, os escravistas, mas sobre uma frágil base. No começo do século XIX, o continente ainda não havia sido dominado. Mas, ao longo do século, o fim do escravismo colonial nas Américas, do mercantilismo e a rearticulação capitalista impulsionavam agora os europeus a penetrarem o continente africano, e esses reinos seriam obstáculo ao novo domínio imperialista a ser removido, destruído ou submetido.

\section{Referências}

AMIN, Samir. O desenvolvimento desigual: ensaio sobre as formações sociais do capitalismo periférico. Rio de Janeiro: Forense Universitária, 1976.

BERTEAUX, Pierre. África: desde la pre-historia hasta los estados actuales. Madrid: Siglo XXI, 1974.

COQUERY VIDROVITCH, C. A descoberta da África. Lisboa: Edições 70, 1981.

COSTA E SILVA, Alberto da. A enxada e a lança: a África antes dos portugueses. Rio de Janeiro: Nova Fronteira, 1992.

. A manilha e o libambo: A África e a escravidão, de 1500 a 1700. Rio de Janeiro: Nova Fronteira, 2002.

DEL PRIORE, Mary; VENÂNCIO, Renato Pinto. Ancestrais: uma introdução à História da África Atlântica. Rio de Janeiro: Elsevier, 2004. 
HERNANDEZ, Leila. A África na sala de aula: visita à História Contemporânea. São Paulo: Editora Selo Negro, 2005.

ILIFFE, John. Os africanos: história dum continente. Lisboa: Ed. Terramar, 1999.

KI-ZERBO, Joseph. História da Africa Negra. Lisboa: Europa América, 1999, 2 vols.

LOVEJOY, Paul. A escravidão na África: uma história de suas transformações. Rio de Janeiro: Civilização Brasileira, 2002.

OLIVER, Roland. A experiência africana: da pré-história aos dias atuais. Rio de Janeiro: Zahar, 1994.

RODNEI, Walter. Como a Europa subdesenvolven a África. Lisboa: Seara Nova, 1975. 


\section{AS SOCIEDADES AFRICANAS E O COLONIALISMO ${ }^{1}$}

\section{Tania Maria Seggiaro Chagastelles}

O desenvolvimento do capitalismo, a partir da primeira expansão européia, na fase quinhentista, levou à incorporação progressiva dos demais continentes ao sistema, de forma subordinada e dependente. As sucessivas hegemonias navais e comerciais - ibérica, holandesa e inglesa - marcaram a presença européia na América, na África e na Ásia.

$\mathrm{Na}$ América, constituíram-se as colônias-padrão da fase mercantilista. A África contribuiu com a mão-de-obra escrava. Com a Ásia, a Europa desenvolveu um lucrativo comércio de especiarias, além de estabelecer alguns enclaves coloniais de excepcional importância para o período seguinte.

No final do século XVIII, uma Era parecia apagar-se, com os movimentos que levaram à independência as colônias americanas e às restrições inglesas ao tráfico de escravos. A base teórica do imperialismo mercantilista - o monopólio - desaparecia diante da nova ideologia burguesa: o liberalismo.

O livre comércio tornou-se a bandeira de uma nova fase imperialista que inaugurava as primeiras décadas do século XIX com a presença britânica e francesa na África. Essa fase constitui o tema da primeira parte deste estudo. A segunda parte aborda a fase imperialista por excelência, a partir das décadas de 1870-80, quando ocorre a partilha propriamente dita do continente. Nessa fase, outras potências, como a Alemanha e a Itália, também procuram estabelecer colônias ou pontos estratégicos na África.

\footnotetext{
${ }^{1}$ Texto publicado originalmente sob o título "As sociedades afro-asiáticas e o colonialismo", na Revista Ciências e Letras (FAPA), n’ 33, em 2005.
} 


\section{A África no Século XIX}

Ainda no século XIX, a Europa não conhece a maior parte do continente africano. Com exceção do norte, banhado pelo Mediterrâneo e berço das antigas civilizações, o deserto do Saara esconde a África tropical que fornece, há séculos, ouro, marfim e, principalmente, escravos.

A região setentrional faz parte, no século XIX, do decadente Império Otomano. Dali, irradiou-se a influência islâmica para as regiões do deserto até os reinos do Sahel e para a costa oriental, da Somália ao Zanzibar. Nessa região, o grande atrativo para os europeus, especialmente britânicos e franceses, é o Egito, por sua localização estratégica na rota para o Oriente.

A África subsaariana permanece fechada em si mesma. Resistira à penetração européia durante séculos, permitindo apenas a ocupação de pequenas partes do seu litoral. A primeira expansão européia, no século XV, legara aos portugueses faixas litorâneas em Angola e Moçambique, ilhas em Cabo Verde, São Tomé e Príncipe. A Espanha ocupara uma faixa ao norte, no Marrocos, e a ilha de Fernando Pó, no Golfo da Guiné; a França, Saint-Louis, no estuário do Senegal; a Inglaterra, Fort James, na foz do Gâmbia; e os holandeses, a colônia do Cabo.

A hegemonia naval e comercial britânica levou-a a apoderar-se dos pontos mais estratégicos para a segurança de suas rotas. É assim que, no início do século, durante as guerras da Revolução Francesa, os ingleses tomam dos holandeses a colônia do Cabo, fundamental para a Rota do Oriente, e assumem uma posição no Gibraltar.

A era da primeira expansão européia, inaugurada pelos ibéricos e muito bem aproveitada pelos britânicos, encerrava-se. A Revolução Industrial, a Revolução Francesa e a independência das colônias americanas se fizeram em função da nova filosofia burguesa - $\mathrm{O}$ liberalismo. Este condena o sistema de exclusividade, consagra o livre-cambismo, a livre concorrência e a liberdade para o trabalho. 
Generaliza-se uma atitude pragmática de liberdade comercial, enquanto o regime de escravidão passa a ter seus dias contados.

A África negra, embora preservasse o seu território da presença branca, fora corroída pela intensidade do tráfico negreiro a partir do século XV - estima-se em mais de 100 milhões a sangria de seus habitantes em apenas quatro séculos.

Os efeitos de tal acontecimento ainda hoje são malcompreendidos e objeto de controvérsias. Não há dúvida, porém, de que os antigos impérios africanos foram desestruturados, provocando o surgimento de novas monarquias, cuja economia passou a basear-se na escravidão para o tráfico.

Ora, no século XIX, as restrições ao tráfico e, por fim, a abolição da escravidão e a ruína do artesanato diante dos produtos manufaturados europeus provocaram nova e dolorosa adaptação. A exportação de produtos agrícolas foi insuficiente para evitar a crise generalizada, manifesta na agudização de antigos antagonismos étnicos e regionais. Esta se manifesta bem antes da penetração oficial das nações européias, pois até meados do século parecia que a era colonial seria definitivamente relegada ao passado. $\mathrm{O}$ anticolonialismo era atitude comum não apenas a estadistas, como à própria opinião pública, que se agitava pela renúncia aos empreendimentos coloniais e em favor do self government (autogoverno). A era do ouro do liberalismo tem na Grã-Bretanha sua principal defensora, especialmente por ser a única nação industrializada e pelo fato de seus mercados não sofrerem séria ameaça de concorrência.

Alguns fatores, no entanto, conjugam-se para facilitar a partilha africana, de vez que proporcionaram o conhecimento do continente aos europeus, tão necessário à sua conquista: a atuação dos missionários e as expedições científicas.

Em 1815, havia apenas 200 missionários católicos fora da Europa. Em 1900, são 6.100. O mesmo acontece com os missionários protestantes, que são 16.000 em 1900. Trata-se de uma nova era de evangelização, inspirada por ideais humanitários e pela cruzada contra a escravidão, que abre rotas de penetração para o interior do continente. 
As expedições científicas são o resultado, por um lado, mais idílico, de uma literatura romântica de evasão que cria mitos - as ilhas, as florestas, os paraísos perdidos - e, de outro, da atuação das sociedades geográficas, tão em moda no século XIX. Desde o final do século XVIII, uma série de expedições foi financiada pela Real Sociedade de Geografia Inglesa. A cada expedição, a publicação dos relatos de viagem encanta o público: Mungo Park, Richard e John Lander, Richard Burton, John Speke e o mais famoso de todos - David Livingstone -, enterrado em 1873 com honras oficiais na abadia de Westminster. O norte-americano Henry Stanley é enviado, pelo New York Herald, à procura de Livingstone, há vários anos desaparecido. Seu livro How I Found Livingstone torna-se best-seller.

Enfim, o aspecto mais pragmático: todo o interior do continente e as bacias dos grandes rios africanos tornaram-se conhecidos dos europeus, facilitando uma penetração que fora, por séculos, evitada.

Ao conhecimento do continente, somam-se novas condições geradas pela Revolução Industrial e pelo progresso científico. O avanço da medicina tem importantes conseqüências para a Europa - sua população mais que dobra no decorrer do século -, mas também para o continente africano, que, por suas doenças tropicais, obtivera a fama de "túmulo do homem branco".

A Europa lança seus excedentes populacionais por todo o planeta, em um movimento migratório sem precedentes, formado especialmente por proletários que não encontram na sua pátria condições de sobrevivência. Por outro lado, na África subsaariana, pela primeira vez, o homem branco - missionários, cientistas, exploradores, comerciantes - sobrevive.

A evolução dos meios de transporte - o navio a vapor, a locomotiva - e dos meios de comunicação, como o telégrafo, completa o quadro favorável à expansão européia no continente africano. A queda no valor das taxas de frete e nas tarifas de transporte facilitou uma maior mobilidade não só para as mercadorias como também para as pessoas, além de elevar o papel das grandes companhias de navega- 
ção, as quais se ligam indissoluvelmente aos interesses coloniais. As estradas de ferro desempenharam papel semelhante e seus trilhos rasgam territórios acompanhados pelos postes telegráficos.

Nessa fase de prelúdio à conquista, ainda antes das décadas finais do século, as formas de penetração posteriores foram relativamente definidas, conforme as preferências européias e, do lado africano, de acordo com as regiões, suas características e reações.

As regiões ocidentais, fornecedoras de escravos aos europeus - Serra Leoa, Costa do Ouro, Nigéria, as regiões do Rio Congo a Angola - foram as que primeiro se adaptaram às novas exigências do capital, ainda na época do livre-cambismo, desenvolvendo uma economia exportadora em substituição ao tráfico negreiro. Ali, o óleo de palma foi o primeiro substituto para a economia baseada no tráfico. O delta do Níger, constituído pelos Oil Rivers (rios de óleo), atraiu os britânicos para a futura Nigéria, apesar da resistência dos iorubas.

As regiões do Rio Senegal atraíram o interesse francês para expansão do seu comércio ao interior, até o alto Níger e o Sudão.

Nas regiões orientais, de grande influência muçulmana, o controle comercial não era europeu, mas árabe, swahili ou indiano. Esses foram gradualmente deslocados, apoderando-se os europeus de suas rotas. Os ingleses, em um primeiro momento, apoiaram o sultanato de Zanzibar na região, rica pelo cultivo e comércio de especiarias, especialmente o cravo.

Convém assinalar que, nessa fase, os interesses europeus na África se achavam representados especialmente por britânicos e franceses, mas também, em menor grau, por italianos e alemães ou pelas duas nações remanescentes da primeira expansão européia, Espanha e Portugal.

Herança da presença holandesa no sul da África, os böers serão motivo de problemas para os colonos ingleses que aportam na colônia do Cabo, levando-os a anexar Natal em 1843. Na grande ilha de Madagascar, os interesses franceses desde o início do século colidem 
freqüentemente com os interesses comerciais dos ingleses, apreensivos com a rota do Cabo para o Oriente.

É no norte da África, contudo, que a presença européia se faz sentir mais forte. Desde a década de 1830, a França enviava colonos para a Argélia, e esse tipo de ocupação caracterizará as zonas do Magreb até a Líbia. Envia colonos à Tunísia, cobiçada pelos comerciantes marselheses; invade o Marrocos em 1844, chocando-se com os espanhóis e retirando-se por insistência e mediação inglesa. Dez anos antes, criara o governo-geral das províncias francesas no norte da África, procurando consolidar a efetiva ocupação da Argélia, que opõe resistência até meados dos anos 1870 .

O Egito, antigo palco das rivalidades franco-britânicas, constituiu, junto com a Tunísia, um dos territórios mais independentes do Império Turco, integrando-se ao sistema capitalista europeu como produtor de algodão. Mehemet Ali e seus sucessores aspiram à modernização das estruturas egípcias, aproximando-se de franceses e ingleses e aproveitando-se da sua rivalidade para contrair empréstimos e promover a construção do Canal de Suez.

O exemplo do Egito e da Tunísia é clássico e precursor de outros casos nos quais a invasão de capitais e empresas européias leva à crise, ao rolamento das dívidas e, como conseqüência de sua insolvência, ao controle internacional imposto pelos credores. A perda da soberania antecede, nesses casos, o domínio efetivo e oficial da potência colonizadora.

\section{A Nova Expansão Imperialista e o Continente Africano}

As profundas transformações que se operam no sistema capitalista a partir de meados do século serão responsáveis por uma radical mudança de atitude por parte dos estadistas e da opinião pública européia, que aderem ao Imperialismo. Vários fatores se conjugam e viabi- 
lizam essas transformações: revolução na técnica, que se reflete na produção industrial, com utilização de novas fontes de energia (petróleo, energia elétrica); a substituição do ferro pelo aço, as novas indústrias siderúrgicas, a produção de bens de capital, a produção em massa, a revolução nos transportes e nos meios de comunicação.

Concomitantemente, novas nações se industrializam e necessitam de mercado. A partir de 1873, já havia uma séria restrição da procura em relação à oferta. Aliás, esse ano inaugura uma longa depressão que durará vinte anos, durante os quais a crise indicou saídas - o monopólio e o protecionismo.

O processo de concentração do capital se faz em meio à crise, entre falências e acordos para sustentar os preços, inimagináveis no ideário liberal. Indústrias e bancos sofrem processo semelhante, e a aproximação de ambos gera o "capitalismo financeiro" - o capital bancário financia os grandes empreendimentos industriais, os quais se protegem formando associações monopolistas - cartéis, trustes, holdings...

As medidas protecionistas são a forma de defesa contra uma concorrência exacerbada entre as nações industrializadas. A Alemanha, a França (decreto de 1880), os Estados Unidos e, por fim, a própria Grã-Bretanha as adotam. O livre-cambismo é definitivamente enterrado, o que inaugura a era de acirramento dos nacionalismos e das rivalidades internacionais.

Ora, o período de crise e de profundas modificações no sistema capitalista coincide exatamente com os anos de maior expansão imperialista e de maior protecionismo.

Delineia-se uma doutrina imperialista, quase que unânime em sua aceitação, pelo menos na última década do século, alimentada pelas rivalidades internacionais, pela xenofobia e por obras pseudocientíficas que exploram a superioridade da raça branca.

A forma intermediária de atuação entre a liberdade comercial do período anterior, especialmente para os ingleses, esteve a cargo de um novo, mas bem conhecido tipo de companhias de carta-pa- 
tente, as quais tiveram curta duração, mas desempenharam importante papel como agentes do poder antes da efetiva entrada em ação dos Estados.

A Royal Niger Company, por exemplo, na sua breve existência de pouco mais de uma década, além de revelar-se muito rentável aos seus acionistas, foi responsável por uma prática que se tornará comum na partilha do continente africano - assinara mais de 400 tratados com os chefes indígenas. Ao tomar posse da região oficialmente, a GrãBretanha indenizou a Cia. em 22 milhões de libras.

Os alemães, por sua vez, na África, adotaram o sistema inglês, por iniciativa dos capitalistas Luderitz e Carl Peters. As maiores rivalidades entre a Deutsch Ostafrika e a British East African ocorrem na África Oriental, antes que acordos definam áreas de influência.

Os franceses continuaram com suas iniciativas individuais na África. A partir dos eixos estabelecidos no período anterior, a França expande-se: ao norte da Argélia para o oeste, chega ao Marrocos; ao leste até a Tunísia, que será anexada em 1881. Às rivalidades iniciais inglesas somam-se, agora, as alemãs e italianas, interessadas, respectivamente, no Marrocos e na Tunísia.

No Egito, onde constrói o Canal de Suez, inaugurado em 1869, a França estabelece um condomínio com a Grã-Bretanha, para administrar as finanças do país (1878). Três anos antes, por iniciativa de Disraelli, os britânicos adquiriram 7/16 das ações do Canal ao governo egípcio. Ali, uma reação nacionalista, liderada pelo coronel Arabi Pachá, é sufocada pelos ingleses, em 1882, bombardeando Alexandria e assumindo o controle da região. Como conseqüência, os ingleses passam a sustentar a política egípcia no Sudão e dali afastam os franceses.

$\mathrm{Na}$ África Ocidental, chocam-se os interesses franceses e ingleses (Royal Niger Company). O plano de Faidherbe, para a França, é unir os pontos extremos da navegação dos rios Senegal e Níger. Dos estabelecimentos costeiros do Senegal e da Guiné, os franceses expandem-se para o interior. Conquistam, ainda, a Costa do Marfim (1893) e o Daomé (1894). 
$\mathrm{Na}$ África Equatorial, a ação é de Savorgnan de Brazza, que funda Brazzaville (1881) na margem direita do Rio Congo. O Estado francês ratifica os tratados por ele firmados com os chefes nativos, estabelecendo um controle cada vez mais formal nas regiões de seu interesse. Aqui, as rivalidades acontecem entre Portugal, Alemanha e, especialmente, um novo personagem, de vital importância para o processo de partilha do continente - Leopoldo II, da Bélgica.

O soberano belga, interessado na região do Rio Congo para seus investimentos particulares, convocara, em 1876, a Conferência Geográfica de Bruxelas, criando uma Associação Internacional Africana. Em nome desta é contratado Henry Morton Stanley para a exploração das regiões do curso superior do grande rio, o que leva à criação do Comitê de Estudos do Alto Congo, o qual será transformado, em 1879, na Associação Internacional do Congo.

As rivalidades na região levaram à realização, entre 1884-85, da Conferência de Berlim, marco histórico do imperialismo contemporâneo. Sob o disfarce de objetivos humanitários, a conferência reúne vários países europeus, com maior ou menor interesse pelo continente africano, aos quais se unem o Império Turco e os Estados Unidos da América. Nenhuma ação independente africana foi convidada a participar dos assuntos que diziam respeito, diretamente, aos seus territórios.

Invocando Deus no seu primeiro parágrafo, o documento que resultou da Conferência pouco cuidou dos objetivos humanitários iniciais, mas estabeleceu "regras" a serem observadas pelas potências signatárias para apropriação "legal" dos territórios africanos. Esta passaria, em primeiro lugar, pela ocupação efetiva do território e, logo após, pela comunicação às demais potências e sua ratificação.

O Estado Livre do Congo foi reconhecido pelos participantes da Conferência e Leopoldo, aclamado seu chefe. Portugal mantinha um pequeno enclave na região - Cabinda -, enquanto a França obtinha como "esfera de influência" a margem direita do Congo.

Reconhecidas foram, ainda, esferas de influência da Alemanha, tanto na costa ocidental como na oriental da África, onde logo esta- 
belecerá suas colônias - Togo, Camarões, a África Oriental Alemã e o Sudoeste Africano.

A Inglaterra teve seus interesses reconhecidos nos Oil Rivers do delta do Níger e, principalmente, o domínio absoluto da África Meridional.

Após definir suas áreas de influência assinando tratados com dirigentes africanos, a contestação possível dessas áreas era contornada através de acordos ou tratados que as potências européias realizavam entre si. Estes liquidaram com as rivalidades anteriores e definiram as esferas de influência metropolitanas e o mapa africano até a $1^{\text {a }}$ Guerra Mundial.

As últimas rivalidades entre franceses e alemães no Marrocos foram resolvidas em 1912, e a França estabeleceu um protetorado sobre o país. A Itália, que já ocupara parte da Eritréia e da Somália, sofre uma espetacular derrota, em 1896, quando tentava a conquista da Etiópia. Em 1911, a região da atual Líbia torna-se uma colônia italiana. Portugal mantém Angola e Moçambique, enquanto o Congo torna-se propriedade do governo belga.

Neste último capítulo da partilha, ao lado dos tratados entre europeus e africanos, que muitas vezes resultaram em fraude imposta pelos primeiros, registra-se o fato de que, em boa parte dos casos, a conquista se efetivou militarmente, o que pressupõe uma resistência dos povos africanos à perda de sua soberania.

Um espetacular desenvolvimento da indústria de armamentos deu incomparável superioridade militar aos europeus. Isso ocorreria no exato momento em que o imperialismo ganhava força. As metralhadoras - a Maxim e a Gatling - serão decisivas para a conquista militar européia. A resistência, por outro lado, deu lugar a lutas anticoloniais célebres, como a Bilundu, em Angola, a Maji-Maji, na África Oriental Alemã, ou a Hut Tax War, na Serra Leoa.

A França, a partir dos anos 1880, põe fim, pela força das armas, a encarniçadas resistências, como a de Samori Touré, Ahmadu, LatDior ou Rabah de Sennar. Quase todos combateram, na defesa dos seus territórios, até a morte. 
Os ingleses, na África Ocidental, só conseguiram vencer a resistência dos achântis em 1901. Na África Oriental, Uganda e Quênia inspiraram o recurso militar, mas foi a reconquista do Sudão, em 1898, o episódio mais sangrento - mais de 20.000 sudaneses morreram em combate.

A África Meridional representa não só o exemplo de uma grande resistência negra - a Zulu -, mas também um dos poucos casos em que brancos chegaram a guerrear entre si: ingleses e böers.

A rivalidade entre ingleses e böers aumentou com a descoberta de ouro e diamantes na região. Os ingleses fizeram grandes inversões de capital, o que resultou em uma demanda maciça de mão-de-obra negra e no surgimento de uma rica oligarquia local, da qual será originário Cecil Rhodes. Este fundou e administrou a Gold Fields of South Africa, para explorar o ouro, e a De Beers Consolidated Mines, para exploração de diamantes. Detentor dos direitos da Companhia Britânica da África do Sul, obteve os poderes que lhe permitiram a anexação de vários territórios.

A guerra anglo-böer resultou em perda momentânea para estes últimos, mas, em 1909, foi criada a União Sul-Africana, que irá reconhecer duas línguas oficiais: a inglesa e a africander (böer). A preponderância política böer se firmará no período entre guerras, moldando uma sociedade que terá como característica a extrema segregação dos grupos nativos no Apartheid.

\section{Referências}

ARRIGHI, Giovanni; SILVER, Beverly J. Caos e governabilidade no moderno sistema mundial. Rio de Janeiro: Contraponto / Ed. UFRGS, 2001.

BOAHEN, A. Adu (Coord.). História geral da África. São Paulo: Ed. Ática/ UNESCO, 1991. Volume 7 - A África sob dominação colonial, 1880-1935.

DAVIDSON, Basil. Os africanos - Uma introdução à sua história cultural. Lisboa: Edições 70, 1969.

FERRO, Marc. A manipulação da História no ensino e nos meios de comunicação. São Paulo: IBRASA, 1983. 
FIELDHOUSE, David K. Los impérios coloniales desde el siglo XVIII. Madrid: Siglo XXI, 1974.

KI-ZERBO, Joseph. História da África negra. Portugal: Ed. Europa, [sd.].

LÊNIN, V. I. O Imperialismo, fase superior do capitalismo. In: Lênin, obras Escolbidas. São Paulo: Alfa-Ômega, 1979. Volume 1.

MACKENZIE, J. M. A partilha da Africa 1880-1900. São Paulo: Ed. Ática, 1994. MIÉGE, Jean-Louis. Expansión europea y descolonización. De 1870 a nuestros dias. Barcelona: Labor, 1980.

RODRIGUES, João Carlos. Pequena história da África negra. São Paulo: Ed. Globo, 1990.

SCHNERB, Robert. O século XIX. In: História geral das civilizações. São Paulo: Difusão Européia do Livro, 1969. Volume VI. 


\section{INDEPENDÊNCIA, MARGINALIZAÇÃO \\ E REAFIRMAÇÃO DA ÁFRICA \\ (1957-2007)}

\section{Paulo Gilberto Fagundes Visentini}

A descolonização da África negra foi tardia e relativamente controlada, pois as potências coloniais se anteciparam à radicalização dos protestos e puderam encaminhar as independências. Estudantes oriundos das elites locais foram enviados para estudos superiores nas metrópoles, a administração tornava-se paulatinamente africanizada e assessorada por técnicos europeus, enquanto a autonomia política era concedida progressivamente a uma burguesia nativa previamente cooptada.

Os primeiros países africanos a se libertarem, entretanto, foram os que mais lutaram para escapar do neocolonialismo. Em 1957, Gana independizou-se da Inglaterra, e o Primeiro-Ministro Nkrumah adotou uma política de neutralismo ativo, aproximou-se da URSS e da China Popular e declarou-se partidário do Pan-africanismo. No ano seguinte, a Guiné separou-se da França, e o Primeiro-Ministro Sekou Touré recebeu apoio dos países socialistas por sua linha política próxima à de Nkrumah.

Em 1960, o "ano africano", a maioria dos países do continente tornou-se independente da França e da Grã-Bretanha, dentro da linha "pacífica", gradual e controlada: Camarões, Congo-Brazzaville, Gabão, Chade, República Centro-africana, Togo, Costa do Marfim, Daomé (atual Benin), Alto Volta (atual Burkina Fasso), Níger, Nigéria, Senegal, Mali, Madagascar, Somália, Mauritânia e Congo-Leopoldville (atual Zaire). Entre 1961 e 1966 foi a vez de Serra Leoa, Tanzânia, Uganda, Ruanda, Burundi, Quênia, Gâmbia, Botswana e Lesoto. Todos os novos Estados localizavam-se na zona tropical africana 
e, neles, era limitado o número de colonos europeus, o que facilitou a transferência do controle formal dos diversos países à burguesia e classe média negra.

Nem tudo, entretanto, correu tão tranqüilamente. No CongoLeopoldville, os belgas abandonaram precipitadamente o país assim que eclodiram os primeiros distúrbios. Patrice Lumumba, líder nacionalista e progressista congolês, foi assassinado durante a guerra civil por Mobutu, que implantou um regime neocolonial.

Vários Estados africanos, face à sua debilidade, tentaram associarse em nível continental, dentro dos postulados pan-africanistas, ou federar-se pragmaticamente em escala regional, mas a falta de mínimas condições objetivas impediu a realização dessas aspirações. Apesar das divergências existentes na Conferência de Addis Abeba, em 1963, foi criada a Organização da Unidade Africana (OUA), com comissões para arbitramento de conflitos e comitês de libertação para os territórios ainda submetidos. A OUA aprovou como regra para a África a manutenção das fronteiras herdadas do colonialismo, diante da absoluta falta de outros parâmetros para delimitação dos novos Estados.

A maioria dos países francófonos manteve alguns vínculos com a ex-metrópole através da Comunidade Francesa de Nações, e os anglófonos com a Commonwealth britânica. Além disso, quase todos os demais assinavam acordos bilaterais com a antiga potência colonial ou com os EUA, abarcando várias áreas de cooperação. No campo militar, efetivavam-se, através da venda de armas, treinamento de oficiais e presença de assessores e missões. No plano cultural, o intercâmbio fazia com que até as cartilhas de alfabetização viessem da Europa, onde também estudavam os jovens da elite, futuros administradores do país.

Quanto à economia, não só a dependência externa enquanto países exportadores de matérias-primas e produtos primários implicava a manutenção de vínculos de subordinação, agora modernizados, como no plano interno permaneciam quase inalterados os sistemas de produção e preservavam-se os interesses estrangeiros. A ca- 
rência tecnológica e a falta de técnicos tornavam esta subordinação estrutural. No tocante à diplomacia, a maioria das jovens nações africanas tinha pouca margem de manobra, devido à falta de recursos e à dependência externa. Esses fatores serviam para configurar uma relação tipicamente neocolonial.

Os problemas africanos eram imensos. As fronteiras desses países eram artificiais, tanto no que se refere ao mínimo critério de racionalidade geoeconômica como histórico-cultural. Grupos etno-lingüísticos rivais eram reunidos em um mesmo Estado, enquanto outros afins encontravam-se separados por uma linha traçada à régua no mapa. O Estado antecedia à existência de uma nação. $\mathrm{Na}$ ausência de um idioma comum, oficializava-se o do ex-colonizador, enquanto a massa camponesa analfabeta continuava a utilizar os diversos dialetos tribais. As rivalidades entre os distintos grupos haviam sido estimuladas pelos colonizadores como forma de dominação, e deixavam uma herança trágica, expressa no problema das minorias e do "tribalismo", além do antagonismo entre assimilados à cultura européia e não-assimilados. A ausência de médicos, engenheiros, administradores e professores somava-se a uma estrutura de classes fragmentada, nos marcos de uma economia controlada de fora (exceto as extensas áreas ainda na fase da subsistência). A precaríssima rede de transportes ligava apenas os enclaves exportadores aos portos, inexistindo qualquer integração nacional.

Contudo, muitos dos constantes golpes de Estado, perpetrados pelo exército, possuíam um caráter progressista e modernizador, pois a instituição era uma das poucas de expressão nacional, acima das divisões tribais e em contato com a realidade social do país - embora a maioria deles não conseguisse implementar seu programa. Da mesma forma, a quase duplicação do número de Estados existentes em apenas uma década, apesar da fragilidade dos mesmos, não deixou de alterar profundamente as relações internacionais, transformando o caráter da ONU e reforçando o Movimento dos Não-Alinhados. 


\section{As Independências Revolucionárias \\ e a Guerra Fria}

A descolonização da África no início dos anos 1960 deixou de fora os chamados "bastiões brancos" do sul do continente. Portugal, que servia de "testa de ferro" aos interesses econômicos transnacionais, recusou-se a independizar Angola e Moçambique. A África do Sul, governada pela minoria branca ( $20 \%$ da população), controlava a Namíbia e na Rodésia (atual Zimbábue), os colonos brancos (5\% da população) apoiaram Ian Smith na proclamação da independência em 1965, a qual não foi reconhecida por Londres. A África do Sul, onde a segregação racial do Apartheid estava consagrada na Constituição, possuía grande força econômica e estava associada aos capitais estrangeiros e às empresas transnacionais. A África Austral, em seu conjunto, possuía imensas reservas de minerais estratégicos e potencialidades agrícolas, além de deter uma posição geopolítica estratégica na rota entre o Oceano Atlântico e Índico.

$\mathrm{Na}$ África Portuguesa, após quinze anos, a luta armada também seria coroada por uma vitória. Em Moçambique, a guerrilha implantara-se no norte, na fronteira com a Tanzânia. A Frente de Libertação de Moçambique (FRELIMO), dirigida por Samora Machel, já controlava parte do país, quando a Revolução dos Cravos em Portugal (1974) precipitou os acontecimentos. Moçambique passou a ser governado por um movimento predominantemente negro, que se proclamava marxista-leninista, junto às fronteiras da Rodésia e da África do Sul, países ainda controlados por minorias coloniais, onde intensificava-se a luta armada. Em 1976, ocorria o Levante de Soweto, duramente reprimido pelo Apartheid. As pequenas colônias portuguesas da Guiné-Bissau, de Cabo Verde e São Tomé e Príncipe também independizaram-se com governos populares.

A independência de maior impacto, entretanto, foi a de Angola, com maiores potencialidades econômicas e com expressiva minoria branca - o país dispõe de petróleo, ferro, diamantes, entre outros 
minerais estratégicos. A divisão e o confronto entre os três grupos que lutavam pela independência acirraram-se ainda mais quando da derrocada do fascismo português. A Frente Nacional de Libertação de Angola (vinculada aos EUA) e as tropas do Zaire avançaram do norte para atacar a capital, Luanda, onde o Movimento Popular para a Libertação de Angola (MPLA) era dominante. A invasão foi derrotada pelo MPLA com apoio de instrutores cubanos, que começavam a chegar ao país. Entretanto, no sul os grupos da União para a Independência Total de Angola (UNITA) e o exército sul-africano desencadearam uma guerra-relâmpago contra o MPLA de Agostinho Neto.

Face à situação desesperadora, iniciou-se uma ponte aérea entre Havana e Luanda, com o envio de armas e vinte mil soldados. No centro do país, as tropas cubanas (a maioria descendente de ex-escravos) e do MPLA derrotaram o exército sul-africano, um dos melhores do mundo. Assim, o MPLA governaria sozinho o país, havia declarado uma República Popular de inspiração marxista-leninista, mas enfrentava a guerrilha étnica da UNITA no sul, liderada por Jonas Savimbi (ligado a Pretória e Washington). A África do Sul ocupou uma faixa do sul de Angola para manter viva a UNITA, desestabilizar o governo do MPLA e impedir a infiltração dos guerrilheiros da Organização Popular do Sudoeste Africano - SWAPO (apoiados por Luanda) na Namíbia. Os cubanos permaneciam um pouco ao norte dos sul-africanos para impedir a invasão ao centro do país. A situação dos novos Estados era difícil, pois a maioria dos colonos retirara-se, privando-os de capitais, técnicos e administradores, enquanto tinham de enfrentar o caos interno e as invasões externas.

Na Etiópia, castigada pela miséria, seca e pelas guerrilhas muçulmanas e esquerdistas na Eritréia, o velho imperador pró-americano Haile Selaissie foi derrubado em 1974 por um golpe militar com apoio popular. A junta militar (DERG) exprimia um populismo pouco definido, enquanto as oposições, o caos e as tendências centrífugas ameaçavam a existência do novo regime. Este, enquanto crescia a luta de facções dentro do grupo dirigente, ligava-se cada vez mais às corren- 
tes de esquerda e implementava uma ampla reforma agrária, mobilizava a população, rompia com os EUA e enfrentava os movimentos de oposição. Em 1977, ascendeu à direção do DERG o coronel Mengistu Haile Marian (formado nos EUA). Enquanto definia-se pelo socialismo, as rebeliões separatistas ou autonomistas agitavam quase todas as províncias, e a Somália, país que, apesar de proclamar-se socialista e ser aliado da URSS, atacou a Etiópia, da qual Moscou acercava-se.

$\mathrm{Na}$ África Austral, a mobilização negra e os atentados do CNA intensificavam-se, apesar da crescente repressão e militarização do Estado sul-africano. Entretanto, o grande evento na região foi a ascensão ao poder da ZANU (União Nacional Africana do Zimbábue) na Rodésia, através de eleições patrocinadas pela Grã-Bretanha. Sem condições de derrotar a guerrilha negra, a minoria branca apelou para a mediação da ex-metrópole. O novo presidente, o marxista Robert Mugabe, formou um governo de coalizão com a ZAPU (União do Povo Africano do Zimbábue) e teve a habilidade de oferecer garantias aos brancos e a suas empresas, os quais permaneceram no país, mantendo sua prosperidade e permitindo o encaminhamento de reformas favoráveis à maioria negra. $\mathrm{O}$ país voltou à denominação africana de Zimbábue. Essa original revolução africana deixou a África do Sul isolada na região, embora esse país castigasse os vizinhos com freqüentes ataques de comandos e bombardeios.

\section{A Marginalização da África}

Na segunda metade dos anos 1980, as conseqüências dos conflitos africanos, da Nova Guerra Fria e da reestruturação da economia mundial continuavam a agravar-se. A União Soviética e os regimes revolucionários do continente, seus aliados, encontravam-se numa posição cada vez mais difícil. Assim, quando Gorbachov chegou ao poder em 1985, procurou buscar um entendimento com os EUA. Em troca da redução da corrida armamentista, a URSS passou, 
em fins de 1987, a pressionar seus aliados regionais a buscar uma acomodação política. Já na África do Sul, a situação foi mais complexa. Em 1988, as tropas cubano-angolanas derrotaram de forma esmagadora forças regulares sul-africanas e da UNITA em Cuito-Cuinavale no sul de Angola, e a aviação cubana atacou a represa que fornecia energia ao norte da Namíbia. Ficava patente para a própria África do Sul, extremamente desgastada pela guerra, que era hora de negociar. Os americanos propunham o princípio do Linkage: a retirada cubana em troca da independência da Namíbia, que Pretória acabou aceitando, ainda que procurando ganhar tempo.

Em 1989, os cubanos retiraram-se de Angola (e do resto da África), no mesmo ano em que o muro de Berlim era aberto, iniciandose o difícil processo eleitoral na Namíbia, sob os auspícios da ONU. Depois de se estabelecerem prerrogativas especiais para a minoria branca e para o capital internacional, ocorreram eleições que foram vencidas pela SWAPO. Em março de 1990, a Namíbia tornou-se independente. Ao mesmo tempo, os ventos democratizantes, associados ao reordenamento mundial, varriam a África. Regimes de partido único eram substituídos, frente às pressões internas e externas, por sistemas liberal-democráticos multipartidários. Estados em guerra civil como Angola (maio de 1991) e Moçambique (outubro de 1992) assinavam acordos de Paz, e os demais regimes marxistas eram derrubados, como na Etiópia em maio de 1991. A própria África do Sul anunciou, em fevereiro do mesmo ano, o fim do Apartheid, após a libertação do líder negro Nelson Mandela no ano anterior.

A adequação da África aos parâmetros da chamada Nova Ordem Mundial, contudo, não significava a solução dos problemas existentes. O fim da bipolaridade e do próprio conflito Leste-Oeste, agravado pelo desmembramento e desaparecimento da União Soviética em fins de 1991, fez com que o continente africano perdesse sua importância estratégica e capacidade de barganha, ao que se acrescentava a própria perda de importância econômica. A Guerra do Golfo, por sua vez, reforçara esta tendência. O resultado foram a marginalização da África no 
sistema internacional e a desestrategização e tribalização dos conflitos e da política regional. Com armas menos modernas, financiamento das máfias e senhores da droga (cujo cultivo se expandia rapidamente em muitas regiões do continente), e intromissão de potências médias locais e externas, esses conflitos persistiram, até como forma de sobrevivência das elites e das populações nas áreas mais afetadas. Alguns acordos de paz, como os de Angola, não foram respeitados, com a persistência da guerra e a devastação de amplas regiões.

A instabilidade no continente também afetou os Estados do Golfo da Guiné. O mais importante país da região, a Nigéria, viveu, ao longo dos anos 1990, uma turbulência política interna permanente, com a oscilação entre avanços eleitorais da oposição e novos golpes militares. Além disso, as guerras civis alastraram-se pela região: Senegal (região de Casamance), Libéria, Serra Leoa e a longa guerra dos Estados do Sahel (Mali, Níger, Mauritânia e a própria Argélia) contra os nômades tuaregues do deserto. Embora a OUA tenha criado forças de paz para barrar os conflitos da Libéria e Serra Leoa, ainda não conseguiu debelar esses conflitos. Nestes, a fratura principal ocorre entre os nativos do interior e os descendentes ocidentalizados de ex-escravos das Américas, que retornaram à África no século XIX, e habitam o litoral. Acrescente-se a isso que, após uma breve redemocratização, muitos regimes autoritários estão voltando ao poder na África, ou pelo menos antigos ditadores vencem eleições ou reassumem na esteira de conflitos internos, geralmente com apoio popular.

Apesar desses problemas, existem alguns processos positivos que sinalizam a reafirmação da África na cena internacional. É o caso da África Austral, outra região considerada importante no contexto da globalização, devido a suas reservas minerais e sua relevante posição geopolítica. Tanto aqui como no Oriente Médio, os conflitos regionais conduziam à radicalização social, à instabilidade diplomática e aos excessivos gastos em defesa e segurança, os quais foram consumindo as riquezas locais, obrigando o Ocidente a auxiliá-las economicamente. O Apartheid começou a ser desativado pelo presidente Frederik De Klerk, 
em um tortuoso processo que culminou com a eleição de Nelson Mandela à presidência do país em 1994. Esse caminho foi difícil, com inúmeros conflitos internos, o que também veio a ocorrer com os processos de paz em Angola e Moçambique, este último pacificado em 1992, enquanto o primeiro só teve a guerra encerrada uma década depois, quando o isolado Jonas Savimbi veio a falecer, desmobilizando-se as últimas facções da UNITA. Mas o problema das minas terrestres e da infra-estrutura destruída ainda levará tempo para ser resolvido.

Outro processo que representa uma renovação e desentrave da política africana resultou da guerra civil de mútuo extermínio em Ruanda e Burundi. Esse conflito foi mostrado pela mídia como uma decorrência do "tribalismo tradicional", mas, na realidade, resultou da deformação e reapropriação moderna de determinadas fraturas sociais da região. Os agricultores hútus formam quase $90 \%$ da população, enquanto os pastores tútsis, que chegaram mais tarde à região e constituíram uma aristocracia, representam 10\%. Durante a ocupação alemã e belga nessas duas colônias, os tútsis foram cooptados como elite no poder. Após a independência, o regime neocolonial de Ruanda passou a ser dominado pelos hútus e aliou-se incondicionalmente à França e ao Zaire. A hegemonia hútu, marcada por forte corrupção e exclusão estrutural dos adversários, começou a ser questionada no início da década. Refugiados tútsis, exilados há anos em Uganda, organizaram um pequeno exército (a Frente Patriótica Ruandesa - FPR), que penetrou no norte de Ruanda em outubro de 1990, sendo expulsos um mês depois pelo exército. Sentindo-se desgastado e ameaçado internamente, o governo massacrou tútsis em 1991 e 1992, como meio de fomentar uma divisão étnica, com vistas a permanecer no poder.

Apesar da assinatura dos Acordos de Arusha entre o governo e a oposição, a guerra civil foi reiniciada, com os rebeldes consolidando seu controle no norte e massacrando populações hútus. Frente ao impasse reinante no campo de batalha, no verão de 1993 foi estabelecido um governo de coalizão. Mas a paz estabelecida era frágil, e bastou que um hútu vencesse as eleições na vizinha Burundi para le- 
var os tútsis deste país a reagir. Em Ruanda, então, os extremistas hútus, ligados ao ex-presidente, aproveitaram-se da situação para atacar os tútsis e os hútus moderados. A crise agravou-se com a morte dos presidentes dos dois países, quando foi derrubado sobre Ruanda o avião que os transportava para uma reunião, destinada a resolver a crise. A partir daí, a guerra civil acirrou-se, e a FPR conquistou Kigali, a capital de Ruanda. Em 1994, teve início, então, um gigantesco massacre de hútus, que fez entre 500 mil e 800 mil mortos, e produziu um êxodo de 4 milhões de refugiados (numa população de 7,8 milhões), a maioria em direção aos países vizinhos, principalmente o fragilizado Zaire, que, junto com a França, era aliado do antigo governo. Os Estados Unidos imediatamente reconheceram o novo governo da FPR, que era também aliado de Uganda e Tanzânia.

O problema dos refugiados gerou tensões no Zaire, país que já enfrentava graves problemas internos, após malogradas tentativas de democratização. Em 1996, formou-se na região dos lagos, no leste, a Aliança das Forças Democráticas para a Libertação do Congo-Zaire, uma milícia composta principalmente por tútsis do Zaire. A Aliança era liderada por Laurent Kabila, um negociante de ouro e marfim, associado a meios empresariais norte-americanos, e que fora partidário de Lumumba no início dos anos 1960. Em menos de quatro meses, os rebeldes avançaram pelas províncias ricas do país até a capital, Kinshasa, sendo absorvidos por um vácuo, praticamente sem encontrar resistência. Obviamente, o Zaire de Mobutu era um gigante de pés de barro em desagregação, mas isso não era um fenômeno recente. Ele teria sobrevivido mais tempo, não fossem certos fatores externos.

Durante a Guerra Fria, a África fora uma área de influência predominantemente européia, com a França exercendo o papel de gendarme. Com a solução negociada dos conflitos regionais na passagem dos anos 1980 aos 1990, ironicamente os antigos Estados marxistas africanos, anteriormente aliados da URSS e inimigos da França, voltaram-se para os EUA, que abriram um espaço de influência direta no continente. Essa atitude revelava a profundidade das rivalidades regionais, entre os regi- 
mes marxistas e os pró-franceses. Apesar do fracasso na Somália, Washington passou a exercer influência direta sobre a Etiópia, Eritréia, Uganda, Angola e Moçambique, além da presença prévia no Quênia. Como resultado do conflito tútsis x hútus, essa projeção estendeu-se a Ruanda, Burundi e ao leste do Zaire, em detrimento da influência francesa.

\section{A Reafirmação: \\ a União Africana e o NEPAD}

As tendências de reafirmação da África no sistema mundial, as quais se esboçaram na segunda metade dos anos 1990, se aprofundaram na passagem do século. Apesar disso, os conflitos étnico-tribais e as guerras civis se mantiveram, atingindo, muitas vezes, níveis extremos de violência. Essa situação foi mais comum especialmente nos Estados do Golfo da Guiné e da África Ocidental. Na Libéria, os conflitos entre as populações do interior e as mais ocidentalizadas do litoral prosseguiram de forma intermitente, e na Serra Leoa, em 1999, o mesmo problema começou a se manifestar com intensidade. As populações do litoral, em grande parte descendentes de ex-escravos retornados das Américas, constituem a elite dirigente, discriminando os nativos. Alguns grupos políticos ou tribos, por outro lado, são financiados pelas grandes companhias de diamantes (particularmente as localizadas em Antuérpia) e outras pedras preciosas, com o objetivo de manter o controle das zonas de mineração, devido ao literal colapso do Estado e à desordem reinante.

Tudo isso agrava as tensões locais e propicia uma espécie de "privatização" da política e da violência armada, em meio a todo o tipo de tráfico, particularmente o de drogas, que tem crescido na África. A Nigéria, por sua vez, é conhecida por possuir uma poderosa máfia de narcotráfico, que já atua em todo o mundo. O fim do regime autoritário neste populoso país africano, por seu turno, tem propiciado ao país um maior protagonismo regional, como a participação em missões de paz da União Africana, embora persistam dificuldades sociais, apesar 
da imensa renda petrolífera. Outro país atingido por uma guerra civil foi a Costa do Marfim, onde os rebeldes apoderaram-se da metade norte do país em 2003, em sua luta contra o governo, tendo sido necessária uma intervenção francesa em apoio do mesmo.

Por outro lado, o processo de implantação de inúmeras democracias após a queda do Muro de Berlim, impulsionadas de fora para dentro através daquilo que Samuel Huntington denominou de "Terceira Onda" (a das democracias), parece estar retrocedendo. Antigos líderes de regimes autoritários de esquerda começaram a retornar ao poder. Com a guerra civil de 1997-1998, Denis Sassou Nguesso voltou ao poder na República Popular do Congo, com o apoio da empresa petrolífera francesa Elf-Aquitanie, em uma clara tentativa de rechaçar os interesses norte-americanos defendidos pelos regimes "democratizados". Mas o caso mais espetacular foi o fim da longa guerra civil em Angola, após a morte em combate do líder da UNITA, Jonas Savimbi, ocorrida em fevereiro de 2002. Savimbi controlava as minas de diamante do interior e devastava o país, enquanto o governo retirava seu rendimento do petróleo do litoral.

A África do Sul pós-Apartheid também tem promovido ativamente o multilateralismo no continente africano. A SADCC, Coordenação da Cooperação para o Desenvolvimento da África Austral, foi transformada em 1992 em Comunidade para o Desenvolvimento da África Austral -SADC - , com atribuições mais concretas e adesão de novos países, dinamizados pela entrada da África do Sul. ${ }^{1}$ Em setembro de 2001, a organização, que promove uma ativa integração na região, aprovou a criação de uma área de livre comércio entre os países-membros até 2008. A Organização da Unidade Africana, por sua vez, foi transformada em União Africana em julho de 2002. O apoio sul-africano e os recursos prometidos pelo líder líbio Kadafi (que já não está mais sob embargo internacional) foram decisivos para a ampliação dos objetivos da organização e a

\footnotetext{
${ }^{1}$ São membros África do Sul, Lesoto, Suazilândia, Botswana, Namíbia (estes países integram também a SACU, União Aduaneira da África Austral, fundada em 1910), Moçambique, Zimbábue, Malawi, Tanzânia, Maurício, Zâmbia, Angola, República Democrática do Congo e Madagascar.
} 
criação de condições para uma cooperação mais íntima entre os países do continente e para uma verdadeira integração. O presidente Mbeki, sucessor de Mandela, apoiou também a NEPAD, Nova Parceria Econômica para o Desenvolvimento Africano. Tudo isso contribuiu para que algumas eleições transcorressem com tranqüilidade, como a do Quênia e a de Madagascar, vencidas pela oposição, esta última apoiada pelos EUA.

Mas a África também passou a integrar os grandes temas e problemas mundiais. Epidemias devastadoras, como o vírus ébola e o HIVAIDS, não apenas causam danos presentes, como também comprometem o futuro, pois os infectados pelo último chegam a atingir 50\% em Botswana e 25\% na África do Sul. Ao lado de problemas no campo da saúde, existe uma dimensão social e econômica que se tornará mais aguda com o passar do tempo. Além disso, há guerras civis, fomes, destruição ambiental e narcotráfico, e o continente foi cenário de acontecimentos ligados à grande política mundial. Em julho de 1998, ocorreram atentados terroristas simultâneos nas embaixadas norteamericanas do Quênia e da Tanzânia, com um saldo de 250 mortos e 5000 feridos. O atentado teria sido articulado pela rede $\mathrm{Al}$ Qaeda, o que levou o então presidente norte-americano, Bill Clinton, a atacar com mísseis os campos de treinamento da mesma no Afeganistão.

Ao mesmo tempo, graças ao grande protagonismo diplomático da África do Sul, o continente passou a sediar algumas Conferências Internacionais da ONU. Em 2003, a União Africana tomou posição frontalmente contrária a qualquer ataque ao Iraque. Assim, a África, lentamente, vai se reafirmando e recuperando certo poder de barganha, como foi visto no caso do Iraque, quando os membros africanos do Conselho de Segurança da ONU foram cortejados pelos EUA e pela França. A liderança sul-africana e o retorno da Líbia ao cenário regional são elementos importantes, ao lado da afirmação das organizações multilaterais regionais e continentais.

A China também tem se feito presente no continente negro, tanto por razões econômicas (mercados e matérias-primas) quanto diplomáticas (combater a presença de Taiwan). Em novembro de 2006, foi reali- 
zada em Beijing a primeira Cúpula China-África, com a presença de mais de quarenta líderes africanos e o lançamento de uma espécie de "Plano Marshall" chinês para o continente, com investimentos em infra-estrutura e ajuda ao desenvolvimento. Isso tem sido acompanhado por um maior protagonismo francês. A histórica visita do ex-presidente da França Jacques Chirac à Argélia, em março de 2003, constitui um signo dessa tendência e sinaliza para a possibilidade desse importante país afro-árabe encerrar sua guerra civil e voltar a ter um maior protagonismo econômico e diplomático nos assuntos africanos. Por fim, o bloqueio da situação no Oriente Médio indica que a África poderá ter um papel mais relevante, na medida em que constitui uma retaguarda geopolítica dessa região. Ao mesmo tempo, o estabelecimento de laços com o Mercosul, com a Ásia e com a União Européia propiciará, a médio prazo, melhores condições para a África.

\section{Considerações Finais}

Nesse contexto, percebem-se algumas peculiaridades no convulsionado processo histórico africano e que precisam ser desmistificadas, tentando-se compreender os entraves e as potencialidades da inserção deste continente no sistema internacional do século XXI. Em primeiro lugar, é preciso descartar a visão segundo a qual a África é um continente voltado ao passado, em um contexto de conflitos insolúveis, e mesmo irracionais do ponto de vista ocidental. As sociedades africanas estão passando por um processo semelhante ao atravessado por outras regiões do mundo, qual seja, a construção dos modernos Estados nacionais.

Muito do que os europeus consideram absurdo na África constitui apenas a imagem contemporânea de processos semelhantes aos de seu próprio passado nem tão remoto. Quem se sente chocado pelas guerras de perfil étnico-tribal simplesmente esqueceu os sangrentos conflitos religiosos e proto-nacionais das monarquias dinásticas européias, a construção pela força dos Estados nacionais europeus, 
os quais esmagaram os regionalismos (alguns dos quais continuavam a fazê-lo ainda no final do século XX) ou a expansão dos colonizadores americanos, que exterminaram as comunidades indígenas. Esta semelhança, contudo, é ainda agravada pela herança do tráfico de escravos e pelo colonialismo imperialista, pois, segundo o líder nacionalista africano Amilcar Cabral, "o colonialismo pode ser designado como a paralisação ou a distorção, ou mesmo como o termo da história de um povo, e fator da aceleração do desenvolvimento histórico de outros povos".

O brevíssimo período que se seguiu à Segunda Guerra Mundial caracterizou-se, em primeiro lugar, por uma descolonização peculiar e tardia. A peculiaridade reside no fato da emancipação haver transcorrido largamente administrada pelas metrópoles européias, apesar da eclosão de alguns conflitos graves. Além disso, criaram-se mecanismos internacionais destinados a perpetuar essa situação, como as “ajudas" das ex-metrópoles.

Em meio a uma extrema fragilidade, iniciou-se o processo de construção do Estado-nação, como foi referido. Contudo, é necessário frisar que esse movimento histórico foi distorcido pela permanência das estruturas coloniais, através do neocolonialismo e, geralmente, da implantação de Estados inviáveis política e economicamente. Por outro lado, é forçoso reconhecer que se trata de um processo recente, de apenas algumas décadas, as quais equivalem à vida de uma pessoa de meia-idade. Ou seja, encontra-se ainda em suas fases iniciais. A retomada da História da África pelos africanos recém atravessa uma etapa comparável à Europa dos séculos XVI e XVII, ou às Américas do século XIX, mas em um mundo com os problemas ainda mais complexos do final do século XX e início do XXI.

\section{Referência}

VISENTINI, Paulo; RIBEIRO, Luiz Dario; PEREIRA, Analúcia Danilevicz. Breve história da África. Porto Alegre: Leitura XXI, 2007. 


\section{APARTHEID: APOGEU E CRISE DO REGIME \\ RACISTA NA ÁFRICA DO SUL (1948-1994)}

\section{Analúcia Danilevicz Pereira}

A África do Sul apresenta uma das evoluções mais singulares da História Contemporânea. Nessa sociedade, uma espécie de "colonialismo interno" criou um sistema de opressão institucionalizada contra a maioria negra e, em menor medida, mestiça e asiática que foi tolerada pelo Ocidente durante a Guerra Fria. Curiosamente, o fim da bipolaridade seria o ponto culminante da crise do Apartheid, abrindo espaço para uma transição negociada, embora extremamente difícil, rumo à democracia.

O governo do African National Congress, encabeçado por Nelson Mandela, acabou com a segregação jurídico-política e reinseriu o país no contexto das Nações. No entanto, a estrutura socioeconômica, com suas formas particulares de marginalização, bem como os interesses internacionais a ela vinculados têm se mostrado muito difícil de alterar. Contudo, é inegável a construção de um novo cenário sociopolítico, com uma multiplicidade de atores e a participação da maioria da população, outrora não-cidadã, mas também a geração de novas contradições. Esse país, que contrasta o convívio da modernidade com o subdesenvolvimento, ainda se encontra em transição em busca de um novo modelo societário.

\section{O Estabelecimento do Apartheid \\ e o Desenvolvimento Econômico}

$\mathrm{Na}$ formulação de seus intelectuais e na exploração dos políticos, a história do Apartheid tem início pouco antes de 1948. No en- 
tanto, a da segregação antecede essa data em muito, e não são poucos os analistas que localizam suas raízes no século XIX. A ideologia da superioridade branca e da discriminação racial era uma exigência do sistema de exploração agrária a que se dedicavam os afrikaaners, pois praticavam uma agricultura atrasada e pouco lucrativa em comparação com a cultura extensiva que a burguesia inglesa desenvolvia nas províncias do Cabo e de Natal. O pragmatismo mercantil dos britânicos considerava a escravidão como um obstáculo à formação de um mercado consumidor, mas não deixava de estabelecer barreiras rígidas para a ascensão social e econômica dos negros.

Ao iniciar a exploração das minas de ouro e diamantes, os grandes capitalistas europeus tiveram que recorrer aos operários brancos com alguma especialização e preparo intelectual. Essas pessoas, na maioria ex-fazendeiros böers que haviam perdido todo o seu capital na guerra de 1899-1902 e também europeus atraídos pela corrida do ouro, faziam exigências e reivindicações trabalhistas, pois conheciam o funcionamento do capitalismo industrial britânico. Os ingleses manipularam habilmente essa situação, prometendo vantagens aos trabalhadores brancos desde que se tornassem cúmplices na exploração de mão-de-obra negra.

Com a aprovação da Constituição da União Sul-Africana (federação das províncias do Cabo, Natal, Orange e Transvaal), a população negra foi privada do direito ao voto e à propriedade da terra. A partir de 1910, quando o país tornou-se independente da Coroa britânica, juntamente com a Austrália e o Canadá, várias leis segregacionistas foram implementadas. Entre elas, o Native Labour Act, de 1913, estendeu aos trabalhadores urbanos o sistema de submissão vigente nas fazendas, dividindo a África do Sul em duas partes: 7\% do território nacional foram deixados aos negros, os quais representavam 75\% da população (bantustões), e 93\% das melhores terras foram entregues aos brancos, que correspondiam a $10 \%$ da população.

Nas reservas negras, predominava a agricultura de subsistência e, nas demais áreas, a exploração capitalista intensiva da terra. 
Nessa lógica, o segundo setor passou a viver à custa do primeiro, que era visto como uma reserva permanente de mão-de-obra. Em 1923, o Native Urban Act limitou drasticamente a possibilidade dos negros se instalarem em cidades consideradas redutos dos brancos. Trabalhadores negros passaram a ser considerados assalariados, e seus movimentos ficaram sujeitos ao controle total através de medidas policiais e proibição de casamentos, entre outros impedimentos. E ainda, o Native Affairs Act coroou o complexo estabelecimento de uma legislação segregacionista, regulando o sistema de exploração do trabalho negro.

Esses nacionalistas, vencedores nas eleições de 1924, juntamente com seus aliados do Partido Trabalhista, representante da burguesia nacional urbana, promoveram o rompimento com a política liberal implementada pelos defensores dos grandes monopólios mineiros e impuseram medidas protecionistas. O objetivo era o de tentar neutralizar a evasão dos lucros das companhias mineiras sediadas no exterior e utilizar os recursos da agricultura branca para iniciar um processo de industrialização interna, capaz de satisfazer os interesses dos trabalhadores de origem européia.

O surgimento de um capitalismo de Estado promovido pelos nacionalistas permitiu ao país um rápido crescimento. Foram criadas siderurgias, estradas de ferro e centrais elétricas, em um momento, classificado por muitos como "milagre econômico". Entretanto, ao final da década de 1920, uma nova crise foi anunciada com a queda do preço do ouro no mercado internacional, colocando em risco também a aliança entre nacionalistas e trabalhistas. A direita nacionalista, para sobreviver no poder, abandonou a aliança com o Partido Trabalhista e apoiou-se no, outrora rechaçado, capital estrangeiro. Nessa direção, os afrikaaners continuavam controlando o poder e mantinham o sistema de segregação racial. A reconciliação com a elite próbritânica, embora permitisse a ampliação dos lucros "estrangeiros", garantiu a organização interna em relação ao sistema segregacionista. Todavia, o novo surto industrial, que resultou no aumento do nú- 
mero de negros empregados no setor, reabriu o debate entre nacionalistas ${ }^{1}$ e pró-britânicos.

De qualquer forma, foi a partir de 1948 que, efetivamente, o Apartheid foi implantado, e a fusão estabelecida em 1934 pelo Partido Unido - reunindo o Partido Nacional e o Partido Sul-Africano (o qual conta com o apoio da população de origem inglesa e de uma parcela menos significativa dos afrikaaners) - chegou a seu fim. Com os nacionalistas novamente no poder de forma "independente", a União Sul-Africana entrou em uma fase muito mais complexa, quando foram produzidas mudanças políticas, econômicas e sociais que forjaram um país, de certa forma, na "contramão da História". O que caracterizou o novo período foi a dissociação entre poder político e poder econômico; a população de origem inglesa manteve o poder econômico, enquanto os afrikaaners passaram a deter o poder político. Assim, a institucionalização do Apartheid tornou-se um dos pilares do novo surto de desenvolvimento.

A percepção do novo governo em relação à política externa do país, diante da sua posição geoestratégica e da extensão da Guerra Fria para cenários secundários, foi a de identificar-se como um "país europeu estabelecido na África”. É preciso levar em conta que a elite branca mantinha vínculos tradicionais com a Europa Ocidental e, posteriormente, com os Estados Unidos. Geograficamente, o país encontra-se na confluência de rotas marítimas e possui, em seu subsolo, riquezas minerais importantes para o desenvolvimento econômico moderno que o Ocidente necessitava e que fazia da União um bastião do chamado "mundo livre".

A União Sul-Africana explorou essa circunstância com propósitos de ordem política, econômica e de segurança. Internamente,

\footnotetext{
${ }^{1}$ Ao discurso nacionalista afrikaaner somaram-se elementos fascistas manifestos, por exemplo, na sociedade secreta Afrikaaner Bond (Irmandade Afrikaaner). A recessão no pós-Segunda Guerra Mundial repetiu o fenômeno, quando os brancos pobres, ameaçados pelo desemprego, elevaram seu racismo com o slogan "Gevaar Kaffer, Koelie, Komunismus" (Cuidado com os negros, com os índios e com o comunismo).
} 
os nacionalistas tinham como objetivo a conquista total do poder, com a consolidação da independência do país e a substituição da anglofilia predominante por uma cultura que promovesse os valores afrikaaners. No plano econômico, esforçaram-se em promover e introduzir o capital afrikaaner no coração da economia - o setor de mineração - ainda reduto do capital de origem inglesa e dos investidores externos. O Estado passou a ter expressiva participação na economia, permitindo a expansão da indústria de substituição de importações nos setores siderúrgico, químico, de minerais processados, energético e, mais tarde, de armamentos.

\section{A Intensificação do Apartheid: \\ a Reestruturação dos Bantustões}

Apesar da condenação de muitos países ao regime racista sulafricano junto à ONU, com a ascensão de Hendrik Frensch Verwoerd ao cargo de Primeiro-Ministro (1958-1966), articulador da teoria do desenvolvimento separado, o Apartheid ganhou novas características. Em 1959, ao propor a Lei de Promoção do Autogoverno Banto, Verwoerd leva o Apartheid às últimas conseqüências lógicas. $\mathrm{O}$ objetivo era o de transformar as antigas reservas negras, organizadas por tribos e de acordo com as tradições de chefia, em Autoridades Territoriais, os chamados bantustões. ${ }^{2}$

Trata-se do estabelecimento de autogoverno (autonomia administrativa), sob a égide de Pretória, portanto, sem possibilidade de autonomia política. Ao argumentar em torno do projeto de lei no Parlamento, o Primeiro-Ministro defendeu a constituição de uma comunidade de nações (uma branca e oito bantos), às quais se juntariam os protetorados britânicos, cuja independência também passou a defender.

\footnotetext{
${ }^{2} \mathrm{O}$ termo bantustão nunca foi oficial e era geralmente cunhado pelos inimigos do regime para ridicularizá-lo. Banto é o nome de um grande grupo de povos africanos e stão é uma terminação de origem persa que designa território determinado de um povo.
} 
Com o objetivo de esvaziar as pressões por um governo de maioria na União Sul-Africana, os bantustões foram uma espécie de "evolução" do Apartheid. Condenado pela ONU em 1971, o sistema foi acusado de "dividir os africanos, confrontando uma tribo com outra, enfraquecer a frente africana na sua luta pelos justos e inalienáveis direitos e consolidar e perpetuar o domínio por parte da minoria branca" (Pereira, 1986, p. 36). Quatro bantustões tornaram-se independentes e os demais optaram apenas por autonomia. Esses "Estados independentes" organizaram-se politicamente de acordo com uma constituição concebida pelo governo sul-africano e que, posteriormente, foi aprovada pela República nascente. Na verdade, esses pseudo-Estados de base tribal foram criados pelo regime para manter os negros fora dos bairros e das terras brancas, mas sistematicamente perto delas para servirem de mão-de-obra barata.

O conceito em torno dos bantustões corresponde aos primeiros anos do Apartheid, mas só nos anos 1970 a "independência" foi concedida pelo governo sul-africano e a organização das regiões redimensionada. O bantustão Bophuthatswana abrigava o grupo étnico Tswana. Com uma área de $40.000 \mathrm{~km}^{2}$, estava distribuído em sete enclaves separados nas antigas províncias do Transvaal, Cabo e Estado Livre de Orange. Em 1971, o governo concedeu autodeterminação, e em 5 de dezembro de 1977 a independência, ficando seus habitantes privados da nacionalidade sul-africana. Em Transkei, reunia-se o grupo étnico Xhosa. Localizado a nordeste da província do Cabo, com um pequeno enclave no KwaZulu-Natal, esse bantustão tornou-se independente em 26 de outubro de 1976. Essa era a região de origem de Nelson Mandela, mas tornou-se famosa pelo seu líder, Kaiser Matanzima.

Outro bantustão que reuniu a etnia Xhosa foi o de Ciskei. Independente em 4 de dezembro de 1981, possuía uma área de $7.700 \mathrm{~km}^{2}$ em duas áreas separadas - uma na parte oriental da antiga província do Cabo e uma pequena porção de costa no Oceano Índico. Em 1961, esse território passou a ser uma região administrativa separada e, em 1972, o governo sul-africano concedeu-lhe autodeterminação. Em 13 
de setembro de 1979, Venda tornou-se independente. Localizado a nordeste da antiga província do Transvaal, atual província de Limpopo, esse bantustão que abrigava o grupo étnico Venda recebeu autodeterminação em 1973 e posterior independência.

Os bantustões Gazankulu, Kangwane, Kwandebele, KwaZulu, Lebowa e QwaQwa nunca se tornaram independentes. Gazankulu, de etnia tsonga, localizava-se a nordeste da antiga província do Transvaal. Em 1971, o governo sul-africano concedeu-lhe autodeterminação. KaNgwane, também localizado a nordeste da antiga província do Transvaal, atual província de Mpumalanga, reunia o grupo étnico Swazi. Em 1981, o governo atribuiu-lhe autodeterminação com o objetivo de formar uma zonatampão contra a infiltração de guerrilheiros do ANC. Ainda em 1981, foi criado Kwandebele, de etnia ndebele, na atual província de Mpumalanga. Criado na antiga província do Natal, atual KwaZulu-Natal, o Kwazulu tem suas raízes na reserva para nativos zulus, estabelecida pelos britânicos na colônia do Natal, ainda no século XIX.

Mais tarde, o governo do Partido Nacional organizou territórios separados para brancos, negros e mestiços. Em 1959, foram nomeadas autoridades tribais e regionais para o Kwazulu e, em 1972, o bantustão recebeu autonomia, com a autoridade territorial transformada em uma "assembléia legislativa”, sendo Mangosuthu Buthelezi, antigo chefe tribal, nomeado ministro-chefe. Esse território era relativamente extenso (ocupando cerca da metade da então província de Natal), mas formado por um grande número de entidades separadas, incluindo uma na costa, junto à fronteira com Moçambique. Os zulus são em cerca de 7 milhões, a maioria vivendo no Kwazulu-Natal. Por fim, Lebowa, localizado a nordeste da antiga província do Transvaal, atualmente nas províncias de Mpumalanga e Limpopo, e QwaQwa, localizado na província do Estado Livre, junto a Lesotho, reuniam os grupos étnicos Sotho do Norte ou Pedi e Sotho do Sul, respectivamente.

Diante de um intenso movimento de descolonização, o governo sul-africano encontrou na particularidade de um "colonialismo interno" a solução para a consolidação de um longo processo de for- 
mação e desenvolvimento do sistema capitalista local. Por outro lado, na solução neocolonial clássica, "o Estado colonizador se retira do território até então colonizado e a administração do novo Estado passa, no caso, a ser assumida por uma nova e dominante elite local, mantendo, porém, o antigo Estado e classe colonizadora suas anteriores e estratégicas posições econômicas” (Pereira, 1986, p. 32).

No caso sul-africano, sabe-se, a classe ou nação colonizadora não pode retirar-se a um Estado de origem, e essa especificidade não impediu que fosse encontrada uma saída igualmente particular e original para o neocolonialismo. $\mathrm{O}$ fracionamento da população negra produziu um formidável contingente de mão-de-obra disponível e barata, com que a indústria e a agricultura das áreas brancas se abasteciam livremente. E ainda, com o desenvolvimento desses bantustões e dos Estados independentes, surgiu uma classe negra dirigente que, embora dependente, assumiu as responsabilidades administrativas e parte das atividades econômicas, particularmente comerciais. Essa nova classe, integrada por africanos, chamada a cooperar nesse esforço de racionalização das formas tradicionais de dominação econômica, social e racial, beneficiou-se da proposta neocolonial e aderiu, com sua enorme carga de contradições, aos propósitos de minar o processo e as lutas de libertação nacional. Essa pequena elite, beneficiada à margem do Apartheid, tentou cumprir seu papel de reduzir os anseios em torno da libertação nacional e restringi-los a reivindicações locais baseadas em um fracionado nacionalismo tribal.

\section{A Luta Antiapartheid}

A estruturação do sistema do Apartheid foi acompanhada pela luta anti-racista. Em 1912, foi fundado o African National Congress (ANC), primeira organização política dos negros sul-africanos. Seus criadores, egressos das escolas mantidas por missionários europeus, muitos deles com estudos e títulos obtidos em universidades americanas e européias, estabeleceram um programa inicialmente conciliador. Os primeiros líderes do ANC acreditavam que poderiam dis- 
cutir com os afrikaaners o conteúdo injusto das leis de segregação racial e pensavam também convencer os liberais britânicos a admitir a co-participação dos negros nas questões políticas. Logo, a perspectiva inicialmente perseguida pelos líderes do ANC seria posta à prova diante da greve de 40 mil mineiros negros em $1920 .^{3}$

Na década de 1940, o ANC adotou uma estratégia de resistência não-violenta em relação às leis segregacionistas e, em 1955, conseguiu ampliar a frente anti-racista através da chamada Freedom Charter (Carta da Liberdade), subscrita também pelos movimentos de indianos, de mulatos, de liberais e de socialistas. A Carta apresentava uma denúncia radical do Apartheid e discutia sua abolição, bem como defendia a redistribuição da riqueza. Durante a Segunda Guerra Mundial, foram intensas as atividades de mobilização social, quando se verificaram mais de 300 greves envolvendo 58.000 trabalhadores negros e 60.000 brancos, representando uma alteração do sistema político imposto pelos afrikaaners.

Essas greves provocaram o surgimento, dentro do ANC, de um setor mais radical liderado por Nelson Mandela e Oliver Tambo, os quais assumiram, lentamente, posições de comando dentro da organização. Em 1958, setores do ANC que discordavam da política multirracial do movimento criaram o Pan-Africanist Congress (PAC), o qual, em 1960, convocou uma manifestação na cidade de Sharpeville para protestar contra a lei que limitava o movimento dos trabalhadores negros em áreas reservadas aos trabalhadores brancos. A repressão foi intensa e, em seguida, PAC, ANC e Partido Comunista foram postos na ilegalidade.

A luta anti-racista, que originalmente propunha-se conciliadora, sofreu uma mudança radical após esses episódios. O ANC formou um braço armado, o mK (Umkhonto we Sizwe), e o PAC organizou

\footnotetext{
${ }^{3}$ Em torno de 1920 foi fundado o Sindicato de Comércio e Indústria (ICU), que reunia os trabalhadores negros e, em 1921, foi fundado o Partido Comunista Sul-Africano, em sua maioria, integrado por brancos.
} 
o Poqo, quando, em 1963, Nelson Mandela foi preso e condenado à prisão perpétua, enquanto Oliver Tambo foi compelido a assumir o comando do movimento no exílio. A repressão governamental e a falta de apoio dos países vizinhos - dominados por regimes aliados dos afrikaaners -impediram a ampliação da guerrilha e o recrutamento das grandes massas. A vitalidade do sistema do Apartheid se deveu, em boa medida, ao interesse do capital internacional em investir na região, atraído pelo grande mercado de mão-de-obra barata. As inversões estrangeiras, especialmente as norte-americanas, quintuplicaram seu valor entre 1957 e 1958.

A política protecionista dos afrikaaners criou a infra-estrutura necessária para o estabelecimento de grandes indústrias, culminando com o desenvolvimento de um pólo industrial capaz de abastecer toda a África Austral. Acompanhando esse processo, deve-se destacar o gradativo aumento de trabalhadores rurais negros que chegavam às cidades. A miséria dos bantustões e a ausência de serviços e assistência de todo o tipo provocaram o êxodo massivo que afetaria significativamente o interesse de outros grupos sociais, como os mulatos, que pretendiam se integrar à economia branca. Em 1976, outro episódio de contestação resultou no massacre de 600 manifestantes negros em Soweto (South West Township), no subúrbio de Johannesburgo. Os acontecimentos de Soweto colocaram o problema da condição dos negros diante dos olhos da minoria branca - a crise havia chegado às suas cidades.

\section{A Crise Econômica \\ e o Esvaziamento do Apartheid}

A política econômica adotada pelo Partido Nacional, a industrialização por substituição de importações (sustentada pelo excedente da exploração do ouro) fizeram da África do Sul um dos dez países mais ricos do mundo, segundo o Fundo Monetário Internacional. Foram criadas tarifas protecionistas na tentativa de desenvolver um 
setor industrial local e, quando as sanções internacionais começaram a causar problemas, o governo sul-africano buscou alcançar a autosuficiência no maior número de áreas possível. Como resultado desse esforço, a indústria tornou-se o setor mais importante da economia sul-africana nos anos 1960, e sua contribuição para o PIB era maior que o da mineração e da agricultura juntas.

Todavia, o setor industrial orientava-se em direção ao segmento do mercado interno de maior renda, e para a produção de bens "estratégicos", tais como armas e combustíveis (Davies, 1996, p. 564). Embora o objetivo do programa dos nacionalistas fosse o de atingir os níveis máximos de auto-suficiência, o setor industrial continuava altamente dependente da importação de bens de capital, financiados pela moeda estrangeira obtida com a exportação de produtos primários. Dessa forma, mesmo diante do isolamento político, a economia sul-africana nunca esteve completamente desligada do resto do mundo. A participação no comércio internacional era a origem de pelo menos 50\% do PIB durante todo esse período (Butler, 2004, p. 152).

Os últimos anos do sistema do Apartheid viram esse modelo de acumulação afundar-se em uma crise cada vez mais grave, fortemente vinculada à crise social e política do próprio Apartheid. Vários foram os elementos do complexo esvaziamento do sistema, mas, sem dúvida, o isolamento econômico do período Botha foi o mais importante.

Após o surto de expansão dos anos 1960, a economia sul-africana ingressou em uma crise estrutural entre os anos 1970 e 1980 . O crescimento do PIB caiu para uma média de 3,3\% e, além disso, ele se tornou volátil. A taxa de crescimento da demanda interna declinou de 6,9\% para 3,6\% ao ano nesse período. Todos os componentes da demanda, tais como consumo público, privado e investimentos, apresentaram uma rápida desaceleração. A contribuição do comércio internacional para o crescimento tornou-se negativa, com as importações crescendo mais rapidamente que as exportações, o que veio a se constituir no principal fator dos problemas de balança de pagamentos (Le Pere apud Gelb, 1991, p. 25). 
O aumento dos preços do petróleo causado pela crise de 1973 não afetou significativamente a África do Sul. O impacto negativo dessa crise foi compensado pelo aumento dos preços dos produtos primários para a exportação. Esse aumento afetou principalmente o preço do ouro, que subiu de forma rápida a partir de 1973, quando o padrão-ouro foi definitivamente abandonado. Por outro lado, o desempenho das exportações de produtos industrializados deteriorouse, fato que muitos analistas atribuem à falta de competitividade dos produtos sul-africanos.

Após o Levante de Soweto, em 1976, houve também um declínio nos índices de investimentos. Segundo Garth L. Le Pere (2006, p. 282), a queda dos investimentos privados pode ser explicada em relação a três fatores interligados: a perda de confiança dos setores privados na evolução da economia no contexto de um ambiente político profundamente convulsionado e instável; as limitações impostas pelas perspectivas cada vez mais sombrias para os investimentos em produtos substitutivos; e, por fim, a inexistência de saídas exportadoras satisfatórias. As empresas públicas enfrentaram situação semelhante. $\mathrm{O}$ aumento do custo do crédito, de 1980 em diante, associado ao aumento das taxas de juros internacionais e, posteriormente, às políticas deflacionárias implementadas após 1985, a fim de garantir o equilíbrio da balança de pagamentos, agravaram ainda mais o problema. E ainda, as crescentes dificuldades orçamentárias, principalmente pelo aumento dos gastos com segurança, completam o quadro de crise econômica.

Dessa forma, durante a década de 1980, três acontecimentos provocaram a recessão da economia, anunciando o fim do Apartheid. Em primeiro lugar, a queda dos preços do ouro, que começou em 1981, reduziu as receitas cambiais e prejudicou a lucratividade das minas de ouro. O preço do ouro declinou de maneira constante entre 1981 e 1985. Essa queda, que afetou também outras matérias-primas, levou a um declínio das exportações e a uma desvalorização do rand sul-africano, ao mesmo tempo em que causava também reduções drásticas nos ingressos orçamentários. 
Em segundo lugar, na medida em que a queda dos preços das matérias-primas provocava impactos graves nas receitas fiscais, as despesas orçamentárias necessárias para manter em funcionamento a máquina do Apartheid ${ }^{4}$ e assegurar a sobrevivência do regime tornavam-se exorbitantes. Agravando ainda mais esse quadro, o isolamento cada vez maior do país, não apenas em nível internacional, mas fundamentalmente em termos regionais após a independência de Angola, de Moçambique e do Zimbábue, além das despesas militares e das despesas com a manutenção do aparato estatal de segurança, tornaria o sistema insustentável.

Por fim, devem-se considerar as sanções financeiras impostas à África do Sul. A crise da dívida de 1985, como destacado anteriormente, levou a uma retirada de crédito generalizada. Pouco depois, o país foi obrigado a declarar moratória de seu serviço de dívida. Em 1989, a recessão estava instalada, só vindo a ter fim em 1993.

$\mathrm{O}$ alto custo em manter o isolamento econômico em um mundo que se globalizava levou a África do Sul a mudar de rumo. No final dos anos 1980, o regime do Apartheid havia transformado o país em um campo de batalha - envolvido em uma guerra convencional em Angola e em processos menos evidentes de desestabilização em vários outros países, sem falar na instabilidade interna -, não conseguindo, portanto, cumprir com seus objetivos iniciais. $\mathrm{O}$ apoio dos tradicionais parceiros econômicos não resistiu diante da crise, e as condenações ao regime se intensificaram.

As investidas regionais sul-africanas não intimidaram os Estados vizinhos, tampouco conseguiram forçá-los à submissão que bloquearia a luta pela liberdade, ainda que as tentativas de desestabilização tivessem deixado um rastro de destruição econômica e de insegurança humana. Internamente, a resistência tendeu a fortalecer-se

\footnotetext{
${ }^{4}$ Os custos políticos do Apartheid ligavam-se também à tarefa de deslocar milhões de pessoas negras para as terras natais de sua etnia e aos investimentos em construção correspondentes, bem como às medidas fiscais destinadas a atrair investimentos para criar empregos e fixar essas populações nessas terras.
} 
diante da radicalização da crise econômica e política. A desigualdade socioeconômica de inspiração racial entre os diferentes grupos da África do Sul, bem como o enorme contingente de refugiados tornaram-se problemas que o país e a região teriam que solucionar.

A crise econômica afetou profundamente a imagem de "credibilidade" do governo sul-africano. A partir de meados dos anos 1980, cresceu o número de países que passaram a acatar a proposta de sanções econômicas (entre eles, nove dos dez integrantes da CEE e os Estados Unidos). Entre 1984 e 1988, embora o governo procurasse aparentar, em particular aos investidores e clientes da África do Sul, que a opressão racial estava terminando, a elite afrikaaner abandonou a visão reformista para resgatar uma política tradicional, decretando medidas de exceção em todo o país, e retomando a violência interna como meta principal.

Apesar das ações repressivas, novas frentes de oposição foram criadas, como a United Democratic Front (UDF), a Azanian People's Organization (Azapo) e o Congress of South African Trade Union (Cosatu). Em abril de 1985, foram revogadas as leis que proibiam casamento e relações sexuais entre pessoas de diferentes raças. No mês seguinte, caiu a proibição de pessoas de raças diferentes pertencerem ao mesmo partido. Em abril de 1986, o governo promulgou leis que eliminavam restrições ao movimento, residência e emprego de negros em áreas brancas. Em julho de 1986, as leis de passaporte foram revogadas, criando-se um mesmo documento de identidade para todos os cidadãos sul-africanos.

Apesar das aparências, Botha não estava acabando com o regime, mas, sim, alterando suas formas - concessões políticas aos colored e hindus e concessões econômicas aos negros deveriam dar um novo fôlego ao monopólio branco de poder. Na realidade, nos últimos anos do Apartheid, já era visível a rápida incorporação dos negros à economia industrial. Segundo Paul Singer (2000), em 1960 os africanos constituíam 23\% dos profissionais e técnicos, 9\% dos gerentes e administradores, $6 \%$ dos empregados de escritórios e 18\% do pessoal de vendas. 
Já em 1980, essas percentagens eram de 31\%, 4\%, 25\% e 40\%, respectivamente. Exceto os cargos de gerentes e administradores, a participação africana nas ocupações mais qualificadas aumentou substancialmente, o que refletiu na distribuição de renda.

A estratégia do governo Botha falhou - a nascente classe média negra, em sua grande maioria, rejeitou o esquema de cooptação, bem como os demais grupos étnicos. A UDF ampliou-se a tal ponto que chegou a agregar 700 organizações, representando 2.000 .000 de pessoas. Logo, as palavras de ordem dos anos 1950 e 1960 foram retomadas, apoiadas pelo sindicalismo africano em ascensão. Esse movimento retomou a Carta da Liberdade de 1955 e, inevitavelmente, trouxe de volta o ANC ao centro da arena, apesar das restrições legais.

Os setores negros em ascensão não aceitaram o novo lugar subordinado que as reformas de Botha passaram a lhes oferecer, e aqueles que aceitaram os papéis de "governantes" tornaram-se alvo da revolta que a massa dos cortiços e das favelas promoveu. Essa situação decorreu do decreto governamental que estabelecia que os distritos negros deveriam se autogovernar mediante a eleição de conselhos. A não-aceitação desse processo e o baixo índice de eleitores que compareciam às urnas permitiram que esses vereadores trabalhassem em causa própria, o que conduziu a um notável esquema de corrupção.

Em torno de 1984, as novas municipalidades representavam focos de profunda tensão social. Os enfrentamentos entre manifestantes e a polícia passaram a ser uma constante. O que ocorreu na África do Sul entre 1984 e 1987 pode ser comparado aos episódios de Sharpeville, em 1960, e Soweto, em 1976. No entanto, a extensão e a duração dos enfrentamentos tenderam a crescer e se intensificar, e o efeito político foi decisivo diante da crise do Apartheid.

As reformas de Botha, se, por um lado, tinham como objetivo reorganizar o regime internamente, por outro, buscavam melhorar a imagem externa do país perante as principais potências capitalistas Estados Unidos, de Reagan, Grã-Bretanha, de Thatcher, e Alemanha, de Kohl. Os governos conservadores desses países eram sensíveis aos 
esforços do governo sul-africano no sentido de descaracterizar o regime nas suas facetas mais condenáveis. A convergência de interesses entre esses países e a África do Sul, principalmente os de caráter estratégico, pode ser diagnosticada na posição de Thatcher ao sugerir à comunidade internacional que diminuísse algumas das medidas restritivas como forma de encorajar a África do Sul a continuar suas reformas (Fieldhouse, 2005, p. 445). À crise do regime, paralelamente às contradições sociais internas e às pressões regionais e internacionais, agregou-se outro componente crucial - as cisões no seio do Partido Nacional.

As concessões feitas aos grupos não-brancos foram rejeitadas pela ala mais radical do Partido Nacional, que acabou rompendo com o mesmo e fundando o Partido Conservador, enquanto outro grupo estava convencido de que seria necessário estabelecer um diálogo com a maioria da população do país, ainda que as suas demandas exigissem novas considerações. O Partido Nacional, portanto, dividiu-se em duas correntes que, em verdade, permearam a opinião do próprio afrikanerdom (comunidade afrikaaner).

No final da década de 1980, a mudança processada no cenário internacional refletiu significativamente sobre a política interna e externa da África do Sul. Diante de um novo jogo de forças que se constituía, as sanções econômicas se intensificaram, e as críticas morais em defesa dos direitos humanos tornaram-se bandeiras em todas as partes do mundo. O boicote global à África do Sul produziu fortes constrangimentos econômicos internos e refletiu de forma significativa sobre a política regional. As mudanças mais visíveis na política regional foram as negociações bem-sucedidas em torno da independência da Namíbia e da retirada das tropas cubanas de Angola.

$\mathrm{Na}$ verdade, diante do enfraquecimento militar, da nova détente entre as duas superpotências e da necessidade de apresentar uma postura diferenciada para a comunidade internacional no intuito de evitar sanções mais duras, a África do Sul optou por trocar a independência da Namíbia pela retirada das tropas cubanas de Angola. Através de um 
grande esforço diplomático, os sul-africanos buscaram resolver os conflitos regionais sem serem desmoralizados. Para tanto, tiveram que permitir que os cubanos celebrassem seu engajamento militar como fator decisivo na derrota do regime do Apartheid em Angola.

\section{Considerações Finais: a Recomposição das Forças Políticas e a Transição Democrática}

As condições objetivas para uma mudança significativa na postura do Partido Nacional estavam postas. A situação econômica e o esgotamento das estratégias políticas militarizadas não davam mais suporte à manutenção do regime. Botha colocava-se como um obstáculo a um avanço qualitativo nas negociações com as lideranças do ANC. Diante da fragilidade de sua saúde e dos apelos de seus próprios ministros, o presidente apresentou sua renúncia, cedendo o lugar ao então presidente do Partido Nacional e ministro da Educação, Frederik W. De Klerk, em agosto de 1989. Nas eleições que se seguiram, o Partido Nacional fez uma campanha bastante conservadora, sem indicar qualquer possibilidade de mudança. No entanto, o próprio De Klerk justificou que essa posição foi tomada em função do temor em perder os votos dos conservadores. Embora alguns observadores identifiquem o ponto de virada da política sul-africana com a gestão De Klerk, o início dessas mudanças ligeiramente antecede sua posse.

De qualquer forma, a abertura de uma nova fase foi marcada pelo memorável discurso no Parlamento, em 2 de fevereiro de 1990, no qual o presidente De Klerk anunciou a legalização de todos os partidos banidos - o ANC, a Umkhonto we Sizwe, o PAC, a UDF e o Partido Comunista Sul-Africano -, a libertação de Nelson Mandela e de centenas de outros prisioneiros políticos. Afirmou também sua prontidão em negociar com todos os "novos" atores uma Constituição nacional e a revogação de medidas repressivas que restringiam a liberdade de impren- 
sa e os direitos dos presos políticos. Em menos de dois anos, a liderança de De Klerk permitiu que fosse suspenso o Estado de exceção em todo o país; libertada a grande maioria dos presos políticos; legalizadas as oposições extraparlamentares; promovida a repatriação dos exilados; promulgada a revogação do Reservation of Separate Amenities Acts do Group Areas Act, dos Land Acts e do Population Registration Act e abolidos os estatutos dos bantustões. Essas medidas possibilitaram um jogo cooperativo entre o governo e as forças de oposição.

Diante da nova conjuntura, Pretória encaminhou um processo de distensão, tanto no plano interno como externo. No plano externo, dentro da nova postura que desenhava uma estratégia cooperativa, a administração De Klerk obteve a recuperação da credibilidade internacional do governo e a recomposição das relações externas do país. No entanto, no âmbito interno, as negociações não foram tão simples. Em dezembro de 1991, realizou-se a importante Convention for a Democratic South Africa (CODESA) no World Trade Center, perto de Johannesburgo. A Convenção teve continuidade como a CODESA II, e subseqüentemente como um Conselho de Negociação (Negotiating Council). Mais de 200 delegados de 19 partidos políticos participaram das discussões, exceto alguns partidos direitistas e o Inkatha Freedom Party (IFP). Como centro do debate, uma nova constituição foi acordada: a lei da maioria se tornou um fato.

No início de 1992, o Partido Nacional sofreu uma dura derrota nas eleições em Potchefstroom. Desse modo, De Klerk decidiu chamar um referendo para estabelecer se os sul-africanos brancos queriam continuar na rota das negociações. O referendo realizouse em 17 de março de 1992. No mês de junho, houve o então chamado "Boipatong massacre", quando Armed I.F.P Supporters atacaram a região. Mais de 40 pessoas foram mortas. Em agosto, houve uma greve em peso e, em setembro, milhares de apoiadores do ANC marcharam para Bisho, na então terra dos negros Ciskei. Soldados indisciplinados abriram fogo quando a marcha saiu do controle. Quase 30 pessoas foram mortas. Em abril de 1993, houve um 
evento com potencial de inflamar o país. Chris Hani, o respeitadíssimo secretário-geral do Partido Comunista e um membro da milícia $\mathrm{mK}$ foram assassinados perto de Johannesburgo. Os assassinos logo foram presos, e Mandela, habilmente, usou o fato de que tinha sido uma mulher afrikaanner, Retha Harmse, que denunciara o crime à polícia. Em junho de 1993, foi decidido que as eleições ocorreriam em 27 de abril de 1994, terminando com o domínio da minoria branca. O IFP ainda boicotava as negociações, mas os outros partidos partiram para a campanha. Em setembro, os partidos concordaram que um Transitional Executive Council iria ser formado para pavimentar o caminho em direção às eleições.

\section{Referências}

BUTLER, Anthony. Contemporary South Africa. New York: Palgrave Macmillan, 2004.

DAVIES, Robert. Promoting regional integration in Southern Africa: an analysis of prospects and problems from a Southern African perspective. African Security Review (Johannesburg) no 5, 1996.

FIELDHOUSE, Roger. Anti-Apartheid: a history of the movement in Britain. London: The Merlin Press, 2005.

LE PERE, Garth L. A África do Sulpós-apartheid: do isolamento econômico à transformação social. In: VILLARES, Fábio (Org.). Índia, Brasil e África do Sul: perspectivas e alianças. São Paulo: UNESP/IEEI, 2006.

PEREIRA, Analúcia Danilevicz. "África do Sul e Brasil: dois caminhos para a transição ao pós-Guerra Fria” (Tese de Doutorado). Porto Alegre: PPG em História da UFRGS, 2007.

PEREIRA, Francisco José. Apartheid: o horror branco na África do Sul. São Paulo: Brasiliense, 1986.

SINGER, Paul Israel. A política econômica externa da África do Sul. In: Samuel GUIMARÃES (Org.). África do Sul: visões brasileiras. Brasília: IPRI/ FUNAG, 2000.

VISENTINI, Paulo Fagundes; RIBEIRO, Luis Dario Teixeira; PEREIRA, Analúcia Danilevicz. Breve História da Africa. Porto Alegre: Leitura XXI, 2007. 


\section{2 \\ ANGOLA: INDEPENDÊNCIA, CONFLITO E NORMALIZAÇÃO}

\section{Joveta Jose}

É talvez demasiado pretensioso e ousado escrever um texto desta natureza, Angola: Independência, Conflito e Normalização, não somente por causa da intensidade das evoluções e dos retrocessos das condições sociais e econômicas em Angola, mas também porque talvez não tenha ainda decorrido o tempo necessário para uma compreensão histórica das transformações que se operaram no país.

Para o presidente de Angola, os problemas que este país enfrenta desde a delimitação das suas fronteiras em 1885 até os dias atuais são bastante complexos. Para ele:

Muitos dos nossos problemas têm a idade de Angola e são complexos, outros, de caráter políticos, têm a idade da independência e também são complexos. Os primeiros relacionam-se com a construção da nação angolana nos limites das fronteiras definidas na conferência de Berlim em 1885 e por outros acordos entre as potências coloniais. Eles são tratados e equacionados sistematicamente com base na legislação fundamental do Estado e do princípio livre aceite, ou pelo menos consentido... Os outros são decorrentes de várias conexões que interligam pessoas e interesses angolanos e estrangeiros numa teia de esquemas, mecanismos e instrumentos em que se distinguem duas categorias: nacionalistas e agentes de neocolonialismo (Santos, 2000, p. 7).

São várias questões enfrentadas que vão desde a estabilização da economia, pacificação dos espíritos marcados por longo período de guerra civil; encontrar caminhos da democracia acompanhada de reformas sociais para diminuir o estado de pobreza que tem assolado todo o país; melhorar as más condições de habitação, sanitárias e ambientais. Dentre todas essas dificuldades, a maior delas estava em instituir um ponto final na guerra civil que durou vinte e sete anos e que reduziu a capacidade de resolução de variáveis estruturais, e o país 
seguiu sua trajetória histórica marcada por longos retrocessos e ínfimos avanços na sua afirmação como país soberano.

\section{Período Pré-Colonial \\ e a Resistência à Colonização}

Quando, em 1482, os primeiros portugueses chegaram às costas dos territórios que seriam mais tarde a pátria angolana, conduzidos por capitão Diogo Cão, já existiam formações econômico-sociais de classes fortemente organizadas, como, por exemplo, o reino do Congo com os seus principais tributários ou reinos submetidos: Loango, Kakongo, Bata, Ngoyo, Ndongo, Reino da Lunda, com os vizinhos Luba e Kazembe; a zona onde existia ainda a formação econômico-social do Comunismo Primitivo como as tribos do sul, os bosquimanos que desconheciam a agricultura e a pastorícia. O reino do Congo e o reino da Lunda foram os principais centros de formação econômico-social, dominando o modo de produção escravagista, em que o principal trabalho produtivo era feito por escravos, ao passo que os principais beneficiários desses produtos eram a aristocracia, dona dos escravos, e os chefes administrativos das províncias e dos distritos. Os principais reinos eram Ndongo, Congo, Estados livres da Kissama, Matamba e Kassanje.

A princípio, os portugueses estabeleceram relações cordiais com as autoridades locais e conseguiram, através delas, introduzir o cristianismo, chegando a alterações de nomes e localidades, como, por exemplo: Nzinga Nkuvu teve o nome alterado para D. João I; Mbenda a Nzinga - D. Afonso I; Nkanga a Mbemba - D. Pedro I; Nkudi a Mpudi - D. Diogo I; Mbemba a Nzinga - D. Afonso II; Nempazu a Nimi - D. Álvaro II, etc. Gradualmente, os portugueses foram captando as populações nativas e efetuando a ocupação do território por meio de uma colonização a princípio representada, exclusivamente, por missionários católicos e por comerciantes. 
Assim, durante pelo menos cinco dezenas de anos que durou essa fase, os portugueses mantiveram as relações pacíficas que haviam estabelecido logo no início. As investidas militares começaram com o governador Paulo Dias de Novais nos anos 1560-1574, através de uma intensa atividade que se traduziu por uma ocupação de carácter acentuadamente militar, ao mesmo tempo em que continuou a ação assimiladora pelos padres jesuítas, os quais estavam encarregados de civilizar pela cristianização dos povos nativos. Paulo Dias de Novais chegou a ser preso e feito escravo pelo rei Ngola Kiluanje no reino do Ndongo durante seis anos. Ao fim desse período, Ngola Kiluanje mandou Novais e um embaixador do rei a Portugal para solicitar ajuda de Portugal na luta contra os reinos vizinhos, assim como pretendia fazer comércio pacífico com Portugal. Em 1575, Novais chegou de novo na Baía de Luanda, construiu uma igreja e deu início à povoação de Luanda.

Os portugueses perderam uma considerável parte de Angola para os holandeses, inclusive Luanda - o porto para embarcar os escravos que iam para o Brasil. Os colonizadores portugueses lutaram de 1641 a 1648 para a recuperação de Luanda desalojando os invasores holandeses. Em socorro aos portugueses, o Brasil reuniu navios e homens em 1648 partindo de Recife rumo a Luanda, uma missão militar para libertar a província ultramarina das mãos dos holandeses. O reduto de Massagano resistiu a todos os ataques dos holandeses aos portugueses até a chegada das forças expedidas do Brasil. O domínio holandês em Angola durou oito anos. O desenvolvimento das manufaturas nas Américas levou os portugueses a implementar a compra de nativos cativos dos reis e transformá-los em escravos e a convencer as autoridades a guerrearem-se entre si para obter mais escravos destinados ao trabalho forçado nas Américas e em suas colônias de São Tomé e Brasil.

As campanhas militares deste tempo e a ocupação colonial não conseguiram acabar com a resistência progressista do povo angolano. A independência do Brasil em 1822 veio a trazer muitas complicações à política portuguesa em Angola, pois os brasileiros já pensa- 
vam em juntar Angola na Federação antes da independência, para continuar a receber escravos ou fazer de Angola um mercado para produtos brasileiros. Os ricos usineiros do Brasil naquela época não queriam que Portugal fosse intermediário da venda do açúcar em Angola, assim como estavam interessados em industrializar o Brasil à semelhança dos países da Europa. As classes ricas da colônia de Angola estavam divididas porque o capital angolano era ainda fraco comparado ao do Brasil. Alguns angolanos das classes ricas queriam que Angola fosse independente, como o Brasil; outros queriam que Angola continuasse ligada a Portugal e aqueles que economicamente estavam ligados ao Brasil queriam a independência, mas que entrasse na federação com o Brasil.

Essa animosidade provocou cada vez mais revoltas, protestos, manifestações em Luanda e Benguela ${ }^{1}$ (que eram pontos de litoral mais importantes) contra Portugal ou, então, contra o Brasil. O povo angolano não ficava quieto e calado por ter sido dominado pelos colonialistas portugueses. Todas as ocasiões eram aproveitadas para tentar a libertação. Mas as condições não estavam ainda maduras para uma revolta nacional, e a revolta mais conhecida do planalto é a de Mutu Ya Kevela em 1902, dentre as várias manifestações. É de se realçar que o avanço português foi devido à desunião que conseguiram criar entre os angolanos.

Os interesses para ocupar a África não estavam confinados apenas para os portugueses. Inglaterra, França, Alemanha, Bélgica faziam comércio com a África e aqui procuravam o ouro, marfim e escravos. Angola não era uma colônia de ocupação, mas uma praça comercial na época.

Em 1884, os países imperialistas já tinham ocupado grande parte de África, mas havia ainda áreas de conflito, principalmente as áreas sob o domínio dos portugueses. $\mathrm{O}$ aumento desses conflitos

\footnotetext{
${ }^{1}$ Luanda e Benguela passaram pela mão dos holandeses e Benguela, até pela dos franceses, em 1705.
} 
fez com que os Estados imperialistas de todo o mundo convocassem a famosa Conferência de Berlim em 1884-1885 para dividir a África entre eles. Entre os pontos importantes da conferência, definia-se que só podia ter territórios coloniais quem os ocupasse com tropas, a obrigação de respeitar os tratados de protectorados com os soberanos africanos, o fim da escravatura e a adoção de medidas de civilizar os nativos.

No entanto, só cerca de 1900 é que os portugueses conseguiram controlar toda a extensão do vasto território, que constitui hoje a República de Angola. Mas, mesmo depois de 1900, os angolanos continuaram a resistir ao domínio português.

A população de Angola, que em 1940 era de 3.738.010 habitantes, elevou-se a 4.145.184 em 1950. Esses números revelamnos que a população total sofreu um aumento de cerca de 11\% no decurso do decênio e que, individualmente, o maior crescimento correspondeu aos brancos, que representou $78,9 \% \%^{2}$, porque Portugal criou incentivos para a emigração dos portugueses para Angola. Nessa época, o sistema de ensino oficial em Angola subdividia-se em dois setores distintos: um para nativos e outro para brancos e assimilados (filhos de famílias de cor negra, mas civilizadas), mas essa distinção era apenas em função de grau de desenvolvimento mental e social.

Fundamentalmente, havia dois graus de ensino em Angola, isto é, o Primário e o Secundário. O ensino primário era rudimentar, geral e complementar, enquanto que o ensino secundário era liceal, técnico, profissional e magistério primário. O ensino primário era destinado a crianças nativas em grau atrasado de civilização, sendo exercido oficialmente pelas missões católicas portuguesas. Incluía uma classe preparatória e três classes ascendentes, cada uma correspondendo a um ano escolar. O ensino geral e elementar era destinado a

\footnotetext{
${ }^{2}$ Informações extraídas do livro organizado pela Direcção dos Serviços de Economia. Angola: Província de Portugal em África. Luanda: Gráfica de Publicações Unidade, 1953, p. 40.
} 
brancos e assimilados que compreendiam de três a quatro anos escolares e terminavam com exames na $3^{\mathrm{a}}$ e $4^{\mathrm{a}}$ classes (séries).

\section{A Luta pela Libertação Colonial}

Em 1953, nasceu o primeiro partido político nacionalista - PLUA (Partido da Luta Unida dos Africanos de Angola) -, que lançou o manifesto que convidava os angolanos a se organizarem clandestinamente. Alguns dirigentes do PLUA e de outras organizações clandestinas criaram o MPLA (Movimento Popular de Libertação de Angola), em 10 de dezembro de 1956, que possuía ampla representação em território angolano e tinha nítidas diretrizes e orientações ideológicas marxistas. Além do MPLA, surgiram outros movimentos para a independência de Angola, como o MINA (Movimento para Independência Nacional de Angola), a UPNA (União das Populações do Norte de Angola), transformado depois em UPA (União das Populações de Angola), e outras organizações regionais ou de tendências reformistas.

Algumas das organizações regionais evoluíram para forças organizadas de libertação de Angola. É o caso da FNLA (Frente Nacional para a Libertação de Angola), fundada em 1962 na região Norte, como desdobramento da UPA, e a UNITA (União Nacional para Independência Total de Angola), surgida em 1966 como uma dissidência da FNLA, liderada por Jonas Savimbi, com a FALA (Forças Armadas de Libertação de Angola) na região Sul, além do MPLA, movimento hegemônico representado proporcionalmente em todo o território angolano com a FAPLA (Forças Armadas Populares de Libertação de Angola).

Em 4 de fevereiro de 1961, foram atacadas as cadeias de Luanda com participação de jovens e trabalhadores da capital enquadrados por militantes do MPLA, para libertar os presos políticos. Assim, tem início a luta armada pela independência nacional. As riquezas naturais presentes no país, principalmente a opulência de jazidas de petróleo e diamantes, contribuíram para acirrar as disputas entre os 
movimentos pela independência, como também despertaram a cobiça e o interesse internacional no conflito angolano. Os movimentos pela libertação receberam apoios financeiros, bélicos e humanos da comunidade internacional. Assim, o MPLA, com sua orientação socialista, recebeu apoio da antiga União Soviética, de Cuba e de outros países do ex-Pacto de Varsóvia. A FNLA recebeu apoios dos EUA e do Zaire (atual República Democrática do Congo). A UNITA recebeu apoio da África do Sul no período do Apartheid e dos EUA.

No período de 1962 a 1975, Angola atravessou um surto de crescimento econômico que se acelerou a partir de 1968. O PIB cresceu em termos reais à taxa média anual de cerca de 4\% entre 1953 e 1963 , subindo para 7\% entre 1963 a 1973. Nesse ano, o hipermercado Pão de Açúcar (capitais brasileiros) inaugurava em Luanda, a capital de Angola, uma das lojas mais modernas do mundo.

A luta travada pelos três movimentos contra a dominação portuguesa em Angola forçou Portugal a negociar e a assinar com os movimentos o conhecido Acordo de Alvor, em janeiro de 1975, no qual estabelecia a constituição do governo de transição composto pelos membros do MPLA, FNLA, UNITA e representantes do governo português, que iriam transferir o poder para os movimentos de libertação e marcaram a independência para 11 de novembro daquele ano. As divergências entre os movimentos se aprofundaram, e o MPLA, que possuía o maior apoio popular e militar, saiu da frágil aliança e, no dia marcado, proclamou unilateralmente a independência de Angola em Luanda. O Brasil foi o primeiro país a reconhecer a legitimidade do governo do MPLA.

\section{Independência e a Primeira Guerra Civil}

Com a Revolução dos Cravos (25 de abril de 1974), que derrubou a ditadura de Salazar-Marcelo Caetano, Portugal inflectiu para a esquerda e tratou de retirar suas tropas de Angola, aceitando que a antiga colônia se tornasse independente, com ascensão ao poder de 
movimentos revolucionários que, através da guerrilha, lutavam havia vários anos para emancipar o país.

O Brasil reconheceu estrategicamente os movimentos de libertação, principalmente o MPLA, que era hegemônico em todo o território angolano, evitando que Angola ficasse inteiramente à mercê da ex-União Soviética e de Cuba, em uma região considerada como parte da área de fronteira e influência. Esse raciocínio levou o governo Ernesto Geisel (1974-1979) a reconhecer, juntamente com Cuba e exUnião Soviética, o MPLA sob a liderança de Dr. Antonio Agostinho Neto, que disputava o poder com a FNLA, de Holden Roberto, sustentada pelos EUA e pela República do Zaire (hoje República Democrática do Congo) e da UNITA, de Jonas Malheiro Savimbi, com apoio da África do Sul. Informes do Itamaraty indicavam que o MPLA, com domínio na capital Luanda e nas mais importantes cidades do país, tinha todas as condições para se consolidar no poder ( $O$ Estado de São Paulo, 28/02/1976, p. 10). Além do mais, era o único dos três movimentos de libertação que possuía compromissos com a cultura do país, sem se definir, nitidamente, como comunista, devido ao carácter religioso e regional de sua composição. O reconhecimento imediato permitiu dissipar as desconfianças dos angolanos, mantendo a missão em Luanda e defender seus interesses no país.

O governo Geisel não teve realmente alternativa senão reconhecer e apoiar o regime revolucionário do MPLA que se instalou em Angola, a fim de defender e consolidar os crescentes interesses econômicos e geopolíticos do Brasil na região sul da África. A solidariedade com Portugal, cuja política, sob Salazar, visava a manter as colônias, principalmente Angola, como província ultramarina, levantara contra o Brasil no continente africano desconfiança e hostilidade, alimentada mais ainda pelo carácter fortemente conservador do regime autoritário.

Solucionada a questão da independência, Angola ficou mergulhada na primeira guerra civil desde o final de 1975 a 1991, derivada do conflito entre os diferentes projetos de governo defendidos pelos movimentos de libertação. A FNLA se dissolveu como 
grupo armado, mas a UNITA abraçou a defesa do capitalismo com o apoio dos EUA e da África do Sul do regime do Apartheid, receando as possíveis influências que a vitória do movimento de esquerda do MPLA, de maioria negra, poderia causar na região Austral da África. Tal conflito civil motivou a elaboração e a realização das missões de paz da ONU em Angola em 1988, coincidentemente no momento de término da Guerra Fria em escala mundial, com a desmobilização da bipolaridade e do acirrado conflito ideológico nas relações internacionais.

As origens da guerra civil em Angola residiram em diversos fatores, entre os quais cabe mencionar: 1) os projetos diferentes para o futuro governo de Angola no imaginário dos movimentos de libertação nacional; 2) o grande montante de recursos minerais, principalmente diamantes e petróleo existentes no território angolano, que, além de atiçarem a cobiça e os interesses internacionais, em si mesmas sediavam o conflito; 3) a intervenção de países como ex-URSS, Cuba, EUA, Zaire, África do Sul e outros atores internacionais, especialmente no auge da Guerra Fria, os quais polarizaram mais ainda as disputas internas pelo controle do governo de Angola; 4) a postura tendenciosa de Portugal na elaboração e aplicação do modelo de governo de transição de colônia para a independência através do Acordo de Alvor, cujos signatários foram o governo português, o MPLA, a UNITA e a FNLA que influenciaram de forma decisiva o agravamento das disputas no país.

De 1960 até o fim do conflito bipolar, em 1989, os blocos liderados pelos EUA, o capitalista, e pela ex-União Soviética, o socialista, incentivaram e influenciaram de forma determinante a evolução do conflito angolano em suas diversas fases, da luta anticolonial para a independência, passando da guerra civil à tentativa de pacificação e resolução do conflito. O interesse despertado por Angola em ambas as potências durante a Guerra Fria encontra justificativa se são levadas em conta as riquezas minerais consideráveis no subsolo de Angola, a localização estratégica de Angola na região do Atlântico Sul, 
que derivou, sobretudo, a consideração geopolítica e geoestratégica de Angola tanto pelos EUA como pela ex-União Soviética.

Outros países que intervieram no conflito angolano seguiram, de maneira geral, as diretrizes e orientações de política externa de uma ou outra entre as duas superpotências. Terminada a Guerra Fria, EUA, Rússia e Portugal compõem a Troika de observadores e participantes ativos nas negociações de paz e monitoradores da execução dos acordos de paz em Angola, desde 1990.

Levando em consideração a íntima ligação existente entre a dimensão regional e internacional do conflito, as potências mundiais incentivaram, apoiando posições opostas. Por isso, a primeira tentativa de buscar a solução para o conflito consistiu em uma negociação conjunta, sugerida pelos EUA e conhecida como a política de linkage, a qual consistia no estabelecimento de vínculos de dependência para a resolução de problemas relacionados, como, por exemplo, a retirada das tropas cubanas de Angola.

\section{Acordos e Missões de Paz da ONU e a Segunda Guerra Civil}

Na primeira tentativa, a negociação conjunta envolveu os principais e os imediatamente implicados na disputa: Angola, Cuba, África do Sul e Namíbia com a observação dos EUA e da URSS, cujos resultados originaram a proposta de resolução do conflito, expressa nos Acordos de Nova Iorque, assinados na sede das Nações Unidas entre Angola, Cuba e África do Sul em 22 de dezembro de 1988, e bilateral entre Angola e Cuba, que previa a retirada simultânea das tropas cubanas e sul-africanas de Angola, assim como conferia a independência da Namíbia. Nasceu desses Acordos a UNAVEM I (Missão de Verificação das Nações Unidas em Angola), sob proposta do Secretário-Geral da ONU para fiscalizar a retirada dos cubanos. A UNAVEM I foi a missão de manutenção da paz bem-sucedida, expressa na rapidez e agi- 
lidade com que os Acordos de Nova Iorque foram cumpridos. Em 21 de março de 1990, a Namíbia proclamou a independência com a vitória da SWAPO (South-West Africa Peoples Organization) nas eleições realizadas em novembro do ano anterior e, em 26 de maio de 1991, a retirada das tropas cubanas foi completada.

Em 31 de maio de 1991, depois de muitos meses de negociação entre representantes do governo angolano - MPLA e da UNITA sob a mediação da Troika de observadores, são assinados os Acordos de Bicesse em Portugal, e a ONU é convidada a fiscalizar os Acordos com a criação da UNAVEM II. Rubricaram os Acordos de Paz de Angola: José Eduardo dos Santos (presidente de Angola); Jonas Malheiro Savimbi (líder da UNITA); Cavaco da Silva (Primeiro-Ministro português); Peres Cuellar (Secretário-Geral das Nações Unidas); James Baker (secretário pela política externa dos EUA), Alexandre Brassmertnykh (secretário para política externa da URSS) e Joweri Musevini (presidente da Organização da Unidade Africana OUA). Os acordos de Bicesse estabeleciam o cessar-fogo, a unificação das tropas da UNITA e do governo em um exército único e a realização de eleições gerais, com ampla liberdade partidária. A UNITA e a FNLA registraram-se como partidos. Savimbi foi recebido em Luanda no Palácio de Futungo de Belas pelo presidente José Eduardo dos Santos, sucessor de Agostinho Neto (primeiro presidente de Angola, falecido em 1979).

A UNAVEM II tinha como objetivo primordial de seu mandato a supervisão e a implementação dos Acordos de Bicesse, incluindo a supervisão das eleições para o executivo e o legislativo do país e que ocorreriam nos dias 29-30 de setembro de 1992. A ONU deu destaque às eleições de 1992 refletidas em uma série de expectativas com relação ao acontecimento, sobretudo com a possibilidade de unificação nacional e pacificação efetiva de Angola. Mas, essas expectativas não se confirmaram. A UNITA contestou os resultados das eleições de setembro de 1992, embora estudos efetuados pela ONU e com participação de observadores independentes considerarem que 
as eleições foram justas e legítimas, e que a incidência de pequenas fraudes eleitorais se deu nas áreas controladas pela UNITA, onde a propaganda política de grupos opositores foi proibida e tentou-se impedir o voto contra a UNITA. Com o resultado das eleições, o MPLA tornou-se governo legítimo de Angola, e a UNITA reagiu a essa situação, retomando a guerra civil com toda a força. A segunda guerra civil de Angola iniciou em 30 de outubro de 1992 após a divulgação do resultado das eleições.

Nessas primeiras eleições multipartidárias realizadas em Angola, o MPLA obteve 53,7\% dos votos válidos e a UNITA 34,1\%, conquistando 70 cadeiras no parlamento. $\mathrm{O}$ candidato presidencial do MPLA, José Eduardo dos Santos, obteve 49,57\% dos votos e Savimbi, 40,07\%. Portanto, havia a necessidade de realização de um segundo turno. Mas a UNITA não aceitou o resultado das urnas, alegando fraude, embora os observadores internacionais, inclusive da ONU, que haviam monitorado as eleições, considerassem terem sido livres e justas. Em outubro, antes do segundo turno, a UNITA arregimentou suas tropas e tentou derrubar o governo a partir da capital. Luanda amanheceu em polvorosa no dia 30 de outubro de 1992, com violentos confrontos que duraram quase uma semana e deixaram um saldo de quase mil mortos. A UNITA foi expulsa da capital e instalou seu quartel-general na província do Huambo. A essa altura, o regime socialista angolano havia sido substituído gradualmente pela economia de mercado, com abertura ao capital estrangeiro e pluripartidarismo, o Muro de Berlim tinha caído e a União Soviética se desfacelava. O nacionalismo anticomunista de Savimbi já não obtinha ressonância nem nos Estados Unidos.

A atuação da UNAVEM II não se encerra com o fracasso do resultado das eleições divulgadas em outubro de 1992, cuja característica foi "quem ganha leva tudo". Ao contrário, a ONU reconhece o retorno do conflito bélico em Angola e promove extensões desta missão através de resoluções do Conselho de Segurança. Durante o seu mandato, a UNAVEM II foi demasiadamente 
complacente com a UNITA, mesmo quando este grupo insistia em violar os Acordos de Bicesse, pouca obediência às resoluções e sanções aprovadas pela ONU. O imobilismo da ONU em regular o conflito angolano derivou do seu Conselho de Segurança, composto pelas grandes potências do cenário político internacional, e que, durante o período de 1989 a 1994, verificava-se um fortalecimento dos EUA e a retração da Rússia devido ao fim da Guerra Fria. Os dois países envolveram-se profundamente na guerra civil de Angola, e seus interesses continuavam nítidos nesse país, influenciando sobremaneira a ação da comunidade internacional para o fim do conflito. Os EUA viam na paz uma via para a UNITA chegar ao poder com custos políticos e financeiros mínimos, enquanto que, para os outros países envolvidos no conflito, o envolvimento dos EUA era uma garantia suficiente com que se desenrolariam os acontecimentos em Angola.

O fim da Guerra Fria, a descoberta de reservas de petróleo consideráveis na costa angolana, o estatuto legal depois das eleições de 1992 e as perspectivas de negócios levaram os EUA, totais apoiadores da UNITA até as eleições, a reconhecerem finalmente o governo de Angola em 1993, abrindo caminho para as sanções contra a UNITA por parte da ONU, o que implicou naturalmente em uma gradual inversão das forças políticas, diplomáticas e militares em favor do governo legítimo de Angola.

A UNAVEM II é concluída em 1995 com uma percepção nítida de uma empreitada mal-sucedida, mas não encerrada. Em substituição, foi criada a UNAVEM III, como resultado da assinatura das negociações do Protocolo de Lusaka em 20 de novembro de 1994, cujo objetivo era auxiliar o governo angolano e a UNITA na consolidação do projeto de reconciliação nacional, por meio do respeito pelo resultado das eleições efetuadas em 1992 e pela busca de uma modalidade de participação nas instâncias do poder da parte derrotada nas eleições. Os primeiros problemas com o Protocolo de Lusaka e para sua implementação pela UNAVEM III começaram com a ausência de Jonas Savimbi 
no ato da assinatura dos acordos, deixando um sentimento generalizado de descaso por parte da UNITA e sua conseqüente debilitação.

De fato, o Conselho de Segurança da ONU reconheceu em várias resoluções a UNITA como a promotora dos maiores obstáculos à concretização do Protocolo de Lusaka, bem como ressaltou os esforços positivos do governo de Angola na criação do GURN (Governo da Unidade e Reconciliação Nacional). O líder da UNITA, Jonas Savimbi, mais uma vez não compareceu na posse do GURN - governo de coalizão nacional, agindo de forma semelhante quando da assinatura do Protocolo de Lusaka, reduzindo estrategicamente a legitimidade desta nova administração do governo e, conseqüentemente, restringindo as chances de sucesso da reunificação do país.

Com a inauguração do GURN, a UNAVEM III encerra as suas atividades em junho de 1997. Durante o planejamento e a elaboração da UNAVEM III, buscou-se superar as dificuldades que levaram ao insucesso da UNAVEM II, mas continuaram o imobilismo e a relutância do Conselho de Segurança em inibir efetivamente a violação dos acordos, notadamente por parte da UNITA. No Conselho de Segurança da ONU, houve uma excessiva confiança na boa-vontade cooperativa de partes historicamente opostas (MPLA e UNITA), não tomando medidas eficazes e enérgicas necessárias para controlar o conflito angolano.

A missão da UNAVEM III foi substituída pela MONUA (Missão de Observação das Nações Unidas em Angola) em 30 de junho de 1997. Seu mandato consistia em prestar auxilio às partes envolvidas no conflito na busca da consolidação da paz e reconciliação nacional, em uma tentativa de estabelecer um ambiente favorável e duradouro de estabilidade, desenvolvimento democrático e reabilitação do país, monitorando o clima político com a retirada gradual dos funcionários da ONU, na medida em que a extensão e presença da administração estatal pelo país e a neutralidade da polícia (incluindo a incorporação de membros da UNITA) fossem verificadas. A MONUA, dessa forma, foi projetada para ser a última das operações das Nações Unidas em Angola. 
A missão da MONUA sai frustrada pelo tom nas resoluções do Conselho de Segurança, reconhecendo que a situação de Angola representa um perigo para a comunidade internacional. Seus representantes apelam para que todos os países-membros da ONU evitem taxativamente qualquer tipo de comércio com a UNITA, especialmente no caso de diamantes, que monitorem e bloqueiem quaisquer fluxos financeiros ligados à UNITA e a movimentação dos seus membros, incluindo o fechamento de suas representações. Antes de encerrar a MONUA, o Conselho de Segurança lamenta veementemente o abate de duas aeronaves a serviço da ONU em Angola na região controlada pela UNITA. Em janeiro de 1999, o presidente de Angola, José Eduardo dos Santos, declara que a presença da ONU em Angola não era mais necessária, o que levou a encerrar as atividades da MONUA em 26 de fevereiro de 1999 com a retirada do seu pessoal e estabelecido apenas um escritório das Nações Unidas sem mandato e metas específicas.

\section{O Fim do Conflito, a Normalização e o Relançamento da Economia}

A guerra civil em Angola, durante os vinte e sete anos, deixou milhares de mortos, mutilados, refugiados e milhões de deslocados internos, além de minas terrestres. Com o fim das missões militares da ONU, o governo de Angola cessou qualquer tipo de negociação ou entendimento com a UNITA, e as duas partes se engajaram intensamente na guerra civil, sem tréguas até 2002. Com a morte em combate de Jonas Savimbi, líder da UNITA, em 22 de fevereiro de 2002, foram criadas condições para uma certa margem de manobra na resolução definitiva do conflito angolano.

Agindo de uma forma considerada sensata, o governo de Angola não declarou uma vitória do MPLA nem do governo angolano, mas aproveitou as circunstâncias para estabelecer um acordo entre 
as partes beligerantes, com vantagens mútuas, seja para o governo, com a pacificação do território, seja para UNITA. Evitando sérios riscos de sua dissolução e fragilidade para continuar a guerra, consegue-se finalmente a paz definitiva. $\mathrm{Na}$ seqüência desses acontecimentos, o governo de Angola declarou unilateralmente um cessar-fogo e iniciou uma série de contatos com as lideranças da UNITA, os quais evoluíram para as negociações de paz efetiva, culminando na assinatura do Memorando de Entendimento do Luena em 4 de abril de 2002.

Com o fim da guerra civil angolana, a UNITA reunificou-se (no momento da crise e sob o efeito das sanções impostas pela ONU depois dos Acordos de Lusaka, surgiu dissidência de muitos membros que fundaram a chamada UNITA-Renovada, reconhecida pela ONU e pelo governo de Angola) como partido político e reabilitouse, participando da vida política de Angola. No cenário político, a principal pauta das discussões passou a ser o planejamento e a execução das eleições gerais que vêm sendo adiadas desde 2006, justamente com objetivos de melhorar as infra-estruturas que permitam acesso a todo o território nacional, a consolidação da paz, a reconciliação nacional, evitando-se durante esse período qualquer descuido que possa pôr em risco as estratégias reguladoras do país.

\section{Divisão Político-Administrativa, Hidrografia e Clima}

Angola fica situado na costa da África Austral ao sul do Equador, nas latitudes $4^{\circ} 22^{\prime}$ e $18^{\circ} 02^{\prime}$ e as longitudes $11^{\circ} 41^{\prime}$ e $24^{\circ} 05^{\prime}$, possuindo um extenso território com $1.246 .700 \mathrm{~km}^{2}$, inclui 7270 $\mathrm{km}^{2}$ do enclave de Cabinda e uma fronteira marítima de $1.650 \mathrm{~km}$. Tem suas fronteiras limitadas ao norte pelas Repúblicas do Congo (Brazzaville e Democrática), a leste pela República Democrática do Congo e Zâmbia, no sul pela República da Namíbia e a oeste pelo Oceano Atlântico. 
Angola tem hoje 18 províncias (Estados): Uige, Zaire, LundaNorte, Lunda-Sul, Malanje, Luanda, Benguela, Huambo, Huíla, Cabinda, Moxico, Kuanza-Norte, Kuanza-Sul, Bengo, Namibe, Quando-Cubango, Cunene e Bié. Mais de 75\% da população pertence ao grupo étnico banto, que abrange os grupos etno-lingüísticos quicongo, quimbundo, umbundo, lunda-quioco, ganguela, n'haneca-humbe, hereró, ambós e xindonga. Todos esses grupos se dividem em subgrupos de línguas, mas o português é a língua oficial. Do ponto de vista religioso, professam-se crenças africanas tradicionais, para além de cristianismo (protestantes e católicos) e de religiões mistas entre as tradicionais e o cristianismo.

A superfície de todo o território angolano, para se ter uma idéia mais perfeita da sua grandiosidade, é 14 vezes maior que Portugal ou, ainda, 96\% das áreas reunidas da Espanha, França e Itália. Ao observar-se o mapa físico de Angola, nota-se a existência de uma densa rede hidrográfica e orla marítima. Seus rios não são todos navegáveis, limitando-se a pequenos trechos nos quais isso é possível.

Os rios maiores são: Rio Zaire: navegável em $150 \mathrm{~km}$, tem um caudal de setenta mil metros cúbicos por segundo $\left(70.000 \mathrm{~m}^{3} / \mathrm{s}\right)$, classificando-se, por isso, logo após o Rio Amazonas, que tem oitenta mil metros cúbicos por segundo $\left(80.000 \mathrm{~m}^{3} / \mathrm{s}\right)$ e que é o rio mais caudaloso do mundo; Rio Dande: navegável em $60 \mathrm{~km}$; Rio Bengo: navegável em 196 km; Rio Kuanza: navegável em 258 km, é o maior rio dos que possuem a bacia hidrográfica inteiramente situada em Angola, totalizando seu percurso em aproximadamente mil quilômetros; Rio Cunene: navegável em $190 \mathrm{~km}$, sendo, em extensão, o segundo maior rio de Angola com percurso de $945 \mathrm{~km}$.

Dos desníveis bruscos do solo de Angola, resultam, na formação freqüente de correntezas e cataratas nos cursos de grande parte de seus rios, constituindo apreciáveis fontes de energia em potencial e motivos da atração turística pelas belezas, por vezes surpreendentes de quedas, como as de Calandula, na Província de Malanje. 
Em relação ao clima de Angola, dentro da classificação geral situa-se nas zonas climática equatorial e tropical (quentes e húmidas). A sua sucessão rápida de altitudes, como as zonas do litoral, subplanálticas e planálticas, é determinante nos climas locais, regionais com características diferenciadas. No entanto, dois outros fatores, como a latitude e a corrente fria de Benguela, resultam ainda uma maior diversidade de climas. Todavia, pela ação conjunta dos fatores de ordem litosférica, geográfica e hidrosférica, os vários elementos do clima diferem acentuadamente do litoral ao planalto e, até, do litoral norte para o litoral sul, registrando-se, em muitos casos, desvios profundos das características de tais zonas. Angola tem apenas duas estações: 1) tempo do Cacimbo ou inverno, isto é, época não-chuvosa, que vai de maio a setembro; 2) tempo das chuvas ou verão, que se estende de outubro a abril, com temperaturas anuais que variam de $\left(-4,5^{\circ} \mathrm{C}\right)$ no inverno a $\left(40,5^{\circ} \mathrm{C}\right)$ no verão, em algumas regiões como Tchivinguiro e Chienge, todas na província da Huíla, respectivamente.

Angola possui vastos recursos florestais concentrados, fundamentalmente na província de Cabinda, na floresta de Maiombe, onde predominam madeiras de expressivo valor econômico, tais como paupreto, ébano, sândalo africano, pau-raro e pau-ferro. O país possui numerosos recursos minerais, destacando-se pelo seu aproveitamento econômico o petróleo, os diamantes, o ferro, o manganês, o cobre, os mármores, e minerais raros. As principais bacias petrolíferas em exploração situam-se junto à costa nas províncias de Cabinda, Zaire, no norte, com uma produção total no país, atualmente, de quase 2.000.000 de barris de petróleo bruto por dia. A área diamantífera da Lunda-Norte é considerada das mais importantes do mundo. A fauna é bastante rica e diversificada, destacando-se a presença da palanca negra gigante (nome científico: bippotragus niger Varianni), localizada no Parque Nacional de Cangandala-Malanje, espécie bastante rara da fauna angolana, atual símbolo da principal transportadora aérea angola, a TAAG (Transportes Aéreos de Angola - Angola Airlines). 


\section{Relações Econômicas com o Brasil}

As relações econômicas entre Brasil e Angola marcam o início das relações afro-brasileiras, quando para o Brasil foram trazidos os primeiros africanos na condição de escravos para trabalhar nas lavouras de cana-de-açúcar. O tráfico de escravos foi a base do intercâmbio comercial por cerca de 470 anos. Sem os escravos, o comércio Brasil-África seria praticamente inexistente e, por conseguinte, outra seria a história do Brasil. Angola participou ativamente da formação do povo brasileiro. Além dos escravos, outros produtos compunham a pauta das exportações angolanas para o Brasil, tais como: ouro em pó, marfim, óleo de amendoim, cera branca e amarela, azeite de dendê, etc. Em contrapartida, o Brasil exportava produtos como: aguardente, açúcar, tabaco e outros, reexportava produtos europeus e asiáticos (tecidos, lenços, vinho, manteiga, etc.). A função do Brasil nessas trocas era garantir a permanência de Portugal em Angola, aproveitando seus colonos e, com isso, garantindo também o controle do principal centro abastecedor de mão-de-obra para o Brasil.

A independência brasileira em 1822 abriu uma perspectiva de fortalecimento das relações através da proposta de anexação de Angola pelo Brasil (União Brasil-Angola), a qual se daria mediante o apoio brasileiro aos movimentos rebeldes em Luanda e Benguela contra a Coroa portuguesa. $\mathrm{Na}$ verdade, esses movimentos representavam interesses dos negociantes de escravos, os quais viam na possibilidade da União Brasil-Angola uma forma de assegurar a continuidade do tráfico, visto que entre Brasil e Inglaterra não havia sido firmado nenhum acordo, ao contrário de Portugal que, em 1836, assinou acordo com ingleses, pondo fim ao tráfico de escravos. No entanto, pressionado pelos ingleses, o Brasil assinou um acordo com Portugal, no qual se comprometia em não incorporar ao seu império as colônias portuguesas. 
Terminado o tráfico em 1850 no Brasil, as relações entraram em declínio. Vários fatores contribuíram, entre eles a inserção definitiva de Angola, assim como das demais colônias africanas, no circuito capitalista, após a Conferência de Berlim, em 1885: Angola passou de exportadora de braços escravos para exportadora de matérias-primas agrícola e mineral. Isso provocou uma mudança qualitativa nas relações Brasil-Angola, as quais perderam o carácter de complementaridade e tornaram-se concorrenciais, assim permanecendo até a independência de Angola. Como economia primária exportadora, concorria com alguns produtos brasileiros, principalmente o café, de que Angola era um dos principais produtores mundiais.

\section{Considerações Finais}

A população atual de Angola é de cerca de 16.000.000 de habitantes. A média da densidade populacional é muito baixa, cerca de 8 habitantes por $\mathrm{km}^{2}$. A cidade de Luanda abriga mais de 4.000.000 de habitantes, mas ela foi projetada para 600 mil habitantes.

Hoje, com a paz definitiva, Angola passa por um profundo processo de restauração estrutural, com forte cooperação e recursos aportados pelo governo chinês, reorganizando e reconstituindo a sua esfera política, a sociedade e economia. A região da África Austral está com boa estabilidade política graças ao fim de conflitos de Angola, ao amadurecimento da democracia racial na África do Sul, e na Namíbia, aos progressos da democracia em Moçambique e ao fim também da guerra civil na República Democrática do Congo.

Nos últimos quatro anos, Angola cresce economicamente a ritmo de 20,5\% em 2005 com picos de $26 \%$ em 2006 e projeção de $29 \%$ para 2008, porque os investidores nacionais e estrangeiros reconhecem que o curso trilhado para a consolidação da paz é efetivamente seguro, e irreversível. 
Angola é o maior parceiro comercial da China na África, superando a África do Sul. Em 2005, os negócios foram de U\$ 7.000.000.000; em 2006, foram de U\$ 9.300.000.000, estimando-se para 2008 U\$10.000.000.000. A China importou $18,2 \%$ equivalente a 94.000 .000 de barris de petróleo de Angola, do total das importações chinesas de petróleo.

\section{Referências}

BOAVIDA, Américo. Angola: cinco séculos de exploração portuguesa. Rio de Janeiro: Ed. Civilização Brasileira, 1967.

BRAVO, Manuel. Angola: transição para a paz, reconciliação e desenvolvimento. Lisboa: Ed. Hugin, 1996.

DIRECÇÃO DOS SERVIÇOS DE ECONOMIA. Angola: provincia de Portugal em África. Luanda: Gráfica de Publicações Unidade, 1953.

JOSE, Joveta. Estratégias de integração da Odebrecht em Angola (Dissertação de Mestrado). São Paulo: PUCSP, 2002.

MENESES, Solivar Silva. Mamma Angola: sociedade e economia de um país nascente. São Paulo: EDUSP, 1999.

OLIVEIRA, Henrique Altimani de. Política externa brasileira e as relações comerciais Brasil- Africa (Tese de doutoramento). São Paulo: USP, 1987.

SANTOS, José Eduardo dos. "Discurso sobre os problemas de Angola". Revista Tribuna Diplomática (Embaixada de Angola no Brasil), ano I no 2, 2000.

SANTOS, Nilcea Lopes Lima. União Brasil-Angola: uma hipótese na independência. Brasilia: Ed. UNB, 1979.

SILVA, Paula Frassinetti Costa da. A trajetória política do reconbecimento da independência de Angola pelo Brasil. Brasília: UNIB, 1989.

VICENTE, São. Petróleo, política econômica e estratégia em Angola. Luanda: Ed. INALD, 1994. 


\title{
13 \\ DIÁSPORA AFRICANA: \\ PARAÍSO PERDIDO \\ OU TERRA PROMETIDA
}

\author{
José Antônio dos Santos
}

O Brasil é um país extraordinariamente africanizado. E só a quem não conhece a África pode escapar o quanto há de africano nos gestos, nas maneiras de ser e viver e no sentimento estético do brasileiro. Por sua vez, em toda a outra costa atlântica se podem facilmente reconhecer os brasileirismos. Há comidas brasileiras na África, como há comidas africanas no Brasil. Danças, tradições, técnicas de trabalho, instrumentos de música, palavras e comportamentos sociais brasileiros insinuaram-se no dia-a-dia africano. [...] Com ou sem remorso, a escravidão foi o processo mais importante de nossa história. [...] O escravo ficou dentro de todos nós, qualquer que seja a nossa origem. (Costa e Silva, 2003)

A palavra diáspora foi originalmente usada no Antigo Testamento para designar a dispersão dos judeus de Israel para o mundo. Recentemente, tem se aplicado o mesmo vocábulo, por analogia à condição judaica, aos movimentos dos povos africanos e afro-descendentes no interior do continente negro ou fora dele. A diáspora traz em si a idéia do deslocamento que pode ser forçado como na condição de escravo, resultado de guerras, perseguições políticas, religiosas ou desastres naturais. Também pode ser uma dispersão incentivada ou espontânea de grandes massas populacionais em busca de trabalho ou melhores condições de vida.

A partir desses sentidos possíveis, a palavra diáspora tem servido para múltiplos usos, por exemplo, como conceito nos estudos culturais e póscoloniais e como motivo de identificação étnico-racial na busca do paraíso perdido dentro e fora da África. Também tem se prestado aos interesses políticos, ideológicos e econômicos que buscam aglutinar e, em alguns casos, levar de volta para o continente de origem africanos e afro-descendentes espalhados por todo o globo terrestre. Para fins desse traba- 
lho, vamos refletir sobre esses três usos modernos do termo diáspora, o que nos leva a um rápido retorno no tempo.

A diáspora ou a dispersão dos povos africanos pela Europa, Ásia e América se produziu em escala massiva durante o período do tráfico de escravos entre os séculos XV e XIX. Esse é um dos movimentos migratórios mais espetaculares da História moderna, sendo que os cálculos da travessia forçada pelo Oceano Atlântico oscilam de dez a cinco milhões de pessoas que teriam sido arrancadas da África e trazidas para as Américas. Sem dúvida, houve presença africana em praticamente todo o mundo conhecido anterior ao início do tráfico internacional no século XVI.

Os africanos foram soldados no Império Romano e entraram, através do Deserto do Saara, no Oriente Médio, na Ásia e na China, trabalharam em plantações ou como estivadores, comerciantes e tripulantes de barcos no Oceano Índico, serviram de domésticos, ourives e cortesãs no mundo islâmico. Durante a Idade Média, entre os anos de 700 a $1.400 \mathrm{~d}$. C., os europeus foram superados pelos africanos no comércio e na produção de mercadorias manuseadas. Os grandes centros comerciais e de finanças, as cidades mais ricas e os maiores mercadores se encontravam na África (Davison, 1981).

O tráfico internacional criou um mercado de pessoas que desestruturou reinos e nações, arrasou regiões, incrementou guerras e revoluções no continente africano. Por outro lado, envolveu um número expressivo de pessoas no comércio infame, a partir do interior, intermediários africanos vendiam prisioneiros de guerras e desafetos para os comerciantes europeus estabelecidos em fortalezas no litoral. O comércio transatlântico de pessoas e mercadorias incrementou o acúmulo de riquezas na Europa e ajudou a detonar o processo de industrialização na Inglaterra. Ao mesmo tempo, era interrompido o processo de desenvolvimento peculiar à África e rompidas as redes comerciais. A mão-de-obra mais preciosa e habilitada, homens e mulheres, jovens e saudáveis, foi seqüestrada e obrigada ao trabalho em terras distantes. 


\section{O "Atlântico Negro" \\ e o Pan-Africanismo}

No final do século XIX, quando os europeus ocupam, de fato, o continente, resultado do desenvolvimento de novas tecnologias e devido às necessidades econômicas, a colonização e a exploração direta dos africanos e suas riquezas em seu próprio território passaram a substituir o tráfico de pessoas. Em todo aquele período, o trânsito de pessoas, culturas, tecnologias e conhecimentos, estabelecidos entre a África e o resto do mundo, foi constante e intenso em todas as direções.

Nos anos de 1830 a 1870, em torno de 8.000 retornados, negros livres ou libertos, majoritariamente africanos de nascimento, conseguiram sair do Brasil e voltar ao seu continente de origem. Em embarques coletivos ou individuais, uma vez na África, eles passaram a ser reconhecidos geralmente como brasileiros, havendo variações locais: agudás no Benin, amarôs em Togo e na Nigéria, ta-bom em Gana. A maioria dessas pessoas se estabeleceu no litoral africano e começou a trabalhar e se utilizar dos conhecimentos que haviam aprendido no processo diaspórico (LIMA, 2006). O uso do idioma português, a religiosidade católica e os hábitos e costumes adquiridos no Brasil - vestimentas, culinária, folclore, estilo arquitetônico das casas - definiram uma cultura mista, reconhecida na África como brasileira, resultado do processo da diáspora, portanto, diferentemente da maioria dos africanos que não haviam deixado a terra natal.

Muitos dos retornados aprenderam novas tecnologias, conhecimentos e línguas, além das que traziam consigo. $\mathrm{O}$ trânsito que fizeram entre a África, a América e a Europa foi mais do que uma escola para alguns deles. Esse foi o caso de Mohammah Gardo Baquaqua. Escravizado na África Ocidental por volta de 1840, Baquaqua chegou ao Brasil em 1845, onde se movimentou do Recife ao Rio de Janeiro, e deste para o Rio Grande do Sul. Como escravo embarcado em navio que transportava café, chegou aos Estados Unidos, foi ao Haiti, voltou à Nova Iorque. Nessa cidade ficou por quatro anos, de- 
pois se dirigiu ao Canadá. Nesses países, ele aprendeu inglês e escreveu uma autobiografia, publicada em 1854, inclusive com fotografia, fonte de pesquisa fundamental para o resgate de sua trajetória.

Em 1857, já em Liverpool, na Grã-Bretanha, Baquaqua, além da vontade obstinada de voltar ao continente em que nasceu, não deixou mais pistas para os historiadores. Ele foi um personagem típico da diáspora. Em todo lugar que viveu, aprendeu e ensinou, mudou de nome e de religião, deixou de ser muçulmano e passou a ser católico e, após, protestante. Foi livre e escravo, mas nunca deixou de ser africano e, quando conseguiu condições materiais para registrar a sua história, o fez com o nome de batismo, marca da origem, cultura e religiosidade que carregou sempre consigo (Lovejoy, 2002).

Os africanos da diáspora procediam de um amplo leque de culturas, línguas e religiosidades diferenciadas que podiam, assim como seus descendentes, olhar para trás e ver um ponto geográfico originário comum e imaginar um paraíso perdido. Cada vez mais, a historiografia recupera essas trajetórias e mostra que não foram poucos os casos daqueles que envidaram todos os esforços para voltar à terra prometida. Há ainda os casos daqueles que vislumbraram a terra da promissão fora do continente africano, depois de circular pelo mundo atlântico, se fixaram no primeiro lugar que aportaram. O que nos dá condições de pensar sobre as experiências, os sentidos da movimentação e as trocas culturais (Reis, 2004).

Durante boa parte do século XX, as Ciências Sociais estiveram preocupadas com o debate sobre as "sobrevivências versus transformações" que operavam nas várias culturas de descendência africana nas Américas, o que, de certa forma, delimitou muito os objetos de pesquisa. Categorias como sincretismo, aculturação, hibridismo, transculturação, encontro de culturas, miscigenação cultural buscaram dar conta de uma diversidade grande de situações e aspectos culturais. Geralmente, essas categorias foram criadas para pensar as novas culturas que surgiam a partir do contato entre povos diferentes e a formação das nações, na maioria das 
vezes, com a preocupação de explicar os africanismos identificados nas sociedades americanas (Mintz, 2003).

Desde a década de 1990, no bojo das discussões sobre globalização, nacionalismo, identidade e multiculturalismo, o termo diáspora vem sendo utilizado como projeto político e acadêmico que questiona as idéias de pureza racial, identidade, território e cultura nacional. A perspectiva de estudo passa a ser balizada na redefinição crítica do lugar da África, dos africanos e seus descendentes na formação do Ocidente, o que exige um grande esforço teórico para abranger as mais diversas experiências das populações negras dispersas em escala mundial.

O sociólogo inglês Paul Gilroy insere-se no debate, trazendo à tona a noção de diáspora como um processo dinâmico, multifacetado, o qual rompe com aquelas idéias cristalizadas que tomam a diáspora africana como um fenômeno preso ao passado. Ao contrário, ele cria a metáfora do Atlântico Negro para entender a estrutura transnacional criada na modernidade e que deu origem ao sistema de comunicações globais definido pelo ir e vir de pessoas, informações e mercadorias que redefiniram novos padrões e trocas culturais. O Atlântico e a vida marítima, presentes no título e ao longo do livro, nos sugerem deslocamentos, movimentos no meio líquido e misturas que extrapolam a noção de raça, desterritorializam a cultura e nos indicam um circuito comunicativo que modifica e transcende as fronteiras étnicas e nacionais.

A racionalidade ocidental foi usada para eliminar e oprimir e sempre justificou o terror racial, a guerra ao diferente, o genocídio e a escravidão daquele que era definido como inferior. Da mesma forma, o absolutismo étnico ou eurocentrismo também serviu para relegar ao esquecimento a complexa mistura entre idéias e sistemas filosóficos e culturais europeus e africanos. Segundo Gilroy, durante a diáspora, os africanos e seus descendentes criaram um sistema ou paradigma de reflexão sobre a modernidade e suas conseqüências que continua presente nas disputas culturais e políticas atuais. Por exemplo, a dupla consciência, sinal diacrítico da história intelectual gestada no 
Atlântico Negro, seria o aspecto mais visível daquele paradigma ou o en dividido entre o continente de origem e aquele em que aportou o africano. Ele utiliza a vida e os escritos dos intelectuais negros da diáspora como W. E. B. Du Bois, Richard Wright, Martin Delany, Frederick Douglas para pensar a modernidade do ponto de vista dos afrodescendentes de língua inglesa (Gilroy, 2002).

O deslocamento e a reterritorialização da população negra redefiniram as noções de pertencimento e de identidades étnicas, o que nos leva a concluir que o mundo construído no processo da diáspora africana favoreceu o desenvolvimento e o fortalecimento de melhores condições para criticar o eurocentrismo vigente desde o seu centro. Aqueles intelectuais usaram as mesmas armas ideológicas dos agressores para questionar as bases filosóficas européias e buscaram uma unidade para a organização política em nível planetário.

William Edward Burghardt Du Bois, por exemplo, nasceu em 1868, no estado de Massachusetts, longe do sul dos Estados Unidos, onde três anos antes havia se passado a guerra civil. Conhecida entre nós como Guerra da Secessão, ao final da disputa entre as regiões sul e norte, a vitória dos nortistas terminou com a escravidão naquele país. Portanto, ele viveu tempos difíceis no processo de reconstrução do país e de redefinição dos papéis políticos, econômicos e sociais a serem ocupados pelos negros norte-americanos. W.E.B. Du Bois morreu em Gana no dia 27 de agosto de 1963, na véspera da grande Marcha pelos Direitos Civis em Washington, presidida por Martin Luther King Jr. Também conhecida como Marcha por emprego e liberdade, reuniu mais de duzentas mil pessoas na capital do país e se tornou um marco histórico para a conquista do direito ao voto e o fim da segregação racial.

A morte de Du Bois na África coroou a brilhante trajetória intelectual de um negro na diáspora. Depois de mais de noventa anos de

\footnotetext{
${ }^{1}$ Acredito que essa estratégia fez escola. Hoje, temos vários intelectuais da diáspora nas principais universidades européias e norte-americanas, como Stuart Hall, de origem negra jamaicana na Inglaterra, e Homi Babha, de origem indiana nos Estados Unidos. Além do próprio Gilroy, que circula nos corredores do meio acadêmico internacional com seus longos dreadlocks.
} 
vida e posicionamentos firmes em defesa do povo negro, ele voltou ao continente dos ancestrais, onde foi sepultado, e acompanhou o despontar de uma nova era no processo de consolidação da cidadania dos negros nos Estados Unidos. Du Bois foi o intelectual requintado, historiador, sociólogo e filósofo que estudou nos ambientes universitários solidamente vitorianos de Harvard e da Universidade de Berlim². Com todo o conservadorismo daquelas instituições de ensino, ele manteve a preocupação de pesquisar, entender e tornar pública a experiência dos negros em seu país e no mundo. Em 1903, a partir da sua trajetória intelectual, no livro de inspiração filosófica e de título poético, ele chega à formulação da idéia de dupla consciência, conceito usado por Gilroy (Du Bois, 1999). Du Bois antecipa questões relevantes para o estudo da diáspora, como os sentimentos contraditórios de nascer, fazer parte de uma cultura e nacionalidade e ao mesmo tempo, pela discriminação e pelo preconceito, se sentir excluído da história do país. A partir disso, ele constrói uma nova perspectiva histórica comum a todos os afrodescendentes, que visa aproximar a diáspora africana do continente de origem dos seus ancestrais.

Nesse sentido, Du Bois foi o líder na fundação do movimento pan-africano, que tinha entre os principais objetivos a união dos africanos e descendentes da diáspora e a criação de diretrizes autônomas para os povos africanos. Em 1919, organizou o Primeiro Congresso Pan-Africano em Paris, cujo documento final reivindicava o reconhecimento, pelas potências coloniais, da emergência do movimento de emancipação africana.

A escolha da cidade francesa para realização daquele Primeiro Congresso não era por acaso. Paris era a capital de um dos principais impérios coloniais que organizou os territórios africanos invadidos em sedes regionais e unidades administrativas relativamente indepen-

\footnotetext{
${ }^{2}$ Ironicamente, poucos anos antes da chegada de Du Bois, a cidade de Berlim acolheu a conferência que reuniu, de novembro de 1884 a fevereiro de 1885, Alemanha, França, Portugal, Bélgica e Inglaterra, as principais potências coloniais daquele período, que dividiram entre si, geopolítica e economicamente, o continente africano.
} 
dentes, pouco integradas política e economicamente entre si e voltadas exclusivamente aos interesses da metrópole.

Além do domínio pela força das armas, a colonização e o imperialismo na África se justificavam também em termos ideológicos. A filantropia era usada para promover a civilização, educar e eliminar os costumes bárbaros. A necessidade de acesso aos novos mercados consumidores para os produtos manufaturados, a busca de matérias-primas e a abundância de mão-de-obra também serviam como razões para o genocídio e a exploração. Por último, mas não menos importante, como justificativa para a pilhagem dos africanos, a ciência provava a hierarquia entre as raças, o que tornava legítimo aos superiores a colonização e o domínio dos inferiores.

Nos congressos seguintes, realizados em 1921, na cidade de Londres e, em 1923, na capital de Portugal, Lisboa, foram seguidas as lógicas do tensionamento racial e o questionamento da inferioridade atribuída aos africanos e descendentes. Ao acompanharmos os locais dos congressos, é interessante constatar que o processo instituído na diáspora africana produziu políticos, pensadores, cientistas e intelectuais, não apenas nesses grandes centros intelectuais e econômicos. Muitos daqueles que se tornaram lideranças negras saíram dos seus países de nascimento, em muitos casos, de lugares periféricos ao capitalismo central e foram para os grandes centros e capitais. Em um primeiro momento, buscaram formação acadêmica e intelectual, logo depois, colocação profissional ou política e, a seguir, se aproximaram de outras pessoas que tivessem disposição para discutir idéias, se organizar e lutar pelos mesmos objetivos ${ }^{3}$.

\footnotetext{
${ }^{3}$ O período de 1920 a 1950 foi fértil na organização de associações, partidos políticos e na concentração de intelectuais em torno de revistas e jornais anticolonialistas que buscavam a organização dos africanos da diáspora. Por exemplo, em 1934, foi fundada, em Paris, a revista LEtudiant Noir (O Estudante Negro), que uniu estudantes africanos de várias regiões, do Caribe e da América do Sul, para combater a discriminação e buscar a valorização cultural, política e artística. Esse movimento teve uma expressão significativa na literatura e ficou conhecido como Negritude.
} 
O quarto e o quinto Congressos Pan-Africanos foram realizados, em 1927, na cidade norte-americana de Nova Iorque e, em 1945, em Manchester (Grã-Bretanha), respectivamente. Nesse último congresso, houve a expressiva participação de delegados africanos que se tornaram personagens principais no processo de descolonização e independência dos países africanos, como os casos de Kwame N’krumah, em Gana, e Jomo Kenyata, no Quênia. No quinto Congresso também foi reconhecida a unidade cultural africana e acordado um programa de ação para a independência e a criação de bases políticas e econômicas para a futura unificação continental. A criação da OUA (Organização da Unidade Africana) em Addis-Abeba, Etiópia, no ano de 1963, é exemplo do empenho pela união. As idéias pan-africanistas ainda hoje permeiam os discursos de líderes políticos, Estados e organizações africanas, sempre com a finalidade de buscar a unidade política, cultural e econômica e visualizar a aproximação com os países da diáspora.

\section{A Cultura da Diáspora}

Mais próximos de nós, tivemos outras expressões do reconhecimento dos laços culturais afro-descendentes que se espalharam pelo planeta e a necessidade que as principais lideranças têm de aproximálos, bem como a capacidade de organização. Foram organizados dois Festivais Mundiais das Artes Negras. O primeiro realizado em Dakar, capital do Senegal, em 1966, depois em Lagos, Nigéria, em 1977.

Nesse sentido, também tivemos entre os dias 12-15 de junho de 2006, em Salvador, a realização da II CIAD (Conferência de Intelectuais da África e da Diáspora), cujo tema principal foi $A$ diáspora e o renascimento africano. Semelhante à primeira edição que ocorreu em Dakar, em outubro de 2004, a segunda Conferência tinha por objetivo reunir intelectuais, representantes da sociedade civil e líderes políticos para discutir sobre temas de interesse da África e dos países da diáspora. A proposta era promover um espaço para uma maior cooperação visando ao desenvolvimento comum. Contou com a pre- 
sença do presidente Luiz Inácio Lula da Silva e de outros chefes de Estado e governos africanos, além de autoridades de organismos internacionais, especialmente convidadas para o evento.

Para se ter uma idéia da importância do Brasil no quadro internacional da diáspora, para o ano de 2008 está programada a realização do terceiro Festival Mundial das Artes Negras, novamente em Dakar, o qual se propõe a homenagear o nosso país, que é a maior nação de população negra fora da África.

Não obstante, no Brasil ainda há uma grande dificuldade em pensar e reconhecer a cultura que se formou na diáspora. Desconhecemos ou não reconhecemos o que temos de africano na cultura afrobrasileira. Não poderia ser diferente. Fomos sempre educados a pensar em termos europeus. Em geral, mantemos a ilusão de uma nação branca, que não somos e nunca fomos.

No entanto, podemos nos questionar: por que o Brasil é reconhecido no mundo como uma nação de cultura eminentemente de origem africana - negra? O carnaval, o futebol, a capoeira, a feijoada, o samba são algumas manifestações culturais que representam e identificam o Brasil em todo mundo. Por que essa representação do Brasil como negro se o número de imigrantes europeus que chegou ao Brasil é praticamente o mesmo do que o de africanos?

No caso dos europeus, foram cerca de 5 milhões, concentrados basicamente em menos de cem anos de processo imigratório, da segunda metade do século XIX ao início do XX. O mesmo número, cerca de 5 milhões de africanos, chegou até aqui em três séculos de deslocamento forçado. Os imigrantes europeus vieram de vários países com línguas, religiões, costumes e culturas diferentes. Os africanos escravizados também vieram de várias regiões com línguas, religiões, costumes e culturas também diferentes. Voltamos à questão: por que a cultura brasileira é reconhecida e representada como sendo, basicamente, de matriz africana ou como dizemos afro-brasileira?

Em busca da resposta, devemos considerar que a história dos africanos não começou no encontro com os europeus, muito menos 
a partir dos embarques nos navios negreiros. Ao contrário, suas histórias e culturas são tão antigas, ricas de significados e diferentes entre si, como de resto toda a humanidade. Mais do que respostas, estamos interessados em questionamentos e talvez possamos encontrar alguns indícios para isso nos estudos da diáspora africana.

Nesse sentido, vários estudos já nos mostraram que as culturas e as identidades culturais têm uma gramática própria, as quais servem de elemento organizador das novas construções sociais e culturais o novo nasce de bases preexistentes (Hall, 1998). Ou seja, voltando ao nosso tema, os africanos já traziam em si - no corpo e no espírito - o gérmen da nova civilização que nasceria nos trópicos. À condição de africano escravizado longe da sua terra e de sua gente, somaram-se as precárias condições de sobrevivência e o vislumbre, na solidariedade, da possibilidade de superar as diferenças e sedimentar, no contato com as outras culturas, a massa que amalgamou a cultura afro-brasileira. $\mathrm{Na}$ direção diretamente contrária a toda tentativa de desumanizá-los, os africanos na diáspora buscaram a criatividade e a organização, seja pela resistência direta ou mais acomodada, mantendo a cultura que tem em si muito da origem.

Para finalizar, conforme vimos, a diáspora traz em si a idéia da dispersão, mas também devemos considerar que carrega consigo a possibilidade do regresso. O retorno dos africanos aos países de origem, recentemente, passou a ser uma prioridade. Esse é um processo preponderante para a unidade, desenvolvimento econômico e político, e para a reconciliação nacional após as guerras civis que se seguiram à independência. Em Luanda, por exemplo, foi realizado, em 2004, o primeiro Encontro em Angola de Quadros - angolanos na diáspora.

O governo de Angola se mostrava preocupado com o regresso de profissionais, técnicos, especialistas e intelectuais para ocupar os cargos vagos na administração central do país. Os traumas da guerra civil em Angola, que se estendeu de 1961 a 2002, de forma ininterrupta, levaram milhões de pessoas a se deslocarem do interior e da capital para fora do país. Naquele Encontro, compare- 
ceram angolanos provenientes de 25 países diferentes, e já foram programados mais dois fora de Angola, em Portugal e na Espanha. A necessidade de mão-de-obra especializada para desenvolver o país é tão séria e o regresso à mãe-pátria muito difícil, em virtude das condições que o governo oferece, que hoje já se entende que a cooperação e a contribuição podem vir de qualquer lugar onde os angolanos estiverem. É óbvio que, nesse caso, a preocupação é seletiva e dirigida a uma minoria de angolanos bem-sucedidos. A grande maioria dos angolanos da diáspora continua a vida como refugiados de guerra, ou subnutridos e subempregados em alguns países do continente, na Europa ou na América.

Nas festas populares, realizadas durante séculos e ainda hoje recriadas todos os anos no Brasil, termos como Congo, Cabinda, Guiné, Queto e Moçambique são proferidos de norte a sul do país - como o nosso Maçambique, aqui de Osório. Todas essas denominações vieram da África e hoje são reinos poderosos no imaginário e no cotidiano das pessoas (Mello e Souza, 2002). Por outro lado, nenhuma cidade do mundo está tão presente nas músicas e cantigas brasileiras como Luanda. Além disso, muitas meninas e mulheres levam esse nome, apesar de poucos brasileiros serem capazes de localizá-la com precisão no mapa - Angola, na África.

A partir das novas perspectivas de estudos que alguns chamam pós-coloniais, estudos culturais, mas podemos chamar também de estudos da diáspora, vislumbramos a possibilidade teórica de inverter a lógica usual na produção do conhecimento, geralmente, do centro para a periferia. Os civilizados estudam os bárbaros, os superiores dominam e investigam os inferiores, colonizados. Podemos pensar a partir de outras perspectivas, da África para Europa, da Ásia para a Europa, dos árabes para os judeus, dos países da diáspora para os grandes centros do conhecimento, geralmente localizados nos Estados Unidos e em países europeus. A partir de novos paradigmas, talvez possamos encontrar mais do que outras questões e outros objetos de pesquisa, algumas respostas surpreendentes para as nossas perguntas triviais. 


\section{Referências}

ALENCASTRO, Luis Felipe. O trato dos viventes. Formação do Brasil no Atlântico Sul. São Paulo: Cia. das Letras, 2000.

APPIAH, Kwame Anthony. Na casa de meu pai. A África na filosofia da cultura. Rio de Janeiro: Editora Contraponto, 1997.

BELLUCCI, Beluce (Coord.). Introdução à História da África e da cultura afrobrasileira. Rio de Janeiro: CCBB/RJ e CEAA/UCAM, 2003.

BENJAMIN, Roberto. A África está em nós. Ed. Grafset, 2004.

BHABHA, Homi. O local da cultura. Belo Horizonte: Ed. da UFMG, 1998.

BORGES, Edson. Racismo, preconceito e intolerância. Rio de Janeiro: Ed. Atual, 2002.

BRUNSCHWIG, Henri. A partilha da Africa. Ed. Perspectiva, 2004.

CASCUDO, Luis Câmara. Made in Africa. São Paulo: Global, 2001.

CASHMORE, Ellis. Dicionário de relações étnicas e raciais. São Paulo: Selo Negro Edições, 2000.

COSTA E SILVA, Alberto da. A enxada e a lança: a África antes dos portugueses. Rio de Janeiro: Ed. Nova Fronteira, 1996.

- A manilha e o libambo: a África e a escravidão. Rio de Janeiro: Nova Fronteira, 2002.

. Um rio chamado Atlântico: a África no Brasil e o Brasil na África. Rio de Janeiro: Ed. Nova Fronteira, 2003.

DAVIDSON, Basil. Os africanos. Uma introdução a sua história cultural. Lisboa: Edições 70, 1981.

DU BOIS, W.E.B. As almas da gente negra. Rio de Janeiro: Lacerda Ed., 1999.

FAGE, J. D. História da África. Lisboa: Edições 70, 1995.

FROBENIUS, Leo. A gênese africana. Contos, lendas e mitos da África. Ed. Landy, 2005.

GILROY, Paul. O Atlântico negro: modernidade e dupla consciência. Rio de Janeiro: Ed. 34; Universidade Cândido Mendes, 2002.

HALL, Stuart. A identidade cultural napós-modernidade. Rio de Janeiro: DP\&A, 1998. . Da diáspora. Belo Horizonte: Ed. da UFMG, 2003.

HAMPATÉ BA, Amadou. Amkoullel, o menino fula. São Paulo: Pallas Athena e Casa das Áfricas, 2003. 
HERNANDEZ, Leila Leite. A África na sala de aula. SP: Ed. Selo Negro, 2005.

LIMA, Mônica. "A vitória sobre as correntes. Os libertos no Brasil e seu retorno à África, 1830-1870”. Texto apresentado no IV Congresso Brasileiro de Pesquisadores Negros (Salvador, 11/09/2006). Texto inédito.

LOPES, Nei. Enciclopédia brasileira da diáspora africana. São Paulo: Selo Negro Edições, 2004.

LOVEJOY, Paul E. "Identidade e a miragem da etnicidade. A jornada de Mahommah Gardo Baquaqua pelas Américas". Afro-Ásia (UFBA) n 27, 2002, p. 9-39.

MELLO E SOUZA, Marina de. Reis negros no Brasil escravista: história da festa de coroação do Rei Congo. Belo Horizonte: Editora UFMG, 2002.

MINTZ, Sidney W. e PRICE, Richard. O nascimento da cultura afro-americana. Uma perspectiva antropológica. Rio de Janeiro: Pallas; Universidade Cândido Mendes, 2003.

MUNANGA, Kabengele (Org.). História do negro no Brasil: resistência, participação e contribuição. Brasilia: Fundação Cultural Palmares, 2004.

OLIVEIRA, Nelson S. de. Vultos negros na história do Brasil. Guia de direitos do brasileiro afro-descendente. Brasília, 2001.

REIS, João José. “África e Brasil entre margens: aventuras e desventuras do africano Rufino José Maria, c. 1822-1853”. Estudos Afro-Asiáticos (RJ), ano 26, nº 2, 2004, p. 257-302.

SAID, Edward W. Orientalismo: o Oriente como invenção do Ocidente. São Paulo: Companhia das Letras, 1990.

SCHWARCZ, Lilia Moritz; QUEIROZ, Renato da Silva (Org.). Raça e diversidade. São Paulo: EDUSP, 1996.

. Negras imagens. São Paulo: EDUSP, 1996.

THOMAS, Omar Ribeiro. Ecos do Atlântico Sul. Rio de Janeiro: UFRJ/FAPESP, 2002.

VISENTINI, Paulo G. F, RIBEIRO, Luiz Dario e PEREIRA, Analúcia D. Breve História da África. Porto Alegre: Ed. Leitura XXI, 2007.

WESSELING, H. L. Dividirpara dominar. Rio de Janeiro: UFRJ/Revan, 1998. 


\section{A HISTÓRIA AFRICANA NAS SALAS DE AULA: DIÁLOGOS E SILÊNCIOS ENTRE A LEI No 10.639/03 E OS ESPECIALISTAS ${ }^{1}$}

\section{Anderson Ribeiro Oliva}

O recente debate montado no Brasil em torno da abordagem da história africana nas escolas tem resultado em algumas positivas experiências. Cursos de extensão, qualificação, especialização, palestras e seminários ocorrem nos mais diversos espaços e, quase sempre, para uma platéia atenta e numerosa. No entanto, se a Lei Federal n ${ }^{\circ} 10.639$ / 03 pode ser considerada uma das forças propulsoras desse quadro, percebemos um certo desconhecimento sobre sua regulamentação. Ao mesmo tempo, a legislação educacional que a precede parece ser de conhecimento de poucos. Se, até meados dos anos 1990, a presença dos estudos africanos nos programas curriculares e nos livros escolares brasileiros pode ser considerada insignificante, ${ }^{2}$ o mesmo não pode ser dito do período subseqüente, principalmente a partir da publicação dos Parâmetros Curriculares Nacionais (PCNs) da área de História, em 1998. Em um claro reflexo dessas mudanças, podemos encontrar, a partir de 1999, livros didáticos de História, utilizados entre a $5^{\mathrm{a}}$ e a $8^{\mathrm{a}}$ série do Ensino Fundamental, os quais incluíam em seus volumes pelo menos um capítulo sobre a história africana, quase sempre vinculada ao período que se estende do século VII ao XVIII. ${ }^{3}$

\footnotetext{
${ }^{1}$ Este trabalho resulta de investigação que recebeu apoio financeiro da Coordenação de Aperfeiçoamento de Pessoal de Nível Superior (CAPES).

${ }^{2} \mathrm{O}$ continente africano, quase sempre, aparecia retratado de forma secundária, associado ao périplo marítimo dos séculos XV e XVI, ao tráfico de escravos e aos processos históricos do Imperialismo, Colonialismo e das Independências na África e na Ásia na segunda metade do século XX.

${ }^{3}$ Ver os seguintes livros didáticos: Macedo e Oliveira (1999); Maranhão e Antunes (1999) e Schmidt (1999).
} 
Talvez, como um potencializador desse processo - apesar de seus efeitos estarem ainda sob avaliação e os resultados obtidos precisarem de uma mensuração mais detalhada -, em janeiro de 2003, foi promulgada a Lei $\mathrm{n}^{\circ} 10.639$, que, alterando o texto da LDB (Lei de Diretrizes e Bases da Educação), tornou obrigatório o ensino da história africana nas escolas brasileiras, já que os PCNs apenas sugeriam os conteúdos. Seguiu-se a essa lei, já em 2004, a formulação das Diretrizes Curriculares Nacionais para a Educação das Relações Étnico-Raciais e para o Ensino de História e Cultura Afro-Brasileira e Africana. Todos esses documentos sinalizavam para a importância ou para a obrigatoriedade da introdução do estudo da História da África nas escolas brasileiras de Ensino Fundamental e Ensino Médio ${ }^{4}$. Ao mesmo tempo, indicam que um preocupante silêncio envolvia a temática em nossos bancos escolares até os anos 1990, e que o esforço para quebrá-lo seria enorme.

A partir desse quadro, o presente texto objetiva prestar uma dupla contribuição ao debate envolvendo o ensino da História da África. A primeira iniciativa será a de realizar uma espécie de mapeamento sobre o que está prescrito acerca do assunto. Ou seja, procuraremos analisar o lugar concedido à temática em parte da legislação escolar brasileira, mais especificamente a Lei $n^{\circ} 10.639 / 03$ e as diretrizes para o ensino da história africana de 2004. A segunda tarefa, pensada como complementar à primeira, mas não menos importante, será a de observar o diálogo formulado acerca da questão por alguns atentos especialistas nos estudos africanos.

\footnotetext{
${ }^{4}$ De acordo com o pesquisador Sales Augusto dos Santos, a primeira lei municipal que explicitava a obrigatoriedade do ensino da história africana nas escolas foi a Lei Orgânica do Município de Belo Horizonte, de 21 de março de 1990. No seu artigo 182, parágrafo VI, ela indica "a inclusão de conteúdo programático sobre a história da África [...]”. Já a Constituição do Estado da Bahia sinaliza apenas para "a adequação dos programas de ensino [...] à realidade histórica afro-brasileira” (Santos, 2005, pp. 26-27). De acordo com Petronilha Beatriz Gonçalves e Silva, membro do Conselho Nacional de Educação, a legislação precedente em relação à obrigatoriedade do estudo da história e cultura afro-brasileira é mais extensa, apesar também de não apresentar, na esmagadora maioria dos casos, um espaço reservado ao estudo da história africana, propriamente dita, ver CNE/CP (2004, p. 1).
} 


\section{A Lei $\mathrm{N}^{\mathrm{0}} 10.639 / 03$ e as Diretrizes Curriculares}

\section{Nacionais para a Educação das Relações Étnico-Raciais \\ e para o Ensino de História \\ e Cultura Afro-Brasileira e Africana}

Mesmo com os importantes avanços sobre o tema encontrados nos PCNs, ${ }^{5}$ o tratamento dado aos conteúdos associados aos estudos africanos continuou a ser superficial nos textos oficiais. Isso tendeu a sofrer uma clara confrontação com a promulgação da Lei Federal $n^{\circ} 10.639$, de 9 de janeiro de 2003 (que alterou a Lei no 9394/ 1996), e com o posterior parecer do Conselho Nacional de Educação (CNE/CP 03-2004, de 10.03.2004), transformado na resolução 1, de 17 de junho de 2004.

Esses documentos, frutos de uma série de inquietações e ações originadas dos movimentos negros organizados, dos interesses e apontamentos de pesquisadores e intelectuais, da análise de técnicos em educação e do comprometimento de alguns parlamentares, traçaram linhas mais claras, porém não menos insuficientes, sobre a questão. Apesar de apontarem de forma mais substanciada para possíveis temas e objetos a serem tratados nas salas de aula, os textos citados dedicam pouca atenção à África, concentrando a maioria das propostas nas questões relacionadas aos estudos da história e cultura afro-brasileiras.

A redação da Lei n ${ }^{\circ}$ 10.639/03 é sintética e direta em relação às suas determinações, ficando a tarefa de especificar ou regulamentar a temática a cargo de outras instâncias, como o Conselho Nacional de Educação. No parágrafo primeiro do artigo 26-A, ela determina o seguinte:

$\S 1^{\circ}$. O conteúdo programático a que se refere o caput deste artigo incluirá o estudo da História da África e dos Africanos, a luta dos negros no Brasil, a cultura negra brasileira e o negro na formação da sociedade nacional, resgatando a contribuição do povo negro nas áreas social, econômica e política pertinentes à História do Brasil.

\footnotetext{
${ }^{5}$ Acerca do tema ver Oliva (2007, p. 198-256).
} 
Transcorrido mais de um ano da promulgação da lei, em março de 2004, ${ }^{6}$ o Conselho Pleno do Conselho Nacional de Educação, órgão ligado ao Ministério da Educação, aprovou o parecer ${ }^{7}$ elaborado pela conselheira e relatora Petronilha Beatriz Gonçalves e Silva acerca das Diretrizes Curriculares Nacionais para a Educação das Relações Étnico-Raciais e para o Ensino de História e Cultura Afro-Brasileira e Africana, transformado em Resolução em junho daquele mesmo ano. Posteriormente, em outubro de 2004, uma publicação conjunta entre o Ministério da Educação e a Secretaria Especial de Políticas de Promoção da Igualdade Racial (SEPPIR) acabou por divulgar os elementos de regulamentação e aplicação da Lei no 10.639/03 (MEC/SEPPIR, 2004). Vejamos o tratamento concedido à história africana nesse documento.

Um primeiro aspecto a observar refere-se a um importante alerta realizado pelas Determinações das Diretrizes, no que nos pareceu ser um diálogo direto com as visões elaboradas por alguns intelectuais e teóricos africanos e afro-descendentes, associados ao movimento que o historiador guineense Carlos Lopes denominou como Corrente da Superioridade Africana (Lopes, 1995, pp. 21-29). Grande parte das leituras daqueles intelectuais defendia a inversão do foco histórico de matriz eurocêntrica, para um foco conduzido por uma matriz afrocêntrica. Os redatores do documento, parecendo conhecer as críticas e especificidades desse postulado teórico, alertam para os cuidados e os caminhos que as diretrizes curriculares deveriam seguir nas escolas.

É importante destacar que não se trata de mudar um foco etnocêntrico, marcadamente de raiz européia, por um de matriz africana, mas de ampliar o foco dos currículos escolares para a diversidade cultural, racial, social e econômica brasileira (MEC; SEPPIR, 2004, p. 17).

Dessa forma, como explicita a resolução, o "conhecimento e a valorização da história dos povos africanos" deveriam ocorrer em todos os níveis e modalidades do ensino brasileiro "como conteúdo de disci-

\footnotetext{
${ }^{6}$ A lei foi sancionada pelo Governo Federal apenas no mês de março de 2003.

${ }^{7}$ Além da relatora, participaram da elaboração do documento os seguintes conselheiros: Carlos Roberto Jamil Cury, Francisca Novantino Pinto de Ângelo e Marília Ancona-Lopez.
} 
plinas, particularmente, Educação Artística, Literatura e História do Brasil, sem prejuízo das demais" (MEC; SEPPIR, 2004, p. 18, 21). Outro importante elemento a se destacar refere-se a um aspecto até então inédito na legislação escolar: a descrição pontual de objetos e temas que deveriam ser tratados na abordagem da história africana nas salas de aulas brasileiras. No caso específico da disciplina História, os autores apontam uma extensa lista de assuntos e recortes que passam por temáticas como a tradição oral e a ancestralidade, e recobrem uma larga seleção temporal e societária, se estendendo do Egito e da Núbia antigas até a África dos dias contemporâneos. Outra ênfase encontrada nas indicações de conteúdos é a tentativa de quebrar as tendências em ler as sociedades africanas apenas pelas faces negativas do continente ou pelo grande conjunto de estereótipos que recaem sobre elas.

Em História da África, tratada em perspectiva positiva, não só de denúncia da miséria e discriminações que atingem o continente, nos tópicos pertinentes se fará articuladamente com a história dos afro-descendentes no Brasil e serão abordados temas relativos: - ao papel dos anciãos e dos griôs como guardiões da memória histórica; - à história da ancestralidade e religiosidade africana; - aos núbios e aos egípcios, como civilizações que contribuíram decisivamente para o desenvolvimento da humanidade; - às civilizações e organizações políticas pré-coloniais, como os reinos do Mali, do Congo e do Zimbábue; - ao tráfico e à escravidão do ponto de vista dos escravizados; - ao papel de europeus, de asiáticos e também de africanos no tráfico; à ocupação colonial na perspectiva dos africanos; - às lutas pela independência política dos países africanos; - às ações em prol da união africana em nossos dias, bem como o papel da União Africana, para tanto; - às relações entre as culturas e as histórias dos povos do continente africano e os da diáspora; - à formação compulsória da diáspora, vida e existência cultural e histórica dos africanos e seus descendentes fora da África; - à diversidade da diáspora, hoje, nas Américas, Caribe, Europa, Ásia; - aos acordos políticos, econômicos, educacionais e culturais entre África, Brasil e outros países da diáspora. (MEC; SEPPIR, 2004, p. 21-22).

Apesar de essa iniciativa possuir ingredientes elogiáveis, percebese também uma clara tendência em vincular o estudo da história africana ao estudo da história dos afro-descendentes. A princípio, não somos contra esse tipo de aproximação relacional, mas defendemos a idéia que eles deveriam aparecer em outro tópico, referente, por exemplo, à 
História Atlântica ou à História da Diáspora, cabendo ao estudo da História da África uma abordagem acerca da trajetória histórica do continente, em seu próprio eixo espaço-temporal.

É claro que esse recorte também incluiria as múltiplas relações mantidas com outros conjuntos civilizatórios ou sociedades, mas sempre com o foco principal na África. Além disso, por mais extensa que seja a lista, nos parece óbvio que seria impossível tratar todos os temas ou sugestões de abordagens sobre a história africana. Talvez, nesse caso, os autores pudessem ter optado por sugerir recortes temáticos, temporais e espaciais mais abrangentes, citando especificamente algumas referências apenas como exemplos possíveis. Dessa forma, o leque de assuntos seria muito maior. Já os conteúdos voltados para o estudo da cultura africana recebem um tópico próprio para sua abordagem. Nesse caso, é preciso que se destaque que as indicações representam um importante avanço para uma adequada abordagem escolar da história africana.

O ensino de Cultura Africana abrangerá: - as contribuições do Egito para a ciência e filosofia ocidentais; - as universidades africanas Timbuktu, Gao, Djene que floresciam no século XVI; - as tecnologias de agricultura, de beneficiamento de cultivos, de mineração e de edificações trazidas pelos escravizados, bem como a produção científica, artística (artes plásticas, literatura, música, dança, teatro), política, na atualidade (MEC; SEPPIR, 2004, p. 22).

Por fim, e para além das referências aos conteúdos a serem apresentados aos alunos, as Diretrizes sinalizam ainda para a necessidade de inclusão, nos cursos de formação de professores e profissionais da educação, de "materiais e de textos didáticos, na perspectiva [...]" de estimular o "ensino e aprendizagem da História e Cultura dos Afro-brasileiros e dos Africanos" (MEC; SEPPIR, 2004, p. 23). A mesma indicação é feita a outros cursos superiores no país, mesmo que não relacionados à formação de docentes ou ligados às áreas das Ciências Humanas, demonstrando a preocupação em ampliar, ao máximo, a abordagem da questão pelos bancos escolares e universitários brasileiros.

Inclusão, respeitada a autonomia dos estabelecimentos do Ensino Superior, nos conteúdos de disciplinas e em atividades curriculares dos cursos que ministra, de Educação das Relações Étnico-Raciais, de conhecimentos de ma- 
triz africana e/ou que dizem respeito à população negra. Por exemplo: em Medicina, entre outras questões, estudo da anemia falciforme, da problemática da pressão alta; em Matemática, contribuições de raiz africana, identificadas e descritas pela Etno-Matemática; em Filosofia, estudo da filosofia tradicional africana e de contribuições de filósofos africanos e afro-descendentes da atualidade (MEC; SEPPIR, 2004, p. 24).

\section{O Ensino da História Africana pela Ótica dos Especialistas}

A historiografia ${ }^{8}$ voltada para o ensino da história africana tem vivenciado um enfoque de crescente interesse, paralelo àquele presenciado pelos estudos históricos realizados sobre a África, porém em uma escala bem menor. É certo também que, para além dos textos e das reflexões realizadas pelo viés do historiador, outros especialistas - antropólogos e pedagogos, em sua maioria - também têm se dedicado a lançar questões e formular propostas acerca do tema. No entanto, se comparados às demais áreas de investigação histórica, os estudos sobre a abordagem escolar das trajetórias temporais das sociedades africanas ainda são incipientes, apesar das importantes contribuições localizadas.

No Brasil, apesar da publicação da Lei n ${ }^{\circ} 10.639 / 03$, ou talvez, motivado por ela, encontramos um quadro ainda em mudança em relação às preocupações e reflexões acadêmicas sobre o ensino da história africana. Ressalvando-se algumas exceções, foi apenas nos últimos cinco anos, às vezes um pouco antes, que nossos especialistas em estudos africanos começaram a tecer considerações mais específicas acerca do lugar da África no sistema educacional brasileiro.

Mesmo assim, tais iniciativas ainda não resultaram diretamente na produção de uma historiografia sobre o tema. Apesar disso, alguns pesquisadores, em um exercício de conversão de seus estu-

\footnotetext{
${ }^{8} \mathrm{Na}$ realidade, não é uma produção sistematizada, com grupos ou escolas articuladas em torno do tema. São reflexões, apontamentos, críticas e sugestões da historiografia africanista no Brasil acerca da questão.
} 
dos, dos objetos investigados, do acúmulo de conhecimentos e das leituras sobre a História da África, têm se esforçado para produzir textos mais sistematizados acerca da questão. Nesse caso, vamos encontrar de 2003 para cá algumas obras em formato de coletânea, ${ }^{9}$ as quais justamente se propõem a tratar a questão por vários ângulos e perspectivas, além, é claro, de alguns artigos publicados em revistas especializadas ou da área de História. Atentemos para algumas das considerações realizadas nesses espaços.

Sobre a forma como o tema foi retratado nas escolas brasileiras nos últimos anos, vamos encontrar conclusões bastante parecidas que apontam para a existência de uma grande lacuna ou para um período de intensos esquecimentos. De acordo com a historiadora Selma Pantoja, a relação do continente africano com a educação brasileira foi, durante as últimas décadas, caracterizada pela "desinformação completa" e pelo silêncio perturbador.

O silêncio diz muita coisa: historicamente, o continente é visto invariavelmente como o fornecedor de escravos. Hoje em dia urge suprir as muitas falhas referentes ao ensino da dinâmica histórica da África e das diferentes abordagens da cultura negro-africana, além das relações daquele continente com as Américas e não só com o Brasil [...]. A idéia de uma África a-histórica provocada pela colonização européia, infelizmente, ainda é predominante no nosso país (Pantoja, 2004, p. 22 e 23).

O historiador Valdemir Zamparoni também destaca os silêncios acerca da África nos bancos escolares brasileiros, resultado de uma percepção eurocêntrica e parcial da trajetória histórica da humanidade (Zamparoni, 1995, p. 515). Ainda na direção dos "esquecimentos" e das ausências africanas nos currículos escolares e no ensino da História, a historiadora Mônica Lima nos lembra do próprio alerta realizado pela promulgação da Lei n ${ }^{\circ} 10.639 / 03$. Por que a obrigatoriedade legal para inclusão de conteúdos da História da África nos currículos utilizados no Brasil? A resposta parece ser

\footnotetext{
${ }^{9}$ Ver os seguintes textos: Pantoja e Rocha (2004); Secretaria de Educação Continuada, Alfabetização e Diversidade (2005) e Munanga (1999).
} 
óbvia: o tema seria importante e teria sido por muitos anos negligenciado por programas, livros didáticos, professores e estudantes. Segundo Lima, as origens desse descaso encontrariam uma longa tradição, identificadas, por exemplo, nas posturas de alguns intelectuais brasileiros no decorrer dos dois últimos séculos.

O fato é que nossos antigos historiadores trataram indevidamente ou ignoraram a participação africana em nossa formação, influenciados por preconceitos originários da sociedade escravista, entre os quais os ideais de branqueamento da população brasileira nutridos, desde meados do século XIX, por boa parte das elites nacionais. Essa ideologia foi tão forte que mesmo a intelectualidade mais progressista custou a reconhecer a questão africana na nossa história (Mattos, 2003, p. 131).

Em contrapartida, e ainda de acordo com Lima, a renovação dos olhares lançados sobre o continente africano, fruto do trabalho de um crescente grupo de pesquisadores que tem se dedicado a investigar e refletir sobre a África, não repercutiu como deveria nos corredores universitários, e, conseqüentemente, nas salas de aulas de nossas escolas (Lima, 2004, p. 85). Essa idéia aparece reforçada pelos comentários da historiadora Hebe Maria Mattos, que destaca, justamente, o distanciamento percebido entre as prescrições programáticas expostas nos PCNs e a atividade docente em sala de aula. A crítica direciona-se para a pouca atenção concedida ao tema pelos pesquisadores universitários e, em conseqüência, para a suposta ausência da história africana nos materiais escolares (Mattos, 2004, p. 131).

Já em relação aos argumentos apresentados na justificativa ou na defesa da relevância em introduzir os estudos africanos nas escolas, vamos encontrar um conjunto mais alargado de hipóteses e teses, algumas pontuadas por elementos marcadamente historiográficos, outras, submersas em substância de aspecto mais teórico.

Nesse caso, de acordo com os especialistas, um dos motivos mais plausíveis e acertados de expor o assunto seria situá-lo numa condição de igualdade de relação com os outros conjuntos históricos, comumente estudados pelos pesquisadores e enfocados nas aulas de 
História. Ou seja, "estudar a História da África faz parte do conhecimento geral", como argumenta Selma Pantoja, é "como estudar a História da América, da Europa e da Ásia". Soma-se à tal perspectiva a necessidade de corrigir percepções distorcidas ou desequilibradas sobre o continente africano, como a perspectiva de que a História da África resume-se à história do tráfico de escravos. Para Pantoja (2004, p. 22), "se a História da África é importante para nos situar no mundo, outras faces de sua história nos revelam partes indispensáveis de nossa própria formação histórica".

Ainda no campo dos conteúdos a serem trabalhados ou (re)trabalhados nas salas de aula, Mônica Lima chama a atenção para alguns aspectos bastante similares, envolvendo sempre a redefinição do lugar ocupado pela África e pelos africanos nos estudos históricos. Se antes os africanos eram associados às imagens da escravidão, dos "dominados" e explorados, e a África era pensada como o "cenário da Expansão Colonial", a abordagem escolar adequada da história africana possibilitaria a construção de uma imagem positiva e renovada sobre os diversos contextos e circuitos históricos africanos (Lima, 2004, p. 84-85).

Os equívocos na abordagem do tráfico e da escravidão, de fato, aparecem entre alguns dos pontos mais questionados pelos historiadores, talvez porque ele seja, de fato, um dos poucos temas recorrentemente tratados em sala de aula e nos quais os africanos e a África são citados. Selma Pantoja, por exemplo, alerta para as imprecisões e incorreções aí localizadas.

O tráfico negreiro ainda é tratado de forma a ceder ao europeu o papel de único agente no comércio. [...] O mundo africano naquele momento é passado como um ambiente de constantes guerras 'tribais', tendo-se aproveitado disto os europeus. Mais grave ainda é passar a noção de que toda a população estava dispersa na floresta, e portugueses, holandeses, ingleses, etc. os caçavam jogando-os em navios negreiros (Pantoja, 2004, p. 22).

Nesse caso, seria fundamental, como destaca Mônica Lima, retirar o continente africano do espaço reflexivo marcado pelas generali- 
zações, pelos estereótipos e pelas vitimizações, e valorizar a perspectiva da África como um universo histórico-cultural diverso e complexo.

Ao mesmo tempo, é necessário despirmo-nos dos preconceitos etnocêntricos (olhar um povo ou etnia com valores de outro) - a África como lugar atrasado, inculto, selvagem - e deixar de supervalorizar o papel de vítima do tráfico, do capitalismo, do neocolonialismo -, atitude que alimenta sentimentos de impotência e incapacidade. [...] Mas há também que [...] trazer essas Áfricas para os espaços culturais e educativos, como já se tem feito, aliás. Ler, mas também escutar, ver, participar [...] (Lima, 2004, p. 85).

O historiador e antropólogo Carlos Wedderburn também defende a idéia de que, para combater uma tradição multissecular de leituras preconceituosas e, de forma mais recente, marcadamente eurocêntricas, seria preciso destacar determinados aspectos da trajetória histórica africana, com ênfase em alguns pontos fundamentais, como: o estudo das singularidades do continente - berço da humanidade, diversidade geográfica e populacional, local do desenvolvimento das primeiras civilizações - e de seus vários recortes histórico-temático-temporais (Wedderburn, 2005, p. 134-142).

Outro aspecto lembrado pelos especialistas relaciona-se à questão da construção da identidade nacional, ou melhor, do lugar da africanidade nessa identidade e no combate ao racismo. Para Lima, seria natural que as crianças tivessem dificuldades em se identificar com uma história construída por elementos e imagens carregadas de poucos valores e muitos estereótipos (Lima, 2004, p. 85).

A doutora em Psicologia e professora da Universidade de São Paulo, Ronilda Ribeiro, destaca que os estudantes que foram apresentados apenas a uma história africana marcada pelas simplificações e pelo signo da inferioridade acabaram por construir uma espécie de relação imagética com a África, a qual poderia ser simbolizada pela idéia de um "espelhado despedaçado".

[...] acreditar que 'eu venho de uma gente atrasada em relação aos outros povos do mundo' é bem diferente de saber que 'meus antepassados não viviam com o cabelo amarrado num ossinho, cozinhando brancos em caldeirões', mas integravam grandes civilizações, com magníficas arquiteturas, escrita 
própria, comércio internacional e refinadas obras de arte, faz, necessariamente, uma grande diferença (Ribeiro, 1996, p. 172).

Por fim, o último elemento a inventariar refere-se às perspectivas e propostas para incentivar ou estruturar o ensino da História da África nas escolas brasileiras. Nesse caso, os pesquisadores que se debruçaram sobre o tema buscaram construir um quadro indicativo envolvendo atividades, conteúdos e metodologias que poderiam ser articulados ao tratamento do assunto nas salas de aula.

Para Carlos Wedderburn, o trabalho com os estudos africanos só tornar-se-ia possível ou viável a partir de uma "abordagem transversal, transdisciplinar e de longa duração”, marcada por um enfoque diacrônico das trajetórias históricas das sociedades africanas e de suas relações com o mundo exterior (Wedderburn, 2005, p. 141-142). Apesar de concordar com a idéia apresentada, acreditamos que o encaminhamento sugerido por Wedderburn indique uma trilha caracterizada por uma opção teórico-analítica com limites já bastante conhecidos e debatidos em períodos anteriores.

[...] um enfoque que privilegie a interação contraditória das classes e agremiações sociais, mostrando os mecanismos internos de exploração, de dominação e coerção, assim como os conflitos decorrentes do choque de interesses variados, se revela muito mais fecundo e suscetível de refletir as realidades concretas" (Wedderburn, 2005, p. 143).

No que concerne à de uma metodologia eficiente para o ensino da história africana, Wedderburn aponta para a necessidade de se cruzarem, em uma síntese, as perspectivas metodológicas de alguns dos principais historiadores africanos, como Joseph Ki-Zerbo, Cheikh Anta Diop, Elikia M'Bokolo, Théophile Obenga, entre outros. Apesar das divergências apresentadas por esses autores, seria possível, a partir deles, o estabelecimento ou definição dos espaços civilizatórios e períodos a serem estudados.

Um dos pontos mais instigantes, e ao mesmo tempo mais densos, na proposta de Wedderburn, é a formulação bastante detalhada dos recortes históricos elencados que, separadamente, indicam algumas trilhas a serem seguidas: são quinze espaços civilizatório-políti- 
cos abordados em dez recortes cronológicos. ${ }^{10}$ Talvez, o maior problema da proposta seja a dificuldade em se construir uma visão de conjunto da história do continente. Não devemos esquecer que preservar as singularidades de suas regiões não deve ser encarado como um elemento que impeça uma possível leitura panorâmica sobre suas realidades (Wedderburn, 2005, p. 141-145). No mais, Wedderburn acredita que a melhor esquematização para se trabalhar a história africana nos ensinos fundamental e médio seria a seguinte:

Há critérios divergentes sobre como direcionar metodologicamente os estudos sobre a África, dependendo dos diferentes níveis de ensino. Para muitos, é necessário manter um enfoque linear-factual [...] para níveis correspondentes ao ensino fundamental. [...] O ensino médio é a porta de entrada para o mundo acadêmico, portanto se espera que nesse nível a história africana já seja abordada de forma complexa (Wedderburn, 2005, p. 143).

Nesse sentido, uma outra perspectiva possível é apontada por Selma Pantoja, que defende a tendência de se estudar a História da África de "maneira global e não parcelar". O risco de estudar a África "em porções" seria o de preservar um conjunto de idéias e imagens que projetam um continente longínquo. Já sobre os conteúdos que poderiam ser abordados, a historiadora aponta, entre outros temas, para a questão da "anterioridade africana" e as relações ativas dos africanos com os oceanos e outras partes do mundo. Para além dessas indicações, Pantoja afirma que outro elemento central nas transformações esperadas acerca da abordagem escolar da história africana seria a necessidade de ampliar a "formação de professores e pesquisadores africanistas", seguida da ampliação da oferta de disci-

\footnotetext{
${ }^{10}$ Os espaços civilizatório-políticos seriam os seguintes: núbio-egípcio-kushita; etíope-somálio-axumita; ugando-ruando-burundês; tanzano-queniano-zairiano; zimbábuo-moçambicano; botswano-azaniano; madagasco-comoriense; namíbio-zambiano; congo-angolano; nígero-camaronês; ganeano-burkino-marfinense; senegalo-guineo-maliense; mauritano-saeliano; marroco-numídio-cartaginês; chado-líbio. Já os recortes cronológicos seriam estes: Antigüidade Pré-Histórica; Antigüidade Remota I; Antigüidade Remota II; Antigüidade Remota III; Antigüidade Próxima; Antigüidade Clássica; Antigüidade Neoclássica; Período Ressurgente; Período Colonial e Período Contemporâneo, ver Wedderburn (2005, p. 146-152).
} 
plinas envolvendo estudos africanos nas universidades e, conseqüentemente, aumento do número de professores capacitados para trabalhar com a temática nas escolas (Pantoja, 2004, p. 22).

Por fim, Mônica Lima discute um conjunto mais detalhado de procedimentos e temas que poderiam propiciar um tratamento adequado à questão. A preocupação com a formação dos professores, já apontada anteriormente, também freqüenta suas sugestões, em um sentido mais de reivindicação dos segmentos envolvidos com a educação do que de livre iniciativa do Estado e instituições competentes para tal. Nesse caso, sua indicação gira em torno da necessidade de estudantes exigirem a "inclusão efetiva desses assuntos nos currículos de suas faculdades" e de professores na ativa solicitarem cursos de qualificação sobre a temática. Em todos os casos, a organização de grupos de estudo e pesquisa poderia também minimizar as defasagens encontradas em suas formações profissionais (Lima, 2004, p. 85-86).

E, independentemente da qualificação em estudos africanos, já seria possível aos docentes trilhar alguns caminhos considerados positivos sobre o tema. Para a primeira parte do Ensino Fundamental, Lima sugere o trabalho com "lendas, contos, cantigas, brincadeiras"; já para as séries finais, a indicação seria o estudo do "processo de humanização", "o esplendor do Antigo Egito" e dos "grandes reinos africanos". Para o Ensino Médio, as idéias a serem tratadas girariam em torno do racismo, do processo de ocupação colonial e da África contemporânea (Lima, 2004, p. 86).

\section{Considerações Finais}

Encontramos um quadro que aponta para um panorama de mudanças no Brasil no que diz respeito ao ensino da história africana. Ao mesmo tempo em que a legislação específica sobre a inclusão dessa temática nas escolas brasileiras possa ser considerada um avanço no campo da prescrição, ela sinaliza para a evidente constatação de que, até o 
final dos anos 1990, com raríssimas exceções, o continente africano se encontrava a uma distância oceânica dos estudantes brasileiros.

Ao mesmo tempo, presenciamos, nos últimos anos, muitas iniciativas que possuíam como objetivo principal promover o debate e divulgar experiências de como abordar o assunto nas salas de aula. Nesse sentido, procuramos aqui destacar as falas de alguns de nossos especialistas na história africana, quando seus olhares se direcionaram para o exercício de estudar a África nas séries da educação básica. De certa forma, e apesar de algumas trilhas em comum, percebemos que entre a prescrição legal e a vivência no campo do real a trajetória a ser percorrida é longa e cheia de obstáculos. No entanto, os tempos vividos são otimistas e, se a tendência de mudanças se confirmar, nossas futuras gerações terão novas e positivas imagens sobre o continente que nos toca pela fronteira do Atlântico sul.

\section{Referências}

CONSELHO NACIONAL DE EDUCAÇÃO. Diretrizes Curriculares Nacionais para a Educação das Relações Étnico-Raciais e para o Ensino de História e Cultura Afro-Brasileira e Africana. Parecer n 003 de 2004, de 10 de março de 2004. LIMA, Mônica. A África na Sala de Aula. Nossa História, ano 1, n 4, fevereiro de 2004.

LOPES, Carlos. A Pirâmide Invertida - historiografia africana feita por africanos. In Actas do Colóquio Construção e Ensino da História da África. Lisboa: Linopazas, 1995, p. 21-29.

MACEDO, José Rivair; OLIVEIRA, Mariley W. Uma história em construção, vol. 3. São Paulo: Editora do Brasil, 1999.

MARANHÃO, Ricardo; ANTUNES, Maria Fernanda. Trabalho e Civilização: uma história global, 2. São Paulo: Moderna, 1999.

MATTOS, Hebe Maria. O Ensino de História e a luta contra a discriminação racial no Brasil. In: Martha ABREU \& Rachel SOIHET. Ensino de História: conceitos, temáticas e metodologia. Rio de Janeiro: Casa da Palavra; FAPERJ, 2003. 
MINISTÉRIO DA EDUCAÇÃO; SECRETARIA ESPECIAL DE POLÍTICAS DE PROMOÇÃO DA IGUALDADE RACIAL. Diretrizes Curriculares Nacionais para a Educação das Relaçoes Étnico-Raciais e para o Ensino de História e Cultura Afro-Brasileira e Africana. Brasilia: MEC, 2004.

MUNANGA, Kabengele (Org.) Superando o racismo na escola. Brasília: Ministério da Educação/Secretaria de Educação Fundamental, 2001.

OLIVA, Anderson Ribeiro. Lições sobre a África: diálogos entre as representações dos africanos no imaginário ocidental e o ensino da História da África no Mundo Atlântico (1990-2005). Universidade de Brasília: Instituto de Ciências Humanas, Tese de Doutorado, 2007.

. A história africana nos cursos de formação de professores: panorama, perspectivas e experiências. In: Estudos Afro-Asiáticos, v. 28, p. 187-219, 2006.

PANTOJA, Selma. A África imaginada e a África real. In Selma PANTOJA \& Maria José ROCHA (Org.). Rompendo Silêncios: História da África nos currículos da educação básica. Brasília: DP Comunicações, 2004, p. 22-23.

RIBEIRO, Ronilda. Ação educacional na construção do novo imaginário infantil sobre a África. In: Kabengele MUNANGA (Org.). Estratégias e políticas de combate à discriminação racial. São Paulo: EDUSP; Estação Ciência, 1996, p. 167-176.

SANTOS, Sales Augusto. A Lei no 10.639 como fruto da luta anti-racista do movimento negro. In: SECRETARIA DE EDUCAÇÃO CONTINUADA, ALFABETIZAÇÃO E DIVERSIDADE. Educação Anti-racista: caminhos abertos pela Lei Federal 10.639/03. Brasilia, MEC; Secad, p. 21-37, 2005.

SCHMIDT, Mario. Nova História Crítica, 6ª série. São Paulo: Nova Geração, 2002. SECRETARIA DE EDUCAÇÃO CONTINUADA, ALFABETIZAÇÃO E DIVERSIDADE. Educação Anti-racista: caminhos abertos pela Lei Federal 10.639/03. Brasília, MEC; SECAD, 2005.

SECRETARIA DE EDUCAÇÃO FUNDAMENTAL. Parâmetros Curriculares Nacionais. História. Brasília: MEC/SEF, 1998.

WEDDERBURN, Carlos Moore. Novas bases para o Ensino da História da África no Brasil. In: SECRETARIA DE EDUCAÇÃO CONTINUADA, ALFABETIZAÇÃO E DIVERSIDADE Educação Anti-racista: caminhos abertos pela Lei Federal 10.639/03. Brasilia: MEC-SECAD, 2005, pp. 133-166.

ZAMPARONI, Valdemir. A situação atual dos estudos africanos no Brasil. In: Actas do Colóquio Construção e Ensino da História da Africa. Lisboa: Linopazas, 1995. 


\section{5 \\ O ENSINO DE HISTÓRIA DA ÁFRICA: EXPERIÊNCIAS A PARTIR DA SALA DE AULA}

\section{Marisa Antunes Laureano}

Em 9 de janeiro de 2003, o presidente da República sancionou uma lei que movimentou os debates relacionados a questões étnicoraciais. Foi firmada uma conquista do movimento negro, que havia décadas lutava por uma valorização das origens étnicas do povo negro brasileiro. Nada se dizia; nada se fazia; nada era exposto de forma ampla quando se tratava do estudo da História da África e da Cultura afrobrasileira. As produções acadêmicas, os trabalhos pedagógicos não se aproximavam das escolas e, portanto, não traziam resultados que representassem mudanças na forma de se ver e pensar o negro no Brasil.

Atualmente, um grande número de professores tem procurado informação para ampliar seus conhecimentos e poder aplicar a lei em sua escola ou em sua sala de aula. Para tanto, são necessários apoio e incentivo para que não desanimem e continuem este processo, que inicia a introdução do ensino de História da África e da cultura afrobrasileira nos currículos escolares. Visando incentivar, encaminho alguns pontos de uma experiência de trabalho com turmas do Ensino Médio e Fundamental de escola pública do Rio Grande do Sul.

\section{O Professor e o Conhecimento sobre História da África}

Trabalhar um conteúdo novo no currículo escolar é difícil tanto para os professores quanto para os alunos. Mesmo que o aluno não tenha amplo conhecimento sobre quais conteúdos competem a sua série ou ciclo, há sempre um entrave inicial. Muito pela novidade di- 
ante do que eles ouviram falar e pela insegurança que o professor irá ter ao apresentar determinado assunto.

Quando verificamos a necessidade de mudança, somos nós, os professores, os primeiros a reagir com insegurança e medo. Como muito já foi dito, o novo dá medo, o que não se pode é permitir que o aluno perceba isso. O professor deve mostrar segurança sempre, mesmo naqueles assuntos que não domina totalmente. Para isso, a pesquisa é fundamental. Dominar com segurança, mesmo que uma parte do conteúdo proposto para o trabalho, já garante alguns resultados positivos.

Quando nos referimos à História da África, o assunto torna-se mais complexo por vários motivos:

1. É um conteúdo que o professor não viu na universidade.

2. O material para estudo de tal conteúdo é recente (e agora caro).

3. As compilações apresentadas não aprofundam algumas temáticas, o que não traz segurança aos professores.

4. Os cursos oferecidos não são acessíveis a todos os professores, principalmente de escola pública, pois esbarram no tempo, dinheiro e acesso à internet que muitos professores não têm.

5. E há também o convencimento da importância de tal conteúdo tanto para a classe como para os colegas.

Não é necessário elaborar muitas outras questões que nos levam ao entrave e à desistência para abrirmos para o novo e mudarmos de vez o currículo escolar. O que me compete agora é elucidar alguns caminhos que driblem essas dificuldades e nos tragam algumas saídas.

Os cursos de formação de professores de História atualmente não dão ênfase à História da África, relegando tal conteúdo às disciplinas opcionais raramente oferecidas. Diante de tal desinteresse acadêmico em munir o futuro professor com conhecimentos necessários para o ensino de História da África, nos deparamos com profissionais com vontade, mas sem a base necessária para aplicar um bom 
projeto em sala de aula. Frente a tal carência, os verdadeiramente interessados correram atrás de uma formação de extensão. Os demais foram pegos de surpresa pela Lei $\mathrm{n}^{\circ} 10.639 / 03$ e preferem ignorar tal lei. Existem ainda situações em que o professor é cobrado para que faça cumprir a lei e, para tanto, ele tem que desvendar o desconhecido: a História da África.

Para compensar a defasagem, é necessário um investimento do professor. Comprar um bom manual é indispensável para um entendimento melhor sobre o assunto e possibilitar um caminho de segurança quando a abordagem for feita em sala de aula. Ficar restrito aos livros didáticos pode levar o professor a erros e a questionamentos sem resposta. Os livros didáticos não são completos para estudarmos a História da África, e o professor deve sempre ir além desse recurso. A grande insegurança do professor ocorre justamente por ter por base apenas os livros do aluno, o que vai resultar em desconhecimento do que deveria ser a contribuição que o professor daria em aula. Em trabalho recente, Anderson Oliva, pesquisador de livros didáticos sobre História da África, diz o seguinte:

Silêncio e desconhecimento. Poderíamos assim definir o entendimento e a utilização da História da África nas coleções escolares de História no Brasil. Apenas um número muito pequeno de livros possui capítulos específicos sobre a História da África. Nas outras obras, a África aparece apenas como uma figurante que passa despercebida em cena, sendo mencionada como um apêndice misterioso e pouco interessante de outras temáticas. Tornou-se evidente também que, quando o silêncio é quebrado, a formação inadequada e a bibliografia limitada criam obstáculos significativos para uma leitura mais atenta e um tratamento mais pontual sobre a questão.

[...] quase sempre, a África aparece em óbvias passagens da História do Brasil, da América ou da Europa, ligadas à escravidão, à expansão ultramarina, ao domínio colonial no século XIX, ao processo de independência e às graves crises sociais, étnicas, econômicas e políticas em que mergulhou grande parte dos países africanos formados no século XX (Oliva, 2003, p. 429).

Assim, posso reafirmar que, diante de poucas abordagens corretas sobre a História da África nos livros didáticos, estes não seriam o manual ideal para o professor, já que até para os alunos são falhos. 
Existem alguns bons manuais acessíveis em preço aos professores para que tenham uma base em seu planejamento de aula sobre a História da África, destacando-se que a partir de 2005 os livros sobre a África inflacionaram e alguns já estão esgotados.

Atualmente, o MEC está colocando à disposição das escolas muito material bom para pesquisa sobre o ensino de História da África. Dentre esses materiais, indico Educação, Africanidades, Brasil - coordenação de Glória Moura, Centro de Educação à Distância (CEAD/UNB), Brasília, DF, 2006. Este livro reuniu vários textos de diversos autores que tratam de ensino, história e geografia voltados ao trabalho do professor em sala de aula. Outro livro importante é o de Marina de Mello e Silva - África e Brasil africano - São Paulo: Ática, 2006. Trata-se de um manual de fácil leitura muito bem organizado, que vai desde a África antiga até o Brasil africano, ou seja, o Brasil em relação à África, suas heranças e a importância na formação de nossa cultura. Já Nelson Bacic Olic e Beatriz Canepa - Africa, Terra e Sociedade - São Paulo: Moderna, 2004, Coleção Polêmica, apresentam um paradidático que traz informações úteis para o professor e o aluno sobre a geografia africana. Para trabalhar com o aluno, indico o livro, também paradidático, de Isimeme Ibazebo - Explorando a África - tradução de Isa Mara Lando - São Paulo: Editora Ática, 1997. Ele contém um breve histórico sobre os relatos dos viajantes que percorreram o território africano. Ainda para trabalhar com os alunos, recomendo o paradidático de Roberto Emerson Câmara Benjamin - $A$ Africa está em nós: história e cultura afro-brasileira - João Pessoa, PB: Editora Grafset, 2004, que trata mais das heranças africanas no Brasil, mas é importante para realização de um projeto sobre História da África que, de alguma maneira, irá culminar em nossas heranças.

Assim que alguns professores começarem a buscar o conhecimento vão estar na condição de multiplicadores. Eu aprendo e, a partir do meu conhecimento, vou trabalhar com meu colega que irá aprender também e assim por diante. A multiplicação iniciará uma quebra na resistência dos colegas em iniciarem os estudos e trabalharem a temática em sala de aula. 


\section{Possibilidade de Trabalho}

\section{a Partir da Sala de Aula no Ensino Fundamental}

Quando a idéia é trabalhar a cultura afro-brasileira, tem-se uma gama de exemplos, de projetos, de professores que fazem atividades as mais diversas relacionadas ao tema. Entretanto, devemos atender à determinação da lei da introdução da História da África por um motivo bem claro: não se muda preconceito sem ir à origem dele e apresentar um outro conceito para que determinados grupos criem novas visões de mundo. A cultura afro-brasileira é de suma importância para inclusão e melhor visão sobre a importância das negras e dos negros deste país. Mas devemos antes salientar a origem destes homens e mulheres, destacando de antemão o que foi e o que é a África. Muito do preconceito com relação à origem do povo negro brasileiro é em função do conceito que fazem da África. Um lugar de onde descende um povo miserável, sem cultura, sujeito a doenças, e de fácil dominio. E o que se pode destacar, fora esses conceitos, é o exotismo tanto em natureza quanto em povos, a maioria tribais e primitivos. Esse tipo de pensamento permeia as relações sociais entre negros e brancos no Brasil há muitos séculos. É justamente contra essa idéia errônea de África que devemos lutar. O conhecimento sobre um Continente grandioso de muitos povos distintos e culturas diversas, que é a África, deve ser apresentado de forma a dar clareza sobre a história há muito negada do continente africano.

Quando iniciamos uma proposta de trabalho sobre a História da África, enfrentamos algumas dificuldades iniciais de estranhamento. Por isso, proponho que o trabalho seja feito através de projeto. Se apenas incluirmos o tema África nos planos de aula, introduzindo o assunto apenas como seqüência ao conteúdo predeterminado, corremos um risco ainda maior de perdermos o caminho, de não conseguirmos dar conta como deveria, ou esperaríamos do tema. Será só mais um assunto maçante para os alunos que tenderão a rejeitá-lo, ocasionando uma dupla decepção: aos alunos e ao professor. 
Um projeto com todas as possibilidades descritas e avaliadas antecipadamente não garante sucesso absoluto, mas gera alguns caminhos mais seguros para o desenvolvimento do trabalho. Apresento um exemplo de projeto que realizei com turmas de $5^{a}$ série do Ensino Fundamental e que trouxe resultados positivos quanto ao ensino de História da África. Não podemos, também, imaginar que aquilo que está descrito no texto do projeto venha se concretizar tal como ali está, visto que contamos sempre com o inesperado e é isso o que justamente torna a profissão de professor interessante. Porém, muito da viabilidade do trabalho ocorreu pela organização e projeção de tarefas e resultados esperados.

O trabalho tinha que ser dividido entre os alunos de cinco turmas de $5^{a}$ série com uma média de quarenta alunos em cada turma. Para que houvesse condições de avaliação adequada e acompanhamento, os alunos foram divididos em grupos. Cada turma foi dividida em grupos de cinco pessoas. Com os grupos formados, os alunos tiveram algumas aulas sobre História da África Antiga.

Tratou-se de África Antiga, por ser conteúdo do currículo da $5^{a}$ Série o Egito Antigo. Partindo do Egito, segui com a África dando destaque a outras sociedades antigas da costa oriental do continente africano. Depois de dada essa exposição, em algumas aulas, os alunos passaram a trabalhar nos grupos com livros e diversos materiais coletados para que eles pesquisassem um pouco sobre a África em sala de aula. O tempo de trabalho de pesquisa sobre a África foi estabelecido no projeto. Na aula seguinte à pesquisa, os alunos receberam o nome de um país africano (feito por sorteio), sobre o qual eles teriam que pesquisar e apresentar o resultado da pesquisa em um trabalho escrito e de exposição. Para organizar essa etapa, cada grupo teria que fazer seu projeto no qual constariam:

- O nome do país.

- A região da África onde estava localizado.

- Onde poderiam fazer a pesquisa sobre o país. 
- Que tipo de trabalho o grupo faria para expor.

A partir daí, os membros do grupo teriam que trabalhar em busca do seu próprio conhecimento. Os dois encontros seguintes foram dedicados à reunião do grupo e à organização do trabalho. No terceiro encontro, eles tiveram que apresentar por escrito como estava o andamento do trabalho, o que já haviam conseguido para o trabalho escrito (se não haviam conseguido nada deveriam pedir ajuda à professora) e quais materiais utilizariam para construir o seu trabalho de exposição. A surpresa maior nesta etapa foi a pesquisa na internet. Por ser uma escola de região muito carente, pensei que eles teriam dificuldades para usar esta ferramenta, mas não. Foram atrás e pelo menos um em cada grupo conseguiu pesquisar na internet. A maioria decidiu fazer maquete sobre o país, outros iriam fazer cartazes e poucos quiseram apresentar o trabalho escrito. Um grupo quis fazer dança e outro, comida. O resultado de todo este trabalho que durou dois meses foi um aprendizado conjunto, pois eu aprendi, eles aprenderam e tiveram a oportunidade de demonstrar este conhecimento para os colegas de outras séries.

$\mathrm{O}$ meu cuidado maior quando penso em um trabalho sobre a África é realmente mostrar a África, ou seja, quais são as características africanas e as relações que podemos fazer de lá para cá. A grande maioria dos projetos que tenho acompanhado apresenta-se como História da África e trata apenas da cultura afro-brasileira. Vamos fazer comida típica africana e logo aparece a canjica (mungunzá), a pamonha, a feijoada, e outros tantos pratos tipicamente brasileiros. Os africanos que aqui chegaram tiveram que adaptar a sua culinária ao que podiam encontrar aqui. O arroz era muito utilizado na África para vários pratos, que aqui foram substituídos pelo milho. Devemos conhecer a África e conhecer o Brasil e a partir daí fazer a relação. Dar destaque, é claro, ao fato de que tudo isso é uma herança do Continente Africano, e, como herança, modificado, alterado, adaptado e até enriquecido e preservado, legando ao presente até culturas que já não existem na África. 
Voltando ao projeto do Ensino Fundamental, ocorreram duas situações que marcaram o final destes trabalhos:

- Uma aluna entregou-me um desenho (ato comum para os alunos de $5^{a}$ série). A diferença é que o desenho era de Iemanjá me desejando muita felicidade. As crianças tendem a esconder sua crença quando se trata de religião afro-brasileira.

- Um menino, ao ser perguntado sobre qual era sua religião, disse em voz bem alta: "Eu sou da religião da minha mãe, da minha vó e dos meus antepassados que vieram da África".

Foi interessante que esbarrei no preconceito dos pais diante de tal trabalho. Muitas crianças vieram com comentários preconceituosos sobre a África e seus habitantes e iniciavam suas frases dizendo "minha mãe disse" ou "meu pai disse". Tive que tentar mudar o pensamento das crianças e para que, talvez, refletisse nos pais. Um grupo que colocou a frase dos pais disse que, na África, só existiam miséria e pobreza e não tinha nada que elas poderiam apresentar. Algumas meninas disseram que a mãe lhe havia mandado ficar pulando e gritando e assim estariam representando a África. Devemos nos preparar para discutir o preconceito e reverter a situação, já que todo o projeto visa justamente a isso.

\section{Possibilidade de Trabalho \\ a Partir da Sala de Aula no Ensino Médio}

O grande desafio ao introduzir História da África é no Ensino Médio. Existe ainda certa resistência de nossa parte em propor projetos de trabalho para alunos do Ensino Médio. Pensamos logo que não serão realizados, que o aluno não irá fazer, e a clássica afirmação: "o aluno não quer nada com nada". Porém, dará mais errado ainda a simples inclusão de História da África se não houver algo 
muito bem planejado antes. O aluno do Ensino Médio já vem com um currículo pronto em sua idéia e mudá-lo é mais difícil. E contamos com o fato que ele nunca viu nada referente à História da África em sua vida escolar.

Introduzi História da África no conteúdo do $2^{\circ}$ ano do Ensino Médio. Uma turma apenas estava seguindo o andamento do conteúdo e outra com plano de trabalho específico para História da África. Na primeira, o retorno foi muito ruim. Os alunos pareciam já saber tudo sobre África e não se mostraram dispostos a mudar seus conceitos. Ao esbarrar na primeira dificuldade, estabeleci outra abordagem para a turma seguinte. Não elaborei um projeto como para o fundamental, mas, sim, um plano de trabalho no qual parti do conhecimento deles e fui desmistificando a África que eles pensavam conhecer. Eles, primeiro sem ouvir nada de mim sobre a África, tiveram que redigir um texto sobre a visão que tinham da África. Saiu o que eu já esperava, com apenas uma exceção. Textos como estes:

$R=$ sbfica éum continenfe conshiturdo por paises muito pobres, subdesenvoluidos, a quivia de papulacea noilo pobre é uma regiäo cam relevo peedomonanto por sovemas, evisten seluas ole con animois ferazes, éa masor produtor dédicmente mas apesar Jiso a fome, miseŕa e doencas imperam no maisrra das regiés

Tey un povo basicamente rusal, säo sepacadas por tribos algumas bastonle evóticas, com uma cultura muito diferencic. de da nossa.

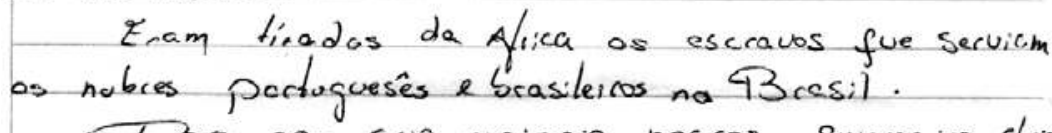
de crencas e facca. 

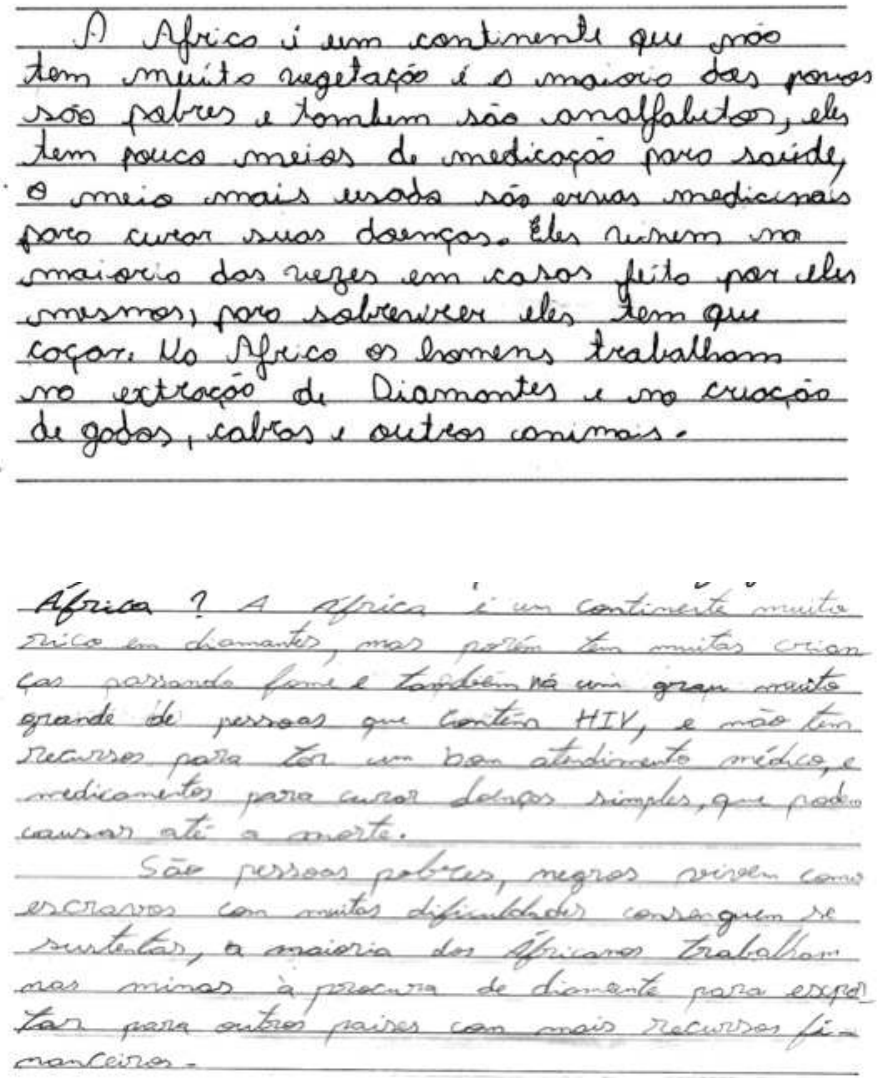

Vejam que os textos se equiparam em visão e demonstram um senso comum sobre a África muito conhecido de todos. O filme Diamante de Sangue (Dir. Edward Zwick, 2006) pautou muito dos escritos dos alunos. E com um detalhe importante: a maioria deles não havia assistido ao filme.

A partir desses textos, as aulas foram seguindo o caminho de desmistificar muito desses conceitos apresentados e colocando todos os países da África em seu devido status social, econômico e cultural. Houve muitas surpresas, descrenças e questionamento sobre o 
porquê de a televisão só mostrar aquela África descrita por eles. A turma foi movimentada, o que enriqueceu a discussão e trouxe os alunos para mais perto do tema.

\section{Considerações Finais}

A Lei no 10.639/03 é o resultado de uma luta histórica. O movimento negro e todas as entidades que combatem o racismo e a discriminação racial, de qualquer natureza, reconhecem que essas práticas discriminatórias são frutos do desconhecimento $\mathrm{O}$ povo negro sofre preconceito há séculos, e somente o conhecimento da História e de uma compreensão de sua cultura irá encaminhar a nossa sociedade para o rompimento com práticas preconceituosas e discriminatórias.

Essa lei, quando criada, abriu um espaço para debates, pesquisas e publicações sobre a África nos mais diversos aspectos. Entretanto, esse espaço ainda é pequeno diante da importância do tema para a sociedade brasileira. Os caminhos investigativos, portanto, direcionam para um olhar próprio sobre um objeto pouco trabalhado, qual seja, o das representações sobre a África através da ótica dos professores que se propõem a um projeto de ensino sobre este tema.

\section{Referências}

ABREU, Martha \& SOIHET, Rachel (Org.). Ensino de Historia: Conceitos, temáticas e metodologia. Rio de Janeiro: Casa da Palavra, 2003.

BENJAMIN, Roberto Emerson Câmara. A Africa está em nós: história e cultura afro-brasileira. João Pessoa, PB: Editora Grafset, 2004.

BOTO, Carlota. A civilização escolar como projeto político e pedagógico da modernidade: cultura em classes, por escrito. Cadernos CEDES (Campinas) vol. 23 n 61,2003 , p. 378-397 (Disponível on-line: www.cedes.unicamp.br)

HENRIQUES, Ricardo. Raça e gênero no sistema de ensino: os limites das políticas universalistas na educação. Brasília: UNESCO, 2002. 
IBAZEBO, Isimeme. Explorando a África. Trad. de Isa Mara Lando. São Paulo: Editora Ática, 1997.

KARNAL, Leandro (Org.). História na sala de aula: conceitos, práticas e propostas. São Paulo: Contexto, 2004.

MELLO E SILVA, Marina de. África e Brasil africano. São Paulo: Ed. Ática, 2006.

MOURA, Glória (Coord.). Educação, Africanidades, Brasil. Brasília: Centro de Educação à Distância (CEAD/UNB), 2006.

OLIC, Nelson Bacic \& CANEPA, Beatriz. África, terra e sociedade. São Paulo: Ed. Moderna, 2004. Coleção Polêmica.

OLIVA, Anderson Ribeiro. A História da África nos bancos escolares. Representações e imprecisões na literatura didática. Estudos Afro-asiáticos (Rio de Janeiro) vol. 25, n 3, 2003 (Disponível on-line em: www.casadasafricas.org.br).

PINGUILLY, Yves. Contos e lendas da África. Trad. de Eduardo Brandão. São Paulo: Companhia das Letras, 2005.

SANTOS, Gevanilda \& SILVA, Maria Palmira da (Org.). Racismo no Brasil: percepções da discriminação e do preconceito no século XXI. São Paulo: Editora Fundação Perseu Abramo, 2005.

SARAIVA, José Flávio Sombra. Formação da África Contemporânea. São Paulo: Ed. Atual, 1987.

SERRANO, Carlos. O processo de constituição dos Estados Nacionais e as Questões Culturais. In: Países africanos de lingua oficial portuguesa: reflexões sobre história, desenvolvimento e administração. Seminários FUNDAP, 1991. 


\section{OUTRAS REFERÊNCIAS SOBRE HISTÓRIA AFRICANA}

\section{Livros em Língua Portuguesa}

ACTAS DO COLÓQUIO. A construção e ensino da História de África. Lisboa: Linopazas, 1995.

AMARAL, Ilídio. O Reino do Congo, os mbundu (ou ambundos), o reino dos Ngola e a presença portuguesa de finais do século XV a meados do século XVI. Lisboa: I.I.C.T., 1996.

ANDRADE, António Alberto de. História breve da Guinéportuguesa. Lisboa, 1968. APPIAH, Kwame Anthony. Na casa de meu pai. A África na filosofia da cultura. Rio de Janeiro: Editora Contraponto, 1997.

AREIA, M. L. Rodrigues \& MIRANDA, M.A. (orgs). Perspectivas sobre Angola. Coimbra: Departamento de Antropologia - Universidade de Coimbra, 2001.

AZIZ, Philippe. Os impérios negros da Idade Média (Coleção Grandes Civilizações Desaparecidas). Rio de Janeiro: Otto Pierre Editores, 1978.

BALLONG, J. Bato’ora. São Jorge da Mina. 1482-1637. Lisboa: Fundação Calouste Gulbenkian, 1993.

BELLUCCI, Beluce (Coord.). Introdução à bistória da África e da cultura afrobrasileira. Rio de Janeiro: CCBB/RJ e CEAA/UCAM, 2003.

BENJAMIN, Roberto Emerson Câmara. A África está em nós: história e cultura afro-brasileira. João Pessoa, PB: Editora Grafset, 2004.

BIRMINGHAM, David. A África central até 1870. Luanda: ENDIPU/ UEE, 1992.

BOAVIDA, Américo. Angola: cinco séculos de exploração portuguesa. Rio de Janeiro: Ed. Civilização Brasileira, 1967.

BORGES, Edson. Moçambique: cultura e racismo no país do Índico. Rio de Janeiro: Academia da Latinidade, 2001.

BRAVO, Manuel. Angola: transição para a paz, reconciliação e desenvolvimento. Lisboa: Ed. Hugin, 1996.

BRUNSCHWIG, Henri. A partilha da África. São Paulo: Ed. Perspectiva, 2004.

CALDEIRA, Arlindo Manuel. Mulheres, sexualidade e casamento em São Tomé e Príncipe (séculos XV-XVIII). Lisboa: Edições Cosmos, 1999. 
CAPELA, José. O escravismo colonial em Moçambique. Porto: Ed. Afrontamento, 1993.

CASCUDO, Luis Câmara. Made in África. São Paulo: Global, 2001.

CHATWIN, Bruce. O vice-rei de Uidá. São Paulo. Companhia das Letras, 1989. COQUERY-VIDROVITCH, Catherine (org). A descoberta de África. Lisboa: Edições 70, 1981.

CORNEVIN, Marianne. História da África contemporânea: da Segunda Guerra aos nossos dias. Lisboa: Ed. Sociais, 1979.

COSTA E SILVA, Alberto da. A enxada e a lança: a África antes dos portugueses. Rio de Janeiro: Ed. Nova Fronteira, 1996.

- A manilha e o libambo: a África e a escravidão. Rio de Janeiro: Nova Fronteira, 2002.

. Um rio chamado Atlântico: a África no Brasil e o Brasil na África. Rio de Janeiro: Ed. Nova Fronteira, 2003.

CUNHA, Manuela Carneiro da. Negros, estrangeiros: os escravos libertos e sua volta à África. São Paulo: Brasiliense, 1985.

CURTO, José C.. Álcool e escravos: o comércio luso-brasileiro do álcool. Mpínda, Luanda e Benguela (1480-1830). Lisboa: Ed. Vulgata, 2002.

DAVIDSON, Basil. Os africanos. Uma introdução à sua história cultural. Lisboa: Edições 70, 1969.

. Revelando a Velha Africa. Lisboa: Ed. Prelo, 1977. . Angola. Lisboa: Delfos, 1974.

. Mãe negra África: os anos de provação. Lisboa: Sá da Costa: Luanda: Ministério da Educação da República Popular de Angola, 1981.

DIAS, Jill R.. África. Nas vésperas do mundo moderno. Lisboa: Comemorações dos Descobrimentos Portugueses, 1992.

DUMONT, René. A África começa mal. Lisboa: Publicações Dom Quixote, 1962.

ENDERS, Armelle. História da África lusófona. Mem-Martins: Inquérito, 1997.

EVANS-PRITCHARD, E.E.. Os nuer: uma descrição do modo de subsistência e das instituições políticas de um grupo nilótico. São Paulo: Ed. Perspectiva, 2002 (org. 1976).

. Bruxaria, oráculos e magia entre os Azande. Rio de Janeiro: Zahar, 1976.

FAGAN, Briam. África Austral. Lisboa: Editorial Vervo, 1972. 
FAGE, John \& OLIVER, Roland. Breve História da África. Lisboa: Sá da Costa, 1980.

. História da Africa. Lisboa: Edições 70, 1997.

FERNANDES, Gabriel. A diluição da Africa. Florianópolis: EdUFSC, 2002. FERRONHA, António Luís Alves. As cartas do "rei" do Congo D. Afonso. (Introdução, notas, comentário e modernização do texto) Lisboa: Grupo de Trabalho do Ministério da Educação para as Comemorações dos Descobrimentos Portugueses, 1992.

. O monomotapa (Introdução, notas, comentário e modernização do texto). Lisboa: Grupo de Trabalho do Ministério da Educação para as Comemorações dos Descobrimentos Portugueses, 1994.

FORTES, M. \& EVANS-PRITCHARD, E. E.. Sistemas políticos africanos. Lisboa: Fundação Calouste Gulbenkian, 1983.

GILROY, Paul. O Atlântico negro: modernidade e dupla consciência. Rio de Janeiro: Universidade Cândido Mendes/Editora 34, 2001.

GIORDANI, Mário Curtis. História da Africa - Anterior aos descobrimentos - Idade Moderna. Petrópolis: Ed. Vozes, 1985.

GUIMARÃES, Samuel (Org.). Africa do Sul: visões brasileiras. Brasillia: IPRI/ FUNAG, 2000.

GURAN, Milton. Agudas - os "brasileiros" do Benim. Rio de Janeiro: Ed. Nova Fronteira, 2000.

HAMPATÊ BÂ, Amadou. Amkoullel, o menino fula. São Paulo: Palas Athena: Casa das Áfricas, 2003.

HENRIQUES, Isabel Castro. São Tomé e Príncipe. A invenção de uma sociedade. Lisboa: Ed. Vega, 2000.

HERNANDEZ, Leila Leite. A África na sala de aula. São Paulo: Selo Negro Edições, 2005.

- Os filhos da terra do sol: a formação do Estado-Nação em Cabo Verde. São Paulo: Summus/Selo Negro, 2002.

IBAZEBO, Isimeme. Explorando a África. Trad. Isa Mara Lando. São Paulo: Editora Ática, 1997.

ILIFFE, John. Os africanos: história de um continente. Lisboa: Ed. Terramar, 1999.

KI-ZERBO, Joseph. História da África Negra. Mem-Martins: Publicações Europa-América, s.d., 2 vols. 
LESSA, Clado Ribeiro de (Ed.). Viagem de África em o Reino de Dabomé, escrita pelo Pe. Vicente Ferreira Pires no ano de 1800. São Paulo: Companhia Editora Nacional, 1957 (Coleção Brasiliana no 287).

LOPES, Ana Mônica \& ARNAUT, Luiz. Africa: uma introdução. Belo Horizonte: Crisálida, 2005.

LOVEJOY, Paul E. A escravidão na África: uma história de suas transformações. Rio de Janeiro: Ed. Civilização Brasileira, 2002.

LUZ MARTINS, Lucianne Guedes da. Relações internacionais entre Brasil e Angola: 1808-1840 (Dissertação de Mestrado). Porto Alegre: PPG de História da UFRGS, 2002.

M'BOKOLO, Elikia. África negra - História e civilizações. Tradução de Alfredo Margarido. Lisboa: Editora Vulgata, 2003-2007, 2 vols.

MACKENZIE, J. M. A partilha da África 1880-1900. São Paulo: Ed. Ática, 1994. MADUREIRA, Arnaldo. A colonização portuguesa em África (1890-1910). Lisboa: Livros Horizonte, 1988.

MAESTRI, Mário. História da África negra pré-colonial. Porto Alegre: Mercado Aberto, 1988.

MEDINA, João; HENRIQUES, Isabel Castro. A rota dos escravos. Angola e a rede de comércio negreiro. Lisboa: CEGIA, 1996.

MEILLASSOUX, Claude. Antropologia da escravidão. O ventre de ferro e dinheiro. Rio de Janeiro: Jorge Zahar, 1996.

. Mulheres, celeiros e capitais. Porto: Ed. Afrontamento, 1975.

MELLO E SILVA, Marina de. África e Brasil africano. São Paulo: Ed. Ática, 2006.

MENESES, Solivar Silva. Mamma Angola: sociedade e economia de um país nascente. São Paulo: EDUSP, 1999.

MILLER, Joseph. Poderpolitico e parentesco. Os antigos Estados Mbundu em Angola. Luanda: Arquivo Histórico, 1995.

MANANGA, Kabenguele. Os Basanga de Shaba: um grupo étnico do Zaire. São Paulo: FFLCH-USP, 1986.

NEWITT, Malyn. História de Moçambique. Mem-Martins: Publicações Europa-América, 1997.

NIANI, Djibril Tamsir. Sundjata ou a epopéia mandinga. São Paulo: Ed. Ática, 1982.

OLIC, Nelson Bacic; CANEPA, Beatriz. África, terra e sociedade. São Paulo: Ed. Moderna, 2004. Coleção Polêmica. 
OLIVA, Anderson Ribeiro. Visões da África: leituras e interpretações acerca da religião dos Iorubas, na África Ocidental (Dissertação de Mestrado). Brasília: PPG de História da UNB, 2002.

- Liçoes sobre a África: diálogos entre as representações de africanos no imaginário ocidental e o ensino de História da África no mundo atlântico: 19902005 (Tese de Doutoramento). Brasília: PPG de História da UNB, 2005.

OLIVEIRA, José Carlos de. O comércio do mato: comércio no interior de Angola e Congo. Coimbra: Centro de Estudos Africanos, 2004.

OLIVER, Roland. A experiência africana: da pré-história aos dias atuais. Rio de Janeiro: Zahar, 1994.

PANTOJA, Selma; ROCHA, Maria José (Org.). Rompendo silêncios: História da África nos currículos da educação básica. Brasília: DP Comunicações, 2004.

PANTOJA, Selma (Org.). Entre Áfricas e Brasis. Brasília: Paralelo 15, 2001.

PANTOJA, Selma e SARAIVA, Flávio (Org.). Angola e Brasil nas rotas do Atlântico Sul. Rio de Janeiro: Bertrand Brasil, 1999.

PANTOJA, Selma. Nžinga Mbandi: mulher, guerra e escravidão. Brasília: Thesaurus, 2000.

PARREIRA, Adriano. Economia e sociedade em Angola na época da Rainha Jinga (século XVII). Lisboa: Editorial Estampa, 1989.

PAULME, Denise. As civilizações africanas. Mem-Martins: Publicações Europa-América, 1996.

PELISSIER, René. História da Guiné: portugueses e africanos na Senegâmbia (1841-1936). Lisboa: Ed. Estampa, 1989, 2 vols.

PEREGRINAÇA de André de Faro à terra dos gentios (Guiné). Lisboa: Tipographia Portugal - Brasil, 1945. Coleção "As grandes aventuras e os grandes aventureiros"

PEREIRA, Analúcia Danilevicz. África do Sul e Brasil: dois caminhos para a transição ao pós-Guerra Fria (Tese de Doutorado). Porto Alegre: PPG em História da UFRGS, 2007.

PEREIRA, Francisco José. Apartheid: o horror branco na África do Sul. São Paulo: Brasiliense, 1986.

PRIORE, Mary Del; VENANCIO, Renato Pinto. Ancestrais - Uma introdução à História da África Atlântica. Rio de Janeiro: Ed. Campus, 2004.

READER, John. África. Biografia de um continente. Mem-Martins: Publicações Europa-América, 2002. 
RITA-FERREIRA, António. Fixação portuguesa e história pré-colonial de Moçambique. Lisboa: Instituto de Investigações Científicas Tropicais, 1982.

RODNEY, Walter. Como a Europa subdesenvolven a África. Lisboa: Seara Nova, 1975.

RODRIGUES, João Carlos. Pequena bistória da África negra. Rio de Janeiro: Ed. Globo/Biblioteca Nacional, 1990.

RODRIGUES, Maria da Conceição. O antigo dinheiro em Africa: contribuição para o estudo da cultura material da Idade do Ferro africana: manilhas e cruzetas. Lisboa: FCG, 2002.

SARAIVA, José Flávio Sombra (Org.). O lugar da África. Brasilia: UNB, 1996. . Formação da África Contemporânea. São Paulo: Ed. Atual, 1987.

SILVA, Artur Augusto da. Usos e costumes jurídicos dos Mandingas. Bissau: Centro de estudos da Guiné Portuguesa, s.d.

SERRANO, Carlos Moreira Henrique. Angola: nasce uma nação (Tese de Doutorado em Antropologia). São Paulo: FFLCH-USP, 1988.

TAVARES, Ana Paula; SANTOS, Catarina Madeira. Africae monumenta. A apropriação da escrita pelos africanos. Lisboa: IICT/MCES, 2002.

THORNTON, John. A África es africanos na formação do mundo atlântico: 14001800. Rio de Janeiro: Ed. Campus, 2003.

TURNER, Victor. O processo ritual: estrutura e antiestrutura. Petrópolis: Ed. Vozes, 1976.

UNESCO. História geral da Africa. São Paulo: Ed. Ática/UNESCO, 19811991, 4 vols.

VISENTINI, Paulo; RIBEIRO, Luiz Dario; PEREIRA, Analúcia Danilevicz. Breve História da Africa. Porto Alegre: Leitura XXI, 2007.

VITORIANO, José Manuel. História da Africa Ocidental. Lisboa: Instituto Superior de Ciências Sociais e Políticas, 1998.

WALDMAN, Maurício; SERRANO, Carlos. Memória d’África: a temática africana em sala de aula. São Paulo: Ed. Cortez, 2007. 


\section{Recursos Eletrônicos ${ }^{1}$}

BCEA - BIBLIOTECA CENTRAL DE ESTUDOS AFRICANOS http:/ /bcea.iscte.pt/

CASA DAS ÁFRICAS: ESPAÇO CULTURAL E DE ESTUDOS SOBRE SOCIEDADES AFRICANAS, www.casadasafricas.org.br

CEA (CENTRO DE ESTUDOS AFRICANOS) - Universidade de São Paulo, www.fflch.usp.br/cea/af_revista.html

MEMÓRIA DE ÁFRICA (Fundação Portugal/África) - Universidade de Aveiro, http://memoria-africa.ua.pt

REVISTA - AFRICANA STUDIA (CEAUP - Centro de Estudos Africanos) - Universidade do Porto, http://www.africanos.eu/ceaup

REVISTA - AFRO-ÁSIA (CENTRO DE ESTUDOS AFRO-ASIÁTICOS) - Universidade Federal da Bahia, www.afroasia.ufba.br

REVISTA - ESTUDOS AFRO-ASIÁTICOS (Universidade Cândido Mendes, RJ), www.scielo.br/eaa

AFRICA SOUTH OF THE SAHARE SELECTED INTERNET RESOURCES) - African Studies Association, USA) www-sul.stanford.edu/ depts/ssrg/africa/guide

AFRIKARA: REGARDS ALTERNATIFS SUR LE MONDE D'HIER, D'AUJOURD'HUI ET DE DEMAIN, http://www.afrikara.com/index.php AFRIQUE \& HISTOIRE (Editions Verdier, Paris), http:/ /www.cairn.info/ revue-afrique-et-histoire.htm

CAHIERS D’ÉTUDES AFRICAINES (Ecoles des Hautes Études en Sciences Sociales), www.persee.fr

CLIO EN AFRIQUE:Bulletin d'anthropologie et d'histoire africaines en langue française (Université de Provence), http://sites.univ-provence.fr/ $\sim$ wclio-af

HISTOIRE DE L'AFRIQUE DE L'OUEST, http:/ /www.histoire-afrique.org INTERNET AFRICAN HISTORY SOURCEBOOK (Fordham University), www.fordham.edu/halsall/africa/africasbook.html

JOURNAL DES AFRICANISTES (Université de Paris), www.persee.fr

${ }^{1}$ disponíveis em 21/04/2008 
JOURNAL OF AFRICAN ARCHAEOLOGY (University Frankfurt), http://www.african-archaeology.de

JOURNAL OF AFRICAN HISTORY (University of Cambrige), http:// www.periodicos.capes.gov.br

MALD - MUTATIONS AFRICAINES DANS LA LONGUE DURÉE

(Université de Paris), http://mald.univ-paris1.fr

SUDANIC AFRICA: A JOURNAL OF HISTORICAL SOURCES (Centre for Middle Eastern Studies, University of Bergen), www.uib.no/hff/smi/sa

\section{Documentários}

África: uma história rejeitada (EUA) Escrito, produzido e dirigido por David Dugan, 1995 (Time-Life - Abril Coleções) (VHS).

Atlântico Negro: na rota dos Orixás (Brasil). Direção de Renato Barbieri, 1998. Contos cruéis de guerra (Contes cruels de la guerre) (França, Congo). Direção de Ibea Atondi \& Karim Miské, 2002.

Eu, um negro (Moi, un noir) (França). Direção de Jean Rouch, 1958 (Distr. Vídeo Filmes).

Família Alcântara (Brasil). Direção de Daniel Sola Santiago \& Lílian Sola Santiago, 2006 (Distr. Versátil).

Férias em casa (Vacances au pays) (França, Camarões). Direção de Jean-Marie Teno, 2000.

Jaguar. Direção de Jean Rouch, 1967 (Distr. Vídeo Filmes).

Mestres loucos, Os (Les maitres fous) (França). Direção de Jean Rouch, 1955 (Distr. Vídeo Filmes).

Trèsors de l'Afrique, Les (Les trèsors de l'humanité). Direção de Mark Verkerk \& Jean Pieter Saflev, 1998 (TV 5, France). 


\section{Filmes}

Africa Addio (Itália). Direção de Gualtiero Jacopetti \& Franco Prosperi, 1966. Africa minha (EUA). Direção de Sydney Pollac, 1985

Árvore dos antepassados, A (Moçambique). Direção de Licínio Avevedo, 1995. Assassinato sob custódia (A dry white season) (EUA). Direção de Euzhan Palcy, 1989.

Aventura na Africa, Uma (The African Queen). Direção de John Huston, 1951 (Distr. Continental Home Vídeo).

Aventuras de Azur e Asmar, As (França). Direção de Michel Ocelot, 2007 (Videofilmes).

Bamako (Mali). Direção de Abderrahmane Sissako, 2006.

Batalha de Argel, A (Argélia, Itália). Direção de Gillo Pontecorvo, 1966 (Videofilmes).

Bopha: à flor da pele (EUA). Direção de Morgan Freeman, 1993 (Paramount). Câmera de madeira, A (The wooden camera) (França, EUA, África do Sul). Direção de Ntshaveni Wa Luruli, 2003.

Céu que nos protege, $O$ (The sheltering sky) (Itália, Inglaterra, EUA). Direção de Bernardo Bertolucci, 1990 (Editora NBO)

Cobra Verde (Alemanha). Direção de Werner Herzog, 1987 (Distribuição New Line Home Vídeo).

Deserdados, Os (Cry, the beloved country) (EUA). Direção de Darrel Roodt, 1995.

Deserdados, Os (Cry, the beloved country) (Inglaterra). Direção de Zoltan Korda, 1951.

Deuses devem estar loucos, Os (Botswana). Direção de Jamie Uys, 1981 (Argovídeo).

Diamante de sangue. Direção de Edward Zwick, 2006 (Warner Bross).

E a luz se fez (Et la lumière fut) (França, Alemanha, Itália). Direção de Otar Iosseliani, 1990.

Grito de liberdade, Um (Cry freedom) (EUA, Inglaterra). Direção de Richard Attenborough, 1987 (Distr. Universal Home Vídeo). 
Herói do nosso tempo, Um (França, Israel). Direção de Radu Mihaileanu, 2004 (Distr.Art Filmes).

Hotel Ruanda (EUA). Direção de Terry George, 2004 (Distr. United Artists). Infância roubada (Totsi) (Inglaterra, África do Sul). Direção de Gavin Hood, 2005 (Distr. Castello Lopes).

Jobman: fúria silenciosa (EUA). Direção de Darrel Roodt, 1990 (Distr. Paris Filmes).

Keita. L’heritage du griot (Burkina Fasso). Direção de Dani Kouyaté, 1994.

Kiriku e a feiticeira (França). Direção de Michel Ocelot, 1999 (Distr. Paulinas Multimídia).

Leão de sete cabeças, O (Itália). Direção de Glauber Rocha, 1970 (Distr. Polifilm).

Lugar nenhum na África (Alemanha). Direção de Caroline Link, 2001 (Distr. Califórnia).

Montanhas da lua, As (EUA). Direção de Bob Rafelson, 1990 (Distr. LK-Tel)

Nha Fala (França, Portugal, Guiné Bissau). Direção de Flora Gomes, 2002.

Preço do perdão, O (Le prix du pardon) (França, Senegal). Direção de Manour Soranade, 2001.

Ruas de Casablanca, As (Ali Zaoua, prince de la rue) (Marrocos). Direção de Nabil Ayouch, 2000 (Distr. Europa Filmes).

Sarafina. O som da liberdade. Direção de Darrel Roodt, 1993.

Sia. Le rêve du python (Burkina Fasso). Direção de Dani Koyaté, 2001.

Silêncios do palácio, Os (Les silences du palais) (França, Tunísia). Direção de Moufida Tiatli, 1994.

Sombra e a escuridão, A (EUA). Mens Hopkins, 1996 (Distr. Paramount).

Tempo de espera (La saison des hommes) (Tunísia, França). Direção de Moufida Tiatli, 2000 (Distr. Grupo Estação).

Último rei da Escócia, O (Inglaterra). Direção de Kevin Macdonald, 2006 (Distr. Fox)

Zulu (Inglaterra). Direção de Cy Endfield, 1964. 


\section{AUTORES}

Analúcia Danilevicz Pereira - Doutora em História pela Universidade Federal do Rio Grande do Sul. Professora da Faculdade PortoAlegrense.

Anderson Ribeiro Oliva - Doutor em História pela Universidade de Brasília. Professor na Universidade Federal do Recôncavo da Bahia.

André Luiz Reis da Silva - Doutor em Ciência Política pela Universidade Federal do Rio Grande do Sul. Professor da Faculdade Porto Alegrense.

Bárbara Macagnan Lopes - Graduanda em Historia pela Universidade Federal do Rio Grande do Sul.

Diego Schwalb Zanoto - Graduando em Historia pela Universidade Federal do Rio Grande do Sul.

Diego Souza Marques - Graduando em Historia pela Universidade Federal do Rio Grande do Sul.

Eder da Silveira - Doutor em História pela Universidade Federal do Rio Grande do Sul. Professor do Centro Universitário Metodista - IPA.

Felippe Jorge Kopanakis Pacheco - Mestre em Geografia pela Universidade Federal de Goiás. Convidado do Centro Interdisciplinar de Estudos África-Américas da Universidade Estadual de Goiás.

Jorge Euzébio Assumpção - Mestre em História pela Pontifícia Universidade Católica do Rio Grande do Sul. Professor no Curso de Pós-Graduação da Faculdade Porto-Alegrense e professor da Secretaria Estadual de Educação do Rio Grande do Sul.

José Antônio dos Santos - Doutorando em História na Pontifícia Universidade Católica do Rio Grande do Sul. Professor no Curso de Pós-Graduação da Faculdade Porto-Alegrense. 
José Rivair Macedo - Doutor em História Social pela Universidade de São Paulo. Professor Associado no Departamento de História da Universidade Federal do Rio Grande do Sul.

Joveta Jose - Doutorando em Ciência Política na Universidade Federal do Rio Grande do Sul. Professor do Centro Universitário Metodista - IPA.

Leonardo Veiga Guarnieri - Graduando em História pela Universidade Federal do Rio Grande do Sul.

Marisa Antunes Laureano - Mestre em História pela Pontifícia Universidade Católica do Rio Grande do Sul. Professora da Rede Estadual de Ensino do Rio Grande do Sul.

Paulo Gilberto Fagundes Visentini - Doutor em História Econômica pela Universidade de São Paulo. Professor titular de Relações Internacionais da Universidade Federal do Rio Grande do Sul.

Sílvio Marcus de Souza Correa - Doutor em Sociologia pela Westfälische-Wilhelms-Universität Münster. Professor da Universidade de Santa Cruz do Sul.

Tania Maria Seggiaro Chagastelles - Especialista em História Contemporânea pela Universidade do Vale do Rio dos Sinos. Professora da Faculdade Porto-Alegrense. 


\section{Série Diversidades}

A série Diversidades apresenta estudos e experiências no campo da educação na diversidade sociocultural que articulam a extensão universitária ao ensino e à pesquisa, fortalecendo o compromisso institucional com as políticas de promoção social e possibilitando o acesso a obras relevantes para os diferentes segmentos sociais.

\section{Etnicidade, Identidade e Territorialidade}

A linha editorial constitui-se num espaço para a edição, publicação e divulgação da produção de estudos e pesquisas com os temas etnicidade, identidade e territorialidade, consolidando resultados de ações que articulam a extensão ao ensino e à pesquisa, fortalecendo o compromisso interinstitucional e com as políticas de promoção social, possibilitando o acesso de obras relevantes para os diferentes segmentos da sociedade. Ao propor e organizar esta linha editorial, a Pró-Reitoria de Extensão da UFRGS, através do seu Departamento de Educação e Desenvolvimento Social, consolida suas parcerias com a Editora da UFRGS, com o poder público e com a sociedade civil organizada.

\section{Comissão Editorial}

Sara Viola Rodrigues (Pró-Reitora de Extensão - PROREXT/UFRGS), Susana Cardoso (Vice-Pró-Reitora de Extensão e Diretora do DEDS/PROREXT/UFRGS), Ana Lúcia Liberato Tettamanzy (Coordenadora Pedagógica do Programa Conexões de Saberes: diálogos entre a universidade e as comunidades populares/UFRGS), Rita de Cássia dos Santos Camisolão (DEDS/PROREXT/UFRGS, Coordenadora do Programa Educação Anti-Racista no Cotidiano Escolar e Acadêmico).

\section{Títulos Publicados}

Tramando falas e olhares, compartilhando

saberes: contribuições para uma educação

anti-racista no cotidiano escolar

José Antônio dos Santos

Véra Neusa Lopes

Rita de Cássia dos Santos Camisolão (Orgs.)

\section{Desvendando a história da África \\ José Rivair Macedo (Org.)}

Por uma política de ações afirmativas:

problematizações do programa conexões de

saberes - UFRGS

Ana Lúcia Liberato Tettamanzy

Maria Aparecida Bergamaschi

Nair Silveira

Rafael Arenhaldt

Susana Cardoso (Orgs.) 
Pré-impressão, impressão e acabamento:

Editora Evangraf

Rua Waldomiro Schapke, 77 - Porto Alegre, RS

Fones (51) 3336-0422 e 3336-2466

evangraf@terra.com.br

Editora da UFRGS • Ramiro Barcelos, 2500 - Porto Alegre, RS - 90035-003 - Fone/fax (51) 3308-5645 www.editora.ufrgs.br - www.livraria.ufrgs.br • Direção: Sara Viola Rodrigues $\bullet$ Editoração: Paulo Antonio da Silveira (coordenador), Carla M. Luzzatto, Fernanda Kautzmann, Luciane Delani, Maria da Glória Almeida dos Santos e Rosangela de Mello; suporte editorial: Fabiana Ferracini (bolsista), Gabriela Carvalho Pinto, Priscila Novak (bolsista) e Tales Gubes Vaz (bolsista) • Administração: Najára Machado (coordenadora), Angela Bittencourt e Laerte Balbinot Dias; suporte administrativo: Janer Bittencourt • Apoio: Idalina Louzada e Laércio Fontoura. 